\title{
APPLE GROWING in the PACIFIC NORTHWEST
}

t: 

की सो
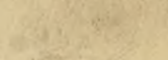

ind

$3+86$

(20) $x^{2}=$ 



\section{Apple Growing in the Pacific Northwest}

A Condensation of Lectures, Experiments and Discussions ? Conducted by the Educational Department OF THE

Portland, Oregon, Young Men's Christian Association 


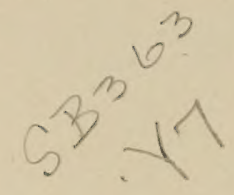

Copyrighted 1911

By

Portland, Oregon

Young Men's Christian Association

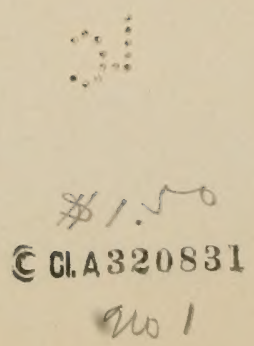




\section{Contents}

Page

Selection of Orchard Soils........... C. I. Lewis........ 7

First Year in the Apple Orchard.......... W. Sparks....... 17

First Things in Apple Culture......... Chas. A. Cole........ 29

Management of Orchard Soils.......... C. Thom........ 41

Varieties and Environment........... C. I. Lewis......... 49

Building an Apple Tree.............. A. I. Mason......... 69

Development of Apple Trees...........W. S. Thornber...... 82

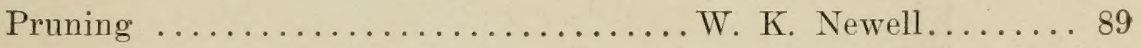

Pcllinizing ...................... J. Krause.........100

The Best in Apple Culture.............. M. Williamson.....108

Apple Tree Anthracnose............... S. Jackson........118

Injurious Orchard Insects............ Hailey F. Wilson.....126

The Codling Moth................ B. Cordley........136

Apple Scab and Crown Gall............. S. Jackson.........146

Poultry in an Apple Orchard............. L. Blanchard......156

Packing Apples ........................... Chas . Cole....

Organization for Marketing Apples.......H. C. Atwell...........184

The Process of Charpitting............H. W. Sparks......... 197

The Small Farm and How to Make It Pay. . James Withyecmbe ... . 207 


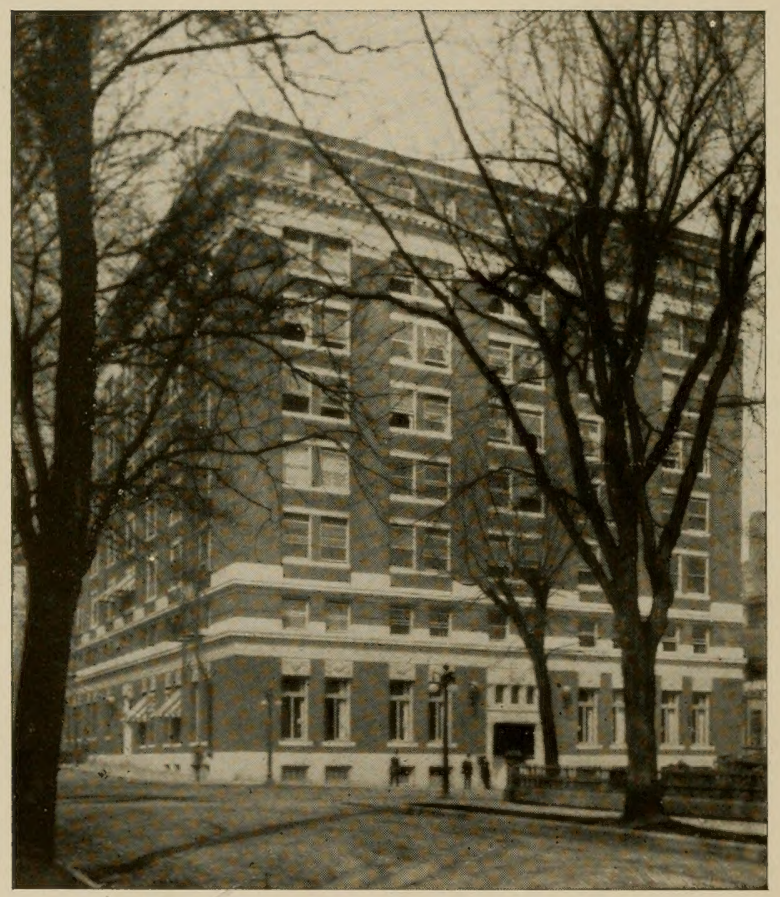

Portland, Oregon

Young Men's Christian Association

Building in which the Lectures, Experiments and Discussions recorded in this book were conducted. 


\section{Preface}

"Apple Growing in the Pacific Northwest" is the condeusation of two years' work of the Educational Department of the Portland Young Men's Christian Association carried on under the name of the "Y. M. C. A. Apple Culture Club."

These lectures are by the professors of the Washington and Oregon Agricultural Colleges, as well as practical apple growers and leading experts in the Pacific Northwest. We believe this means the leading authorities on apple culture in the world.

A feature of special interest in this book to those who are or expect to be engaged in the apple-growing business, will be the questions and answers at the close of each chapter. These are actual questions and real answer's stenographically recorded during the discussions following the lectures.

The lectures were attended by from two to four hundred apple enthusiasts every Saturday night.

These lectures are placed in this book form by the Portland Association for the purpose of placing in a permanent record this valuable store of expert information in respect to one of the rapidly growing industries of the Northwest.

The Portland Association has taken a deep interest in the industrial and agricultural life of this section. Schools in Plumbing, Automobile, Mining and Assaying, Pharmacy, Carpentry and Electricity, as well as some fifty other commercial and industrial subjects are conducted. Large contests have been promoted in poultry and potato growing.

This book is simply another effort on the part of the Association to help in the constructive development of the Pacific Northwest.
W. M. Ladd, President.
H. W. Stone, General Secretary.
R. C. French, Educational Secretary. 


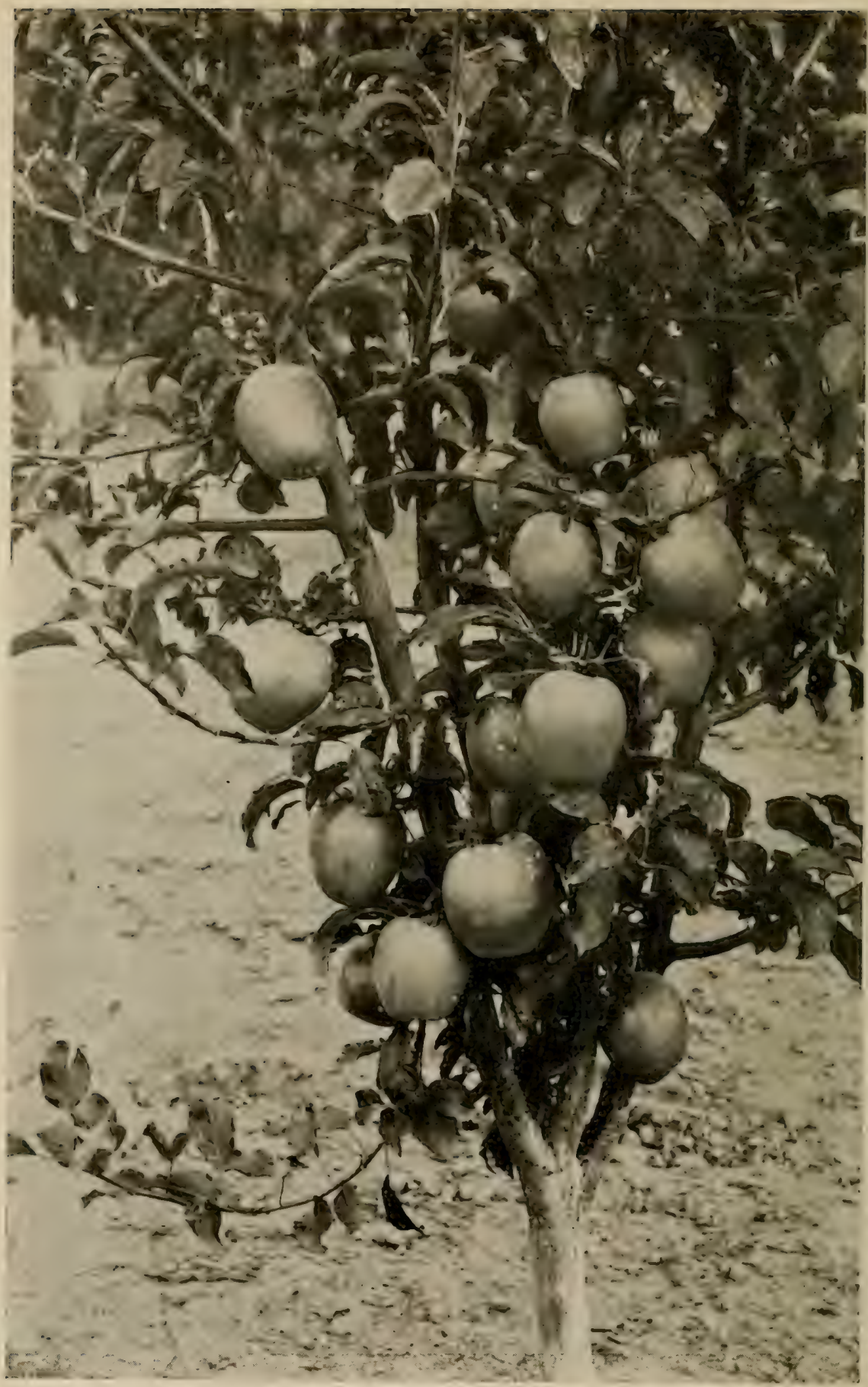

A famous four-year-old Ortley Apple tree, Hood River Valley, Orezon. The photograph from which this engraving was made attracted unusual attention on account of the size, age of the tree and perfection of the apples. 


\section{Selection of Orchard Soils}

By C. I. Lewis, of the Oregon Agricultural College.

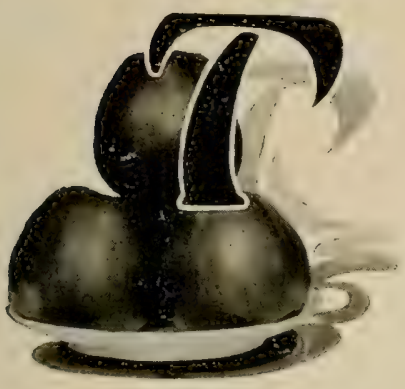

HE subject of my lecture is, "Orchard Soils, Their Selection, Tillage and Fertility." I want to take you first over Western Oregon Soils, taking the Cascade Mountains as the dividing line. All of Eastern Oregon is voleanic ash soil. It runs from sand to coarse gravel and the alluvial soils.

The Grand Ronde Valley is in a state of alluvial soil, which is very fertile. Under these conditions, one will have the most success after a very rainy season. Freewater. near Walla Walla Valley, has about as much fruit land as the Hood River Valley, but because there have been only small orchards there with about fifteen or twenty varieties in one orchard, we have not heard so much of it. The greater part of the soil is volcanic ash, which is very sandy and is excellent for pears and peaches. Now comes the Umatilla Valley. We have an experimental station there and find that the soil will grow pears better than any other soil. The Dalles Valley grows peaches and grapes, and it may grow good apples, but the best fruits to grow on this soil are peaches and grapes, because there are only about seven inches of rainfall there. In Eastern Oregon there is water to irrigate with, a condition unlike that of Western Oregon. One can grow peaches, cherries, apples and pears on the same soil under irrigation. Of course, there are a very few men that ean make a success of growing so many different fruits on the same piece of land for the reason that pears need irrigating at a different time from apples, and the same way with the others; they all need irrigating at different times, so it is a hard proposition to grow the different fruits on the same piece of irrigated land, and $I$ do not think it will very likely be done, although one may get some very good results. Taking the Hood River Valley into consideration, there are about seven types of soil: gravel loam, typical volcanic ash, etc.

Now we come to the Willamette Valley. It covers an area of 160 miles one way and from 35 to 60 miles the other way, with an eleration 
of 100 feet up to snow line. We will begin at the lowest point and work up. This lowest part is known as the river bench soil. Some of these soils are the richest in Oregon, being deepest near the river. They are, as a whole, ideal peach soils, and grow the best peaches in the Northwest. I do not know why more peaches are not raised here: there is no reason for not doing so. The early frosts do not hurt peaches as they do apples. There is an orchard in this valley 20 years of age, and the owner told me that he got three crops in five years, which is considered very good. The soil is a silver sand loam, which is known to be very excellent, especially, as I have said, for peaches. Apples may not do as well because they are subject to the early frosts, but some of this may develop into very fine apple and pear soil in time. Some of the finest bearing trees have been found on this silver sand loam and some splendid Yellow Newtown orehards are also to be found there. One thing you want to be careful of when you select your soil, and that is the sudden drop from high to low elevation. Where you find these drops, you may be pretty sure of frost. The Comice pears do very well there. These pears come into bearing late, and are very shy bearers, but do excellently well in the Willamette Valley. Of course, these are also subject to frost. A frost in April would be detrimental to the apple and pear, while it would not hurt the peach. That is what makes it better peach land, or at least, is one of the reasons.

Then there is what is ordinarily known as the White Land, which include parts of Linn, Marion and Benton Counties. The soil is rather white in color and is therefore known as the White Land. This soil is generally very deep and has good drainage. There is no reason why it should not be good fruit land, because around the farm houses one will find fruit trees which seem to do very well. This may be on account of the building changing the drainage, or generally giving the soil a better drainage. These soils as a rule are very deep; I remember making one boring with a one-half inch auger and went down 15 feet and still found good soil. This soil is strong in character, but would have to be greatly improved for fruitgrowing. It is generally considered to be free from frosts.

Next comes the clay loam, which is just above the white land. These clay lands constitute the rolling lands of the valley. They are the prime fruit lands of the valley, judging from the orchards growing on the soil. The best orchards so far have come from these soils.

Then come the hill lands or the red lands. There are several kinds of red lands of which some may grow nothing, while others are some of the very best. Some of the richest lands we have in the State are red lands. There are the foothills and the table lands. The foothills are considered especially good on the south and west sides. If one wants to 
be sure he has a good deep soil; get a four-foot auger and bore a hole in the ground, and if one can go four feet, it will be deep enough. Sometimes even the north and east side of the same hills are very rich. This is very true of the foothills of the Coast Range Mountains. There are thousands and thousands of acres of rolling land which would make typical orchards. Of course, with good soil, one wants to get all the other conditions. Good soil alone will not make a good orchard.

Next we have the Umpqua Valley. The bottom lands are known as being splendid apple and pear lands. The soil is alluvial here.

One may get the best soil in Oregon and then make a failure of growing apples. All things should be taken into consideration-all the necessary conditions. One wants to see that he has good loam, good soil, drainage, sufficient depth, and see that it is not subject to strong winds. One wants to choose a location where he will not get all the east winds for his orehard, but probably the most important thing is the depth. The soil should also have plenty of nitrogen, but that may be easily supplied, and the common Oregon vetch is very good for that. Therefore, if one has vetch he can always have nitrogen. It is one thing to choose land that will grow any tree, and another thing to grow trees that will bear for 20 to 30 years. Trees can be grown on five or six inches of soil, but they will last or bear only about five, six or seven years. It is easier to grow fruit on shallow soil where it is irrigated than where it is unirrigated, because the irrigation always supplies the fruit with water and if unirrigated soil is shallow it will dry out very quickly.

The way to find whether one has depth or not is to get a common auger and bore holes all over the ground. Four feet is generally known to be deep enough, while three feet might do. In going over the land one must look for a drop; if there is any rock you will find it there. Of course, we need not expect to find the same depth all over the place because sometimes there is a difference of a few feet and one must always expect to find some parts of a tract of land which he cannot use. Besides looking for good depth one wants to get land that has good air and soil drainage. Land that is generally rolling is mostly well drained. That is one point to remember. One of the most common stones that one strikes in looking for depth in Oregon is soapstone. Do not get land that has soapstone near the surface. Sometimes this soapstone is well disintegrated, in which case the roots will penetrate it, but more often it is not. so one wants to look out for soapstone.

Different kinds of apples and pears take different kinds of soil. Pears will generally thrive on lighter soils than apples. The Winter Nellis pears require the deepest and richest of soil. The Spitzenberg apple requires more attention than any other apple and probably does 


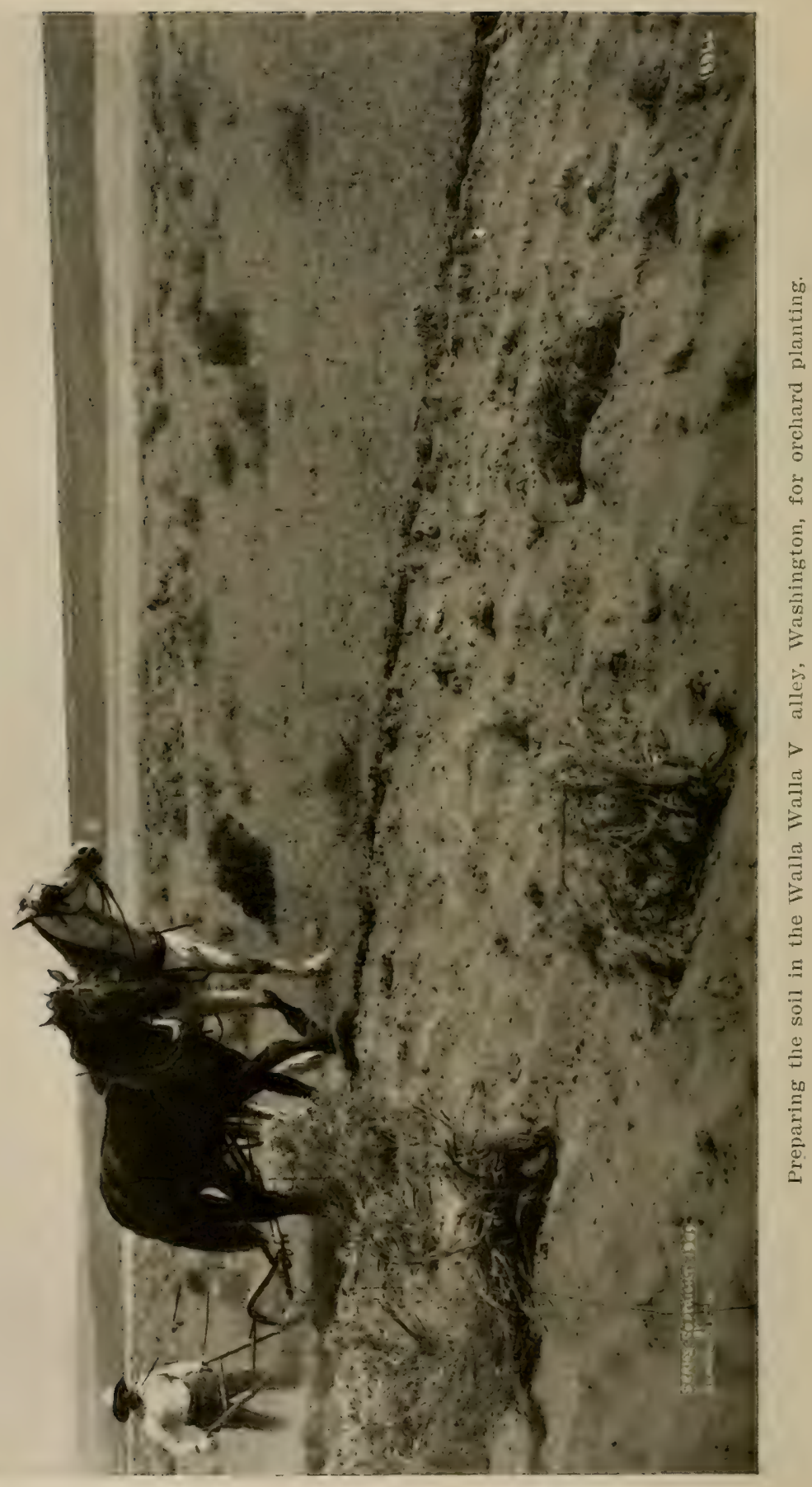


best on very heavy soil, such as clay sand loam. If one is going to plant a Spitzenberg apple orchard he will have to make up his mind beforehand to live with his trees, hecause they need more petting and attention than any other apple, not only when they are young, but all through their life. The more one fondles and pets them the better trees he will have. The Northern Spy is an apple that should not be grown on the very heaviest of soils. In fact, the lighter the soil the better the apple. If put in heavy soil it grows very rank and comes in bearing very late. If put in lighter soil it grows better, that is, it spreads out and comes into bearing earlier, and it is more tender and has a better color. It is one of the best apples in Oregon if grown right.

Another thing that one wants to be very careful about is very good drainage, insuring a less amount of moisture and frosts. I want to call your attention to the lands on the side of the foothills. You will mostly find them well drained. I want you to understand thai when I say good drainage, I do not mean land that never has any water on it. One will find some prime apple and pear lands that are under water all winter. This is especially true in parts of Oregon where we have three or four months of winter rain, but that water must be removed very regularly in the early Spring or as soon as possible. Some of the best lands in Oregon are of that type:

\section{Where Trees Can Be Grown.}

Another point to be looked out for is seepage water. You will find it mostly on the sides of the hills. I have come across a number of soils that from outward appearances look all right, but when I went in a short distance I found that the ground was soaked. I remember one instance where a man had a well 27 feet deep that had about 17 feet of water in Angust. Another place we went seven feet and had between three and four feet of water, and I have struck water at three and one-half feet. This water comes from the hills and seeps down through the ground and keeps the roots cool. Trees will not grow well under these conditions. It is not always at the top of the soil; sometimes it is down four or five feet.

How should soil be used to get the best results? The first thing is to work the soil deep, thus forming a reservoir which keeps the winter moisture in it. A good method for doing this is clean culture. It means good plowing, deep harrowing in spring until it is in a good condition, then in the summer months go over it again and again with some shallow instrument until the soil is like dust. In this way the moisture will be retained. For example: take a plank, even in sum- 
mer time when it is hot, under that plank cne will find that the ground is a little moist; that is the way it is with the orchard soil. The more one works it the finer it gets, and it acts as the plank does on the soil beneath, thereby lieeping it moist.

In winter the soil is supplied with water, maybe three or four times what it needs, and there must be a way to keep part of the water in the soil for the time of the year when it will be needed. It should not go out into the atmosphere unless it goes out through the plant. I have had people tell me that they worked their orchard 12 and 18 times in one summer and made a success of it, so no matter how many times one has to work it he must do so until he is sure he is going to hold the moisture. Get a good implement to work with. Don't get something that is not practicable.

One of the best results of good cultivation is the size of the apple. If one does not work the soil and it is dried cut before the first of August, his apples are bound to be small and irregular in size. Besides that, there is the difference of color. If one has not necessary moisture when he wants it his apples are apt to be dull in color and not bright as they ought to be. Furthermore, the fruit will not have the form it would have otherwise; keep that reservoir for the summer suppiy. The three essential reasons for so doing are: first, size; secone, form; and, third, color.

Now another mistake that so many people make is that they till their orchard for the first two or three years, until it gets well started, and when the trees need it most neglect it, and then they are surprised because they did not make it a success.

Another trouble is that most people cultivate their orchards too long, or keep up the tillage too long-too late in the season. Their orchard ought to be sufficiently cultivated by August 1 every year. It should have been eultivated at least three or four times by the middle of August at the latest. Some people cultivate their orchards until October, which is entirely too long. In some soils one should do just the opposite. That is true of the sandy soil or voleanic ash soils. The clay and heavy soils have to be plowed and harrowed over and over until they are fine, but the sandy soils are already fine and do not need so much eultivation. Be sure to get the right kind of an instrument to work with. I have seen people use an implement which required five or six horses, whereas a man with a harrow or a roller could have done much better. Many people use the clod masher, which I believe is very good-probably the best I have ever seen. Make it in two sections and in that way it will not only mash the lumps in the ground, but will make the ground fine, even and smooth, as it should be. 
I will next take up diversified farming. If a man has 20 or 30 acres of land in orchard, it will take much work to attend to it properly. When plowing time comes, do not plit off plowing a week or ten days. So it is with pruning and spraying; it has to be done at the right time. When a man has all his farming to do, he will be bound to have everything come at nnce and will have to postpone something and is likely not to make a success of anything. Do not try to do orcharding and farming at the same time. Of course the one advantage is that one has the fertilizer, but if he wants it he ean buy it. As that would be too expensive for most of us some other way must be found, and that way is by cover crops. These cover crops should be put in early, in the fall and should grow all winter and be plowed under as soon as the sap begins to come in the spring. Now remember, I did not say to cut off and feed to the cows in the spring. Plow under in the spring. This will make better tillage possible and help the soil hold moisture, and the main point is that it makes the soil richer. It will furnish plant food and nitrogen which the trees need.

We have tried experiments as to what will do best for this cover crop and have now practically decided between the hairy vetch and the Oregon vetch and rye. I believe the Oregon vetch and rye is all one will want. Do not get it in any later than the last of August or the first of September. I did not say the first of October. Use the ordinary seeder for putting it in before the first rain comes, so that it will get a good start right away. The higher it gets the better it will be. Put in about 40 pounds of vetch seed and 10 pounds of rye seed to the acre. The land should not be plowed in the fall. Plow just as soon as the sap begins to come in the spring. If one uses this cover crop he will not need very much fertilizer, if any, for his trees will then make a strong, healthy growth. There are very few orchards that are not benefited by cover crops. The two I have spoken of can be recommended for western Oregon. Vetch makes most land very rich, and that is why it is so good for a cover crop. In some places they use the cowhorn turnip, and rape. Use about 20 pounds of the rape and 10 pounds of turnip per acre. This takes up the potash and makes it beneficial to the plant. They take nothing from the air, but simply take up the potash, conveying it into such form as will make the trees strong and sturdy.

Now just a little about fertilizers. I believe that when the time comes for the crops, if by investing $\$ 10$ one can save 8 or 10 per cent he will do so. Consider the sort of fertilizer your land needs. If something is put on which the land does not need, it may do more harm than goorl. Make the experiment yourself. Take three blocks 


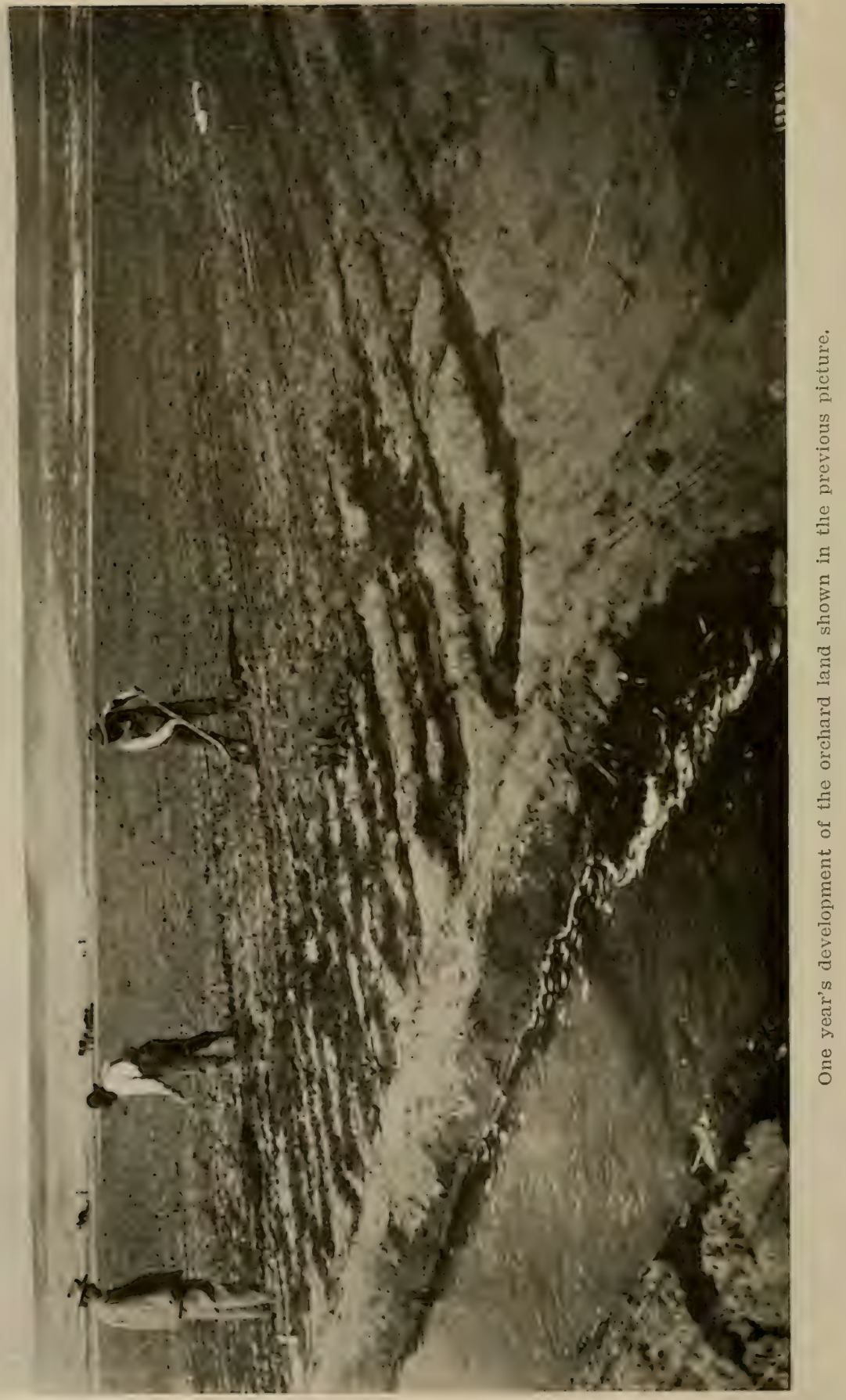


on the first one put phosphorous, on another put potash, and on the third put both together. In this way one will know just what his sil needs and can apply it to the trees.

\section{Questions and Answers.}

Q. Why do you put the rye in the cover crop?

A. To help hold the veteh up. Ten pounds of rye to the 40 pounds of veteh is all you will need.

Q. How can one determine the depth of the soil?

A. I would take a four-foot augur and make a boring of four feet at least. In some places the soil simply changes color and in others you will strike rock or soapstone or cement gravel or some other form. If you bore four feet and find the same kind of soil for that depth it will be all you want.

Q. How are you going to tell if it is good for growing trees?

A. If vegetables and wheat grow well the land is likely to be good for apples. You can tell a little from some old trees on the land. Where you find fir trees you will usually have good land.

Q. Does land plaster make a good fertilizer?

A. I would hardly recommend land plaster. It is like giving whiskey to a boy. It stimulates the trees.

Q. In the different soils would you advise any difference in the distance of the trees?

A. Well, not harldy, but in the heary soils you might plant them a little closer than in the other.

Q. What variety of pears would you recommend for the Willamette Valley?

A. Bartlett, Comice, Anjon and Winter Nellis pears would all do well, I believe.

Q. What distance apart would you plant the trees?

A. About 30 feet.

Q. How would pears do near Estacada?

A. I see no reason why they should not do well.

Q. What do you think of the Greening?

A. The Greening does not do nearly as well here as in the Eastern States. They can ship better Greenings here than we can grow.

Q. How is the Russet?

A. There are so few trees here, that I can tell nothing about them.

Q. What do you think of the dwarf pear as a commercial pear?

A. I think it will be in great demand before long and there is no reason why an orchard should not be valuable. 
Q. What kind of crop would you put on land just grubbed off to grow until the spring of 1912 ?

A. I would grow potatoes or other vegetables.

Q. Would you raise corn on that land?

A. I would not advise you to raise corn.

Q. Would you advise putting in any crops at all on new land just grubbed?

A. No, I believe I would not. Still we always do, but when we put out our experimental orchards we always put a crop in. We even have an orchard where the stumps are not all out yet. Just take out enough stumps to plant the trees and take the remaining stumps out as you go.

Q. What is the character of the soil on the Sheridan hills?

A. It is mostly red clay loam.

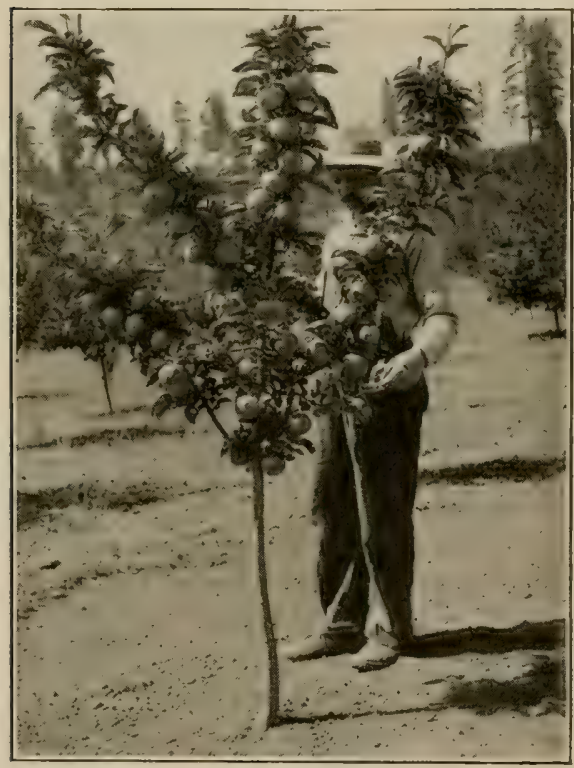

A four-year-old Ortley. 


\section{First Year in the Apple Orchard}

H. W. Sparks, of the Washington State College.

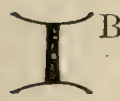

BELIEVE that the principal factor in successful horticulture is the man himself. I would tell any one if he does not like the business sufficiently to give it his undivided attention, not to attempt it. One can fail in that business as well as in any other. There is nothing in the art of raising fruit that is difficult to learn, but like everything else of that kind, it requires special attention.

The next factor is to find a location where the soil, climatic conditions, market conditions and transportation facilities are right. These are all important factors. One of the first requirements of the soil is that it is well-drained. The location should be a little higher than the surrounding country. Low places are inclined to be frosty. There are other conditions beside elevation that make the difference between a frosty, underisable place and one desirable. Sometimes low places are situated near a body of water that keeps off the frosts, and sometimes air currents come through mountain passes. Go out over the land where you are considering planting an orchard on a frosty morning and see if the frost is heavy. I do not think the difference in soils is known as it should be; but, as a rule, avoid heavy, low soils. These black, humid soils are inclined to produce too much wood growth. The volcanic-ash soils are the best. There are tracts of this soil throughout this state and Washington. Sandy loam soils are sometimes very good, but there is such a difference in the soils that it is hard to say generally which is best. In all these matters one should be governed largely hy his surroundings. If one has an orehard that is doing well and seems to be in a healthy condition, he can rest assured that the soil is good in that locality.

\section{Proximity to Market.}

The next consideration is proximity to market. One can be located too far from transportation, and often the difference of a few cents makes the difference between suceess and failure in fruit-growing. That rule cannot be applied too strictly, because districts that are removed today, in three, four or five years from now may not be. What might not he valuable for orehard-planting now in four or fire 


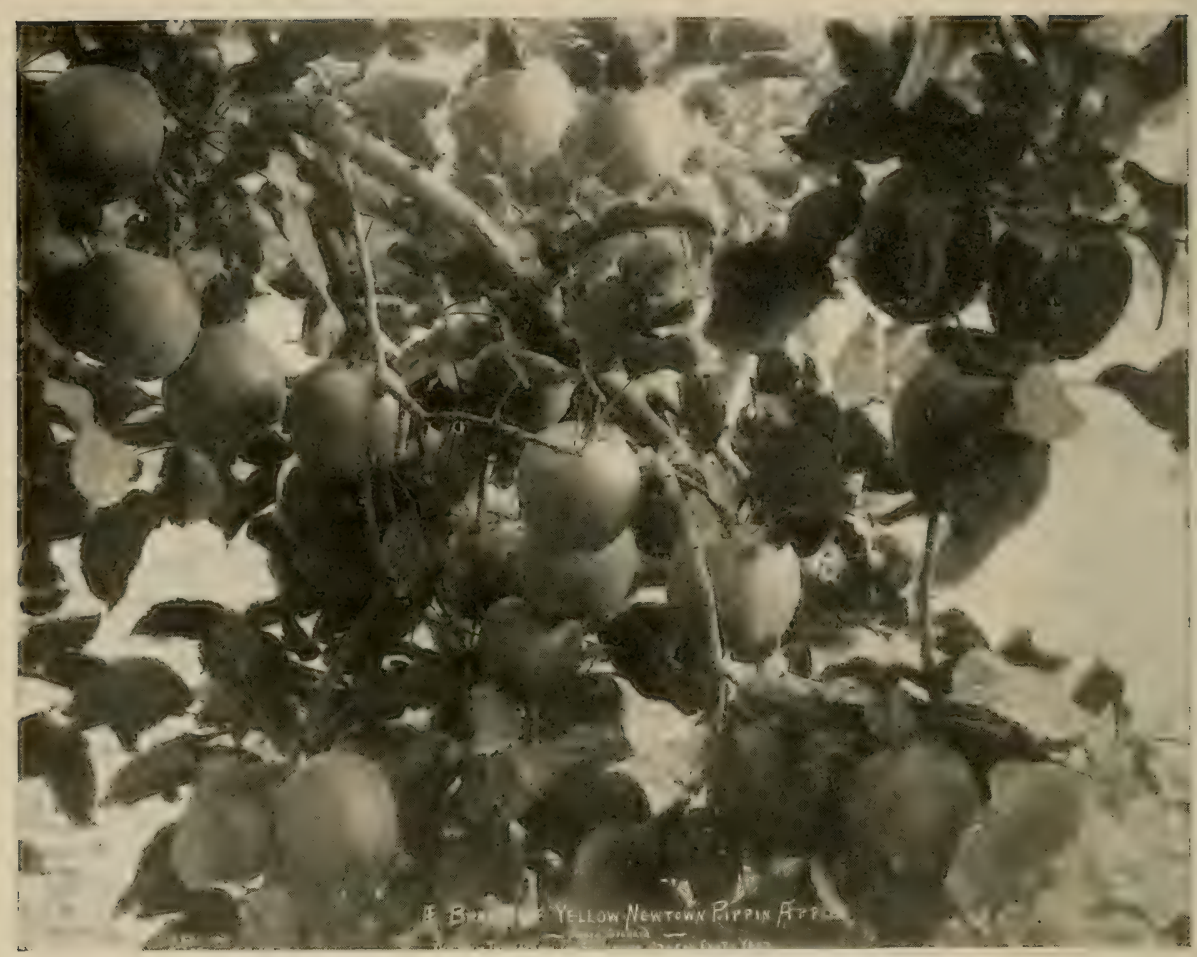

Yellow Newtown Apples grown in the Rogue River Valley, Oregon.

years may be. As a rule, one should have a shipping point sufficiently close to deliver two loads at least in a day.

The next great question to decide is what varieties to plant. One can be governed by what has proven suceessful in a district, what is bringing the highest price, what is in best demand. I will not undertake to name any of the varieties because of the varying conditions found in apples doing well in one place and not in another.

\section{Best Kinds to Plant.}

In Western Washington and Oregon we should not undertake to compete with those places east of the Cascarde Mountains in highly colored fruits. There are many fruits that do not require color to sell. I well mention a few. I would put at the head of the list the Gravenstein. Of course this is not a winter apple. It is standard in quality and has many desirable features, which make it the best of all apples. It is not only an eating apple, but is the best of cooking apples, and is better for canning than any other. Next to the Graven- 
stein in Western Washington and Oregon comes the King. This has good quality in many respects and sells well. Next to the King is the Northern Spy, which I think is the most valuable apple there is for west-side conditions generally. When I speak of the west-side conditions, I mean in comparison with the Hood River country east of the Cascade Mountains. There is one objection to the Northern Spy. It is a tardy bearer. I believe this fact can be overcome by the right kind of pruning. I have brought it into bearing in five years, and am satisfied that by right methods it ean be hrought into bearing early enough. Coming next in order is the Olympia Red, which is an apple of good color and quality. There is one fact about the Northern Spy which seems to be true of the Olympia Red. It seems to stand the blackspot canker better than any other variety. Black-spot canker is one of the pests we have to combat with on the west side. The Bellflower is also a good apple, but is not so marketable. It is desirable for home use. The Ortley is also good. There is another apple that should be planted more than it is. That is the Grimes Golden. This is one of the standard varieties that does not require color to sell.

\section{Get the Right Tree.}

The next thing is to select the trees to be planted. This matter is so important that I would rather pay a dollar, if necessary, for the right tree, than to get a poor one for nothing. If we make mistakes in the variety of fruit or kind of trees we plant, it may take five, six or seven years before this mistake can be overcome. It is not like dairying or poultry raising, where we can correct a mistake in a year or two. A tree that is well grown, and has matured naturally in the ground and not been forced in any way, has stronger vitality, starts out quicker, and makes a better tree than a weak one. I am going to explain just how you can tell a tree that has strong vitality. I prefer a three or four-foot yearling tree. I would rather pay an extra dollar, or five dollars, for a tree of that kind. The three or fourfoot yearling tree that is well grown will be quite strong at the bottom. and all the way from the bottom to the very end terminal bud the bua's are well developed. If the tree has matured naturally and has plenty of vitality, lying around each of the buds will be a little swelling.

The digested sap is started in the formation of stareh right around the bud in the spring. As soon as the climatic conditions are right, and a few of the sun's rays strike this bark, the activity begins in the starch and that causes the leaf to grow out. As the leaf grows it makes demand for sap which comes up through the sap wood.

The first start of a tree depends upon the starch stored around the 
bud. Be sure and get a tree that has this indication. Sometimes nurserymen in order to fill early fall order's, strip all the leaves off the tree to make it mature early. In such eases there would not be the storage of starch around the base of each bud. This storage of starch begins when the climatic conditions are right, when there have been a few frosts, and the indications of coming winter appear. The tree by nature has had warning of this end of the season, and the starch is stored there for the next spring's start. If the foliage has been stripped off early, or has been irrigated and foreed along, the starch will not be there. I sometimes advise people to grow their own trees, or have them grown for you by a nurseryman. That is the best method to get right trees. I would suggest that you commence in time to select your seions growing in the district where you intend to plant. Select them from the very best bearing trees you can find. Graft these scions on to the roots yourself, or have your nurseryman do so, then you will be sure not only to have a good tree, but to have the tree you want. Sometimes nurserymmen are careless and send out trees that one does not order, and sometimes this is done purposely, so if you grow trees you can be sure to have the trees you want. It may take several years.

\section{Preparing the Ground.}

Have your ground plowed and well harrowed. Give the ground as good preparation as possible. I have heard a great many say they would not plant an orchard until the land was thoroughly prepared. I have cleared the ground and planted trees the same year with success. I would rather plant as soon as the land is cleared rather than wait two or three years to prepare the soil.

The next thing is to stake out the field. If the land is rough it is quite difficult to get it exact without surveyor's instruments, but one can get very good results in rough ground. First run a line at some point where you can get as near a level as possible, and then line right through. I have found it convenient to have all stakes prepared. I first split up some stove wood 18 inches long. The stakes need not be larger than half an inch square. After they have been pointed a little, mix some lime in water, making a thin white wash, then dip the top end into the whiteriash. This makes them easy to see.

As a general thing trees are planted too elose together. If I were planting an orchard today I would not plant trees nearer than 30 feet apart. Take a soft piece of wire and make it just 60 feet long. Put a mark at the center of the wire. The man at the rear stake. looking at the stake across the field sets this 30 -foot stake at the mark 


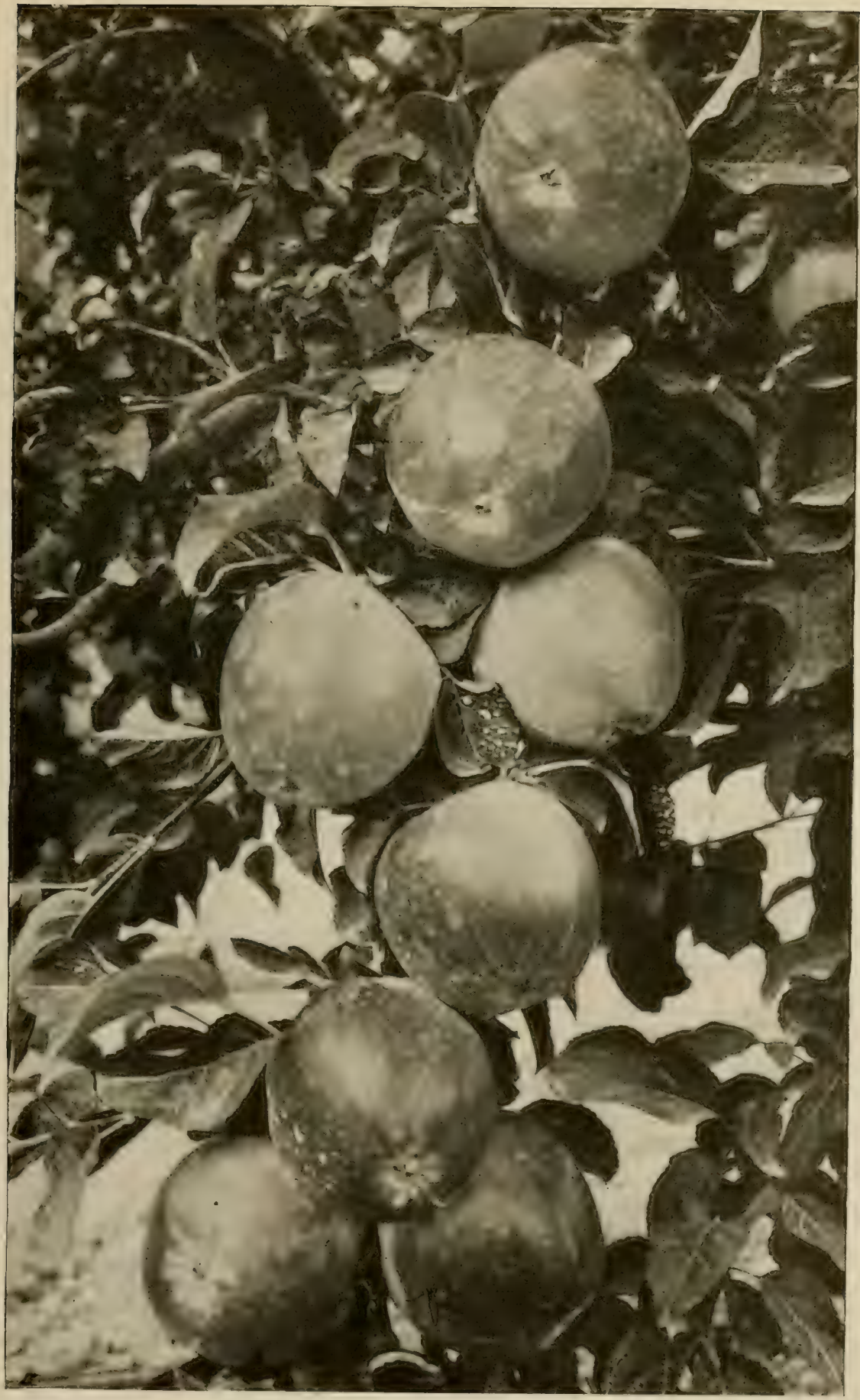

Branch of the Winter Banana Apple grown in the Hood River Valley, Oregon. This apple is at present the most expensive grown, commanding in the East as high as 25 cents apiece. 
on the wire, and at 60 feet as he advances. He always has two stakes to look across, and the third stake at the end of the row. The reason for two stakes is that on uneven ground the end stake can he seen. Then two stakes are used one can go considerable distance and not be much ont of line. Sighting across the field, next establish a line at right angles with the first. For the benefit of those who do not linow exactly how to do that, I will state a very simple method. Go out six feet on one of these lines and right feet the other way and it will he exactly 10 feet across that angle. Then you can be sure you have an exact right angle every time.

\section{Setting the Trees.}

After the land is staked make a planting board about four feet long with a notch in each end, and one in the center. When ready to plant put this center notch over one of the stakes, and then put a stake in each one of the end notches and take up the stake where the tree is to go, and dig a hole. Sit the two stakes back and put the tree in the notch in the center. The tree will then be where the stake was. One does not have to look in either direction. This is the most simple method that I have used. I have planted large tracts by this method. It works so perfectly that one conld not notice hut what it was exact.

When digging a hole for planting be governed ahout the depth of the hole by the nature of the soil. I would not dig as deep a hole in heary soil as in light soil. Set the tree, when it is planted, ahout an inch or two deeper than it was when in the nursery. Before setting out a tree, I would prune each root. I would not want to plant any tree that did not have from three to five strong roots, lateral roots, rumning out each way from the main stem. I would not plant a tree that had roots on one side. That tree would not be feeding evenly from the ground. Prume off each root that will not grow, if not more than two inches is left. I would not care to have more than 4,5 , or 6 inches of the root left. Prume them off on the lower side with a good sharp knife, making a long eut. When the tree has been placed in the hole and some soil put around on top of the roots, get into the hole and tramp the soil down hard with both feet. Just as soon as the leaves have started and the demand for sap begins there is a flow of sap.

If you have any reason to believe that the soil is not rich enough, use a little nitrate of soda right around the roots of the tree. A half a pound or less will make a wonderful difference. It is as essential that one has a good start in a tree as it is for him to have a good start with a pig or calf. 
At this point I might tell you of my own experience in planting fruit trees. I had several varieties, and had prepared the land in such a way that I had not cleared off the full extent that I wanted to plant on. I ordered a certain number of each variety. I had a little pride in the matter, and wanted my orchard to appear the best it could. I selected the trees, taking the best variety, and setting the best trees next to the road where they would show the most. In after years, I do not think one of those trees at the end of the row survived. They were weak, attacked by insect pests and climatic conditions, but every one of the first choice trees produced a good tree, and I believe that the first third of each one of those rows produced more fruit than the remaining two-thirds. My wife had considerable poultry and we saved the droppings all through the winter, keeping them in barrels so that nothing was lost. We also saved wood ashes gathered from the burning log heaps and mixed them together and used them around the trees, and we got just as good results as with nitrate of soda. Then put on your surface soil. Do much packing, so that it will not bake or dry out.

The next thing to determine after the trees are planted is what top to start the tree with. There are many places where a head reasonably high is much better than a low head. The trea needs plenty of sunshine. Damp weather and misty conditions are conducive to fungus and black spot canker. These pests seem to thrive minter these conditions. The sunshine will dry them up and kill them. Where there is not enough sunshine the trees should be headed up high enough so the air will circulate freely around under the tree and the sun get down there once in a while. This makes it much easier to cultivate. IIaving decided the heads of the trees after they are plinted, cut them all off uniformly to that height. If there is a strong prevailing wind, set the trees on the slant a few degrees torard the wind.

I do not know that there is any other method that will do as much as eultivating the land. I believe it is just as well to put in some kind of a crop, but never a grain crop. I have seen a mumber of fairly good orchards and as soon as they get a little too much seeded down to clover, they never did as well. Be careful to take care of an orchard from the start.

\section{Questions and Answers.}

Q. Is the present time a good time to set trees (February)?

A. If the ground is in good condition and can be worked. I would suggest that you book your order for trees early. Get your trees home 


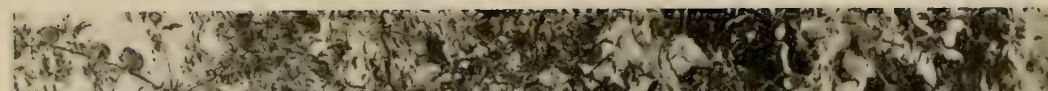
(11)

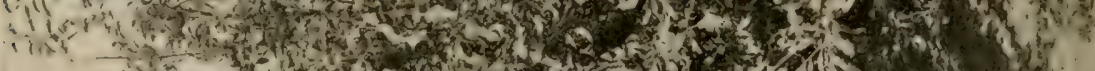



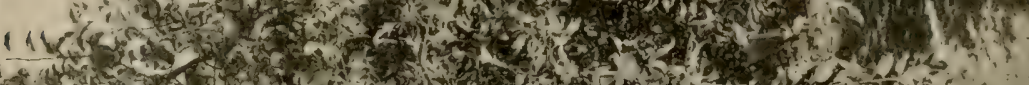

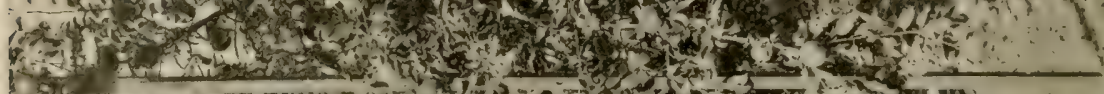

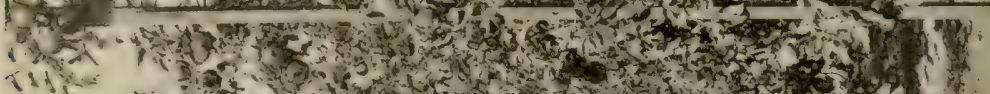
राth

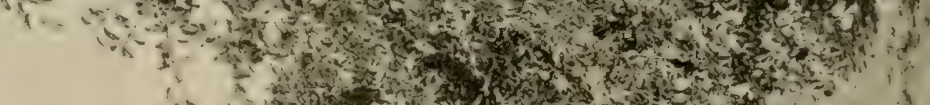

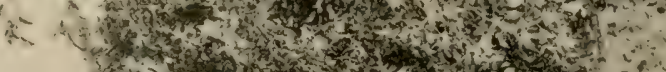



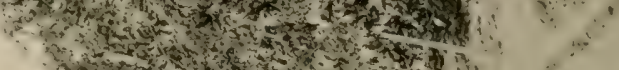

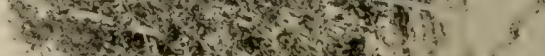

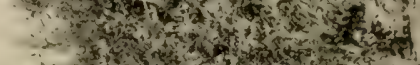

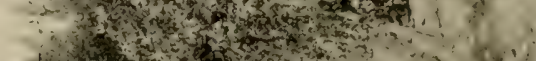

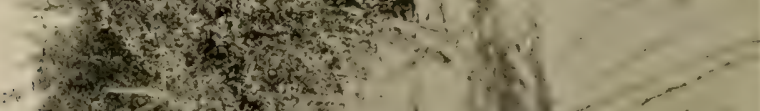

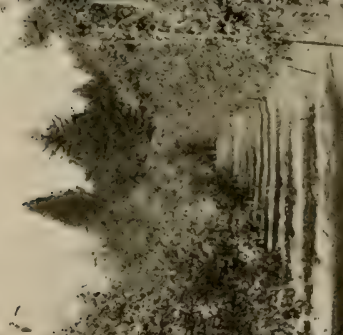



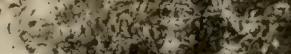

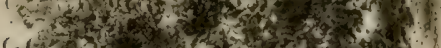

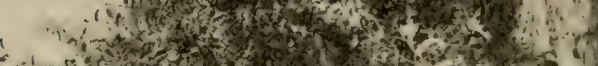

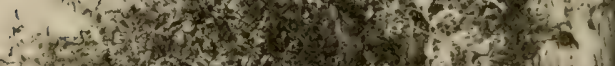

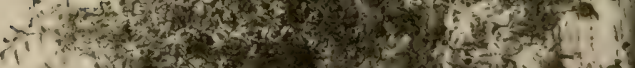

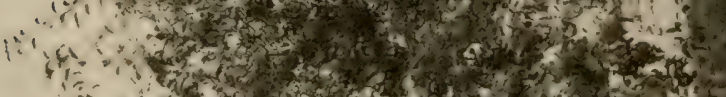

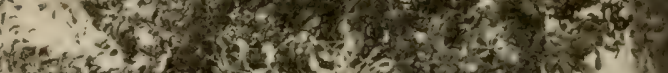

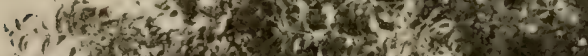

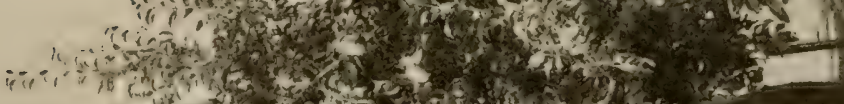
4 है।

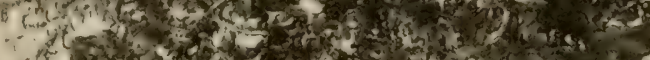

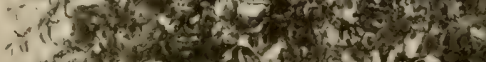

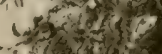

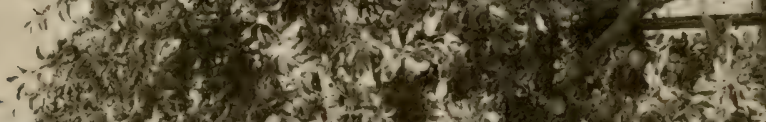

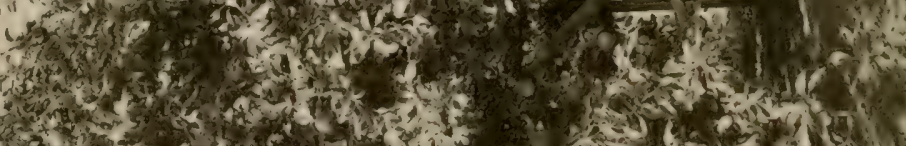

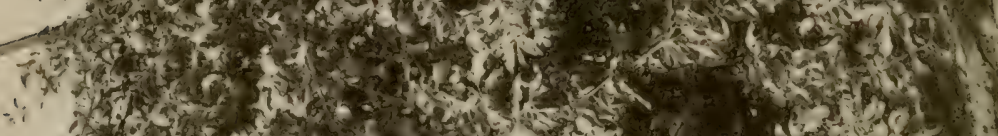

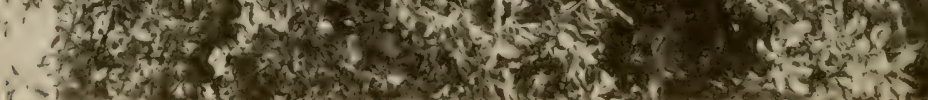


as early as you can. I would stipulate not to have the trees forced in the growth. Bury them, heel them in.

Q. If you planted trees this time of year, would you cut the tops off: Are you not liable to trouble from insect pests?

A. To your last questicn, yes. I never at least experienced any with healthy trees. There is sometimes difficulty with the skip jack beetle, which climbs up the tree and eats the buds. They are not particular what bud they find, so one cannot guard against them very well without dipping in arsenic.

Q. What is your observation about dwarf apples and pears?

A. For fillers? I think they are all right. Plant as fillers those varieties of apples or pears that come into bearing early. We have some varieties that are noted for their early bearing qualities, and I think it a good plan in planting trees to plant in a few here and there, one in ten is a good rule to follow.

Q. Have you tried burning cedar stumps out by char-pitting?

A. I have only had a limited experience in that. I tried one cedar stump in the winter time when it was very wet, and $I$ failed.

Q. Does your bulletin give full information about char-pitting?

A. Yes, the bulletin is written and has been published in the State of Washington and by the United States Department of Agriculture.

Q. How does char-pitting work upon green stumps?

A. My experience has been limited; I have to rely upon what others tell me. I have met several who have had success. They say that after a green stump is fired once it burns better than old stmups. In burning green stumps chop through the sap wood to get the fire into the interior.

Q. How will it work on extra heavy, wet ground?

A. All this winter I have not stopped for wet ground. Of course if you were burning in soil that would soon become saturated to the extent that water would stand in holes, it would not be likely to work, but with a soil that will drain reasonably well it will not make any difference how wet it is.

Q. What varieties would you use for fillers?

A. The Jonathan is good. The Wagener and Pearmain are good fillers.

Q. What do you mean by a filler?

A. A filler is a tree between the other trees. Sometimes they are put between the other trees as a temporary tree to occupy the ground until they are too large, then that filler is supposed to be removed. They are just temporary until the space is needed by the permanent tree. 
Q. What system for shading the tree would you suggest? Whick is the most desirable, a shingle. white-washing, or the Yucca palm?

A. Whitewash is all right in some places where the heat is not too intense. The simplest method is the shingle. Sometimes a piece of paper is wrapped around the tree and brought down to the ground a little below the surface, and is then kept in place bs a clod of dirt. That is a very good protection against borers, which sometimes are very bad. Whitewash is also good for borers, but I would add a little carbolic acid.

Q. Have you planted trees among stumps?

A. I have, but I would not plant a tree too close to one that I wanted to burn. A stump can be burned by the char-pitting method, by taking good care, right up close to a building. but it gets pretty hot down there in the ground.

Q. How often do you spray your trees?

A. I spray the young trees only when it is needed. When a pest appears, spray it. There is one exception; the trees west of the mountains should be sprayed at least every fall about the time the leaves are dropping, to prevent the black scab canker. Spray every fall with lime-sulphux. That one spraring would be sufficient to check most of the sealy insects.

Q. Should nitrate of soda be used then?

A. No. There is danger of over-feeding young trees. There is not any danger of overfeeding young trees during the early part of the season, but there might be in the latter part of the year, and the wood would not mature early in the fall. Check that growth by throwing some grain around so as to take that food away from the trees.

Q. If the soil needed lime and phosphate, how should it be put in when one plants?

A. If it needs lime (acid soil) a general application of 500 pounds to two tons per acre is the way to apply the lime.

Q. Have you ever tried grafting one pear to a larger kind to increase the quality?

A. No.

Q. Would grafting one pear into the top of a Bartlett pear materially affect the size without affecting the quality?

A. The bulletin on cross-pollination will answer that question.

Q. What is the best method of improving the soil;

A. By turning under clover or vetch.

Q. Should this be done two or three years before planting an orchard?

A. Plant your orchard, and if there is plenty of rainfall in the fall of the year, sow vetch. Vetch grows late during the winter. Sow 
it in the fail between the trees, and as soon as there is a satisfactory growth in the spring and the weather gets warm, plow it under.

Q. How near would you sow the vetch to the trees?

A. Within two feet. Just as near as you can plow.

Q. What height do you recommend to head the tree?

A. About two feet. If I were planting further east, where there are high winds, I would probably head the tree 12 to 18 inches, but not less than two feet.

Q. In burning out a stump do you dig in under?

A. No. Do not do much digging where there is sandy soil. Just dig out a little around the base of the stump, just about enough to remove one shovelful.

Q. How can one tell when to irrigate an orchard?

A. Take up a handful of soil and if it falls apart that shows it has not moisture enough. A cultivated orchard should be dry for three inches. That is what we eall a dust mulch on top of the soil.

Q. Is there any objection to raising potatoes between the trees?

A. No. Of course potatoes take a little potash from the soil, but that ean be returned. trees?

Q. What effect has raising strawberries by irrigation between

A. Raising any crop, especially strawberries, takes away a little of the potash. Any cultivated erop is all right.

Q. What is the lowest elevation suitable for raising apples?

A. I do not know of any reason why they could not be grown practically at sea level provided the soil is not heavy, but the apples would not have as good keeping qualities as those raised at a higher elevation.

Q. What is a good method to keep squirrels away?

A. Shooting, trapping and poisoning. 


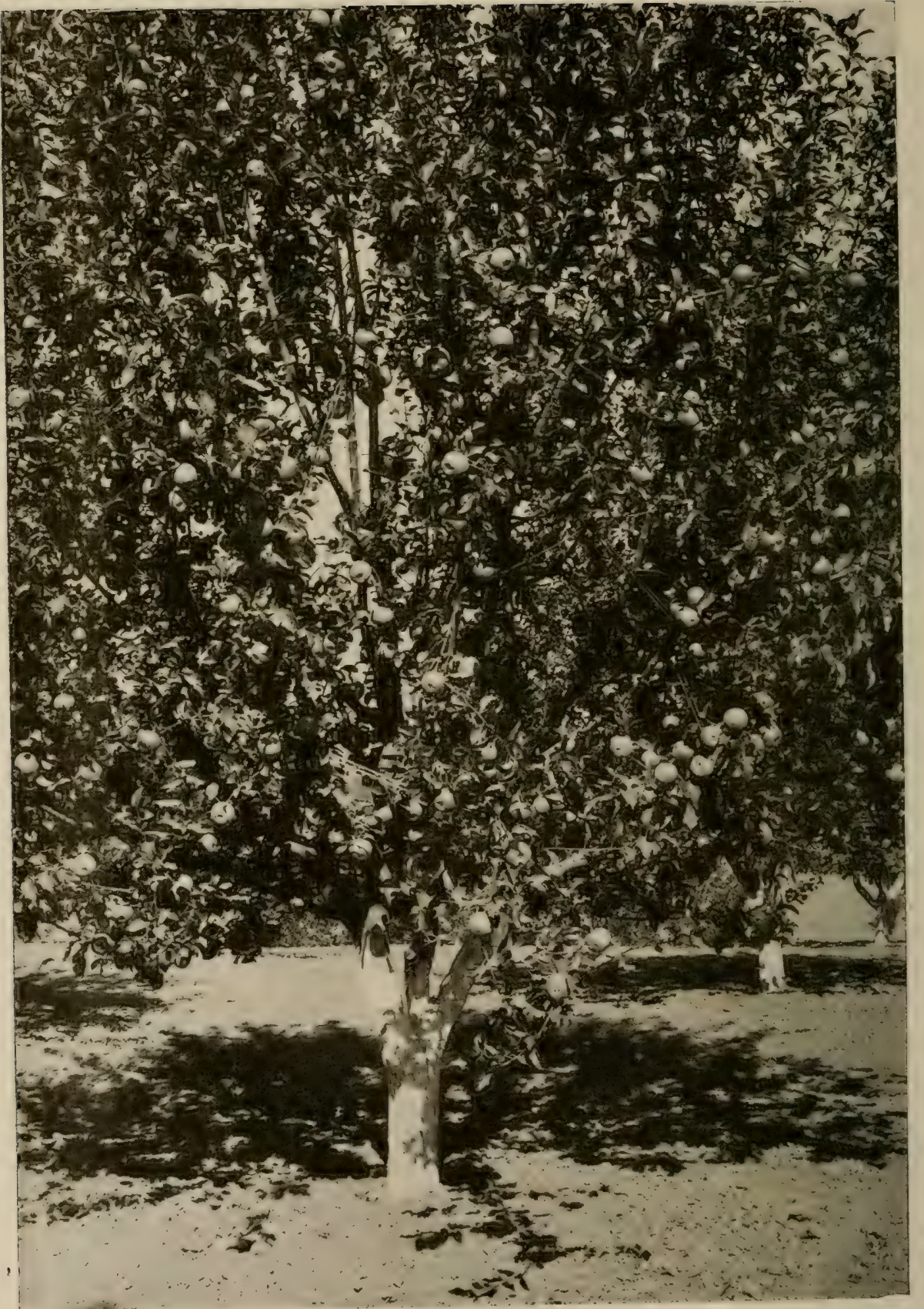

Fine specimen of a Spitzenberg Apple tree grown and developed by one of the lecturers in this course. 


\section{First Things in Apple Culture}

Charles A. Cole, of the Oregcn Agricultural College.

F A MAN were to come to me and ask what is the first thing to
do in beginning an apple orchard, I would not hesitate to tell

him to look into the proposition very carefully and see just what returns are being received by different growers and talk with the man who is getting the highest returns and find out all he can about it, and after he finds out just what he can expect from an occupation of this kind, then take a look at himself. One of the important rules of business is to find out just what you want to do and are able to do, and it is more so in apple culture than in anything else.

You want to find out whether you have patience or courage enough to wait several years for returns, or whether you have endurance to go out and live with your trees. If you find out that you can do so, it is a pretty good thing to go into apple growing. If you cannot, there is nothing in it.

Now if one finds that he wants to grow apples, the first thing is to look for a location. There are many mistakes made in this line of business, for in looking for a proper locality for apple growing there are many different points that have to be taken into consideration, and one of these is markets. You do not want to do as a man I heard of, who had been raised in an eastern state and lived in Chicago, or some eastern city all his life, and finally decided to come to Oregon. He did not know Oregon conditions, but was sure he would like them, so bought land in Eastern Oregon and was going to grow apples. When we looked him up he was 150 miles from a railroad. That is what I mean about good markets. Be sure and have good trausportation if you are going to make a success. Buy near a railroad, for country road transportation is very difficult. If you lay out an orchard a long way from a railroad, but are sure that there is going to be a railroad in five or six years, it is all right. It makes a great difference whether apples have to be hauled five or ten miles.

There are two or three different kinds of markets to be taken into consideration. Some people like special markets. They have so many customers, and those customers will pay them a good price, like some people have markets for chickens, eggs, butter, etc. If you want a market of that kind, you must go near a big city, and you want a lot 


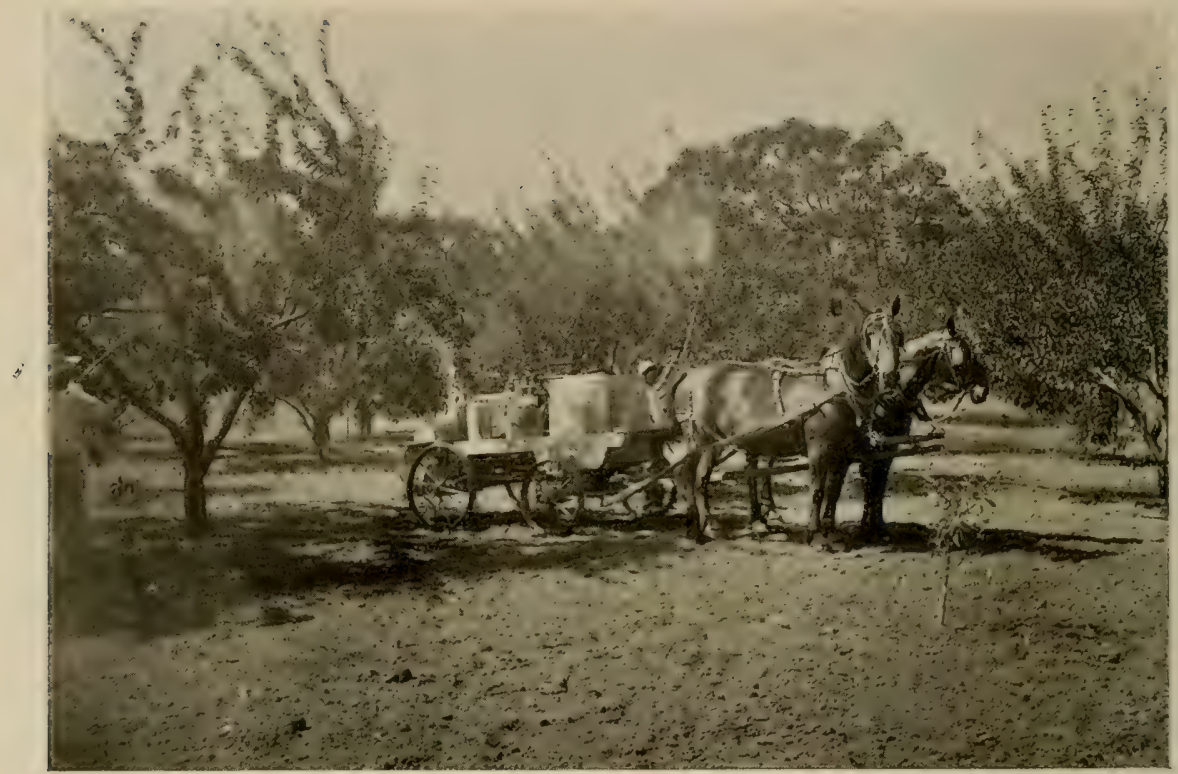

Spraying an apple orchard in the Yakima Valley, Washington.

of money to start with, because it is going to cost a large amount to put this market in shape in order to bring high prices.

The market almost all apple-growers want to go to is the wholesale market. It does not make much difference where you go, just so you go near a railroad. Some time ago people used to ship apples in sacks. They did not know the best way to get apples to market, nor understand packing as we do. With our up-to-date packing appliances and our much improved expressing, we can grow apples right here and put them on the market in Europe just as easily as a man can get apples in Ohio and send them to New York City, because we have the first-class means to get them there. After we have taken these things into consideration, we have decided to buy near a railroad, of course. Two railroads are better than one.

Then you want to take a look at the lay of the land in regard to drainage. which is one of the most important things to apple land. I mean both air and water. It is just as important to have air drainage as water drainage. Get land that is free from frosts, for by so doing you are likely to have land that has good water. If you select a piece of land that lies down in the bottom, that has no outlet to allow the air to pass in and out, you will be pretty sure to lose a number of crops by frost. If you choose a piece of land out in a large valley, you will be sure of the same trouble. I have seen land where they were 


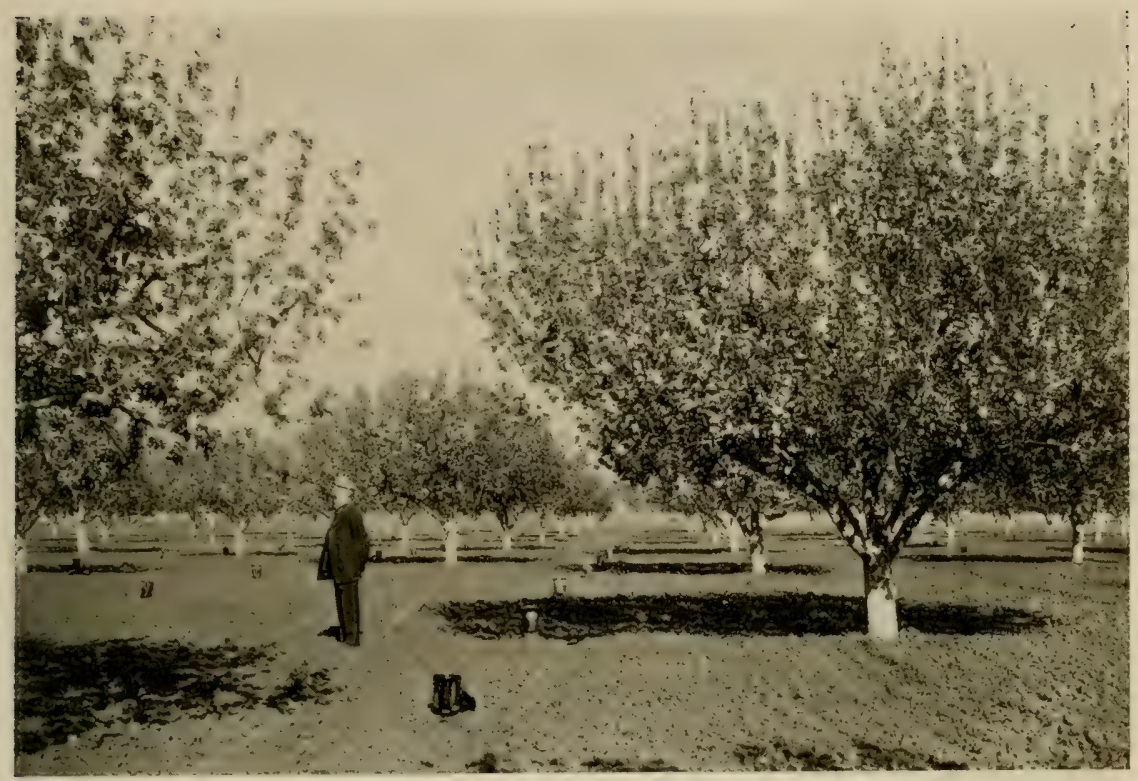

One of the famous apple orchards of the Rogue River Valley, Oregon, showing smudge pots.

troubled very much by frosts, and a man going 100 feet higher up never lost a crop, so be sure you get just the right height. See that the land is up high enough and that the valley is not blocked, for if it is the air will not pass in and out freely and you will be troubled with frosts. Sometimes a group of trees will do that. An orchard can be planted in the valley the same as on the hillside, if the valley is not too large and is not blocked in. You will find if you get near a river, that is, if there is a pretty good slope toward the river, or if there is a large body of water, you will not be troubled with frosts, because the rivers or body of water keeps off the spring and the fall frosts. It keeps the air from getting warm in the spring, and hence keeps the fruit from growing too soon and retains the warmth in the fall and prevents the air from cooling down to frost point. These are all things you want to take into consideration when you are looking for land.

Then also the soil must be considered. This is a matter of very great importance. You must see if it will produce a good crop of wheat or is good for vegetables. If it will grow these things it will grow apples, but you want to get down into the soil. Take a soil augur and get down into the earth four or five feet; bore holes all over the tract of land. Find out whether it is of good depth or not. If it is hard you cannot grow apple trees, because they will strike 




The results of careful apple culture in Oregon. 
that hard ground and that will keep them from growing deep and strong, and also there will not be enough moisture. In July and Angust, when you want a large amount of moisture, you will not have any, and your apples will not grow large enough to be marketable. You should have at least four or five feet of good soil, because, as I have said, if you have not, it will not retain moisture enough to grow apples, and just when you want to put the growth on the apples you will have nothing there to grow them, and the apples will be small. I have heard of a man who grew apples on 18 inches of soil, but he had to irrigate his orchard. A large per cent of our orchards are not near irrigation. These things should be taken into consideration, even where there is a good irrigation system, because one wants to be sure of his crop, as sometimes when water is needed there is none to be had, and another crop is lost, and then even if you do not irrigate just at the right time, your erop will be brought down in market value. If you buy land that has deep rich soil, you will be sure to have moisture just when you want it and a good marketable crop. There are certain ways of doing things and you want to find out the best and then do it that way. You either want to make good or make a failure, so you want to select land that has fertile soil.

Another important question is whether you want land that is already cleared and planted or not. If you have the money to put into a growing orchard in a highly eultivated section, all right, but many of us have not. You can get a good piece of land in an uncultivated district, but generally the difference in the price is not enough to warrant you to buy land with timber on it. It takes from $\$ 25$ to $\$ 250$ per acre to clear the land and get it ready for trees. You might be able to get it cleared and in cultivation, but you might pay out five times that much before you get it into cultivation, so you want to take this into consideration. Then it would be best to plant the land to something else for the first year or so, especially an oak grubbed land. Allow the roots to die out before planting apple trees. Tost people have not enough money and patience to wait any longere than they possibly have to for the orchard to bring them some kind of an income. In new soil you want to get all the roots and other matter out, and in old soil you want to plow very deep and harrow it down thoroughly.

After the soil is ready for planting the trees, select what varieties you are going to grow. That is a very important point. It mostly depends upon what market you are going to supply. If you are going to grow a home orchard of about 150 trees or so, get a number of different kinds, but not so with a commereial orchard. You must stick to your locality and the market there, and find out what kind of 
apples have the best market, that is, a commercial or wholesale market. In some localities you can grow Spitzenbergs, in others Jonathans. and still others Newtowns, while in others you may be able to grow and make a success of all three. Therefore, before selecting your variety, the best thing to do is to find out just what variety you can set out. You do not want to set out some kind with which no one has made a success.

A man in Texas wanted to find out how to grow Spitzenbergs there, hecanse they were growing them in Hood River and making a successs. and getting $\$ 3$ per box, and he wanted to get the same result. We wrote and told him that we knew nothing about growing Spitzenhergs in Texas. There are many varieties that bring high prices to some people. Some people grow Spitzenbergs in one place because of high prices, while in another place they grow some other kind because spitzenbergs do not pay. The Newtowns bring in more money than Spitzenbergs, because Spitzenbergs produce only about every other year. From Newtowns you can expect and have a good crop every year. Inquire of the apple-growers in the locality where you have the land and plant the lind that they have had the best success with.

Now about mixing varieties. You have undoubtedly heard a great deal about that. We usually plant about four or five rows of Newtowns aud one row of Spitzenbergs or Arkansas Blacks for pollenizing. The pollenizing question has not heen thoroughly threshed out ret, and many people make fun of it, but they are taking more notice of it now than years ago. There is something in mixing apples, that is by pollenizing one variety with another. You ean set one row to five and get good results; that is, four rows of Newtowns and one row of Red Fall Pippins. I would not advise putting them in closer than that. Some people put a branch in the top of a tree. They have a Newtown tree with an Arkansas Black branch in the top, but the trouble is when they pick them all together. The Newtowns are liable to get mixed with the Arkansas Blacks. Arkansas Blacks should be kept in one tree and Spitzenbergs or Newtowns in another, and you will have just as good results.

After you have decided what kind of variety you want, then find out what kind of trees to plant; which class, first or second. If I had my own orchard I would want to plant it in nothing larger than one-year-old trees. They grow hetter than two-year-old trees. Some prefer budded and some grafted trees. In setting out grafted trees, you have a two-year root system and a one-year top, so I think that would be the best tree to get. It does not pay to get a number of large trees. because the others make the best growth. I met a man the other day who had taken over several hundred trees from his neighbor 


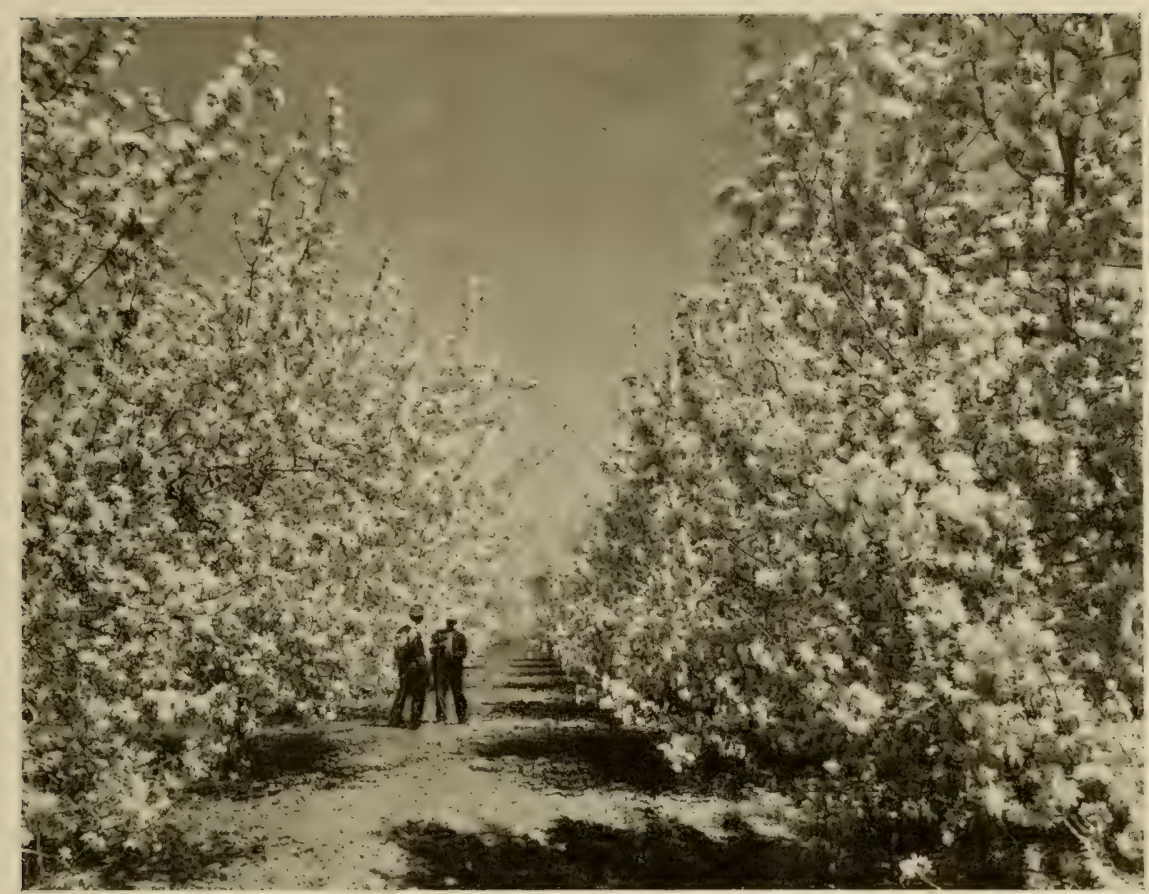

A Spitzenberg orchard, Hood River Valley, Oregon, in full bloom.

who had too many trees. They were all large trees and he lost about 12 per cent of them. Then he got several thousand small trees-not much larger than a lead pencil--about one-half inch in diameter, anci he got a good growth out of them. You want to get a tree with a lot of fiber shoots. If you have a big tree with a long, straight root, and 110 fiber shoots, you will not get a good growth, and it will not make any better tree than the small one. In the second year you will note the difference, so to get a good growth of trees be sure to get a small tree with a great bunch of fiber shoots. Do not try to get too much for your money. This is the main point to take into consideration. You want to pay as much attention to the roots, as you do to the top of the trees.

Now, in laying out orchards, what is the best time to plant trees -Fall, spring, or when? If you can get first-class trees, now is the time to set them out. There is no danger of their freezing to death be. fore spring, or, if you have to wait until spring, set them out early before the growth starts. Your trees will be 50 per cent better if set out at the right time. About February or the first of March wher we have some nice weather, would be a good time to set your trees. 
The one advantage of planting trees in the fall is that they can start to grow at onee in the spring. If they are kept over until spring you may not be able to get them until late, and they will be almost a year behind. If you cannot get your trees in the fall, take adantage of the first nice weather in the early spring, about February to set them out. I set out a thousand trees in Mareh and lost three out of that thousand. My neighbor lost about three to every hundred set out, sc it depends upon how you plant trees more than upon the time.

Another very important thing is how far apart trees should be set. In some localities of the state you can set them closer than in others. Consider the conditions of the section in which you buy roum land. The trees ought to be from 30 to 35 feet apart. About 50 trees to the acre. A great many are as close as 25 feet and many closer than that. You may set your trees close together, but they will bear so much and no more per acre. You save money by setting them far apart. They should be 30 or 35 feet apart to get a maximum crop.

In laying out an orehard what system should be used? I like the square system better than any other. Set out in squares about 33 feet apart. In this system you always have a roadway to haul your machinery through in fall and spring. Another system is what is called the quincumx. This is an arangement made lyy planting four trees and one in the midlle. All fire trees measure exactly :3:3 feet from each other. If you get 100 trees in a field by the square system, you will get about 175 by the quinemux system. Now, there is another system that is called the hexagon. There are seven trees in a group instead of five. Just place one in the middle and six around it; all exactly 33 feet from each other. By this system you can get in 15 per cent more trees than by the square system. It being used very successfully. The main advantage is that you can get more trees to an acre and still not crowd them, but you cannot have a road to drive through in that system as in the square system. If you want to grow something between the trees, the square system is very beneficial. The filler system is very sucessful and especially so, if you want peach trees hecause they grow about three or four times as fast as apple trees and can therefore be used very successfully for fillers. The trouble with the filler system is that most people will not grub them out when they ought to, even when they know that it is detrimental to their trees not to. Apple trees are also a crood filler. if taken out in time, but most people neglect to do so and the first thing they know they have pruned their orchard to death. Everything that is done in an orchard should be done to better the tree. Keep this in mind when you go into the filler business.

Now, another thing you want to be careful about, is to get your 


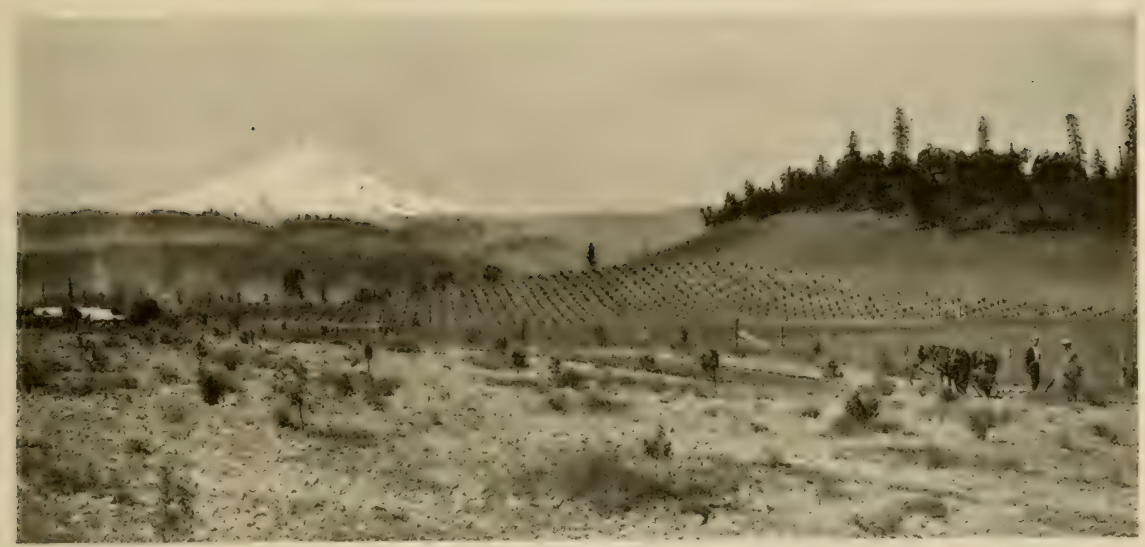

Vista of the Hood River Valley. Oregon, showing Mt. Hood in the distance.

trees in perfect rows. They always look better and are easier worked. One way to accomplish that is to take a wire long enough to reach clear across your orchard and get a stick as long as the distance you want your trees apart, say 30 feet, measure the wire and solder a little piece of wire on it every 30 feet. Wire is better than bicycle tape or rope, as it will always be uniform. After you have soldered the wire, you fasten it at one end and use a little pulley at the other to pull it perfectly straight, and in that way your trees will all be exactly even, then move it along as you go. You may use a rope and pegs, if you are not planting too large a piece of ground, and you will have to do more measuring than with a soldered wire. You can make the pegs as you go along, or either pull them out after you have planted the trees. One man told me that he always split pegs because it was easier than pulling them out. One test whether your rows are straight or not is to look across diagonally. If you look across the field that way, you will have an idea of just how much out of line you have the trees. An inch or two out shows very plainly that way. Of course, several different methods are used in getting them in line and their rows straight, but I think the wire method is the most satisfactory. The main point is to get your rows perfectly straight from all sides, or from any direction you may look at them.

\section{Questions and Answers.}

Q. Is there a difference in the taste of apples grown in irrigated or unirrigated land?

A. I have seen a difference in the taste of peaches grown on irrigated and unirrigated land. The difference was for the reason 
that the land was flooded just at the time when the peaches were ripening, and the result was a very watery taste. Hence you may do the same thing with apples. Otherwise I think there is no differenr.

Q. What is the main advantage for preferring the square system?

A. The main advantage is that you can work it easier, and can drive through between the rows without any trouble.

Q. What is the use of pollenizing, does it make the apples any better, and what kind of apples would you use?

A. The main purpose of pollenizing is to get a better color. You want to plant five rows of Newtowns and one row of Spitzenbergs, or five rows of Spitzenbergs and one row of Arkansas Blacks. Use the Spitzenbergs for the Newtowns and the Arkansas Blacks for the Spitzenbergs.

Q. How about burning smudge pots?

A. I do not know much about smudge pots, but they claim that it is a success in some places, while in others it is not. It depends upon what locality they are used, and also upon the size of the valley. They will do more good in a small valley than in a large one.

Q. Is fern a good fertilizer?

A. Fern is almost too much of a fertilizer for me. It grows too fast. The best thing to do with fern is to pull it out with all the roots you can and burn them, and keep the small ones down as they come up. The fern land is usually good for apples, if you can keep the fern down.

Q. How about growing potatoes between the fruit trees?

A. Well, that might do, if you keep them far enough from the tree. You do not want to do like a man I once talked to. He had strawberries among his apple trees. and one-half of them were about five feet from the trees and the other half he had the trees setting in the strawberry hills, and then he wondered why his trees there did not do so well as the ones where the strawberries were five feet from the tree.

Q. Does it make any difference whether you set trees on the north or south slope?

A. No, I think not. Of course, it depends upon the climate and on how much sun you have in the summer. If the sun is very hot, I would prefer the north slope, otherwise it makes little difference. Grapes must be planted on the east and south slope.

Q. What is a good fertilizer for new land before planting trees?

A. I would not use any fertilizer for new land, but I would allow the land to lie idle for a year or so in order to rot ont all the roots and also kill some of the insects. 
Q. Is it a good plan to raise hay in an orchard;

A. No, because the hay takes out all the moisture in May and June and in July and August, when you need it to make your apples big and marketable, you have none.

Q. How about clover?

A. That is worse yet, because you do not sow that every year and it draws moisture all around.

Q. How about planting berries?

A. That may be all right, provided you do not come too near the trees, and I would grow nothing among my trees after they are four or five years old. If you plant berries, plant them about five feet from the trees and each year plow out a few more, so by the time your trees are about four or five years old you have plowed out all the berries.

Q. How is vetch for a fertilizer if sowed early in the fall and plowed under in the spring?

A. That is very good, provided you sow it early enough. It ought to be about three inches high by that time, so it is about eight inches high when you plow it under.

Q. How about growing apples on land where nothing else will grow?

A. Apples are not likely to grow there either. Grow apples on land where vegetables and wheat grow good.

Q.. What is the best way to keep trees over winter, put them in a cold storage cellar or not?

A. A cold storage cellar may be all right, but I prefer laying them out on the ground and covering their roots with dirt.

Q. In setting out a home orchard would you get a tree of each kind or several trees, say about 50 trees?

A. I should get a tree of Astricans and one or two of Gravensteins and several trees each of the winter apples, such as Jonathans, Newtowns, Spitzenbergs, Arlkansas Blacks, Winesaps, etc.

Q. How about Baldwin apples?

A. They are all right as long as they do not get the Baldwin spots. We do not know what causes them. but they start in the middle of the apple and come out.

Q. How about elevation? Would 2,200 feet be too high.

A. I would not go over 2,000 feet, but it might be all right up that high, provided it is not near a mountain. 


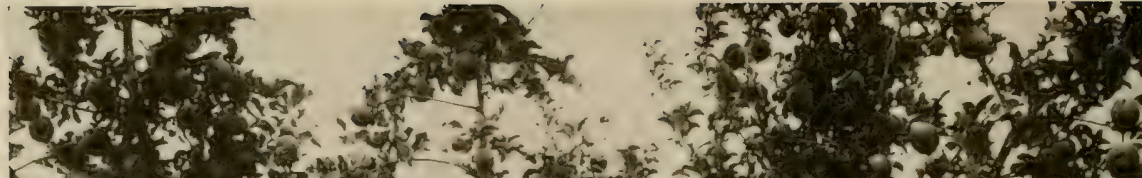

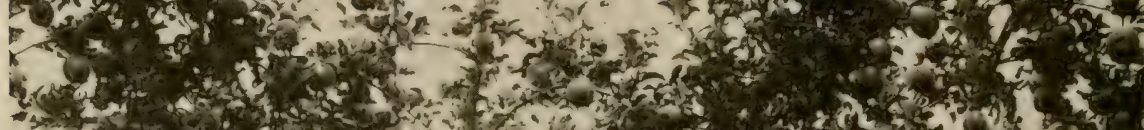

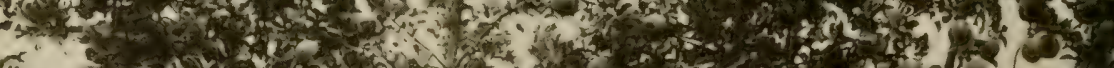

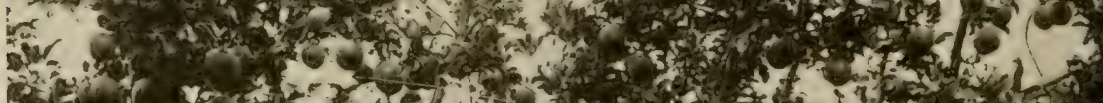

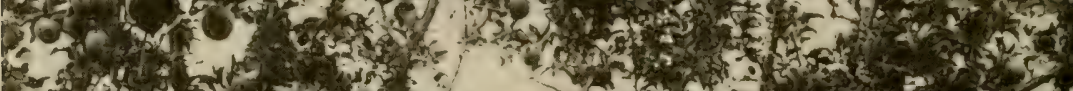

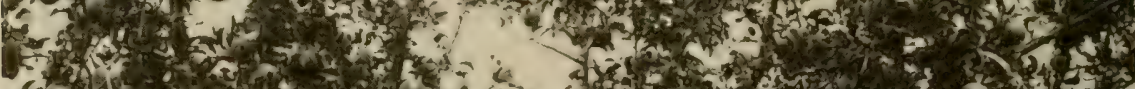

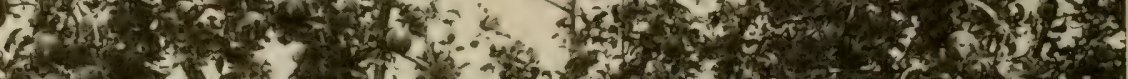

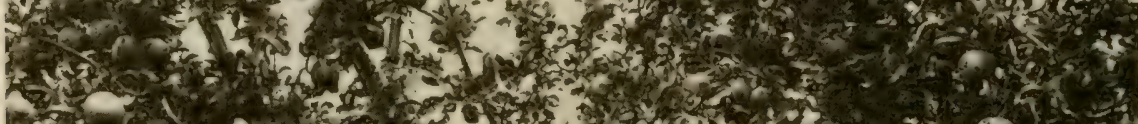

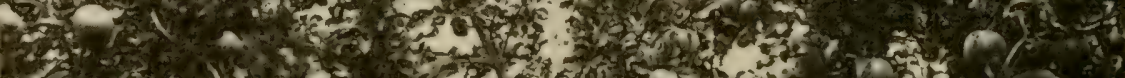

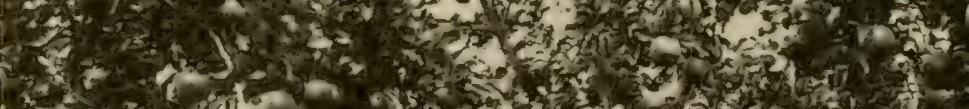



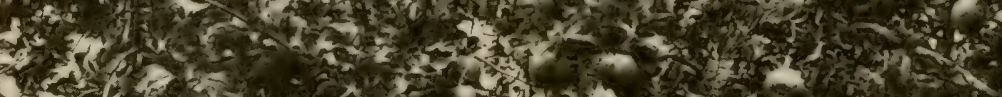

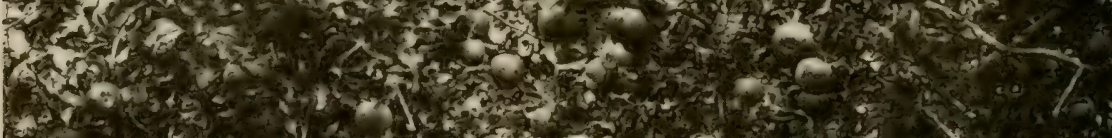

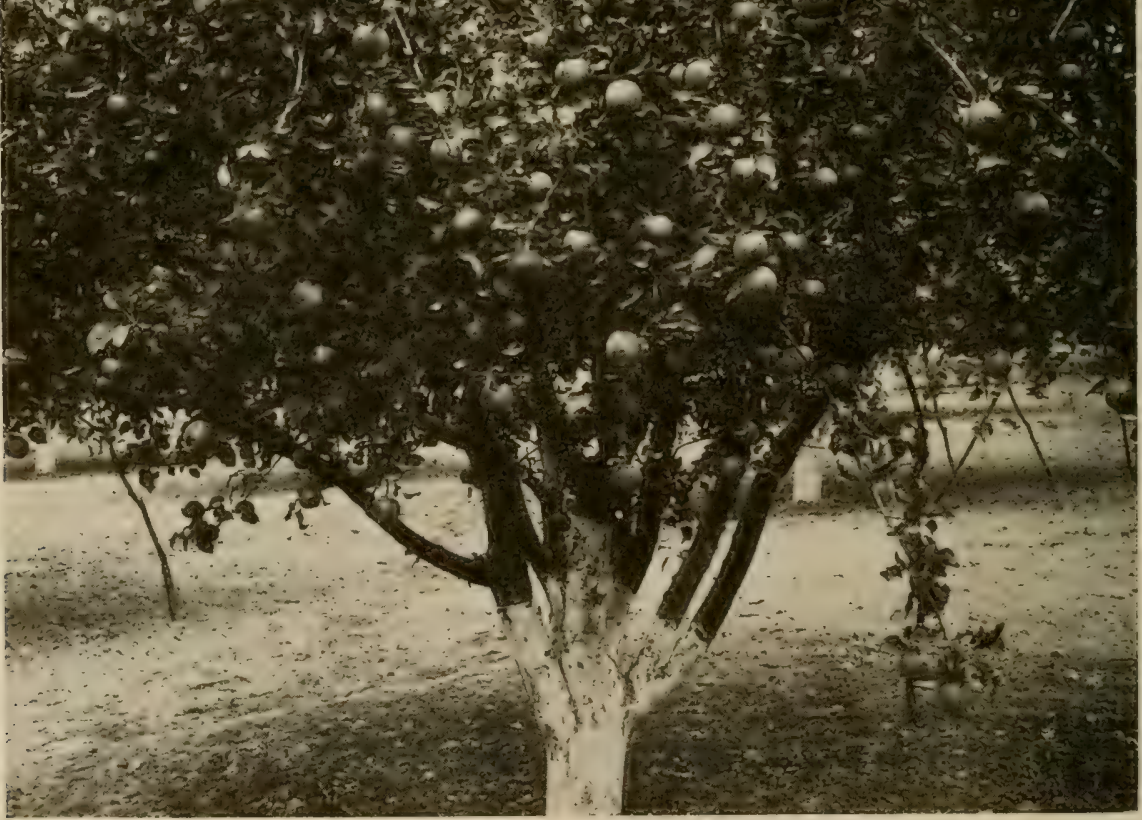

Practically a perfect specimen of : Fellow Newtown Aple tree growing in one of the famous apple districts of oregon. 


\section{Management of Orchard Soils}

By Prof. C. C. Thom, of the Washington State Collage.

I

T HAS been said that agriculture and horticulture might be likened to a man. The growing of crops, fruit and trees might represent one hand of a man; the raising of live stock and the marketing of stuff, the other hand; but attached to and supporting all that, is a man's body or trunk, which we will liken to the soil. Above all is a man's head, which we will liken to the man himself.

I will leave it to you to decide which is the most important, but it seems to me that aside from all things, one must have the trunk for a support before he has the right or left hand; this brings one back to the soil. I believe I am right when I say that the soil is the most important part of agriculture. On it depends every other phase of that art. I venture to say that because the soil is so common ana we tread it every day, we know so little about it. One will hesitate to say why. We till the soil because it is a most common practice.

It is my purpose tonight to explain why it is necessary to till the soil and keep up its fertility. I will liken the soil to a manufacturing ylant. A large manufacturing establishment must first have a building, also raw material and workmen. These three essentials will turn ont a finished product. Consider the soil as an establishment for manufacturing purposes. First consider the plant itself, which we will liken to the soil; next consider the raw material, or the chemicals in the soil on which the plant feeds. As you all know, these chemicals and materials have to be bred before the plant can feed upon them. Next comes the workmen. Possibly this subject has not been mentinned before, as we profess to know little about it, but I am going to tell you that the workmen in that large establishment are bacteria.

We will begin with the plant itself and analyze it. An ordinary soil is composed of two great bodies or parts; the mineral part, or inorganic matter which has come from broken down rocks, and the organic matter. These constitute the raw material with which these workmen have to work. The inorganic matter comprises sand, silt and clay. Organic matter is the decayed remains of plants and animals. Sand and clay may vary in color. Sometimes they are almost pure white, and at other times they are very dark. There are all types of clay, but sand is nearly always gray or whitish in color. 
It is composed of inorganic substances and hard particles. Sand is the coarser particles of the soil ; clay is the same material only it is broken into finer particles. One can grind sand like coffee or pepper and make pure clay out of it.

We will now consider the organic matter. Humus is always black in color, therefore black soils are rich in humus. From organic matter we get part of the plant food; from inorganic matter we get part of the soil solution that goes to make up the plant; from sand and clay we get, first of all, lime. Lime is essential to the life of a plant. Next comes potash, phosphate and nitrogen. These four essentials, with the addition of a little iron and a few other substances, which are never lacking, build up a plant. With these alone plant growth is impossible. A plant must have water. We likened the soil to a manufacturing establishment and the soil itself to a building; these are the raw materials; we will liken water to the transportation facilities that hring these finished products to their place of constmmption. For instance, there might be plenty of bread in Boston, but if there were no wheat, no flour, and no railroads, it would not do us any good, so if there were no means of bringing these substances through the medium of water to the plant, it could not grow. These essentials in available form constitute fertility. If any one is in an unavailable form, that constitutes unfertility.

Possibly some of you have read bulletins from our Agricultural College setting forth the fact that the soil contains water, phosphates, lime and nitrogen, and drawing the inference that the soil will grow so many tons to the acre for a certain number of years. The author of these bulletins assumes that these are not in a raw state, but a finished product and they are manufacturing elements for the plant to use. It is a mistaken idea that one can analyze the soil, add a chemical, and determine how many crops can be grown in a certain number of years. I am fully convinced that this is an erroneous statement. I read a statement in a bulletin not long ago about a certain valley not far from here in which there are orchards bearing 600 boxes of apples, but that in twelve years they cannot produce anything, and I said most emphatically I did not believe it. One would think from such statements that if a plant contained an element of plant food the plant would grow. Those elements are present, and yet the soil may not be fertile. We must have workmen to produce the finished product, and they are bacteria. In every manufacturing establishment there are some men that pay their employer a good profit on all they do, and other's who are barely earning their wages. There are some bacteria in the soil which, under all conditions are working, but under some conditions barely earn their wages. In other conditions they 


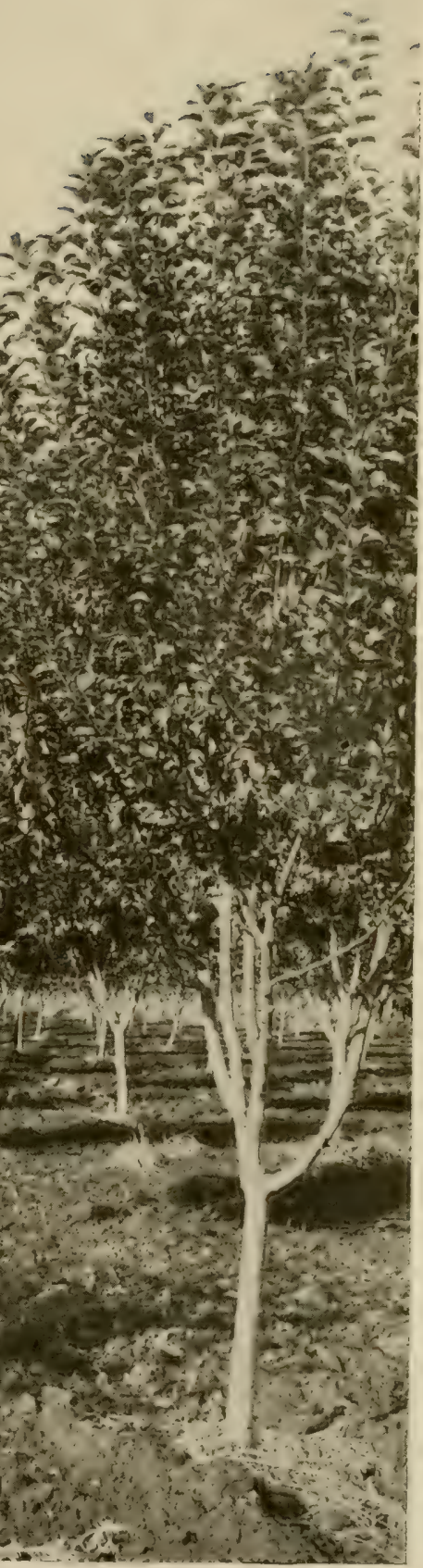

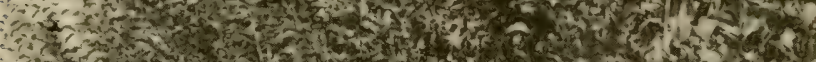
37 th $x_{i=3}$

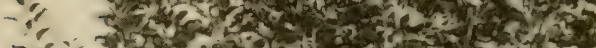

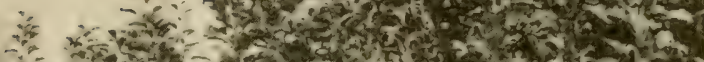

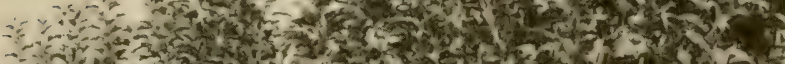

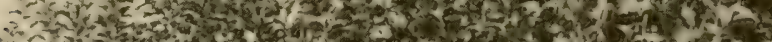
W.

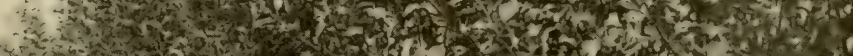

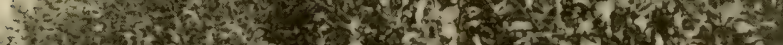

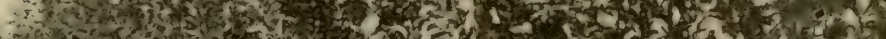

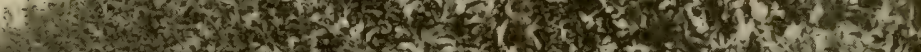

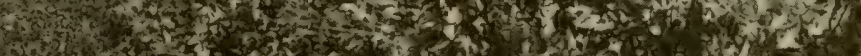

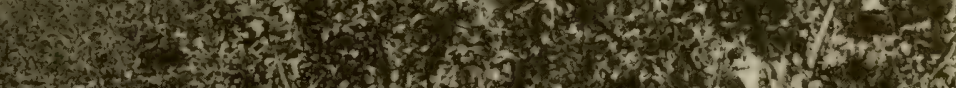

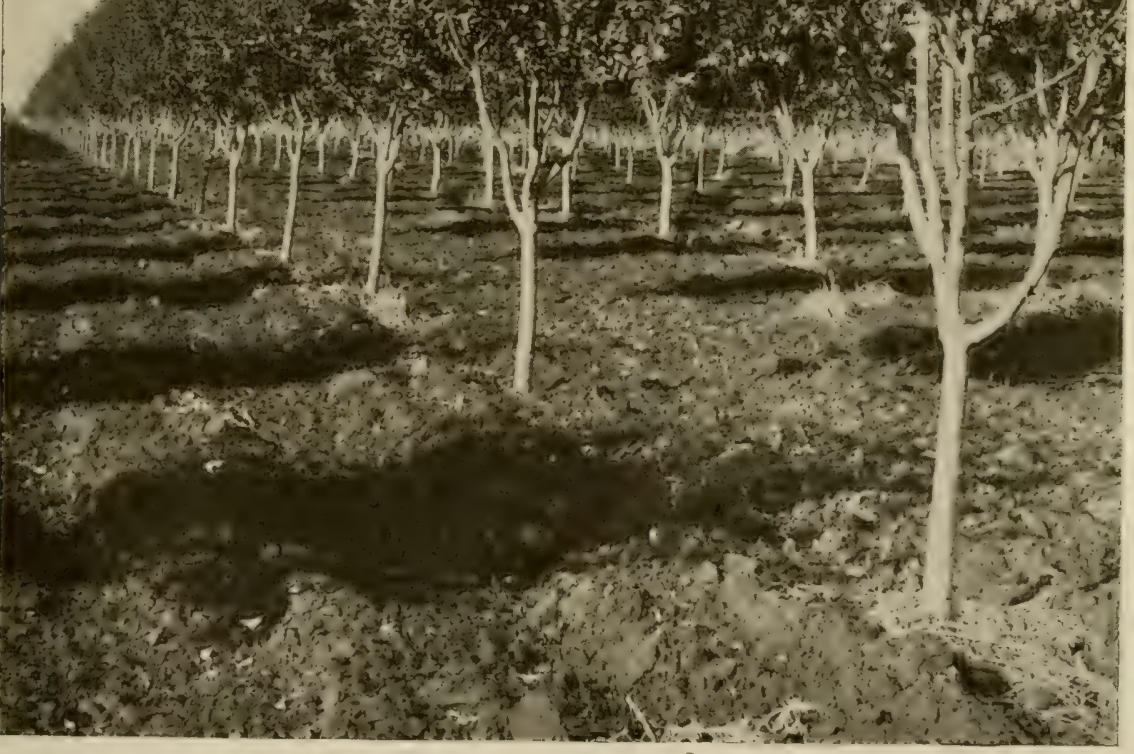

A famous apple orchard in the Walla Walla Valley, Washington. 
give you a grood dividend. This brings us back to the point that the condition of the soil makes the difference between a good and a poor crop, and that the condition of the soil makes either a good or a poor environment in which bacteria may do their work. It is not lime that liberates the potash; it is bacterial action that does it. I have a piece of chalk about a third of an inch square every way. If it were composed of ordinary soil there would be over eleven million bacteria in it. In my private laboratory I had some soil which had been producing wheat for forty-two years; for the last eleven years it has averaged twelve bushels to the acre. I obtained some other soils that had only been cropped for fire years and averaged 36 bushels to the acre. Those two soils were placed side by side. It is reasonable to suppose that the plant food was gone from the soil which had been cropped for forty-two years. but that in the new soil there was plant food. I had the idea that bacteria had something to do with them, so I took three pots of soil from the field that produced wheat for forty-two years. I put these pots in a soil oven and heated them to a boiling point. This was done to kill the bacteria. If I had put acid in the soil it would have killed the plant food. I took some virgin soil from the field which had been cropped for five years and planted these pots with wheat the same day, under the same conditions. When we harvested that wheat, the pots that came from the poor soil that had been sterilized had three and one-fourth times as much wheat as the pots which came from the gond soil. I didn't add a grain of fertilizer, but simply killed the bad hacteria in the soil and the plant was able to grow. In other words, the soil that had been cropped for forty-two years had beeome so contaminated with undesirable bacteria that the plant refused to grow good crops.

The time is coming. when a farmer will not go out into his field and supply artificial fertilizer, but will send to some laboratory and get certain germs that he can spread over his field and in that way produce results. One can put bad germs into the soil and the crops will refuse to grow; good germs can be put into poor soil and good crops will be produced. We are not the only ones that have been doing that. I can refer you to papers and reports from England and France that will verify my statement. It is not a question of what is in the soil or the plant food, but of the condition of the workmen who are making that food so that the plant can use it. Remember that it is not lime, phosphate and manure that make it all, but hacteria. If one can get rid of the undesirable workmen and put in skilled workmen he can get much better results. These workmen must have the raw material.

Now comes the next point. Why is the soil tilled? If the soil is hard and compact, this condition leads to the growth of bad work- 


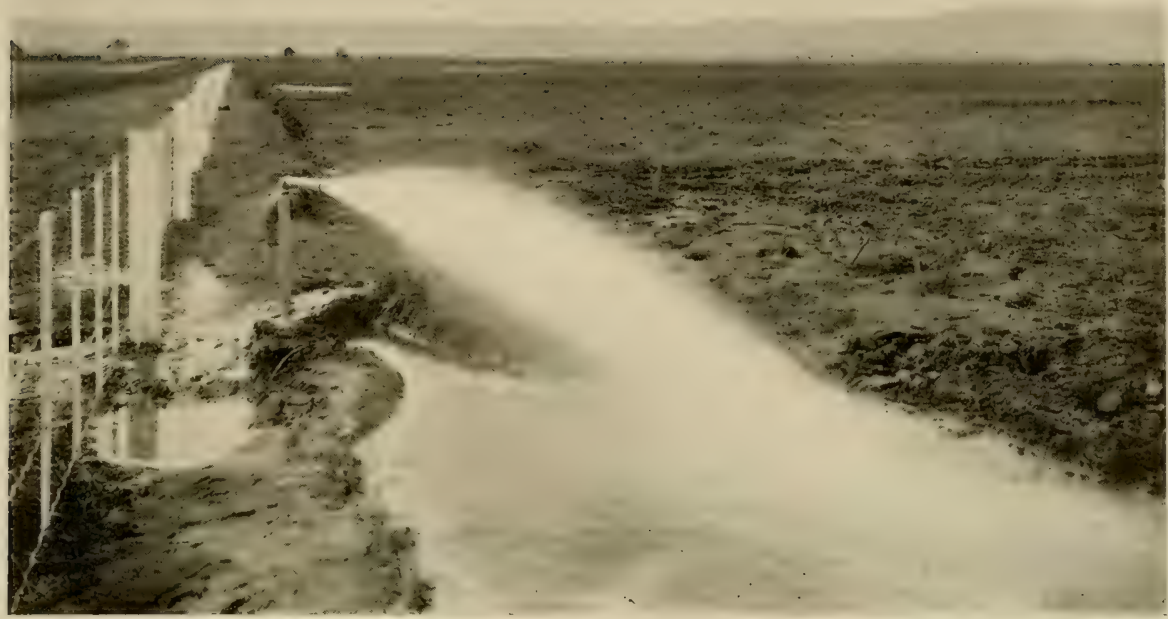

Irrigation as practiced in the Lewiston district, Idaho. Orchard land with young trees.

men. Bacteria are plants, very minute in size; they are not animals. They will grow under all sorts of conditions and materials, such as stumps, roots and branches. A plant will not grow in darkness, consequently it must have light; it must also have moisture. Plants cannot grow without food, consequently the bacteria must have food to live on. Think of this for a minute and you will see the reason for cultivating the soil and putting it into condition. Plants must also have air. If one tries to grow a tree where there is no air, it will die. It must have air, light, heat and moisture. Therefore we till the soil to bring about a condition necessary, not only for the plant above the ground, but more particularly for an ideal condition for these workmen that are so busy underneath the soil. If the soil is loosened up more air gets into it; it gets more sunlight, and holds more moisture. A soil that gets air, light and heat has greater bacterial action and more plant food is going to be mamfactured, especially for plant use. Hard material must be made soluble before a plant can use it. That is the purpose of the workmen. They take the raw material and make it soluble. Remember they cannot do this unless they have the raw material to work with.

If the soil in your orchard is in an undesirable condition your trees will not grow. How many of you have noticed that if potatoes are grown on the same patch for a number of years, the scab on the 
potato will soon get very bad and it will begin to rot, much more than if they had been grown on different patches? The same thing is true of wheat. These diseases are bacterial diseases. There are good and bad bacteria. These diseases are ealled parasite diseases. A parasite is an animal that lives on another, consequently one plant lives on another. There are diseases on nearly all the roots of plants as well as on the leaves.

There is a method of killing them, and that is by rotation of crops in between the trees, such as potatoes, clover or vegetables. You must divert your attention sometimes from the orchard itself to some other erop and introduce other bacteria that will compete with the undesirable bacteria. Clover when plowed under supplies the humus which is chiefly the food of these bacteria; that is, while they are working and putting these others into shape (potash. phosporic acid and lime), they are living on this humus.

You have read that humus must be put in the soil because we thought humus nourished the plant in some way, but we find that it does not nourish the plant so much. There is one point I want to state above all others. There must be plenty of humus in the soil. It is very desirable from the fact that it is a means of transporting moisture. It has heen said by possibly one of the greatest anthorities, Mr. F. H. King, that more crop failures were due from lack of moisture than from any other thing, and I heartily agree with him.

\section{Questions and Answers.}

Q. How can a badly run down farm that has been cropped for thirty years be built up?

A. First loosen up the soil to the depth of about eight inches, so that it will hold plenty of moisture, and make it possible for these bacteria to grow. After it is well loosened up put in a elover erop and plow it under.

Q. When you spoke of sterilizing the soil, didn't you kill the good bacteria with the bad?

A. I forgot to say that we added the good.

Q. Is there any benefit in adding better soil on top of the bad soil?

A. Possibly for a short time, but it would soon become inoculated with the bad bacteria again.

Q. For instance, if one were going to grow a clover crop wouldn't it be better to first inoculate the soil?

A. When starting clover on new land, inoculate the soil with the nodules of the old soil. 
Q. Is elover a better crop to plow under than vetch?

A. Vetch is also a legume, same kind of a plant. Peas are just the same. Peas, beans, vetch, alfalfa, clover, all belong to the same family and all serve the same purpose.

Q. How about ferns? Are they easy to raise?

A. We have found by analysis that ferns are almost as rich in nitrogen as alfalfa, consequently the fern would be a very good fertilizer, but is not as deep.

Q. Do these bacteria produce humus in the soil by cultivation of the soil?

A. They don't produce the humus; they lie on the humus and produce soluble forms. teria?

Q. How can one tell the difference between good and bad bac-

A. One can tell that they are present where crops are running down. For instance, where potatoes are grown for a number of years on the same soil there is a large percentage of scab. In order to get rid of this, stop that erop and grow some other.

Q. Is the color in red shot soil due to humus or is it due to iron?

A. It is due to iron.

Q. At what stage would you plow under alfalfa?

A. When it is sufficiently large for convenience. If it gets too large it is hard to plow under.

Q. What depth of soil should one have for planting an orehard?

A. Four or five feet will produce a good orchard. The deeper the soil the better.

Q. Is the north slope better than the south slope?

A. I believe the north slope is better for protection against frost. For color I prefer a south slope. 
(1)

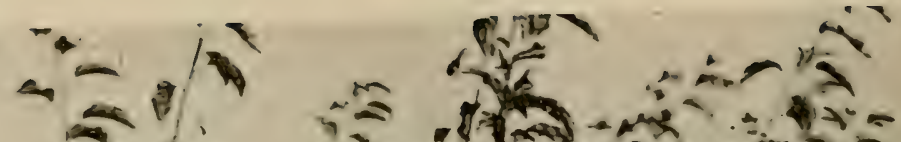

$$
\begin{aligned}
& \text { - a }
\end{aligned}
$$

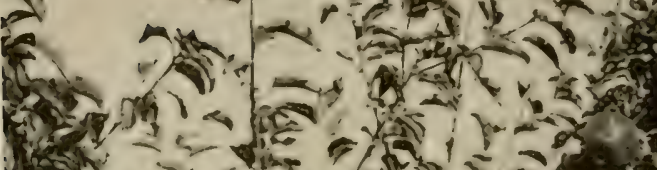
(2)

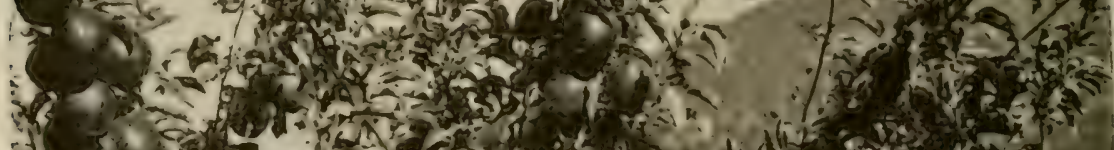

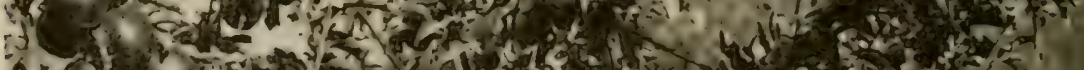

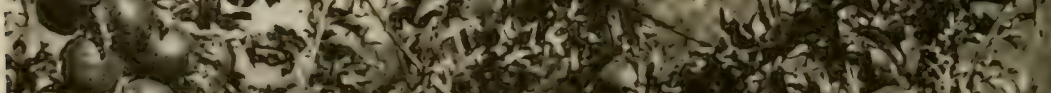

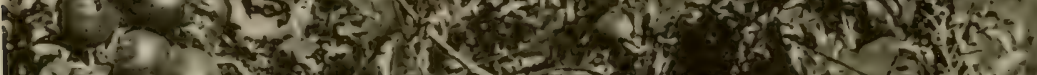

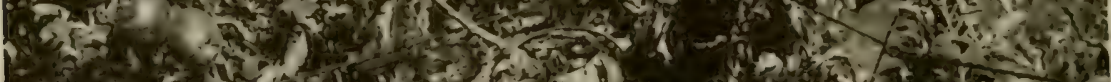
A. 1 (7) 2010 .

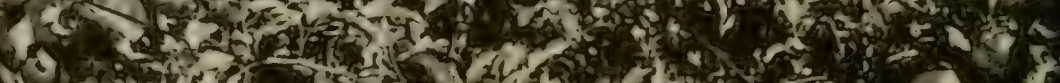

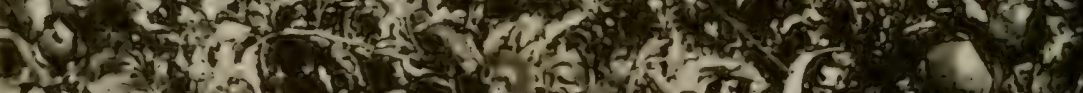

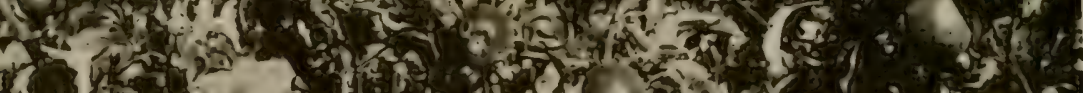

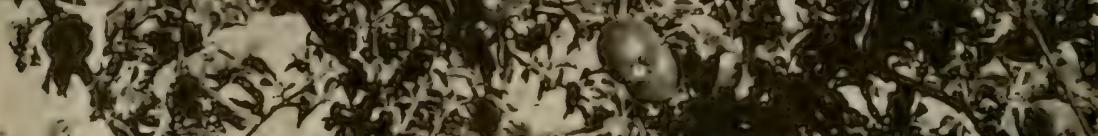

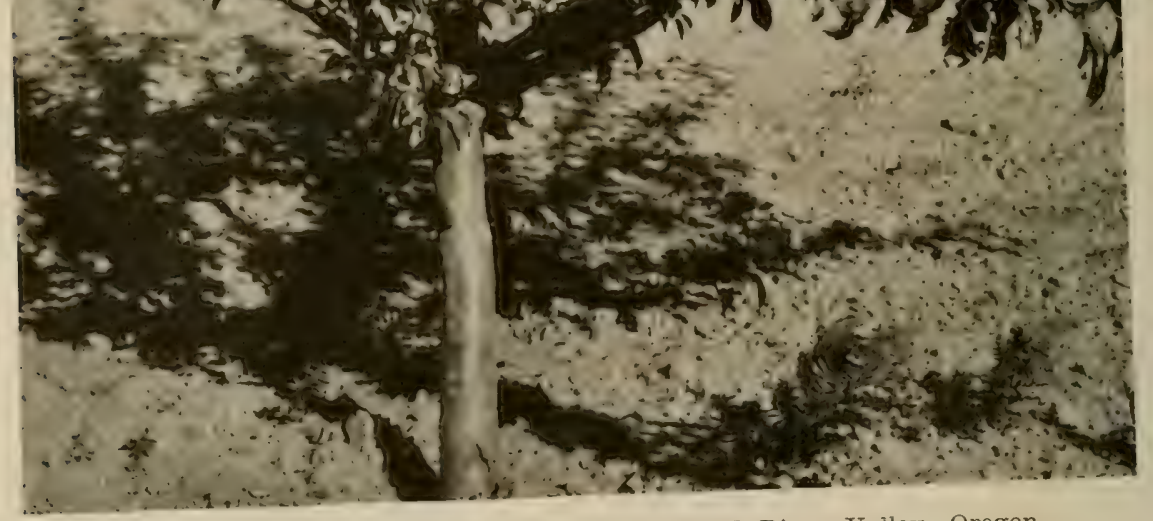
A four-year-old Spitzenberg Apple tree, Hood River Valley, Oregon. 


\title{
Varieties and Environment
}

\author{
C. I. Lewis, of the Oregon Agricultural College.
}

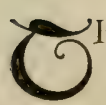

HE sulject of variety adaptation in each locality is a very dif-

ficult question. If one will stop a moment to think and analyze the conditions in this great state of Oregon, he will find that this is so. Take the rainfall for example; it varies from 23 to 130 inches. There are elevations from sea level to very high altitudes, and all sorts of soil. There are various exposures and great changes in climatic eonditions. There are more changes in this state than would probably be found in all the territory from the Atlantic seaboard to the Mississippi River. One can go out into a single locality and within a few miles find the rainfall cut in two, the elevation practically doubled and the soil absolutely different; so I have a very difficult problem on hand and need your help in this work. I hope to have two field men start work soon, and this will be one of their problems - "Variety and adaptability in the State of Oregon."

The popularity of a variety may be controlled by a number of factors, and may be divided into several heads :

First: Varieties that are popular because of their general scarcity, coupled with a fairly good quality. These include grape fruit, the Comice pear, and the Spitzenberg apple. At the present time the better type of grape fruit is sold for as high as 50 cents apiece, and it ceases to be a poor man's fruit. This is due partly to scareity, and perhaps, partly to fashion. The Spitzenberg apples bring a high price because of their rarity. The Comice pear brings a very high price largely on account of its scarcity, as well as on account of its good quality.

Second: By wide adaptability: the Concord grape, the Bartlett pear and the Baldwin apple. Take the Coneord grape, for instance; this has received the largest vote as being the best; then the Bartlett pear. Nearly everybody knows the Bartlett pear. It is the only pear grown under many different conditions, climatic and otherwise. The Baldwin apple is grown over a large area.

Third: By quality alone. Varieties may become popular because of their high quality. That stage has not been reached in America. The country is apt to go through several evolutions on such problems. Before the commereial days amateurs grew high-quality 


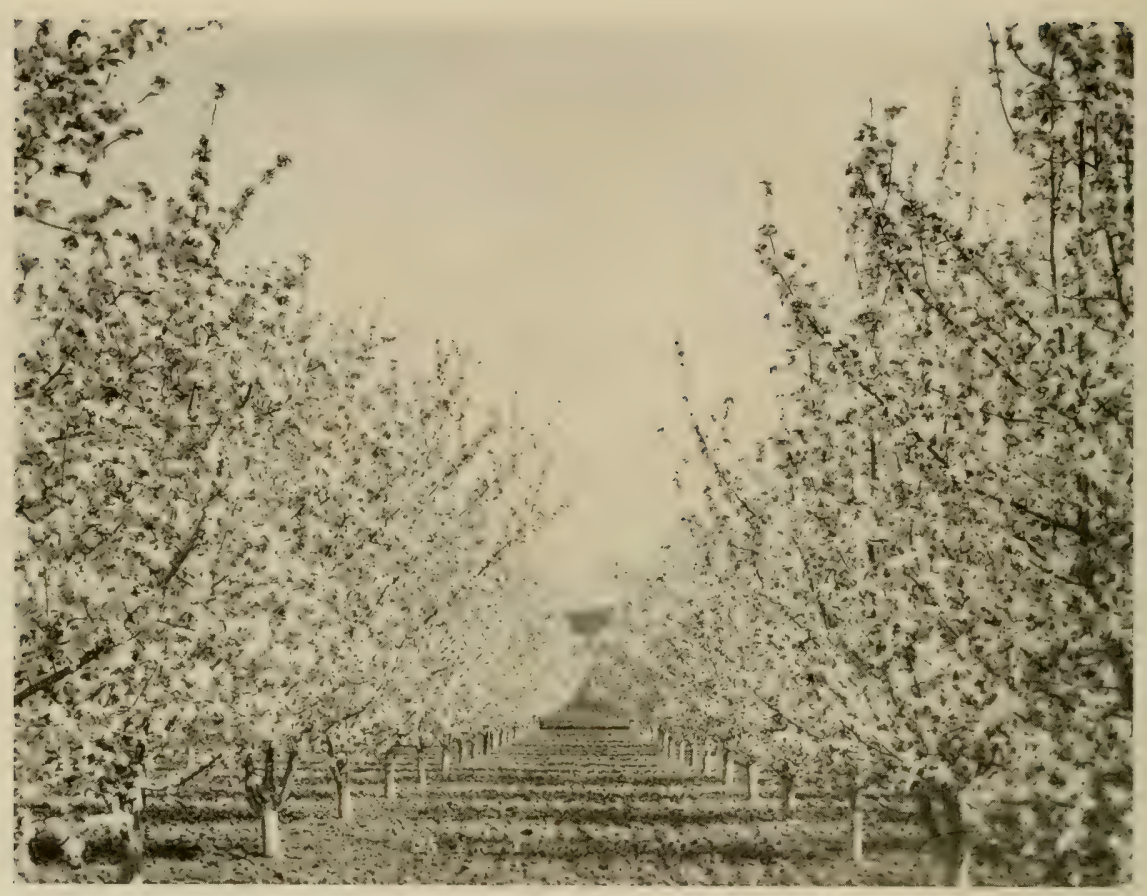

An apple orchard in full bloom, Yakima Valley, Washington.

fruit. Perhaps a little later, when the country becomes more populated, and there is more wealth, there will be a set of men in Oregon who will grow a good quality of fruit and the world will appreciate it. The degree of perfection of a variety is controlled largely by a combination of such factors as elevation, exposure, soil, general climatic conditions, and the skill of the grower.

The subject of variety adaptation in the Pacific Northwest is still in its infancy. Since the great acreage in orchards is still not in a bearing state, it will be some time before final conclusions can be adopted concerning the best varieties to grow under the various conritions to be found in each locality. There is a tendency in the state to plant in some cases too few varieties, or rather to try to adapt a very few varieties to all conditions. Among the principal varieties of apples is the Spitzenberg, one of the most popular. This is adapted to a deep, rich soil. This varicty is subject to all the troubles a tree is heir to, and needs constant nursing and careful handling. It is profitable only when grown to a high degree of perfection. The second and third grades of this variety are often a drag on the market.

The Jonathan is an apple of quite wide adaptability, but to be at its best it should develop a high degree of color. It needs careful 


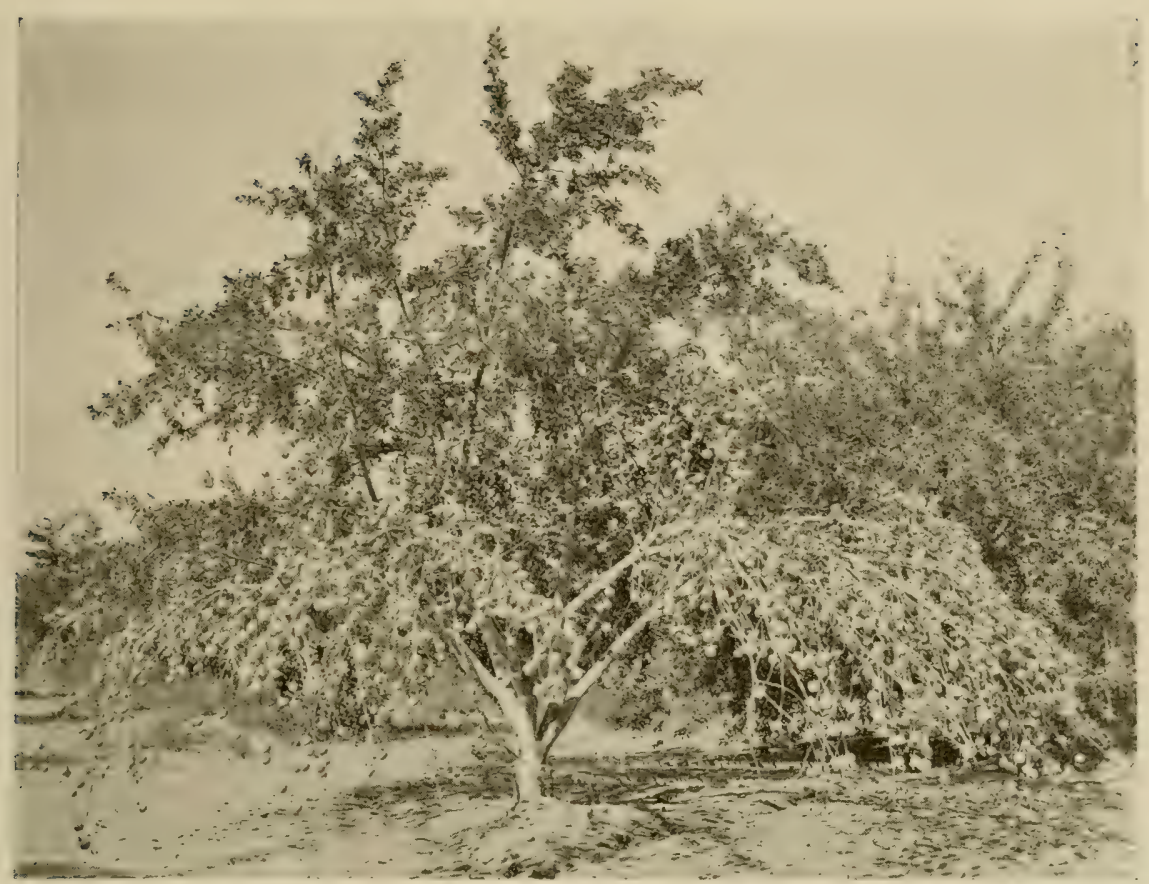

Yakima Valley, Washington, apple tree in full bearing.

handling at the time of picking, as it develops core rot and breaks down rapidly if allowed to hang on too long.

In most sections of the Northwest the Northern Spy is of rather poor quality, but some sections of the Willamette Valley have been especially successful in growing this variety. It should not be grown in too rich or too heavy soil, and rank growth should be discouraged by the use of summer pruning. It is a very desirable apple when highly colored and if not too large in size.

The Gravenstein is a very popular apple, and is becoming a fall product in most sections, like the IIood River Valley, the Willamette Valley and the Rogue River Valley. In some of the coast counties and in some of the uplands of Eastern Oregon it has long-keeping qualities. By careful picking the keeping season can be prolonged.

The King of Tompkins County has a tendency to over-grow and water at the core, but when grown to a high degree of perfection will find a ready market as a fall apple.

The Wagener is especially good as a filler and comes into bearing early.

The Gano is in some ways an improvement over the Ben Davis, 
having better color, and it is thought by many to be of superior quality, and, although it is a low-grade apple, it has been fairly profitable.

The Rome Beauty is rapidly becoming one of the leading apples for baking, and its popularity is steadily increasing throughout the state. As a rule it is profitable in most sections.

The York Imperial is grown to a considerable extent in the Grand Ronde Valley, but it has not been tried to any extent in other sections.

The Winesap is grown well to perfection in parts of Washington, but is grown sparingly in most Oregon districts. It has a tendency to grow undersize.

The Macintosh Red is grown but little in this state. As a highclass Christmas apple it would be adapted to the high elevations and to localities of the most severe weather conditions.

The Russian apples are usually adapted more or less to hardship and succeed on high elevations or exposures where others fail.

The Delicious has been grown very little in Oregon. As yet it is now only in the experimental stage. The same may be said of the King David.

Of the light-colored apples the Yellow Newtown is easily the leader. It has a wide adaptability and is now being grown to a high degree of perfection in the Hood River, Willamette and Umpqua Valleys.

The Ortley is a popular apple in the Hood River district. It is planted considerably with Yellow Newtowns as fillers and pollenizers. It is a high quality cooking and eating apple.

The Grimes Golden is increasing in popularity, especially in the Willamette Valley. It is a high-class apple, but at times grows rather small and has a tendency to drop badly; still. it is one of the most promising varieties.

The Winter Banana has as yet no commereial rating. I believe it is adapted to the higher elevations, similar to the mpper Hood River Valley, rather than to other sections of the state.

The White Winter Pearmain is grown splendidly in Oregon and is an apple of splendid vitality. It is a very good pollenizer with practically everything that has been tried, and in certain sections it should be tried more than at present.

The Rhode Island Greening is, where grown to a good degree of perfection, of good quality, and should receive more encouragement. It is successfully grown in Eastern Oregon and is increasing in popularity in some sections of the Willamette Valley.

As to pears, it is the general belief that varieties like the Bartlett, Comice and Bosc are grown to a higher degree of perfection on light rather than heavy soils. Whether they will keep as well when grown 
on such soils is a question still to be investigated. Where it has been reported that they have not kept as well when grown in such conditions, it may have been due to the fact that the crop was prepared in regions having only light soil against regions which had both light and heavy soils.

The Comice is being grown in larger quantities than is justified. While it is, when grown to a high degree of perfection, a high-priced pear, it is a shy bearer, eomes into bearing late and is not as much of a money maker as other varieties. The Bartlett and the Anjou are steadily increasing in popularity.

The Winter Nelis should be planted only on the richest soils.

Pear districts should try varieties not very commonly grown. Select the Glou Morceau, Patrick Barry, Berre Hardy, etc.

As a guide for the proper selection of varieties of fruits for different localities I have prepared a list which might be foltowed with advantage.

\section{Varieties of Fruits for Various Localities.}

For the lower altitudes of, Wasco, Mroro, Crook, Gilliam, Sherman, and Umatilla counties, the selection can be made from the following varieties :

Apples-Yellow Transparent, Gravenstein, Jonathan, Winesap, Rome Beauty, Wagener and Ben Davis; the latter for spring use.

Pears-Practically any commercial variety, including Bartlett, Clapp's Favorite, Seckel, Anjou, Winter Nelis.

Cherries-Lambert, Royal Anne and Bing, for sweet cherries. Early Richmond, English IIorello and Olivette for sour cherries.

Prunes and Plums-Use any of the standard varieties such as Italian, Hungarian and Peach Plum.

Peaches-Alexander, Early and Late Crawford and Lemon Cling.

Grape-European varieties are generally covered to be protected in winter. They are such as Black Hamburg, Muscat. Rose of Peru and Tokay. American varieties are: Worden, Concord. Niagara and Deláware.

Strawberries-Clark's seedling is the best. Practically any of the early, medium or late varieties would give a good family supply.

Raspberries-Cuthbert, Gregg, Marlboro and Cumberland.

Blackberries-Lawton, Eldorado and Kittatinny.

Currants-Fay, Cherry and White Grape.

Gooseberries-Red Jacket, Champion and Industry.

For the lower elevations of Union, Baker and Wallowa counties, the following varieties are found to be the best adapted: 
Apples-Yellow Transparent, Gravenstein, King. Jonathan, Rome Beauty, York Imperial.

Pears-Bartlett, Clapp's Favorite and Anjou.

Cherries-Lambert and Bing, for sweet cherries; Early Fichmond and Olivette, for sour cherries.

Prunes and Plums-Italian and Hungarian.

Peaches-Any of the early varieties, such as Early Crawfords, Hale's Hardy, Alexander, ete.

Grapes-Worden, Concord, Niagara and Brighton.

Strawberries-Clark's Seedling, Sharpless and Magoon.

Currants-Fay, White Grape.

Gooseberries-Red Jacket, Industry and Champion.

The higher (levations of Eastern Oregon suffer more or less from the severity of winter and drouth in summer, and the same care in the selection of varieties should be exercised.

Apples-The Russian varieties will be the hardiest. These varieties in low altitudes are summer and fall varieties, but often in high altitudes they are long keepers. Red istrachan, Gravenstein, Duchess. Tolf River, Wagener and Macintosh Red are the hest and most satisfactory to plant. Occasionally nearly any of the stantared varieties grow suficiently well for family use. Varieties of some promise in such sections are Rome Beauty. White Winter Pearmain, Delicions and Gano.

Pears-White Doyanne, Seckle, Clapp's Favorite.

Peaches-Peaches as a rule should not be grown in the higher elevations of Eastern Oregon, but oceasionally such varieties as Alexander and Amsden do very well. The Gobh's apricot is often successful.

Cherries-Lambert and Bing for sweet. and the Early Richmon? and Olivette for sour.

Raspberries-Cuthbert and Turner's Red.

Blackberries-Any of the standard varieties, such as Kittatinny, Lawton and Eldorado.

Gooseberries-Red Jacket and Champion.

Strawberries-Clark's Seedling, Warfield and Bederwood.

\section{Varieties for Hood River.}

The varities considered best for Hood River are:

Apples-Yellow Newtown, Spitzenberg, Ortley, Jonathan, Red Cheek, Arkansas Black.

Pears-Anjou is the leading variety, and seems to grow well. Other varieties worth trying would be the Bartlett and Patrick Barry.

The varieties at Mosier are similar to those at Hood River. Very 


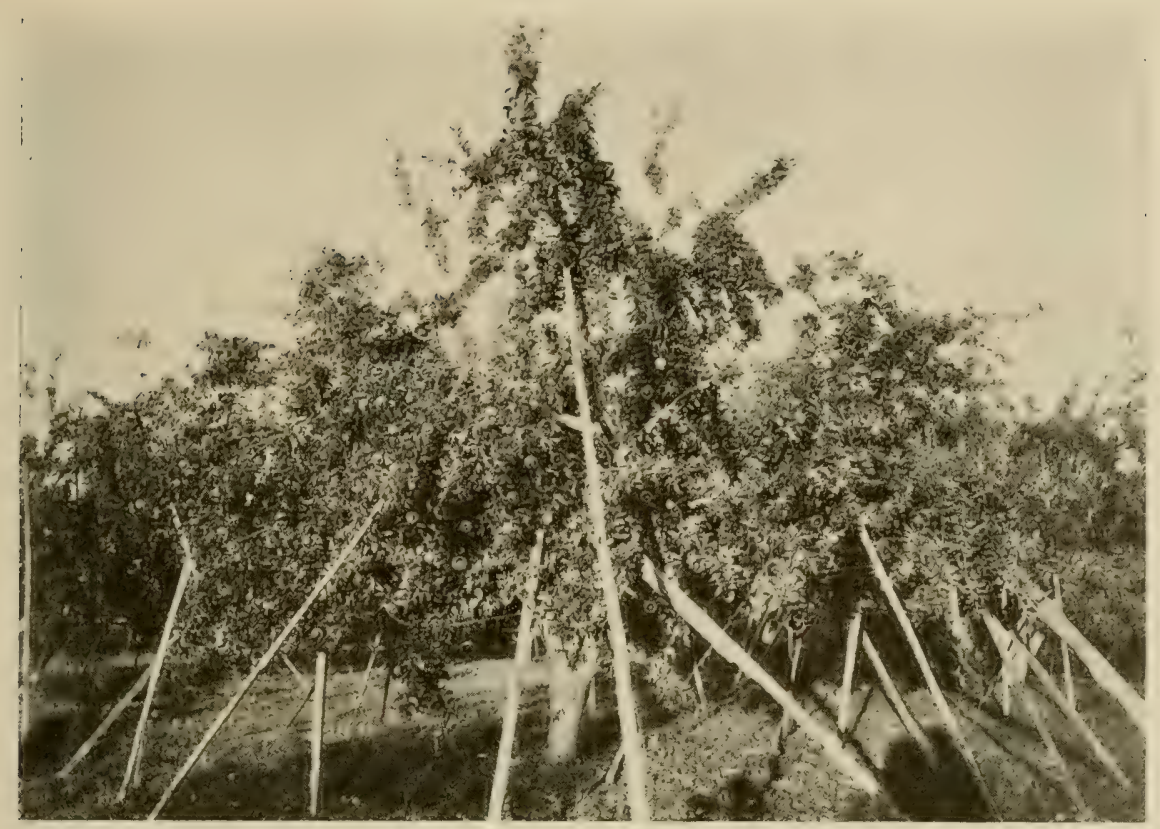

Apple tree, Rogue River Valley, Oregon. This photo took first prize at the National Apple Show at Spokane for the best photograph of a single apple tree.

few other fruits are grown in this district.

Raspberries-Cuthbert.

Strawberries-Clark's Seedling.

In the upper Hood River Valley it is still in an experimental stage. The Winter Banana seems to do well, and it may be that the Delicious will be good for that district, also the Jonathan, Gano, etc.

In the vicinity of The Dalles we find a district especially adapted to peaches, prunes, cherries and grapes. The district above The Dalles is being cultivated to apples, varieties of which are given in a list attached hereto.

For peaches, the principal ones are Early Crawford, Late Crawford, Salway, Elberta, Muir, Orange and Lemon Cling.

For cherries, such as the Bing and the Lambert do well.

For grapes, such varieties as the Tokay and Muscat are growing well.

\section{Willamette Valley.}

One of the hardest valleys upon which to give advice as to the variety of fruit, due to the large area of the valley and the many varied conditions found, and owing, also, to the fact that, with ap- 
ples especially the industry is still in its infancy, is the Willamette Valley.

Apples-Yellow Newtown, Jonathan, Grimes Golden, Rome Beauty, Gano, Rhode Island Greening, Gravenstein, Ortley, Wagenex, Spitzenberg and Vanderpool Red.

Pears-Bartlett, d'Anjou, Comice, Patrick Barry and Clairgeau; and worthy of trial are the Glon MLorcean, Beurre IIardy, Rode and Howell.

Peaches-Early Alexander, Amsten June,. Waterloo, Triumph, Early Columbia, Hale's Early, Mamie Ross. Lovell, Champion, Early Crawford, Early Charlotte, Tusean Cling, Golden Cling, 1Inir, Late Crawford, Elberta, Globe, Fitzgerald, Salway. These varities are named in their fruiting order. Some of the most promising in this list are the Amsden . June, Early Crawford, Early Charlotte. Mamie Ross, Muir, Elberta, Globe and Salway.

Prunes-The Italian.

Plums-The Peach Plum and the Satsuma. The Maynard is a good home plum.

Cherries-Royal Anne, Bing and Lambert for sweet cherries; the Olivette, Montmorency and Early Richmond for sour cherries; and May Duke and Late Duke, which are especially fine for local cherries.

Walnuts-Franquette, Mayette and Maylan.

Grapes-Worden, Coneord, Niagara, Delaware, Breighton.

Such fruts as apricots and almonds should be grown sparingly in this valley.

Red Raspberries-Cuthbert, Marlboro, Superlative Antwerp.

Black Raspberries-Cumberland and Gregg.

Blackberries-Evergreen, Snyder and Mammoth.

Gooseberries-The Oregon, Downing, Industry and Smith.

Currants-Perfection, Fay, Victoria and White Grape.

Strawberries-Gold Dollar, Sixteen to One. Magoon and Clark's Seedling. Also the Autumn Bell.

\section{Umpqua Valley.}

The prineipal apples grown are the Yellow Newtown, Spitzenberg and Jonathan. Pears have been planted as yet hut sparingly. Bartlett, Anjou and the Comice are in the lead. As this district is very early, more of the early types of cherries, pears, apples and peaches should be grown than at present. These would find a local trade throughout the Northwest. The leading cherries are the Royal Anne, Lambert, Olivette, Montmoreney, Early Richmond, Early Purple and Guiype. 
For small fruits in this distriet I would advise:

Strawberries-Gold Dollar, Ever Bearing, etc., while the Clark's Seedling, Magoon, Sixteen to One, ete, will thrive.

Grapes-Worden, Concord, Delaware, Breighton. Possibly in some of the sections a few of the European grapes. like the Mruscat and Tokay will thrive.

\section{Rogue River Valley.}

Apples-Yeilow Newtown, Spitzenberg, Jonathan, Winesap.

Pears-Bartlett, Anjou, Comice, Howell, Winter Nellis, Bose are commonly grown. Such varieties as Glou Morceau, Patrick Barry, Beaurre Hardy are worthy of trial.

Cherries-Lambert, Royal Anne, Olivette, Montmorency, Early Richmond, May Duke and Late Duke.

Grapes-Muscat, Tokay, Thompson Seedless, Worden, Concord and Delaware.

Peaches-Practically all the commercial varieties thrive in this district.

Prunes-Few prunes are grown except for local consumption, such varieties being the Italian and the Petite.

Apricots-Royal and Tilton are the leading varieties.

Almonds-Soft Shell, I. X. L., Languedoe and Drake's Seedling. The Texas Prolific is recommended as worthy of trial.

\section{Coast Countries.}

All the varieties of small fruits seem to grow to a high degree of perfection in these coast countries. Most of the pomoceous fruits are still in the experimental stage. Locations should be chosen that are not exposed to the strong ocean winds. The Gravenstein is supposed to be one of the finest apples in these sections. Quite a number of our commereial varieties are growing to a fair legree of perfection.

Peaches, cherries and grapes as a rule will probably only grow for home consumption.

\section{Dwarf Fruits.}

Before concluding, I should like to say a word on the subject of dwarf fruits. The dwarf fruit as a commercial proposition is still in an experimental condition in this state, but the dwarf pear looks quite promising to be used in plantings by itself or to be used as a filler. There is one pear orchard in Idaho, and a number in this state, but few are bearing as yet. The trees can be planted close together. 


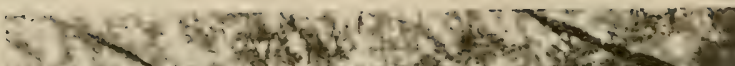

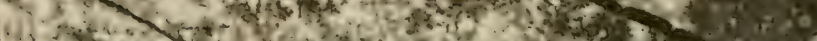

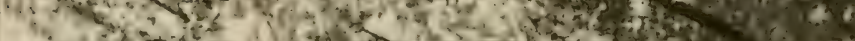

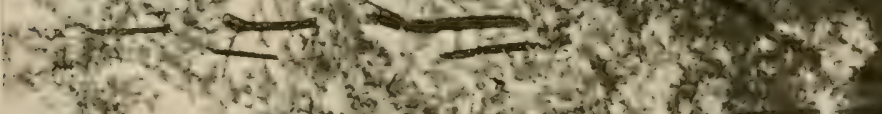

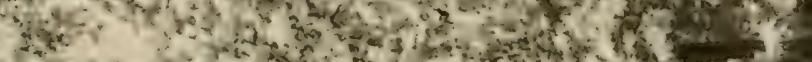

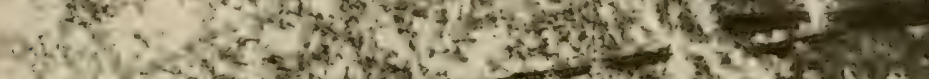

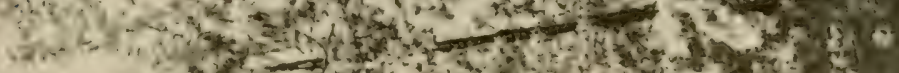

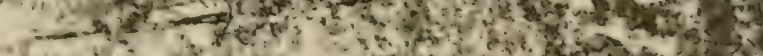



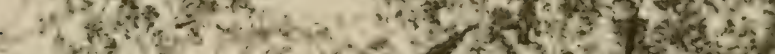


Q

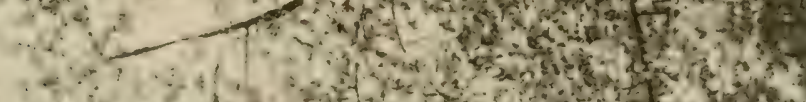

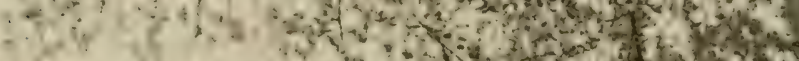

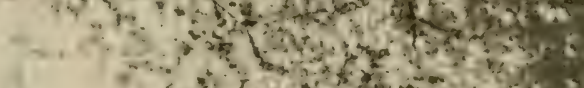

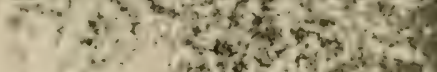
$\therefore$ and 4. thes: in thats s ofe.

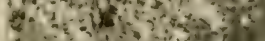
is $x^{2}$ in 320 - 1905 $r$

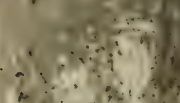
$2 \times 1 x^{3}=$ $\therefore$ Non tos (5) $+42-10 y$.

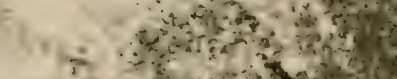

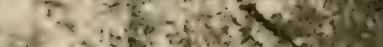



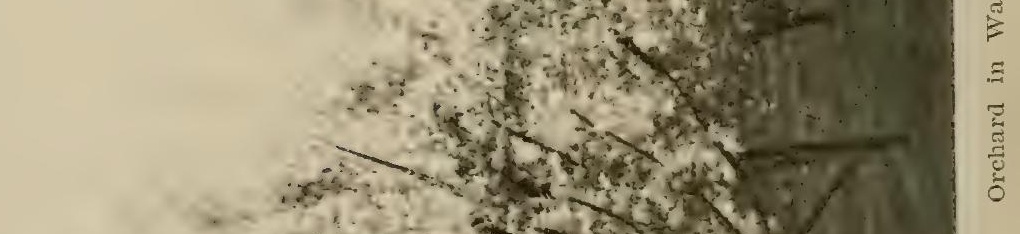

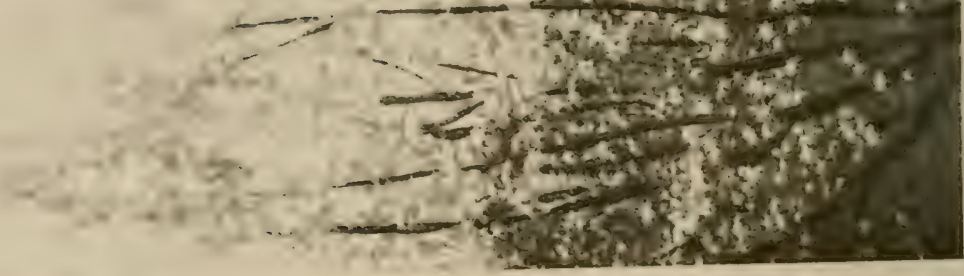

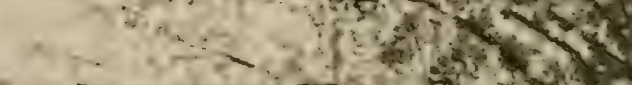



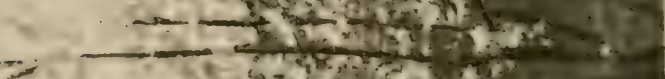


They come into early bearing, and generally produce a fine crop. They are generally worked on Angers Quince or Portuguese stock, and then worked over to Duchess or Koonce, and finally they are worked over to whatever variety is desired.

The dwarf is obtained by using a root that is slow growing, and then pruning. Pruning should be done in such a way as to throw out the laterals and spurs. Summer pruning is practiced much more with the dwarf stock than with the standard.

Dwarf peaches are also being grown, and come into bearing quite heavily the first year. There are several plantings in our state, and it will only be a short time before we will know more of these.

The dwarf apple has been tried very sparingly. When it is put on Paradise stock it is more of a curiosity, but when planted on the Doucin stock it may make a satisfactory tree for Western Oregon.

The divarf fruit offers a splendid opportunity for a home garden and a good conservative field for trial in the commereial orchard.

\section{Questions and Answers.}

Q. How about the King David apple?

A. To my knowledge it has been grown sparingly in any section. I saw one box at Hood River and another at the National Fruit Show. It is still purely experimental and seems to be at its best in Eastern Washington. As to adaptability, would say go at it gradually.

Q. Are many Rambo apples grown?

A. Some of the commercial orchards grow a few. In an orchard I own myself there are two Rambo trees 7 years old this year; very heavily grown, first-class. They are encouraging from that point of view.

Q. Is it too late in the season to plant apples or cherries?

A. It is a little too late for cherries; and by planting apples now one would be losing just so much money. Apples to be at their best should be planted before this time, but should there be a wet April it would make little difference. In most parts of the state apples should be planted about the middle of Mareh. If you haven't ordered your trees, wait until fall and get your order in early.

Q. Is the Northern Spy a late bearer?

A. Yes, it comes into bearing very late, but by proper summer pruning and intense cultivation one can to some extent overeome that. I have 10 acres myself, and think I can reduce the time considerably. If I could grow as high-class apples as my neighbor, Armstrong, I would be well satisfied. There is very little winter pruning done on the Northern Spy. 
Q. Would you try that method on any other variety than the Northern Spy?

A. Do not try it on the Jonathan or the Wagener. They come into bearing about the fifth year. Encourage the Northern Spy and the Yellow Newtown. I find in most cases that they are orer-prumed. They head in too much and the Yellow Newtown fills out lacking growth.

Q. Would you recommend the variety system in planting an orchard?

A. INot very much. In my talk here last fall I remember coming across a man who grew quite a variety. It can be done all right. In fact, there are several such old orchards and some of them are worth as high as $\$ 2,000$ an acre. Of course they wouldn't be worth that in four or five years mless rery highly cultivated. When at Payette, Idaho, three years ago. I saw an orchard where there were four rows of dwarfs a quarter of a mile long, and the owner told me that if he were planting again he would plant nothing but dwarfs. Steve Hamilton, of Bashaw. Wash., made quite a success of growing dwarfs. IIe is very enthusiastic about them. Tle has a fine grade of pears from 3year-old trees this summer.

Q. Are dwarf trees as long lived as other trees?

A. Under some conditions there is not much difference. In Japan there are trees centuries old.

Q. How many varieties of apples would you have in an orchard?

A. Not over three.

Q. How about the soil for cherries?

A. The soil in the locality of Mosier is very good. They do the best on deep rolling soil where there is good drainage. There is a bright future here in the Northwest for cherry growing, and I don't know why more people are not interested in cherries. Willamette cherries as a shipping proposition are very inviting at the present time. I don't know why more people don't engage in prune growing. When one stops to consider the value of land, and what it costs to produce trees and grow a crop, it is the best proposition in the Northwest. While pears prohahly pay as much as anything else. they require more skill, but the prume industry has now come to a point where it is very profitable. There are prune men in Oregon who are making an average of a hundred dollars an acre a year. A 40 -acre prune orchard can be handled as easily as a 10 -acre apple orchard.

Q. Do you consider the Lambert a good shipping cherry?

A. Yes, there is no question that they can be shipped from all over this state. They have been shipped to New York in splendid condition. When we get large areas handling cherries, so that they can be shipped in carload lots and can be handled quickly for commereial 
purposes, there is going to be a bright future here for the cherry industry. We have the entire country as a market, as California cherries are practically off the market when ours come in.

Q. When does the Lambert cherry ripen?

A. Last year, about the 8th or 10th of July.

Q. What elevation is best for cherry-growing?

A. I am inclined to think they can be grown best on an elevation of 1,000 or 1,200 feet. Such an elevation would bring into bearing and cause them to ripen earlier than a lower elevation. Cherry-growing is a very encouraging industry on some of the tablelands. Don't. put them in heavy, wet, solid soils, as they will die. When put on suitable soil there will be less of that so-called gumming. Many cherry trees die from lack of proper care. There is a foolish notion that they must not be pruned or cultivated.

Q. Why is it that the Royal Anne cherry is more subject to gumming than others?

A. I havn't observed that it is.

Q. How is the Bing cherry for shipping?

A. It is fine, especially at The Dalles, and in this valley it seems to be good.

Q. How about prunegrowing in the Umpqua Valley?

A. There is not much doing just now. They used to grow Petites there, but the industry does not seem to advance much in that valley.

\section{Historical Notes.}

(As given in "The Apples of New York," by Beach.)

\section{Spitzenberg.}

Spitzenberg-Originated at.Esopus, Ulster County, New York. We find no authentic account of the date of its origin, but it is seattered throughout the state in the oldest orchards, and was known in Eastern States more than a century ago. It is known in eultivation in Europe, and is one of the recognized commercial varieties in certain apple-growing districts of the Rocky MIountain region, Washington and Oregon.

\section{Yellow Newtown.}

Yellow Newtown-The "Newtown. Pippin"' was the first American apple which attracted attention in Europe. After the receipt of specimens by Franklin while in London in 1759, and the subsequent sending of grafts to Collinson by John Bartram, numerous attempts were made 
to grow the variety in England. As early as 1768 it was eultivated. in the Brompton Park nursery under the name "Newtown Pippin of New York."

It is probable that the large apple exports of 1773 included considerable quantities of the Newtown, for it was at that time quite generally distributed through the apple-growing districts of the Atlantic slope. Thomas Jefferson recorded in his "Garden Book" that in March, 1773, grafts of "Newtown Pippin" received from MIordecai Debnam, at Sandy Point, were "ingrafted by P. Morton," and in Narch, 1778, he noted that the grafted trees were planted out at MIonticello.

Prior to 1803 Forsyth said of the rariety in England, "The Newtown Pippin is a fine apple in good season, but seldom ripens with us. It is held in great esteem in America." MIcMahon, in 1808, included Newtown Pippin in his select list of "long-keeping apples," and also in a list of "cider apples."

Previous to 1817 we have no record that more than one type of the Newtown was recognized, but Coxe, whose work appeared in that year, deseribed as distinct varieties the "Large Yelloy Newtown Pippin" and the "Green Newtown Pippin," characterizing the latter as "a variety of the preceding kind." Since the time of Coxe the two types have been recognized as distinct by our leading American pomologists, though fruitgrowers are by no means unanimous on this point.

The original seedling tree of Newtown Pippin is alleged to have stood near a swamp on the estate of Gershom Moore, in Newtown, Long Island, until about 1905, when it died from excessive eutting of scions and exhaustion. Its origin is credited to the early part of the eighteenth century. It is not clear at this time whether the original tree was of the "green" or "yellow" type, nor has any record of a distinct origin of the two been discovered.

Though first grown in commercial orchards in New York, New Jersey and Pennsylvania, the excellent quality of the fruit from some of the Potomac counties of Virginia was noted as early as the time of Coxe.

In Albemarle county, Virginia, where it reached a high degree of perfection, it hecame known as the "Albemarle Pippin" at an early" day, and was for many years considered a distinct variety of local origin, and was so propagated.

An export trade in the fruit from Albemarle county was inaugurated under favorable auspices by a happy circumstance which occurred in the first year of the reign of Queen Victoria.

The identity of Albemarle and Yellow Newtown seems to have been recorded first by the late Franklin Davis in a letter from Stamn- 


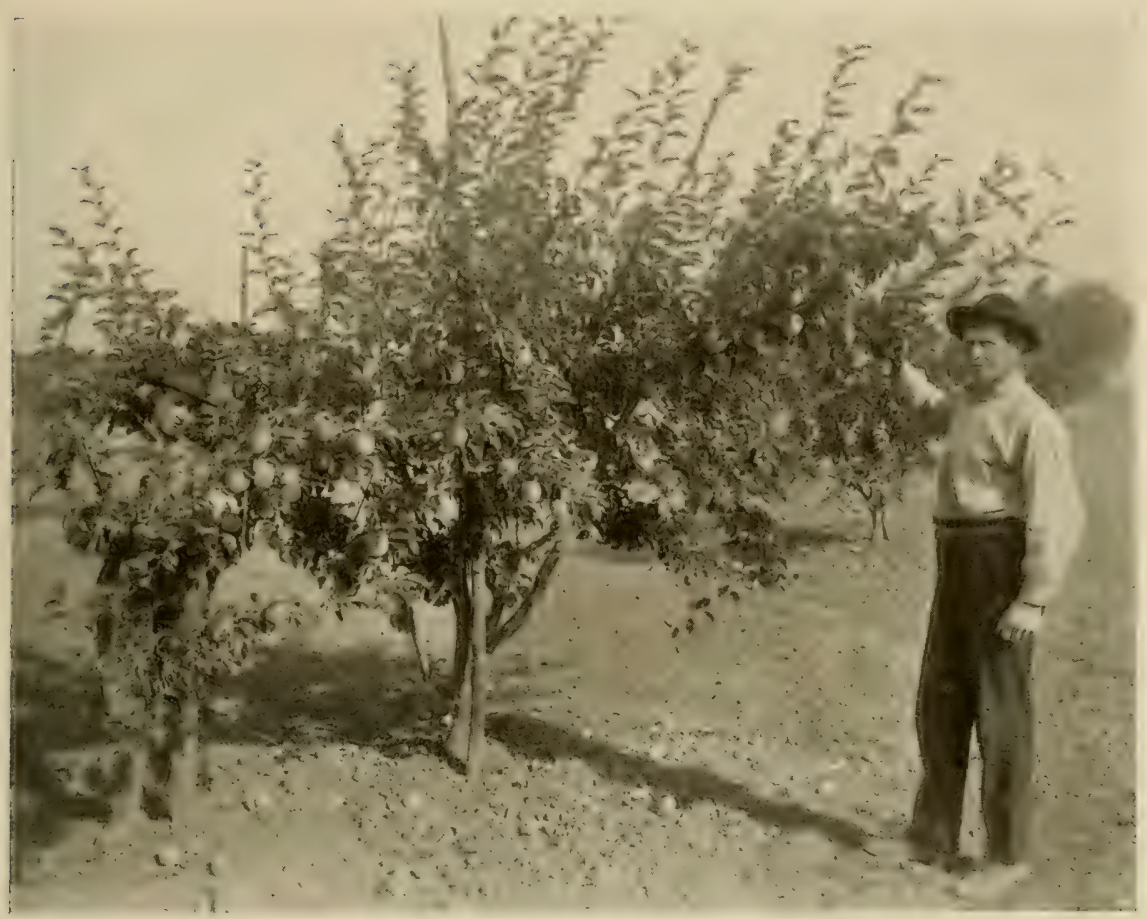

Toung apple tree in The Dalles district, Oregon. Note method of propping up the limbs, which originated in this district.

ton. Va., which was published in the Horticulturist in 1857. Since that time most pomologists have accepted their identity, ascribing the slight variations which are observable to local soil or climatic conditions. But in the absence of an authentic record of the introduction of Yellow Newtown to Albemarle county, many orehardists in the Piedmont and mountain regions have continned to believe in the Albemarle as a distinct variety of local origin. Recent investigation by Messrs. H. L. Lyman and Samuel B. Woods, prominent citizens and fruit-growers of Charlottsville, Va., have resulted in an apparent clearing up of the historical uncertainty and establishing a clear connection between the supposed original Albemarle tree and the older variety.

The Yellow Newtown has for many years been considered the better apple for exportation, however, and in commercial orchards has almost superseded the Green Newtown on account of its larger size, brighter color, and hetter keeping quality. Both sorts are exceedingly variable and susceptible to the influence of soil, climate, elevation above sea level, etc. They are successfully grown in but fer portions of the 
apple-producing area of the United States at the present time, the principal localities being the lower portion of the IHulson River Valley in New York, the Piedmont and mountain regions of Virginia anci North Carolina, and portions of California, Oregon and Washington.

\section{Northern Spy.}

Northern Spy-Originated in a seedling orchard at East Bloon: field, N. Y., which is famous for the production of this variety, the Early Joe and the Melon. This orchard was planted by IIerman Chapin with seedling trees grown from seeds brought from Salisbury, Conn., about the year 1800. Sprouts from the original tree were talien up and planted by Roswell Humphrey and by him the first fruit of the Northern Spy was raised as the original tree lied before bearing. In 1847 nine of the trees set out by IImmphrey wre still living. The variety was confined to the vicinity of its origin for many years, and it was not until about 1840 that it began to attract the attention of fruitgrowers in other localities. Its great value then eame to be more widely recognized and in 1852 the American Pomological Society not only listed it as a variety of promise, but also as a variety worthy of general cultivation. Since that time it has become extensively planted, not only in New York, but in various other portions of the more northern apple-growing regions.

\section{Ortley.}

Ortley-This is an old New Jersey variety which. Coxe described under the name Woolman's Long Pippin. In 1825 Floy sent fruit of it to the Royal Horticultural Society, London, under the name of Ortley, and in the transactions of that society for that year Lindley described it under this name, giving Woolman's Long as a synonym. Kenrick Manning, 'Thomas Elliott, Charles Downing and other American Pomologists, have followed Floy instead of Coxe and described the variety under the name of Ortley. Emmons gives Ortley as identical with Warren Pippin of Coxe, but it is quite doubtful whether he was correct in this case. In portions of the South and West Ortley is an old favorite for planting in home orchards, and has there been known under many different names prominent among which are White Belleflower and White Detroit.

\section{Ben Davis.}

Ben Davis-The origin of this apple will probably never de definitely known. It has been varionsly credited t: Temmessee, Kentuck! 
and Tirginia. It is supposed to have originated about the beginning of the last century. This view is supported by the fact that before the Civil War it had spread throughout the states just mentioned, and following the rontes of migration had been carried into southern Indiana, Illinois and generally disseminated throughout Missouri and Arkansas. Downing does not mention it in his first edition, but it is described in the first revision of his book on "The Fruits and Fruit Trees of America." Warder refers to it as a comparatively new sort in Ohio and the Northwest, but common in the South and Southwest. During the last quarter century it has been disseminated extensively through all the apple-growing portions of the United States.

\section{Gano.}

Gano-Origin obseure. Brought to notice in Missouri about 25 years ago and disseminated under the name Gano. It is supposed by some that the original stock came from Kentucky. Some believe that Gano is the same as Black Ben Davis. It certainly resembles Black Ben Davis very closely, but the preponderance of evidence at present seems to favor the opinion that it is of distinct origin.

\section{Rhode Island Greening.}

Rhode Islamd: Greening-The locality of the origin of the Rhode Island Greening is not known with certainty, but there is little reason to doubt that it originated in the state of Rhode Island and probably in the vicinity of Newport, near the place now known as Green's End, where, in olden times, there was a tavern kept by Mr. Green, who raised apple trees from seed. Among the trees thus produced was one which bore a large green apple. The scious of this tree were in such demand by the people who stopped there as guests that the tree died from excessive cutting and exhaustion. The fruit which resulted from grafting with scions was known by different names-in Rhode Island as the "Apple from Green's Inn," while in adjoining states it was called the "Green's Inn apple from Rhode Island." In the town of Foster, upon the farm of Thomas R. Drowne, at Mount Hygeia, stands an old Rhode Island Greening tree, which is supposed: to be nearly 200 years old. This, to the knowledge of the members of the family now living, has borne uninterruptedly until within a few years. On the farm of Frederick W. Winslow, a few rods southwest of the lime kiln on the northern verge of Fruit Hill, stands a Rhode Island Greening tree, which is locally known as the "Daughter Tree." This tree is a limb of the mother tree, which was broken off in the September. 
gale of 1815 , and which, upon being thrust into the rich moist soil, took root and became an independent tree. The mother tree was planted in 1748 . It was, therefore, 141 rears old when it was cut down in 1889. Anthentic records of trees of this variety that were planted about 150 years ago in the soil of North Providence on the farm of the late Lemuel Angell, are still in possession of that family. It was introduced into the old Plymouth colony from Nerport in 1765 ; from there it was carried into Ohio in 1796 by General Putnam.

While we have no record of its earliest introduction into this state, it is well known that Rhode Island Greening was pretty widely disseminated in the older settled regions of New York during the 18th century. It is often found in the oldest orchards now in existence in New York, and also ranks as one of the most important varieties in recently planted orchards.

\section{Grimes Golden.}

Grimes Golden-Originated in West Virginia. Fruit from the original tree was sold to the New Orleans traders as long ago as 1804 . It has become generally disseminated throughout the Ben Davis regions of the South. West and Sonthwest, where it is often planted for home use and is highly esteemed as a dessert apple. but it is not grown in many localities in the commercial orchards. It has long been known in scattering localities in New York and old trees of it are found in some orchards, but it has not been generally planted.

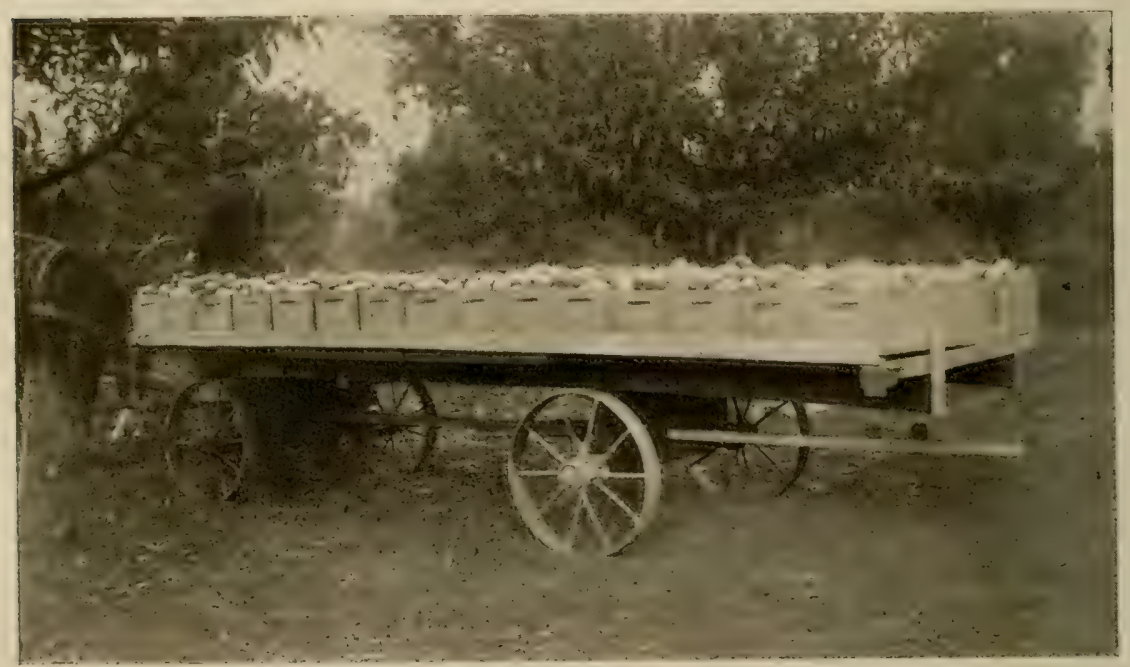

Apple wagon in one of the big vrchards of Oregon. 


\section{Wagener.}

Wagener-The first published reference to the Wagener which we find is that given in the report of the New York State Agricultural Society for $18 \pm 7$, in which it was stated that it was awarded secoml premium as a seedling of merit. In 1848 it was again presented for competition and was placed by the committee in the list of first-class apples, awarded an additional premium and also a diploma. An illustrated deseription of it was published in the report of this socicty for that year, with the remark, "This very fine apple the committee consider a desirable addition to the list of first-rate fruits. Its appearance is prepossessing, as is also its size and form." An account of the history of the Wagener was also given, in which it was stated that in the spring of 1791, Mr. George Wheeler brought with him from Dover, Dutchess county, New York, to Penn Yan, Yates county, a quantity of apple seeds which he sowed that spring in the musery upon his farm which he was then reclaiming from the wildrmess. In 1795 Abraham Wagener, from whom the name of the apple is derived, bought this seedling nursery and planted trees from it upon his place, in what is now the village of Penn Yan. In 1848 it was remarked that the old tree was produeing an annual and abundant yield of beautiful and delicious fruit. It continued to bear full crops till about the year 1865. After it was brought to the notice of the State Agricultural Society the Wagener soon began to be propagated quite extensively, and it has since become widely disseminated throughout the country. In 1892 the Wagener was being offered quite generally by nurserymen throughout the country, except in the North Mississippi Valley, the Rocky Mountain region, and the plains from Nebraska to Texas. It is generally known throughout New York but is not planted extensively in any section of the state.

\section{Winter Banana.}

Winter Banana-The Winter Banana originated on the farm of David Flory, near Adamsboro, Cass county, Indiana, about 1876. It was introduced by Groming Brothers, Monroe, Mich., in 1890. It has as yet been but little planted in this state.

\section{Gravenstein.}

Gravenstein-The following excellent account of the history of this variety was given by Invey in 1851: "The origin of the Gravenstein remains in some doubt. It is said to have been originally found 
in the Duke of Augustinberg's garden at Gravenstein, in Holstein, and that the original tree was grown there in the middle of the last century. Another statement is that it derived its name from being found in the garden of the castle of Crafonstein in Schleswig, and Diol says it was supposed by some to have been introduced from Italy. Be this as it may, it is a common apple throughout Germany and Sweden and was received from thence into English collections. It is undoubtedly of similar origin with the Red Astrachan and Duchess of Oldienburg, possessing the peculiar habit of growth, form of foliage and texture of fruit which distinguish the German apples.

"At what time it was first introduced into our gardens we are not aware, but as neither Coxe nor Thacher describes or names it, we suppose it was some time subsequent to the account given of it in the transactions of the London Horticultural Society in 1822. It is at the present time considerably cultivates though not to the extent its merits deserve."

In 1857 Captain De Wolfe stated that the Gravenstein was imported by him from Denmark in May, 1826. In a letter dated October 11. 1829, published in the "New England Farmer," Judge Buel, of Albany, called attention to the importation of the Gravenstein and other German apple trees which he had presented to the members of the Massachusetts Horticultural Society. Hovey states that in view of this it appears that the Gravenstein was imported to the vicinity of Albany probably prior to 1826. After these early importations Gravenstein gradually found its way into cultivation in various portions of the country. For many years it has been pretty generally disseminated through New York State, but in most localities it is grown to a limited extent only.

\section{Delicious.}

Stark Delicious-Delicions was originated at Peru, Madison county, Iowa (near Des MLoines), by the late Jesse Hiatt, and on his farm the original tree still flourishes, bearing anmual crops of as beautiful fruit of this variety as we have ever seen.

In 1895 the Stark Bros. undertook the propagation and introduction of the Delicious, purchasing outright from VIr. Hiatt the sole right to it.

The original tree of Delicious is now about fifteen years old and is thirteen inches in diameter at the ground. It makes a strong, vigorous growth, similar to the Winesap, except that the branches are stronger and need little or no pruning. Both tree and fruit are perfect models. The tree is strong and has finely molded limbs, which are adapted to bearing great weight of fruit. It does not sprout or sucker, does not succumb to blight, and has never shown signs of tenderness. 


\section{Building an Apple Tree}

A. I. Mason, of Hood River.

WANT to state to you with all sincerity that there is no part of orchard work as interesting as pruning. If I were to put a man thrcugh a test to ascertain whether or not he would become a successful orchardist. I would take him into an orehard and try to interest him for one hour in pruning. If I could not do that, I would tell him to sell out and let some one else have the job. If he could not become interested in forming a nice symmetrical round tree which can bear and retain fruit, I do not know another part of orchard work that would interest him. It is the most interesting part of the work to me. It was stated by one of the previous lecturers here that the subject of pruning is the most difficult of the whole proposition, or rather the one upon which there was a greater difference of opinion. This is true. If I do not put things here tonight as you have heard them before, you will simply have to do like the rest of us did wheri we started in the business-use your own judgment. I know that I do not agree with all of the growers, and I do not believe any two persons ean be found who do.

When starting to build an apple tree properly, it should be built like a house. Before one begins to build a house he studies what style of structure he wants, and he can almost see just how it is going to look when it is built. In building an apple tree, the same rule should be followed. Determine what style of tree you want, start out with that end in view, and follow it to perfection. That is the only way an apple tree can be successfully built. Before starting to build, one should be careful in selecting his material, the same as in building a house. This part of the work was thoroughly gone over by Mr. Newell.

I have two kinds of two-year-old trees with me this evening; one has side limbs, the other none.

Mr. Mason used lantern slides to illustrate his lecture. Exhibiting the first slide, he said:

"This represents the laying of the foundation of a tree; the beginning of it. The corner stone is being laid, so to speak. The hole has been dug. In one of the talks here something was said about a man at Hood River who digs holes 30 inches deep. If that is so, I have never heard of him, but we do dig holes 30 inches across and 


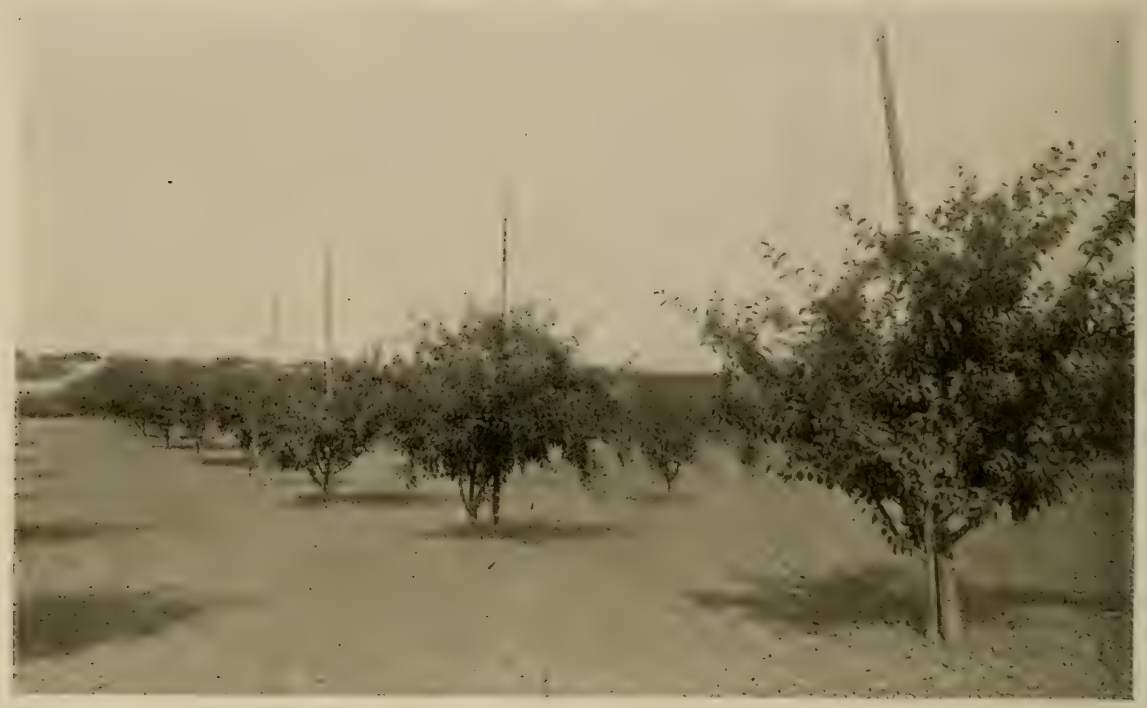

An apple orchard near The Dalles, Oregon. Note the poles from which ropes or wires are strung to support the limbs. This method of support was originated in this section.

20 inches deep, so as to have plenty of surface soil. This little board across the hole is a tree setter. The sticks were put there when the hole was dug and then this board put back and the tree set in the same notch. Consequently, when the orchard is laid out, the hole dug and the tree set, the tree will be where the stick was. It was said in one lecture that we plant our trees eight or ten inches deeper. This is a mistake. I believe I have been the cause of alvocating the planting of trees deeper than sone others. That eight or ten inches means from the top of the ground-eight or ten inches deep, not deeper. About 18 or 20 inches above the surface of the soil is the right place for a tree to be cut after being planted.

Slide No. 2 represents the second year's growth. The tree was grown one season and is now ready to enter the next season. This tree when originally set was a one-year-old tree with limbs on it. Abont the middle of July I cut the limbs off here, then the following spring, or in the latter part of the winter the inside of the tree was cut out. One of the lecturers here stated that a young tree should not be pruned in the middle of the summer. Pruning an old tree in summer produces fruit spurs, but young trees should be allowed to grow as much as they will in summer. No doubt before that tree was primed in the spring there were many limbs on the inside, but there are now four limbs which mean so much ahead. One need not think he is going to get apples by pruning of that kind. I should have 


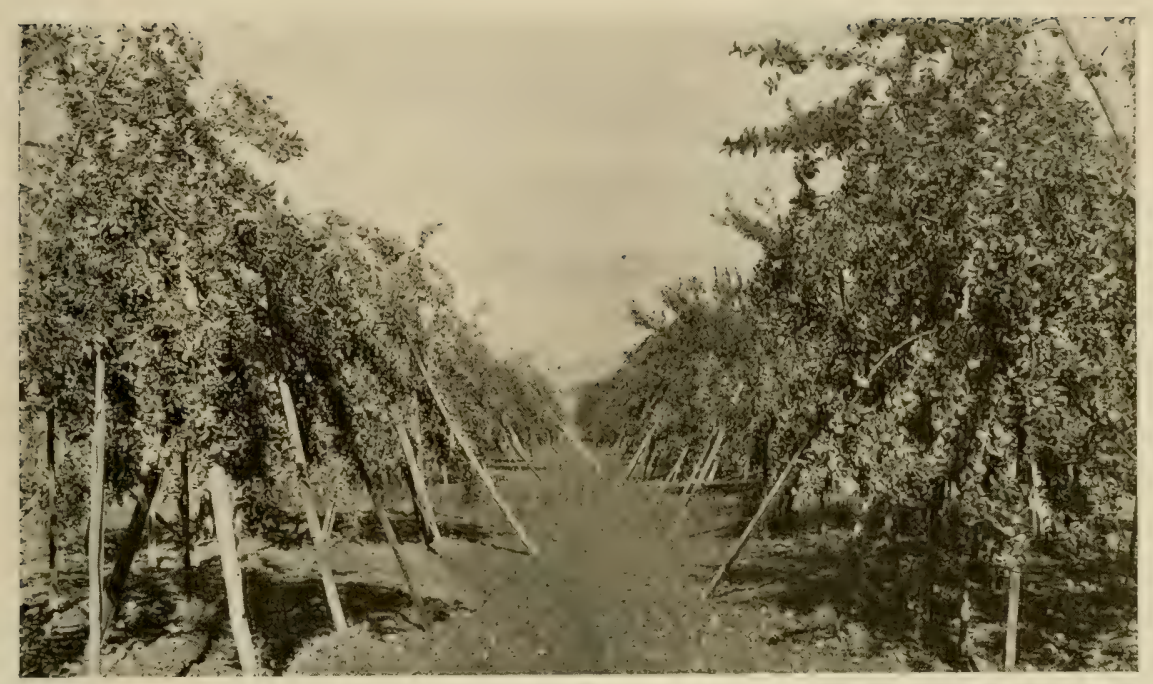

One of the famous apple orchards of the Rogue River Valley, near Medford.

suggested that on straight switch growth as soon as the growth starts out along the limbs, rub these off, leaving four or five at the top. Later on they become the center or whirl for the top. I would prefer three or four for the main upriglit stalk, but one can not always get them as he wants them, consequently he should let four of them start from the most symmetrical points around the body of the tree.

Slide No. 3 represents a tree one year older. Of course that has been doubly pruned in summer and winter, although I always prune my young trees twice a year, which is perhaps not in accordance with other advocates, but we differ in opinion. I presume some of you think that is an older tree, but by counting the growth you will finc it is pruned the same way. You will notice that I always have an open center to a tree. In other words, I leave the limbs all pointing outward toward the light. By all means, permit the center stalks which are to become rour framework to grow ahead of all side limbs.

After that I do not eut the ends of the limbs. You will notice (Slide No. 4) I have cut the laterals, but I cut them to laterals, leaving them to start out. It is simply a repetition of keeping out the inside. This shows the fifth year of a tree. The entire growth is very stalky.

Slide No. 5 represents the sixth. year. No more cutting back of the top of the tree is necessary, with the exception of long willowy growth tree. This is a Newtown. I cut my Spitzenberg trees back further whenever needed in the summer time. Some advocate the middle of August. One time I pruned three trees to test summer 
pruning. I selected three-year-old trees, all about the same size and as equal in condition as possible. I pruned one the fifteenth of June; one the fifteenth of July, and one the fifteenth of Angust. I marked the trees with a linife on the side of the trunk, so no one could steal the mark away. The tree pruned on the fifteenth of June had almost a thicket of brush all over it and inside, and anywhere from three to four-growth terminal limbs. Remember, I pruned all three trees alike. The tree pruned the fifteenth of July did not have more than onethird of the inside growth that the tree pruned June fifteenth had, and the limbs that started out on the terminals that I cut off were about one-half in number. The fifteenth of August pruning did not have inside growth,except now and then a little short sprout, perhaps three or four inches long, and the terminals only started from three to five inches and never matured. The winter was very mild. Had it been a hard winter, perhaps all that latter growth would have been lost.

I have explained to you how to form or build a young apple treea tree that has not borne any fruit, but a tree with an open center that often times requires support. (Exhibits slide No. 6). I am amazed when I read an article from some professor or orchardist almost calling a man an ignoramus because he advocates an open-center tree, saying that it will not hold fruit, that it will split down with the frost and sleet, and using almost every argument that can be thought of. I am frank to admit that if a tree is not given some kind of a mechanical construction it will not be as strong as a center-top tree would be, but I propose to show you wherein we can add the genius of man to wature and make a far better tree than nature made for itself.

Slide No. 7 represents a cross section of a tree about five or six years of age. These little black spots at "A" represent the main upright stalk. Of course I have left off all the limbs. The lines indicated by "B" are two-ply hemp manila twine. Around each stalk is tied a twine string. By taking twice as much twine to circle them it is not as difficult as to put it around twice. You will notice that with these strings holding the limbs on all sides, it would be impossible for a heavy wind to blow the tree into any kind of shape. The moment the pressure of the wind left, it would go back to its natural position. The reason I prefer to go around in one loose lap, placing one end of the string here and there, is because I do not gird the body of the tree and prevent the flow of sap. This is put on the tree at the age of five or six years for the purpose of holding it in an upright position until something better can be placed upon it. The twine used in the former illustration will last at least three years under 
our climatic conditions When the tree is eight or nine years old, the strings have rotted and are no longer strong enough to hold these uprights with safety. for they are bearing fruit and under a heavy wind they are liable to be broken down. I put in my mechanical construction for a lifetime. " $\mathrm{A}$ " represents the upright stalk of the tree. " $\mathrm{B}$ " represents a galvanized wire. This is a harness ring galvanized. At "A" this wire is fastened to the limb with a small screw eye about an inch in length. When they are all fastened to a center point of the tree, it is almost like an umbrella, absolutely impossible to break a tree at the crotch, to ever split it down with fruit, sleet or snow, or by anyone climbing it.

The object of getting the system of supports as high from the ground as possible is to have a foundation, a point of contact. from which one can begin to tie up limbs. The higher up the support, the better and stronger it will be, easier to put on the string, and easier to make the side limb support. The boy standing under the tree in this picture is about 5 feet 10 inches high. The limbs are about three feet above his head. It is only a matter of time when I will have to put another system of supports still higher, and I believe that will be the last. That part is experimental with me. It costs about 20 cents per tree to put in the wire support. The string support costs about 5 cents. No orchardist can haul props out into his orchard and haul them back to his barn. A prop cannot be put in an orchard for less than three cents. One cannot go to the woods and cut them as we used to. They must be sawed at the mill, and then it costs about half a cent to put them up, and half a cent to put them back into the barn or throw them up along the fence row. In four or five years they are rotted out and, if you want to put in a cover crop, you have an army of props under your trees all in the way, and it takes from 15 to 20 props for each tree. I have seen orchardists in our valley with that many under their trees. From an economic standpoint this system is far ahead of any I have ever seen.

\section{Questions and Answers.}

Q. How far apart do you plant?

A. Twenty-five feet. I would never plant them that close again, but would plant 30 to 32 feet apart.

Q. What system do you use in planting?

A. I have always advocated the hexagonal system, and I believe yet that it is the best, but there is one strong argument in favor of the central system, and only one. You must determine whether you have the grit to go through with the proposition and at the age of 15 
or 20 dig out every other tree. There is not one man out of 10,000 who will take out a nice tree when it is 15 years old, so I say plant in hexagons.

Q. How deep do you plant?

A. From six to eight inches. Some stock grows deeper than others. Generally you have a small tree now and then planted from two to four inches deep. When that root has grown eight inches in diameter it is out of the ground and lying on top because it is growing upward.

Q. Do you put your graft of the tree above or below the planting board?

A. Pay no attention to it. I want the roots on the under side.

$\mathrm{Q}$. What would happen if they were planted 12 inches deep?

A. Nature orercomes all difficulties. If it could get a lot of side roots started from the top it would soon start out another root system near the top. I do not think the roots of a young tree would amount to much that deep, and I do not think it would grow strong and thrive if planted 12 to 16 inches.

Q. What time do you plant?

A. That depends upon where you are planting. If your soil is light loam and in a good condition, I would plant any time of the year after the tree is dormant in the winter; if the soil is heavy, wait until spring until your soil is dry. One party told you to make a muck to dip your trees in. Do nothing of the kind. Put your tree in a barrel of water. The water makes the roots fresh, and it is far better than muck, to put roots in. If you make muck to put roots in rou will have a hard crust formed around the roots in a short time.

Q. Is it possible to prune an open-headed tree so it will retain its fruit without artificial support?

A. It is not, in my opinion. An open-headed tree would not be safe without artificial supports. As has been stated many times, the orchardist has to study his conditions under which he is working; climate, soil, etc., must all be solved. You have a different problem to solve; you have a stronger soil in the Willamette Valley. A tree will grow more rapidly, and you people down here prune too much at one time. As I told some of the people in Washington, they had stopped dehorning cattle and went to dehorning apple trees, and they have eut them all back. You cannot get any fruit buds in that way. In some of the orchards they just cut the tree to death. tree?

Q. Are there any prominent orchardists using the center-top

A. I do not know what you mean by "center-top tree." The most of them in our valley cut out the main limb. It is not as popu- 


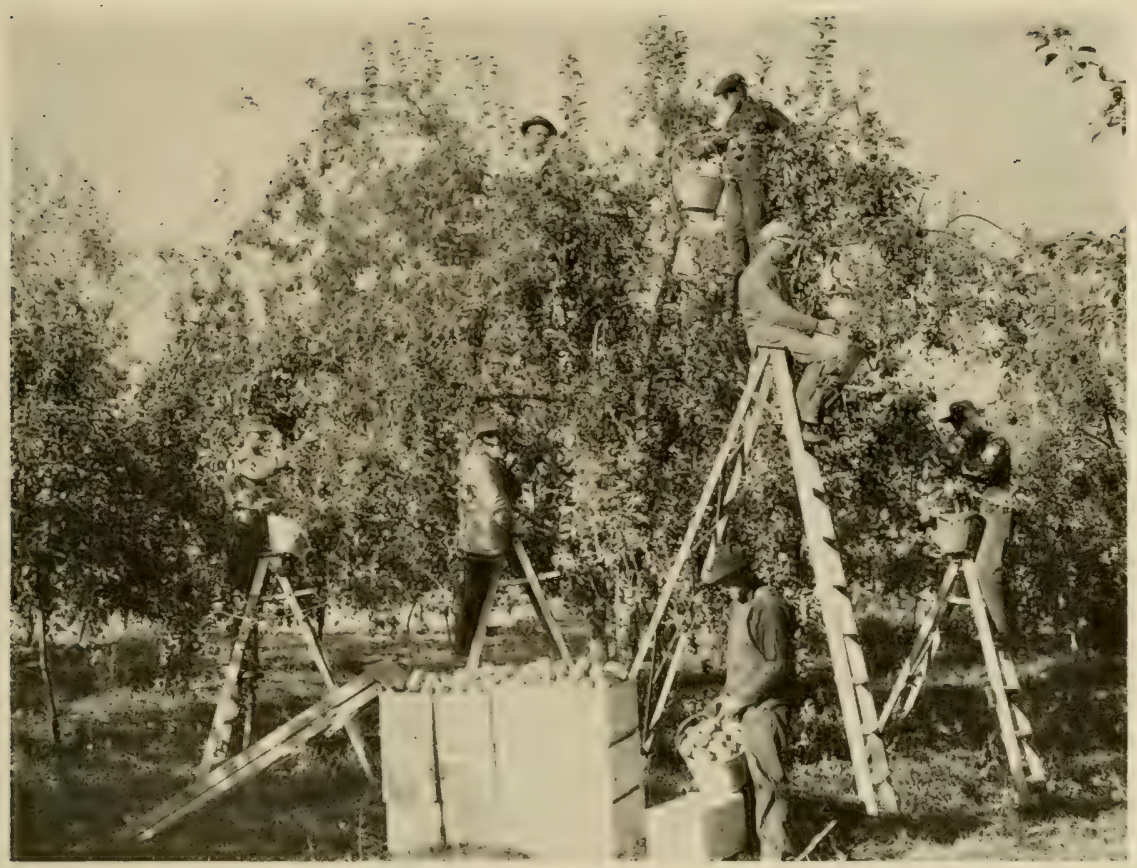

Picking apples in the Hood River Valley.

lar as it was ten years ago. An open-headed tree and an open-center tree are two different things. I want the whole inside of the tree out so you can stand in there and work, so that I can get that tripod platform in there. I do not want any center stalks in there.

Q. Do not the screw eyes injure the wood of the tree?

A. They do not. The only objection that I ever heard offered to this wire system was that those wounds might create a spot in which the fire blight might enter the tree, or the pear blight. as it is sometimes called. I have never had any trouble. I have not a single wound in my orchard caused from serew eyes. After about three rears those screw eyes are embedded under the bark. I have 5 ; spitzenbergs that would have been rotted long ago. When they were six years of age we had a very heavy snow which came about midnight, and it thawed off the next day about noon. It came the 11th day of November. The leaves had not dropped and the snow hanging on those leaves simply weighted the tree down and they split all to pieces. That is why I adopted this system and they lay flat on the ground. With the help of a neighbor we drew these trees up and tied, bolted and nailed them. In one tree today there are five bolts and fourteen nails, and it is as perfect a tree as you ever saw. I have 69 of those trees and they 
were in as bad condition as you ever saw, and you cannot see a scar on them. If the iron were injurious I surely would have found it out by this time.

Q. What prices were realized for the first-class apples at Hood River this year?

A. $\$ 2.10$ for Spitzenbergs and $\$ 2$ for Newtowns, and I do not know what Ortleys did sell for. I believe something like $\$ 1.75$ to $\$ 2$.

Q. Which brings the most money?

A. Newtowns. The Spitzenberg is my favorite to eat, but I grow them for the other fellow.

Q. In what part of the Hood River Valley do you live?

A. About the middle. Six hundred feet elevation.

Q. What is the name of your orchard?

A. That is an embarrassing question. "Liberty Home." Never had any liberty until I got there, either. That is no joshing. I worked on a salary for 40 years and had to keep my mouth shut and say nothing on public questions.

Q. Is there any advantage in white-washing the bodies of trees?

A. Yes. First it prevents the tree from absorbing the sun's rays and heating up the body of the tree. Second, you mix that with some kind of disinfectant or germ destroyer, such as concentrated lye, and it cleanses the tree; lastly, it beautifies your orchard.

Q. Do you do that every year?

A. I try to. It is not an expensive job if you know how to do it. Use your steam sprayer. I started in with a brush until the bodies of the trees got so large it took too long, so I rigged up the steam sprayer and went over the whole orchard in about half a day.

Q. What strength do you make it?

A. Just a thin paste, adding concentrated lye to it. That is as good a cleanser as I know of. I also add salt to make it stick to the tree.

Q. Would: it hurt to paint the body of the tree?

A. Under no condition would I allow a man to put paint on a tree of mine. I prefer grafting wax. It is as cheap as paint and easier to put on, and no comparison in results. I have trees that have been grafted with wax five years ago. The limbs were from three to four inches in diameter and when the wax was scraped off they were ahout as bright as when they were cut. You cannct paint a limb and leave it for 18 months without having a check down through it from three to eighteen inches deep, and down at the bottom you will find a little fungus growth, especially on end cuts. I keep a 10-pound lard bucket of wax on hand all the time.

Q. What is the cause of black heart in trees? 
A. I do not know. There are many things that might cause the center of a tree to rot. It might start from the wound of a limb that is broken or sawed off, or from a freeze. I would say cut out such a spot and fill it with grafting wax.

Q. How many times do you cultivate?

A. The cultivation depends upon what you start it with. As a rule I dise my orchard three times and then I spring-tooth harrow. One should have clean cultivation. Keep your cultivator going. Do not think about irrigation if you want to raise apples in the Willamette Valley. You had better put some kind of a sereen over the trees about the time the apples begin to ripen to keep the rain off.

Q. Do you irrigate?

A. No. I never had a drop of irrigation on my orchard.

Q. How often do you sow a cover crop?

A. I have had it in my orchard for three years. If next year is a light crop, I am going to sow it again next season. You can grow three times the amount of a cover crop here in the Willamette Valley that we can, as you have a moister soil.

Q. What time do you sow it?

A. The first of September, so as to get the benefit of the first moisture.

Q. What kind of a fertilizer do you use to bring the trees to early maturity?

A. I should want some kind of a machine to extract all the fertilizer out of the soil. That is after you get your first bearing tree. You do not need any fertilizer after the orchard has borne several crops of fruit. The kind of fertilizer is another of our future problems to solve, and we are trying to head it off with vetch.

Q. What do you use to stimulate the growth of the tree?

A. Any kind of a fertilizer will do. The best that I can give is ordinary barnyard manure. There are a dozen kinds of commercial fertilizers. Several big companies are carrying on results in our valley now.

Q. Do you believe in putting fertilizer in with the roots in planting?

A. No, I do not. I do not think it necessary unless the soil is very poor, then you show poor judgment in planting it.

Q. Do you summer prune your old orchard?

A. Now I am going to be like the preacher. I am going to tell you what to do, whether I do it or not. I do not cut back except on Spitzenbergs. Newtowns do not need it. You should take ont all this inside growth. It shades your tree, prevents circulation of air through the tree and destroys the coloring of the fruit. 


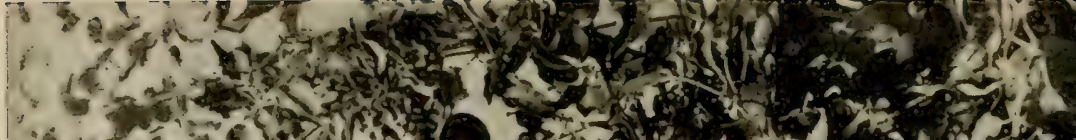

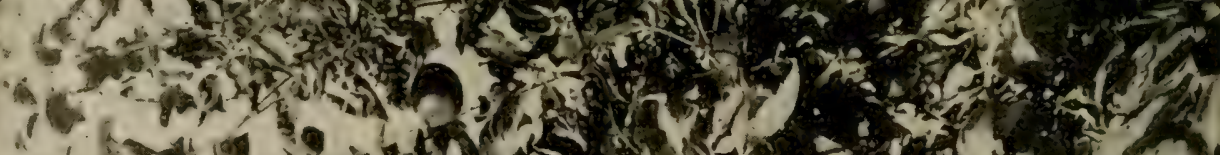

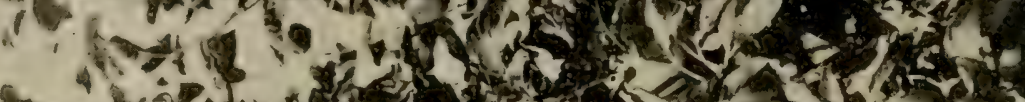

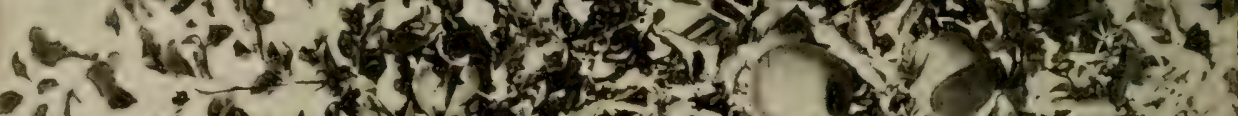

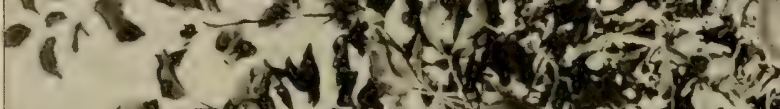

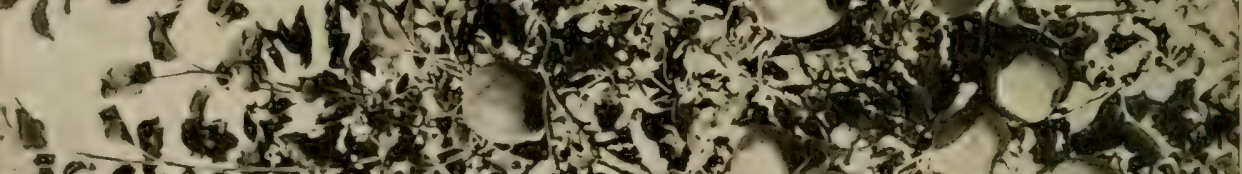
:

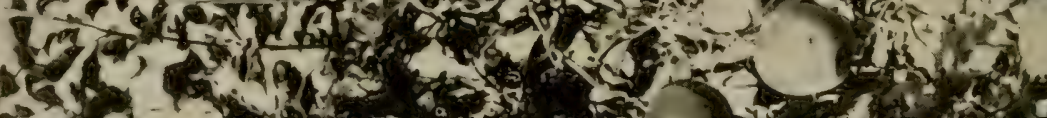



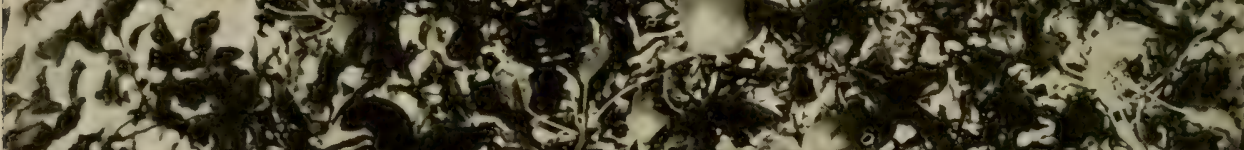

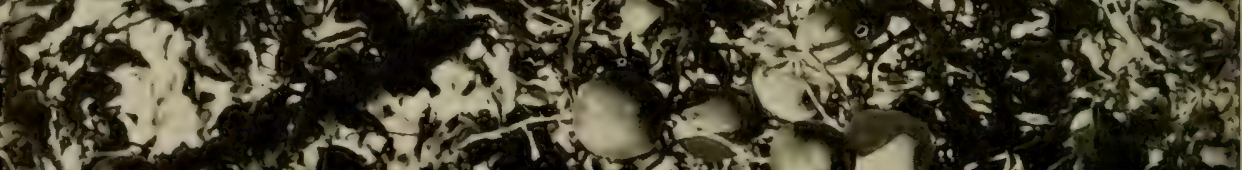

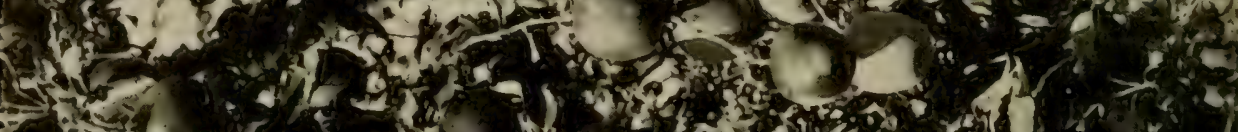

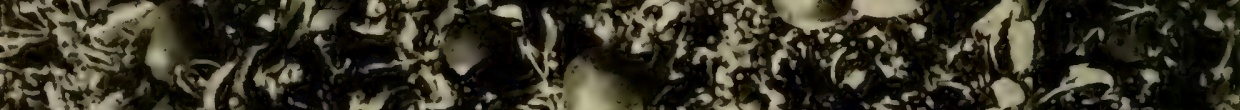

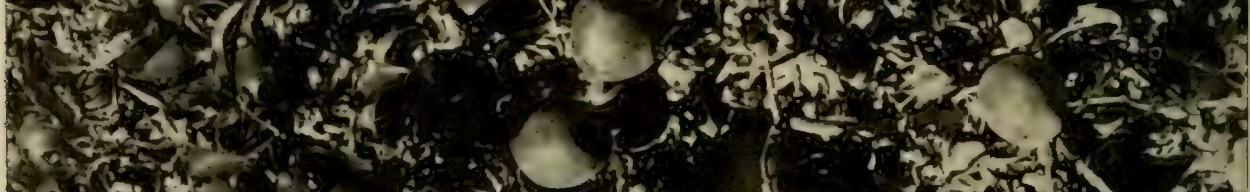

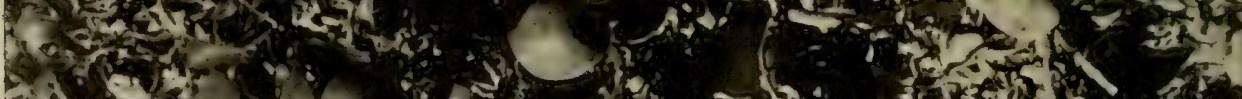

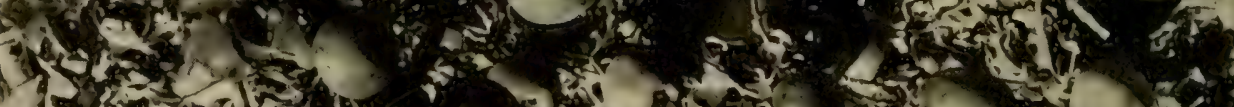

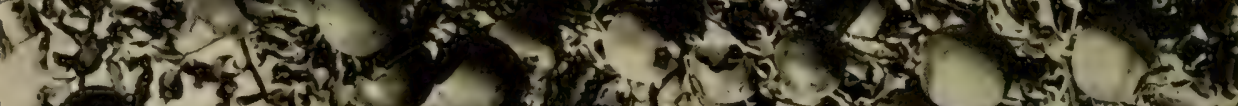

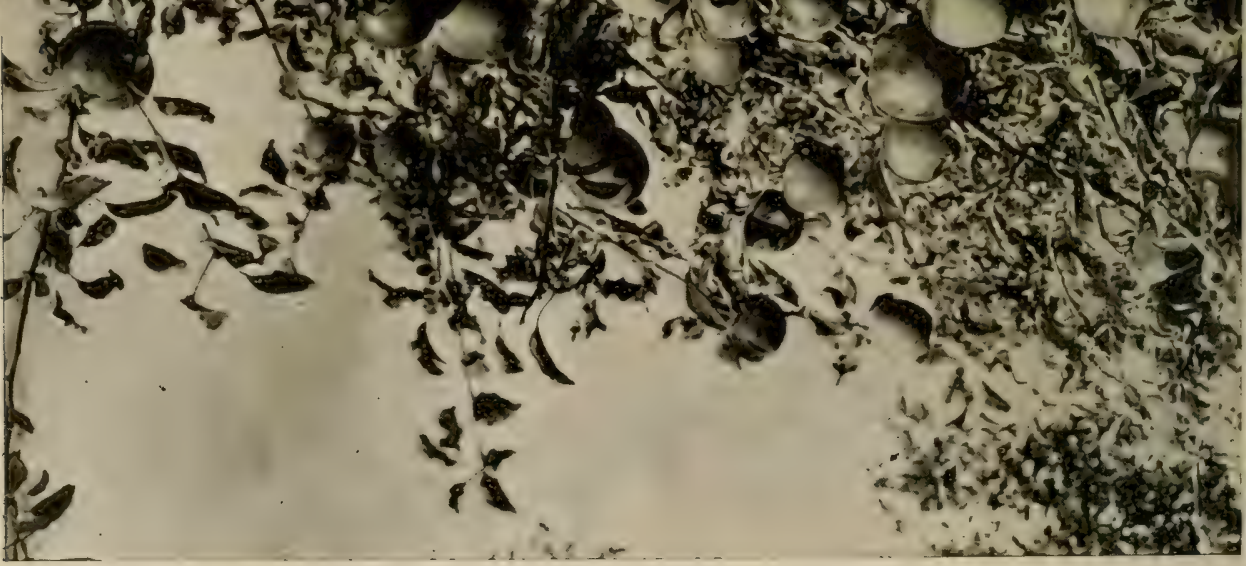


Q. How do you do grafting?

A. With a knife, pair of shears, wax and a cloth. I cannot illustrate that very well unless I have some tools.

Q. What time of year do you graft?

A. In the spring, about blossoming time.

Q. Where do you get your sprouts?

A. The previous year I get them off the larger trees. Cut it now, put it in the cellar and in the spring take and cut that up into a scion. Use two buds. Cut a pointed: wedge and put it on the outside.

Q. What is the limit of the size of stub capable of grafting?

A. I cut limbs off up to five inches through.

Q. Could it be done eight inches through?

A. I believe I would allow a water sprout to grow and graft a bud on the water sprout.

Q. Do you advocate more than one graft in the wound?

A. Yes, but do not allow but one of these grafts to form and become an upright limb, because they form a eroteh that would never unite. Suppose I had two grafts growing out of the same stub, and they were three or four inches apart, and I let them both grow. After a while they are going to increase in cliameter and will come together, but will never unite, so there will be a erotch.

Q. Is burning $\log$ and brush piles injurious to the land?

A. No. I wish I could have all the brush piles and logs in Oregon burned in my orchard.

Q. Do you advocate planting immediately after the land is cleared?

A. I did, and have never regretted it. I will admit this, that if you cultivate your land one year, you will get a better growth by planting the second year, but you will never make up for what you lose the first year. When I bought my land it had not been surveyed for 41 years, and when we came to resurvey it the first time after the government survey, I got 29 feet of my neighbor's wheat field that had been cultivated for 11 years. The first few years these rows of trees on the old wheat field were far ahead of the others, but one cannot tell the difference now.

Q. Do you advocate a filler crop?

A. No. Between my house and town there is a beautiful illustration of a filler crop. Trees were planted 24 feet apart and a peach tree in the middle. It was a combination affair. One was to take charge of it for so many years. This man was going to get rich the first ten years. The result was that this was the first season he has had a crop of peaches, and they are 5 years old. He had a few year before last, and last year the frost killed them. This year there was a 
heavy (rop and they lay on the ground and rotted. You people would not have given 35 cents a box for them. This man and his employer had a row and every one of these peach trees are out now. The peach trees got the strength that the apple trees needed now that they are ready to bear. It is an expensive proposition to pay 2 cents for a peach tree, plant it, cultivate it for five rears and then get one crop not worth 35 cents a box.

Q. How do grapes grow in the Hood River Valley?

A. They do not grow well. The nights are too cold and they will not ripen.

Q. What do you think of strawberries between the apple trees?

A. Just the same as I think of any kind of a filler. I would never have them in my orchard. Strawherries require water to make money out of them. One must irrigate and that almost drowns the trees.

Q. How about clover?

A. You cannot grow clover and eultivate. That is an impossibility. You people here perhaps can, but we cannot.

Q. How would tin cans buried under the trees affect them?

A. I do not know. I know of someone who is getting all the irom sereenings and hurying them under his Spitzenbergs to find out what effect they will have on color. I will let you know in ten years.

Q. At what elevation do they plant Spitzenbergs in IIood River?

A. Do not be misled by altitude. Sometimes it means something and sometimes it does not. My orchard is 600 feet above sea level, and in Missouri and Kansas orehards are from 2,000 to 3,000 feet in elevation. An orchard would freeze in Inod River at that elevation. You want to figure on the proximity to the snow line. The climate $60 \mathrm{or}^{2} 75$ miles east of. The Dalles is very different from ours. We are right up against Mount Hood and Mount Adams.

Q. How about the Delicious?

A. That is a nice eating apple and has as good a flavor as I ever tasted, but I would not plant it eommercially in our valley. It is hard to get color on and is ngly shaped, which makes it hard to pack.

Q. Why do you not plant Spitzenbergs, when they bring the highest price?

A. The price which you pay for a box of apples is not always the most money to the grower.

Q. Do you use pollenizers for Spitzenbergs?

A. I do not know anything about pollenization, and I never found anyone who did, not even our college men. I believe the crosspollenization of the fruit family should be the same as in the animal 
kingdom, but I do not know what varieties crossed with others will produce best results.

Q. Do you believe with the present rate of planting there will be an over-production in a few years?

A. Yes and no. Yes, if we are all a set of fools and are going to fight each other on the market and not use business judgment.

Q. Do you think it honest to buy land for $\$ 16$ per acre and sell it for $\$ 265$ ?

A. I have a piece of land that cost $\$ 9.25$ per acre and I would not take $\$ 2,500$ per acre. Would I be honest? I know of a man who bought two acres for which he paid $\$ 500$ per acre and it is just as nature put it there. It has never been touched by mortal man. That $\$ 500$ is community-made value. If you want to turn this into a single tax proposition I could talk all night. I can talk "single tax" better than apples. 


\title{
Development of Apple Trees
}

\author{
W. S. Thornber, of the Washington State College.
}

D

RUNING is done for various reasons. There are different ideas upon this subject. One of my college friends has thirteen reasons for pruning, and I want to give you two or three tonight.

First of all a tree should be pruned because it develops many more buds and branches than it can possibly produce. Nature is wasteful. A tree may develop anywhere from 120 to 200 buds the first year of its life, and the next year only three or four will develop any limbs, so nature must be taken in hand, as one might say, and helped control these tendencies. Secondly, to secure the shape and size of tree that is wanted.

There are three distinct seasons of the year when pruning can be done to advantage in our state. Your state is so much like ours that I think one can follow in the same line. The first pruning is done in the early spring, before the buds leaf out. The pruning done at this season of the year always has a tendency toward the production of wood. That is a good thing in young trees, and in ones which one wishes to rejuvenate. The second, or early summer pruning may be done in June. The third period of pruning is in the late summer.

As an experiment we had started several hundred young transplanted apple trees about five years old. We started on June 10, and pruned a portion of them very severely. On June 20 we pruned the next lot, and on June 30 we pruned another lot, and so on during the entire summer. The trees pruned on June 10 made the greatest wood growth I ever saw. The limbs were three feet in length, and I could see the scale of growth rumning up to August 30, when the growth in this case was only about four inches. The trees pruned Angust 10th ceased growth entirely, and I secured buds about an inch in length. That is where I got my first fruit. If your orehard is a cultivated one it must be pruned later. If an orchard in which one grows hay and raises calves, goats and cows, one must prune earlier.

Now comes the formation of a tree. There are three types of trees: High-headed trees, low-headed trees, and bush trees. These three types are found all over the Pacific Northwest. The low-headed type is the one I am going to urge very strongly tonight-a tree that is from 12 to 20 inches-very near the ground. There is danger in heading the 
bush tree too low. Branches coming absolutely from the ground do not form as perfect a mion with the trunk as they should, and in a short time they will start to pull apart.

The next subject is the shaping of a tree, the head, and a good solid short trunk. First of all is the pyramid head. Our Canadian and English friends are very partial to this system. The pyramids are exposed to a small amount of light, which gives a poor quality of fruit, and in times of storm they break down quite readily.

The second type of tree is the open base, which is just the reverse of the pyramid and might be called a vase-clear open in the center. That is the best tree. Just a few words about the frame work. The branches must be on all sides of the tree and a long distance apart. If bunched together they produce weak branches, and one side of the tree will become lopped. The limbs should be well spread apart to give them strength. I do not want anything in my orehard but a firstclass tree, from three to four feet in height, with a good sturdy system and a heavy stem, with buds all the way down. Cut a tree off 24 inches from the ground. That is the most important pruning that one will ever give his tree. Do this if you never do any more. No other pruning should be necessary for the first year.

I was traveling through the Yakima Valley some time ago, and I noted a peach orchard of nice trees. The man who was pruning them put his arms around the limbs of a tree, bringing them to a single bunch, and sliced the top off. I said to him, "What were you before you became a horticulturist?" He said, "I was a barber." Do not practice any barbarous systems on your trees.

\section{Questions and Answers.}

Q. How about walnuts?

A. I would prune the walnut trees straight up, giving a good straight shape.

Q. Do you advise mulching or digging around them?

A. I would pulverize the soil and keep it well eultivated. A good dust mulch is the best that can be provided.

Q. What is your recommendation in regard to dwarf apples for fillers?

A. In Western Washington and Oregon, where there is clay soil, I would recommend the pear as a filler.

Q. How deep do you advise planting?

A. Two inches deeper than what they were in the nursery.

Q. Is there any advantage in putting them four or six inches down? 
A. I do not think there is any.

Q. Do you recommend the square or hexagonal system?

A. That depends upon conditions. If it is to develop a big commercial orchard. I would plant the hexagonal system, but where one must grow something among the trees and have as wide a space as possible, I would recommend the square system.

Q. How is the Wagener tree for a filler?

A. It is one of our best fillers and comes into bearing early. It produces fair crops the fourth year after planting, and some the second year.

Q. Do you recommend fillers for a commercial orehard?

A. Yes, I want to get all the returns I can just as soon as I can. The only danger is that the filler will be left in the orchard too long.

Q. Would it be better to use pears?

A. Pears make a better filler.

Q. How about strawberries?

A. They are very good if not planted too closely to the trees. I do not want any permanent thing growing closer than four feet to a two-year-old apple tree, and no closer than six feet to a four-yearold apple tree.

Q. Don't you think it is best to plant trees so as to make a specialty of berries and keep that up indefinitely?

A. I have no doubt about that. There are splendid returns being made in that way, but they must be fertilized.

Q. What is the principal objection to starting only three limbs on a tree?

A. One may lose a limb and then he will have the worst lind of a tree.

Q. Have you been trying any of Burbank's productions?

A. Yes, but they do not work well with us. My last big loss was rhubarb. Prohably 2000 roots died. Some of their plants are very good, but they are not adapted to our conditions.

Q. How about irrigation?

A. That depends upon the soil. We irrigate three times a year. Other places irrigate five or six, and some 10 or 12 . Three good irrigattions should be sufticient.

Q. Do irrigated apples keep well?

A. Yes, if they are not over-irrigated.

Q. What do you think about irrigating where it is not necessary?

A. I would not irrigate in that case. It is not necessary until there is a rop on the tree. and not always then, but it is mighty goost insurance to have. I helieve in irrigating all things in an orchard. 
Q. How soon can you bring the Northern Spy into bearing by: summer pruning?

A. I have brought it into bearing in Easterm Washington in the fourth rear. I had a strong tree to start with, and the tree developed five or six limbs in. Jume the first year. I prumed that tree in . Jume as I ordinarily would the following year, and got a growth where the branches were from 18 to 24 inches in length. I made a 3 -year-old tree of it in two years.

Q. What is considered a good growth for the first year?

A. From 18 inches to three feet. If I do not get 18 inches, I think there is something wrong, either a lack of moisture. or late planting.

Q. What would you think of trees in an orchard that grow to an unequal height-some to inches and others four feet. when they have been newly planted?

A. I will answer that by asking you how you take certain trees from a bunch, some living and some dead? The answer is that trees coming from the center of the bunch have frequently dried out. and it may be the same in your planting.

Q. Do you have any white mildew, and what do you do for it?



Exhibit of Hood River Valley (Oregon) apples, showing rarious methods of packing. 
A. Yes, I think we have everything there is in the West. We use lime-sulphur spray each year.

Q. What is the per cent of new trees that die?

A. That is rather a difficult question. I should judge that we lost on an average 30 per cent last year in our State. Usually the per cent is not so much as that.

Q. What is the best time to plant?

A. Early in the spring. In Western Oregon, possibly fall planting would be better, or very early spring planting.

Q. How do you trim the roots?

A. I turn them up so I can look right at the bottom of the roots, and trim them from four to eight inches in length. Any fibrous roots I pull out, as they are usually dead.

Q. How do you plant a tree?

A. I dig a hole large enough to accommodate the roots, so it will be two inches deeper than in the nursery row. When the tree is set, I get down into the hole with both feet and tramp all the way around it. When a tree is planted in this manner it is very rarely that one is lost.

Q. Where the soil is very dry and sandy, wouldn't it be better to plant two or three inches deeper?

A. No, I would rather get it by eultivation. We have that kind of soil and are not planting any deeper. TVe use, however, a little heavier stock where the soil is liable to be blown about and the sand cuts the trees.

Q. How about Clark County?

A. It is a gravelly loam and a wash soil. Any soils of that kind, where there is not a hardpan closer than three feet, is all right for orchard work.

Q. What slope do you recommend?

A. In orchard work generally, where there is any danger of -hortage of color, I prefer a south slope. Ordinarily we get plenty of color anyway, so I pay little attention to the slope. In Eastern Washingtow, where there is danger of freezing a northern slope is preferable -north or northeast.

Q. How about subsoils?

A. I want a porous subsoil.

Q. Clark County orchardists are going out of prune-raising a good deal.

A. I notice the orchards that have been taken care of have been moneymakers right straight along in Clark County, but there are some conditions there that we have not been able to meet yet. In spite of that, they are planting more prunes now than during the last 12 or 14 years.

Q. What influence has the soil?

A. It depends upon the chemical content of the soil. A light quality soil colors apples more readily than a dark quality soil. 
Q. Does pollination affect color?

A. The effect is very slight. However, I would take advantage of it. If I had apples that were liable to rum light-colored, like some of our Spitzenbergs, I would plant some dark ones in the orchard, like Arkansas Black.

Q. What variety of apples would you suggest?

A. Baldwin, Northern Spy, the Wagener and possibly the Jonathan. These are for red apples. For yellow apples, Yellow Newtown, Grimes Golden, Ortley and Red Cheek.

Q. How do the Yellow Newtown and the Spitzenberg do in the Yakima Valley?

A. Very well. I do not think the results are as good as in the Hood River section, but our Yellow Newtowns are coming out well.

Q. Do snow mountains affect orchards?

A. Only as the cold air comes down.

Q. What do you recommend for White Salmon?

A. Spitzenberg, Yellow Newtown, Ortley, Baldwin, Wagener.

Q. How do pears do on clay soil?

A. They are right at home in clay soil. Some of the best pear land I know of in the United States is over here north.

Q. Does it make any difference in the elevation?

A. Not very much. Of course, one gets a little smaller sized apples on heavy dry soils.

Q. How about this central selling ageney?

A. I think we will have to get to that. We will have to get together on some hasis of that kind. In California they have been getting on with their orange problem in that way very nicely.

Q. Has pear blight ever done any damage here in the Northwest?

A. Yes; 14 years ago a good many pear orchards were destroyed by pear blight. I do not dread it at all. It is not a serious problem. I do not think there has ever been any pear blight between Portland and British Columbia. I have never seen any indication of it.

Q. Does it attack the young trees?

A. Yes. I have seen near Walla Walla a 2-year-old pear orchard, 90 per cent of which was killed by pear blight.

Q. What is its first appearance and how does it look?

A. The first appearance that you will see is when the trees are in bloom. The blossoms become rusty and the leaves turn black.

Q. Does it attack apples?

A. Yes. I got my first experience with pear blight with apples.

Q. How about keeping bees in an orchard?

A. Keep bees by all means to carry the pollen.

Q. Don't they die from the poison spray?

A. One can spray at such a season of the year that it will not harm them, say after the petals are off. It is with the early spraying that one catches the bees. 




Picking apples in the Walla IValla Valley. Washington. 


\section{Prun ing}

IIon. WV. K. Newell. President of the Oregon State Board of IIorticlture.

○

plunge into my subject at once, that of pruning, I think it is best to say first that it is perhaps one of the most difficult subjects to present clearly before an audience without a tree or two to illustrate with. If I could take you into an orchard, I could illustrate very much better the plan or practice of pruning than I can possibly do here this evening.

I think there is not a single branch of the subject of horticulture in which there is such a wide diversity of opinion among horticulturists ns in the practice of pruning. It is harder to lay down any definite I'nles in regard to pruning than in regard to almost any of the other related branches. We all agree very closely how trees should be planted, cultivated and sprayed. but when it comes to the matter of pruning the tree, it is much more a matter of opinion. Hence the beginner has the greatest difficulty in getting proper advice. I have brought some trees here so I could do a little bit of illustrating.

First a few words about selecting a nursery tree before we come to pruning. These trees represent the different grades. They are all rootbudded trees. I wish to impress upon you first the advantage of getting a budded tree instead of what is frequently sold, a piece-root grafted tree. These budded trees usually come from France as 1-yearold seedlings. A great many of the French peasant farmers make a business of growing them. The seeds are gathered throughout the country. They grow them one year and then dig them up in November or December and ship them to the United States. mostly to our nurseries as apple seedlings, where they are planted out in February, Mareh or April and grown until August when they begin budding them 12, 18 and 20 inches. They cut a bud from the bearing tree that they wish to propagate, make a slit in the bark of the seedlings and insert that bud under the bark and tie it there, and the bud immediately joins with the tree. It remains dormant until the following spring. Then the seedling is cut just above the bud, which grows and makes the tree. Here is a tree one year old from the bud, but it is practically three years old. You know the difference between that and the piece-root grafter tree is that when that seedling comes from the nurseryman he will take and prune it, leaving about four or five inches of the root on the tor and plant that to bud from. This will be pruned and watered 
thronghout the season, thus foreing the root which will sell the same ynar, and to all appearances it is just as good a tree as the budded orie, but ? cu can readily see that it is impossible for that tree to have tha same root system as this which has been growing two years longer.

There is a distinction again between grafted trees as they are fre. quently grown and between these piece-root grafts. If that bu? fails to grow in August, the nurseryman will go in February or March and ent that seedling off next to the ground and insert a graft here on the seedling root, which. will come on and make a tree by fall that will practically be as good as the budded tree, because it has the same root system. A tree that has been budded on a 3-year-old root is worth double or treble the piece-root grafted tree, and that is a point one should always look for in purchasing trees. There is another point. The nurseryman grades his trees. First grades are four to six feet high, and what is known as No. 2 grade runs three to five feet in height, and No. 3 are trees under three feet in height. The great tendency among purchasers is to fasten upon the biggest tree that it is possible to get. They want a four to six-foot tree rather than a smaller one, but height alone should not be the guide in selecting the tree. It is fully as important-I should say more important - that the tree should show good caliber here than that it should show height alone. We should pay more attention to that. Many times you can get the trees for much less money of this size than you can for the larger.

Now, as regards pruning: If this tree conld be taken up from the mursery with all the dirt left on it, of comse it could be transferred without much of the root pruning, but if this tree is dug in November, as is usual, and carried over the winter to January, February or March before it is planted, it is inevitable that these smaller roots would become dry and dead, so when this tree is planted all these small roots should be pruned off. The reason is that those roots are so dry that the tips will die anyway and the tree would make a start quicker if the roots are cut off than if they were left to encumber its growth. The top should be pruned vigorously and the roots should be left from four to six inches long, and headed back by making a cut on the under side of the root and sloping in that manner so that when the tree is planted this ent surface will point down to the bottom of the hole that will tend to form a callous where it is cut and throw ont the first feeding roots, so that the cut does not have a chance to dry. This will then force itself down and anchor the tree good and solicl, but if all these slender roots were left every one of them would be turuing up, and the tendency of the roots would be to grow to the top of the soil. A tree pruned in that shape is rery easily planted and has all the root system that is necessary to thoroughly anchor the tree in the ground. It 
should then be set down to about two inches below where the bud was inserted as it stands in the mursery-just barely above the gromuland that puts the roots down far enough so that when the dirt is properly tramped around it (tramp it good and solid with both feet) it is going to start growth at once. This pruning should not be done until you are ready to plant. If it is a sunshiny or windy day, it is a good plan to puddle the tree. This cau be done by dipping the tree into a barrel of liquid mud. Place the barrel on a sled, and as soon as the tree is dipped, take it out and put it into the hole at once.

If you allow the surface to dry it will harden over and not start to grow for a long time. In this climate it is always preferable to plant trees in the fall if possible. There is another point that you must remember. If trees are to be planted in the fall, do not get trees that are too green. If you are in a hurry and insist upon the nurseryman taking out these trees and shipping them before they are ready, he must strip the leaves off and dig them prematurely, before they have perfectly ripened. Trees are sure to suffer from that practice. If not able to plant trees in the fall, it is a good practice to buy them in the fall and have them shipped to your place and heel them in. The trees will winter very much better in an orchard heeled in than they will in the nurseryman's packing shed. When purchasing trees use good business sense as you do in buying other things. Do not wait for an agent to come around and coax you into buying a tree. No nurseryman likes to do this, but they have been almost forced to because people will not buy otherwise. Make it a practice to go to the uurseryman direct and, if possible, go to his nursery and make vour selections.

If trees are planted in the fall head them back about 18 or 20 inches from the ground the latter part of February. Cut about half an inch above the bud. That allows bud room enough there so it will heal over nicely without dying back or allowing any dead wood. That is the way a tree wants to be pruned the first year. Always plant one-year-old trees; not two. (Exhibits tree.) One can prune and spread just as one wants to. It has been headed in the nursery row about a foot higher than it onght to be in the orchard. That is another practice which demand forces the nurseryman to follow. Nearly everyone who goes to buy a tree wants it like this, and the nurseryman naturally has it up here to make a good big tree-the kind you want. Otherwise this tree has grown very nicely. At the end of the first season this has made a very good branch. You will notice that these limbs are very well scattered all over the trunk of the tree and do not all come out just at one point. When this is headed back in this manner every bud practically all over the tree from the ground up will grow in the spring. In fact, they seem to grow two or three 
inches longer than one wants them. Rub off the lower ones, leaving from six to eight of the top buds (certainly not less than five). Do not leave just the four or five top ones nor rub all in one place. This is practically all a tree should have in the way of pruning the first summer. Some people make a practice of pruning in August if the trees are making too much growth. That may be all right in windy locations where the wind whips the twigs over to one side in order to make them stiff enough to stand up against the wind, but that only happens in a few localities. Let the tree grow as tall as it will the first year.

What we want to do is to frame up the skeleton of a tree in such a manner that it will begin to throw out and form width, yet grow up instead of growing out and falling down to the ground so that one cannot get near it to cultivate. Bring it out and tone it up so that it makes a vase shape, keeping the body of the tree close to the ground, heading it up sufficiently so that an extension harrow with three or four horses abreast can be worked throughout the orehard and clear under the tree. When three limbs grow out close together they will not be properly distributed, so the first thing is to take a limb right out. It should be pointed up so that it will get plenty of sunshine inside and still allow most of the limbs to remain. There is another point that must be borne in mind; that is the kind of tree to be prumed. Some trees, like the Northern Spy, tend to grow straight up and make twice the growth in height as they do in width. Other trees, like Jonathans, for instance, tend to grow out and fall down. When pruning a Northern Spy tree, prune invariaby to an outside bud the first two or three years so the tree will spread out. On a Jonathan tree these limbs have a downward tendeney and should be pruned to an inside bud in order to keep it from spreading out and lopping over too far. The Newtown Pippin has not a very pronounced tendency either way. It grows quite nicely and should be pruned something like this: (Exhibits tree.) Begin with this bud, throwing it in that direetion, and this twig here. This tree should be down 18 inches from the ground with this top. That would bring these limbs within 10 or 12 inches of the ground. This should be done in February. Pruning of young trees should never be done until the freezing weather is past. After the trees get older they can be pruned any time with safety. If one prunes a tree at this time of the year these end buds might kill back. Of comrse, every hud on these limbs will start as soon as the limbs start, and they want to be rubbed off within 12 inches of the ground. Along in .June if they get too thick, prune out a portion of the inside buds that are starting. I would not practice any heading back this second summer except in a very windy location. Every tree 
should be induced to grow fast and strong for wood growth, and this is accomplished by pruning in the winter time. The general practice of pruming in the winter for wood growth and in the summer for fruit growth holds good.

At the end of the second year and at the beginning of the third head these limbs again, which should then be from two to four feet long, and the same general principle should be involved, heading these back one-half to two-thirds of their growth, thus making the limbs strong and stocky so that they will not break down under the load of fruit. Never let two limbs start at the same point making a "Y," because invariably they will split down. At the beginning of the third season, starting in June, thin those limbs out again, and then again about the middle of August. If the tree is making good, rapid growth, head back that season's growth anywhere from one-fourth to onethird of its growth. This will tend to check the limbs. There is no reason why a tree should grow six or seven years without bearing. It should begin to bear by the fourth or fifth year, and it is simply a (;)estion of proper pruning to bring them into bearing. The Northern Spy takes from 10 to 12 years, but it can be forced into bearing in four years by proper pruning. The third summer is the time to begin the cncouragement of the formation of fruit buds. The time of year to do this depends upon elimatic conditions. As a general rule it can be done the first three weeks in August; sometimes a little later, perhaps. The wood growth is largely over by the first of August, and the tree then begins to spread out and increase in caliber rather than in height. That will tend to force out these bud into fruit buds and the tree should bear a few apples the next season.

Practice thinning in the winter time and head back in the summer. A tree can be kept bearing practically regular crops. Of course, it is impossible to keep any tree bearing a full crop regularly, but wonders can be done by this system of pruning.

A bud, if allowed to grow all summer, naturally goes into the end buds, and the fruit buds do not have an equal chance. The other one has to be eut off in order to force the sap back. It naturally goes to the end of the limb. The fruit buds cannot get any sap until after the end of the limb has gotten all it wants.

(Exhibits limb with half-grown apples.) 'This is a very interesting sample of what can be accomplished by summer pruming. This limb came from the orchard of Mr. J. E. Stanbury, inspector of horticulture for MIultnomah county. It was headed back the 9th day of August, just as I have been trying to illustrate to you, by cutting back a year's growth and trying to foree the formation of frut buds. These 


\section{7)



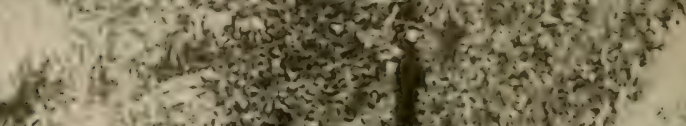

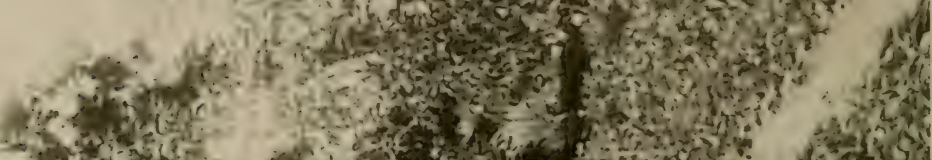

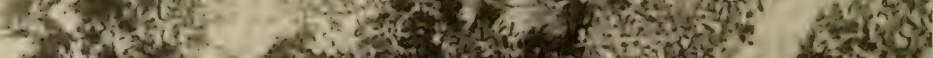

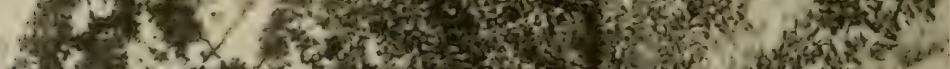

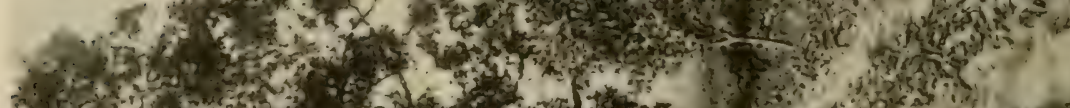

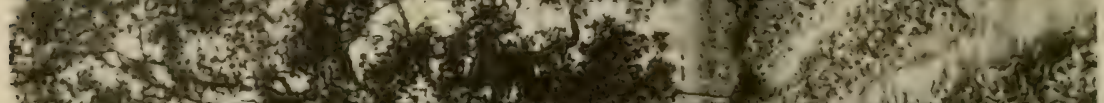

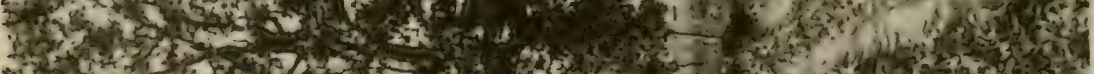

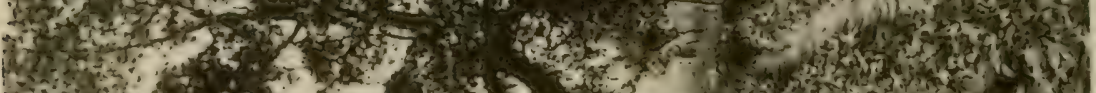
Fir.

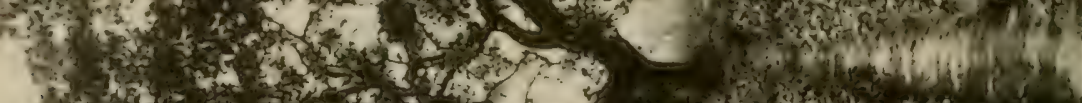

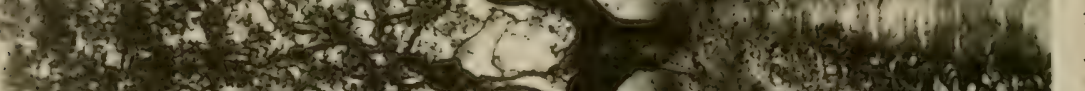

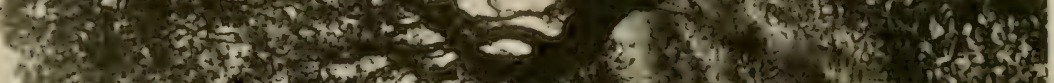

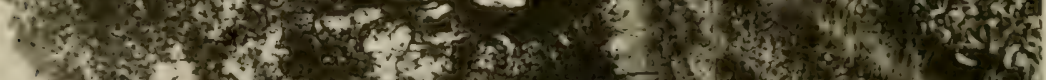

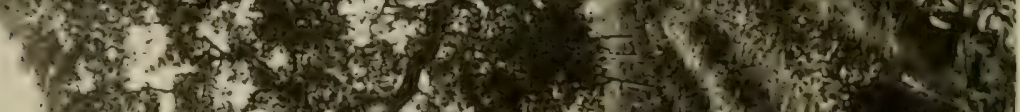

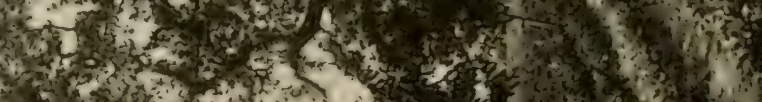

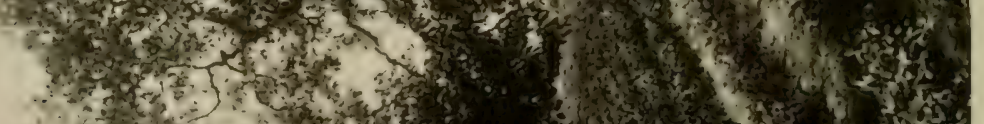

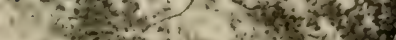

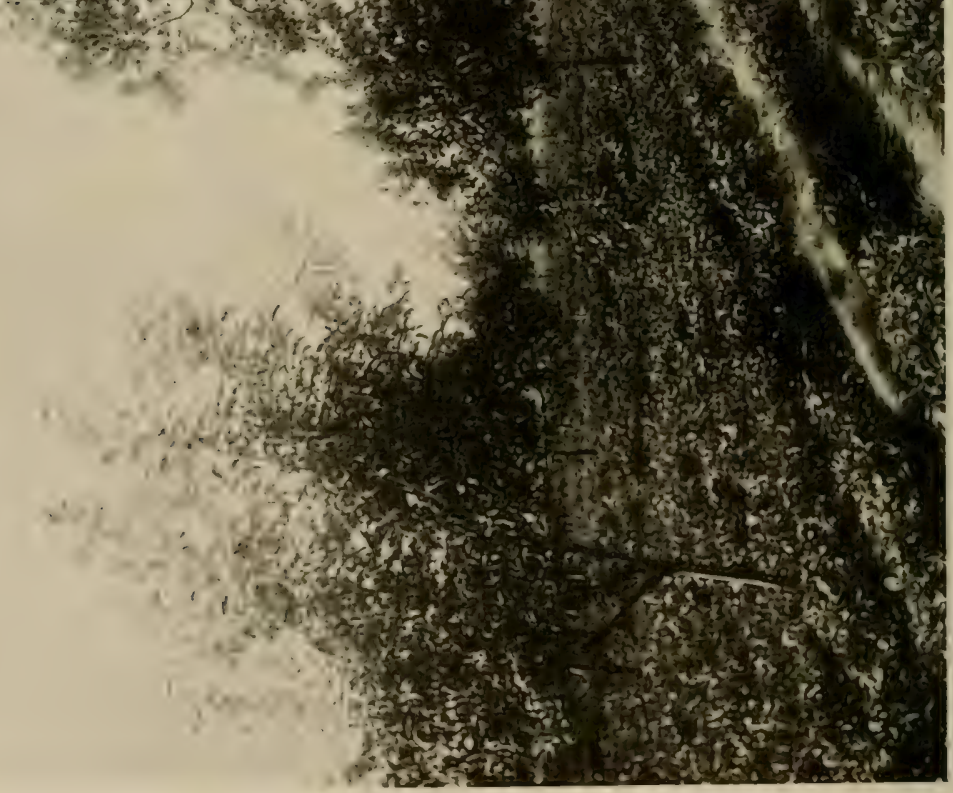

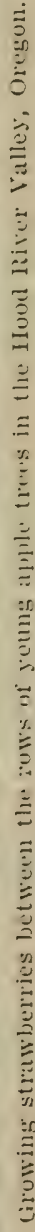


fruit buds, which naturally would have been very small, have been forced out here this fall and have blossomed and borne that much of a crop of fruit. You need not be alarmed about doing this. This is largely due to the climatic conditions this year, and the excessive amount of sumshine. Mr. Stanbury is located on the Columbia Slough where the trees grow very vigorously all summer on account of excessive moisture.

The further point that is necessary to make the tree bear as much as possible is the thinning of the fruit. A single bud naturally cannot produce two crops in succession. One bud produces this crop, and that is the end of that particular fruit bud, but where this fruit is borne this year it will start to grow right beside that fruit bud. If that grows as it does on some trees, particularly like the Spitzenberg, eight, ten or twelve inches long during the summer, that should be prumed also in the middle of August, that is, after the tree is in full bearing. That will tend the rest of the season to develop other fruit spurs down along this spur the following season. That is rather a difficult point to make clear, but the general practice is, as I said before, head back, cutting off the ends in the summer, and the thinning out of what we call suckers in the winter. It will tend to develop a lot of undesirable suckers. The limbs that are going to be taken out should be taken out in the winter, but after the tree is in bearing you can do that most any time. Thinning out should be done in the winter and the topping off of the summer's growth should he done in the summer. The tree should have a system of good, strong limbs that are strong enough to carry themselves and all the fruit that they should bear without bending down, and these main limbs should be filled with fruit buds clear back down to the trunk of the tree, instead of allowing these limbs to grow up 10 and 20 feet and allowing the fruit to form on the end of the tree. The only way to keep them back is to follow a regular system of summer pruning. An apple that is formed along these limbs on a short fruit spur is in much better shape to be grown than if it is way out on the end of a limh. That is even more particularly true of the peach tree than of the apple. At the end of six or seven years the peach tree has got nothing to prune, whereas, if the orchardist had pruned that tree back as it should have been, very small, keeping the fruit buds down next to the trunk, it would have lived and borne just as long as the average apple tree.

\section{Questions and Answers.}

Q. How can one tell the difference between a piece grafted tree and one that is grafted at the root? 
A. That is something one will have to notice very carefully. In. sist upon the nurseryman telling you.

Q. What does the term "heeled in" mean?

A. That means covering the trees up to protect them during the winter; dig a trench about a foot deep on the best high, dry ground in the orchard, and set the trees in as they come in bundles from the nursery. Cut the bundles and spread them a little, then throw a thin layer of dirt over the roots with considerable force and pack it down well to fill up all the space between the trees so that the water will run off. If it is very cold weather, start covering them with straw. A tree carried over in that shape is in much better shape for planting.

Q. How can one distinguish the fruit spurs from sprouts?

A. The fruit bud is always larger and of lighter color. That will blossom and bear fruit. stock?

Q. Should one try to prune a leader up from the first year's

A. No, not exactly, yet one must be left a little bit longer than the other in order to make sure that the tree will not split open and break down. I do not believe in cutting the inside of the tree out.

Q. Would it be wise to prune a little high, say 30 inches?

A. No, do not start the tree 30 inches from the ground, because this would simply move the limbs up higher. The tree should grow low enough so that one can do most of his thinning and picking from the ground.

Q. Is it better to get trees from a nearby nursery than from a distance?

A. Nearly always. If you can get good trees at home do not go away, and furthermore, you have the advantage of seeing them. It is a difficult matter to ship trees a couple of hundred miles or across the continent without doing them injury.

Q. Should one prune for fall planting?

A. Yes, practically the same. If a tree has just been freshly dug out of the ground, the fine roots need not be pruned quite so much. The very fine feeding roots are nearly always broken off.

Q. In case trees are left over how far apart should they be planted?

A. I would not plant them at all. A tree that has been left out of the ground during the season, then replanted in the nursery, and then replanted again is not going to be of much value.

Q. What time in August should a tree be trimmed?

A. About the middle.

Q. Is there not a tendency for the new shoots to freeze this winter? 
A. Yes, but that would not be of any particular consequence.

Q. How many limbs should be left?

A. All that the tree will carry.

Q. You spoke of something like eight limbs?

A. I mean leave eight buds so there will be that many to select from.

Q. Is it not a fact that the limbs get farther apart as the tree gets older?

A. They grow out, also increasing the diameter, so they are probably about the same relative position as before.

Q. Some orchardists in Hood River plant eight and ten inches deeper than others. What do you think of that?

A. That depends upon climate and soil. Their soil is drier and reguires deeper planting than in the Willamette Valley.

Q. One man up there is digging holes 30 inches deep.

A. If he puts the trees down 30 inches he is going decidedly to the rstreme. About two inches deeper than the tree stood in the nursery row is about right.

Q. Is it necessary to paint small wounds?

A. No, not at all. Any cut less than an inch will heal over if cut properly.

Q. What instrument should be used?

A. I use a sharp knife on these small roots. It makes a cleaner cut. For larger pruning I would suggest a pair of two-handed shears; a pair that will make a sliding eut, but is hinged so that the knives slide together. These are very handy for cutting large limbs.

Q. Can trees that have been neglected for two or three years be made successful?

A. Yes, but in that case more vigorous pruning would have to be done in the winter than otherwise. Pruning wants to be done regularly twice a year. Do not wait longer and then do it all at once. Prune in February, then go through your orchard and head the trees back. trees?

Q. Is there any atvantage in whitewashing the trunks of young

A. No, unless there is a very hot sun. Sometimes they may be shaded with the whitewash. By adding a little arsenate of lead to the whitewash the apple tree borer may be prevented. This worm girdles the tree in summer.

Q. What are water sprouts?

A. A growth that is forced out of the old wood where there is no visible bud.

Q. Is it not possible to make a bearing limb out of a water sprout? 
A. Yes, if it is given time enough. If a limb is broken off a water sprout can be forced out and frequently there will be a new top on the tree.

Q. Is an irrigated tree as good as one raised without irrigation?

A. Yes, if it is not over-irrigated, but the tendency is to give it too much water.

Q. How can one get up to a tree that grows so low to the ground?

A. The tree should be grown up without spreading out or sloping to the ground.

Q. In forcing the tree to-bearing, does it not affect its life?

A. Not necessarily, if properly taken care of. There is no reason why one should wait six or seven years for a tree to bear. A Northern Spy frequently will not bear for 14 years, but there is no reason why it should not the sixth or seventh year. The Jonathan will bear a few apples in three years.

(2. Should the Spitzenberg be headed up more than the Newtown?

A. Yes. 


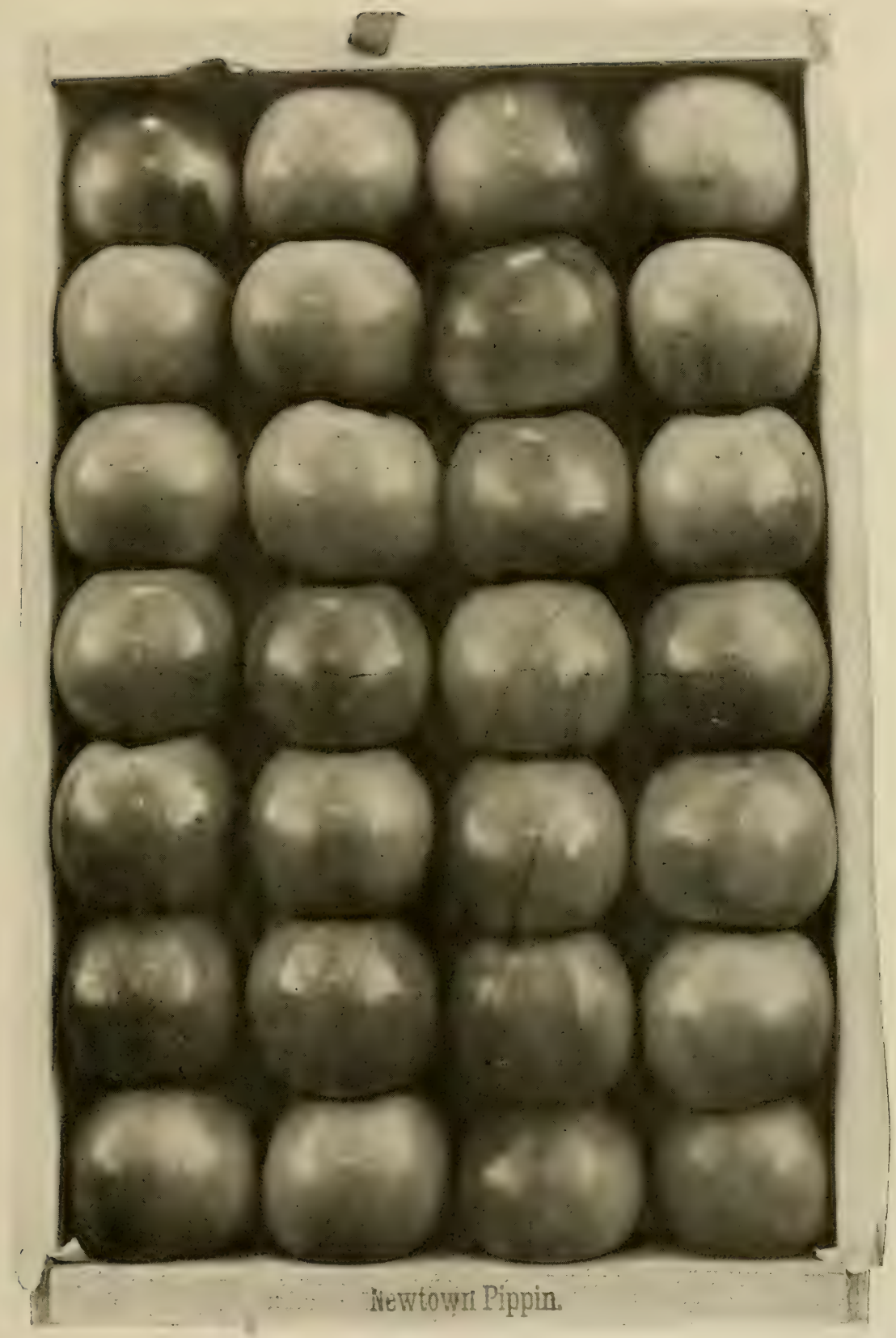

A good example of careful apple packing which has done much to advertise the fruit of the Pacific Northwest. 


\section{Pollen izing}

Professor E. J. Krause, of the Oregon Agricultural College.

I AMI sure that the question of pollination of our orehard fruits will be of immense interest to you, both from the practical standpoint and from the standpoint of the experimental work which is heing earried on at Corvallis. Every orchardist, or every man who expects to become one, should know exactly what he is going to do ahout the matter of pollination. The reason why he should is this: Some varieties are known as the self-sterile and others as self-fertilized.

Before I come to that I desire to take up some other reasons why firuit trees do not set fruit other than through pollination. We would like to solve, if possible, the whole reason of pollination. If that were possible, we would easily remedy it. That is why so many questions arise from so many places throughout the states. "What is the matter with my trees? The fruit is all falling off." Go and investigate, and nine times out of ten it can be told very quickly what the matter is.

One of the points, then, which I wish to make other than a matter of pollination in this: $A$ great deal of trouble is caused by freezing during the winter. There is a severe freeze and one may think that the trees are not injured, but if wo cut open the buds we will think otherwise; the flower buds will lardly ever stand late freezing. The posterior of the stamen of the flower is injured in that case. There will be a great many blossoms on your trees, but no fruit. Somehow it cannot set fruit. Another point that I might mention is this. Naturally some varieties will shed their fruit. It is not a matter of pollination in that case. The Spitzenberg is one such variety. I suppose many of you know that the Spitzenberg will thin itself down to one or two in a cluster? The Comice pear will do the same, that is, thin itself down to one pear. Many who have orchards of Comice pears do not think it necessary to go over their trees to thin them down, and frequently if two do stick they will mature all right, but frequently also the fruit will drop from the eluster. That is to say, you have eight or ten fruit sprigs on a fruit branch. Usually it will thin itself down to what you wish.

Another point in that line is the care of your orchard. If your orchard is in very poor fertility-very poor cultivation-your fruit 
will have a tendency to fall. Pollination will have nothing to do with it in that case. The same is true if your orchard is in intense cultivation. That is to say, if your trees are growing too fast-are forming too much wood growth. I am sure you have all noticed young trees laden down with bloom set no fruit; instead of maturing fruit, it drops all its blossoms, and you have nothing but the wood growth. As the tree grows older the wood becomes less.

Another point is when your tree is disease infected. If your tree has anthracnose, or any of the other diseases, there will be a tendency toward falling off of bloom. Naturally, a tree in an unhealthy condition will not set as much fruit as otherwise. Pollination has nothing to do in that case.

Now I will come to pollination proper. By the term of selfsterile is meant when a variety is planted in large blocks by themselves they are incapable of setting fruit. By self-fertile we mean capable of setting fruit without the intervention of any other variety. Probably some of you would like to know what we mean by pollination. We mean simply the transfer of the pollen, or the male element, to the stamen, or the female element of the plant. That is true pollination. You can pollinate until your hair is gray; if your pollination does not oceur, you will not have any fruit set.

Some of the agencies which affect pollination are these: First of all, insects. This is the primary factor in all of our orehard fruits. Then the other factor is the wind. Certain trees, such as the walnut, depend almost entirely on wind for pollination. All those trees that have a very light, dusty pollen depend on the wind. All trees which have sticky pollen depend on insects, such as the apple, pear, peach and plum trees.

In order to be sure of pollination, I would advise keeping some bees in the orchard. If your neighbor does it for you, so much the better. As probably some of you know, bees do not generally work closely at home, so they will be apt to work in your trees as well as your neighbor's. You must depend upon insects. Pear blight is carried by insects. The sweet, honey-like liquid, which is simply alive with the bacteria of pear blight, is sought by insects, and right there they spread the disease. The disease runs down the blossom into the branch; down the branch into the trunk, and the tree is gone. It sounds quite simple, but when ycu lose an orehard tree it is a serious matter. You have to depend on domestic hees. You cannot depend on the wild bees. An orchard that is kept in a good state of cultivation should be supplied with a hive of bees.

When we come to consider that we need a pollenizer, the point is 
what it shall be. Many think it is a good thing to have one variety of trees and that they get betier fruil. The question is, should I plant a mixed variety? By no means. It is not necessary. If you have two varieties, one being pollinated by the other, that is what we are working for, to find varieties that have a mutual affinity, as we call it. That is to say, we have Newtowns and Spitzenbergs. The Newtown will pollenize the Spitzenberg.

Before I go any further I had probably better take up some of the effects of pollination. The first one of them is this: If a variety is self-sterile, it hecomes fertile, that is to say, it will set fruit with the other pollenates. and the next point is that it is stated in some cases the fruit of the cross pollinated apples is larger. Another point is this: It is stated that it affects the color of one variety. For the last two years I have seen no evidence whatever that would support that statement. It is stated on good anthority that such does oceur. Some of the Western anthorities state that if a spitzenberg is pollinated hy the Newtown it will be of a poor color. I cannot support that statement. The Spitzenherg colors just as well with the Newtowns as it: does with the Arkansas Blacks. The Newtown and the Spitzenberg are the same color.

In size there is no increase or decrease. I think there has been too little done on this in an experimental way-mostly chance observation. When you get a man who is an observer, rather than an experimenter. he will attribute it to some cause which has absolutely nothing to do with it, but if a man is an experimenter, he will try to discover the ause. Of the commercial varieties grown in Oregon, as far as I know. for the last two years, we have had no evidence to support such a statement that the color of the variety is affected or has been affected in any way-absolutely none.

Another statement is that an effect of pollination is that one gets more seeds in the apple. Of course, that has nothing to do with it. It is only of interest in an experimental way. There is this to be taken into consideration: Usually the greater number of seeds the fruit contains, the larger will be the fruit. That is a point worthy of note. The statement is also made that size decreases by pollination. In the case of Bose pears when the Bosc was pollinated with Bartlett they were big pears; when pollinated with Comice they were of medium size, and with Winter Nellis, they were of small size. On the other hamd, when Comice was pollinated with Winter Nellis it gave us the largest pears, so we have got to determine for every variety what pollination will do. You cannot predict what is going to happen. You have got to experiment-not one year, but two or three, and the result that you 
may attain one year may be contradicted the next. You cannot say, "Well, that is going to come aut so and so." It does not work that way.

We have found that certain of our varieties are better adapted for good pollenizers. First of all we should be sure that the varieties will blossom at the same time, because if one blossoms one week and the other comes into bloom the next, there is no chance for cross pollination. The next point is that they should both be commercial varieties. No use planting those that are of no commercial value. The next point is that they shall be of mutual affinity; that the one shall be able to fertilize the other-for instance, the Spitzenberg and Newtown should be reciprocal. The next point is this-that they should come into bloom about the same day. As you know, some varieties come into bloom much earlier than others. That can be obviated. For instance, a dwarf will come into bearing in about four years and will blossom in the third year. As you all know, dwarf trees are being used for fillers, so you can use dwarf trees which come into full bloom in three years, and in that way not lose your crop, and when you have no further use for them for that purpose, take them out.

Some have recommended that you plant about 10 rows of one and then 10 of the other. That is a little too far apart. I believe I would

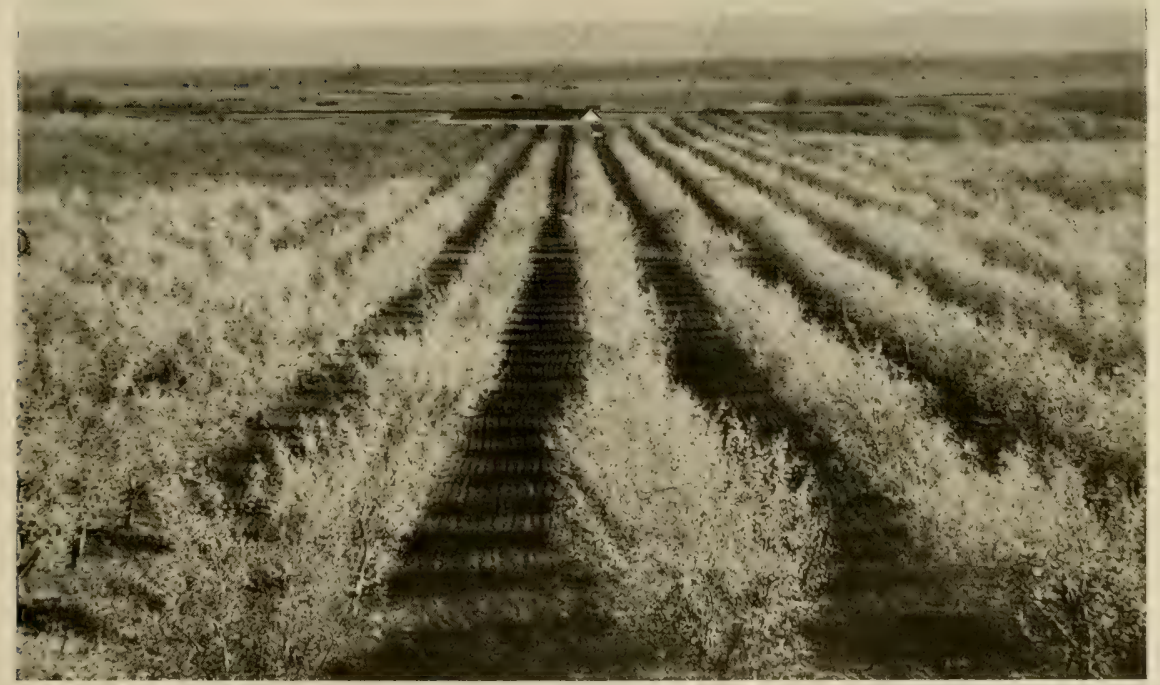

An apple orchard in full bloom-Yakima Valley, Washington. 
prefer to plant four of one and four of the other. You see that makes it quite convenient in harvesting. I would recommend four rows of Newtowns and then four rows of Spitzenbergs, then four rows of Newlowns and four rows of Spitzenbergs, for they will cross any tro rows and that is all the rlistance they have to go. If you were to use ten and one, as is sometimes recommended, the one row has too much to do for the rows on each side. If the row you are using as pollenizer is deficient in pollen, it will hardly do. That is certainly all wrong and the bees cannot do their work. They would have a great deal further to go with five rows on one side and five on the other. You would not be as likely to get as good results as if planted two rows apart as described. Then there is the matter of harvesting. You have four rows here and four rows there, so it makes it well worth while to consider. You can well afford to go down through your orchard covering four rows and both being of a commereial variety will make harvesting easier. I have in mind one of the very finest pear orchards in the State, and probably the United States, which is set that way. First it has four rows of Bartletts, then four rows of Anjous, and so on. Then comes the Winter Nellis and the Comice in the same way. They found it very convenient in harvesting; no more trouble than if they had all been of one kind. In case you have an old orehard I would recommend that instead of going through and grafting a little dab here and there, you go over a whole row of trees at a time.

As a pollenizer the Winter Pearmain is par excellence. At the present time that variety is not used or is not grown much. I understand, however, that that variety is going to be grown much more than it is at this time. For two years it has given us the best of results by far of any we have ever used.

For the pears-For the Bose I will recommend Comice; for the Comice, Winter Nellis, and for the Bartlett, Anjou. Winter Nellis and the Comice work magnificently together. We have worked for several years along this line, and we are getting results down now where there is no longer a lot of hot-air. We know that we ean recommend and recommend definitely what shall be planted of certain varieties. We have experimented for several years and will have to experiment for several more years.

This must be borne in mind: That as a variety is self-sterile in one locality it may be absolutely self-fertile in another. Some pears that are self-sterile in the East are perfectly self-fertile out here. There is no way of accounting for that. As I said before, they are affected by food supply and the state of cultivation of your orchard. In our work we are endeavoring to find out the best pollenizers for our com- 
mercial varieties that we can recommend to those that are best suited to various districts. We may find that a variety for the Willamette Valley, for instance, is not adapted to Hood River, and that a variety which is adapted to Hood River is not adapted to the Willamette Valley. All these points have to be taken into consideration.

The matter of pollination really means dollars in a man's pocket when he stops to consider it seriously. The work in the United States has been going on since 189t, and it is far from solved yet as to why a variety which is self-fertile here is not so in another loeality. This is one of the points that we are trying to find out.

There is a bulletin published by the college (No. 104), written by Professor Lewis and Mr. Vincent, on the pollination of the apple. One of the main points of value of this bulletin is that it gives you the time of bloom of the different varieties and which ean be used to pollinate. Each bulletin is printed with a plain diagram which you can fully understand.

\section{Questions and Answers.}

Q. Would you put a pollenizer in between the Spitzenberg and Newtown?

A. I see no necessity for it. The Spitzenberg and Newtowns will fertilize each other perfectly.

Q. Didn't one of your bulletins about a year ago, when they made the survey in Hood River, recommend the Arkansas Black or the Ortley?

A. Yes.

Q. Have you had cause to change your opinion since?

A. Not on that point, but it is not absolutely necessary.

Q. Would you recommend leaving out the Ortley or Arkansas Black entirely?

A. Yes, if you wish to. The Newtown and Spitzenberg will pollenize each other, or you can put the Arkansas Black and Ortley in if you want to, but there is no advantage in doing it.

Q. If you planted the Ortley or Arkansas Black, how would you plant them?

A. I would plant them in rows of four-four rows of Newtowns. four rows of Spitzenbergs, and then four rows of Arkansas Black, and four rows of Ortleys.

Q. Would you plant the Ortley a long way from the Spitzenberg?

A. Yes.

Q. "Better Fruit" about two years ago had an article advocating the pollination of Newtown and Spitzenberg. 
A. That is all right, but it was not necessary. Spy?

Q. What variety can be used in connection with the Northern

A. You can use any of the varieties I have named-Newtown, Arkansas Black, Red Cheek Pippin.

Q. What do you use with the Ortley?

A. Lse Newtowns and Spitzenbergs with the Ortley. They give very good results.

Q. What do you use with the Winter Banana?

A. Newtowns or Spitzenbergs. Either one will do.

Q. Is there much difference in the keeping quality of the Bartlett pear in different sections?

A. Yes, quite a bit.

Q. Do the Newtown and Spitzenberg fertilize each other?

A. Yes.

Q. Does that hold good in all our countries?

A. Yes, so far as we know.

Q. How does the Jonathan work in connection with the Newtown?

A. All right.

Q. How do the Jomathan and Winesap work together?

A. Pretty well, so far as the Winesap is concerned, but I am thinking the Jonathan would get the short end of it. The Jonathan sets fruit pretty well without pollenizer.

Q. Is the Ortley a heavy pollen producer?

A. The White Winter Pearmain is the greatest I know of.

Q. How is that as an apple?

A. Very good. It is a good winter apple. It is universally successful, and is perfectly self-fertile. The quality is excellent to my notion.

Q. Does the Rome Beauty pollenize with the Newtown?

A. Yes.

Q. How about Grimes Golden?

A. Newtown is the best. 


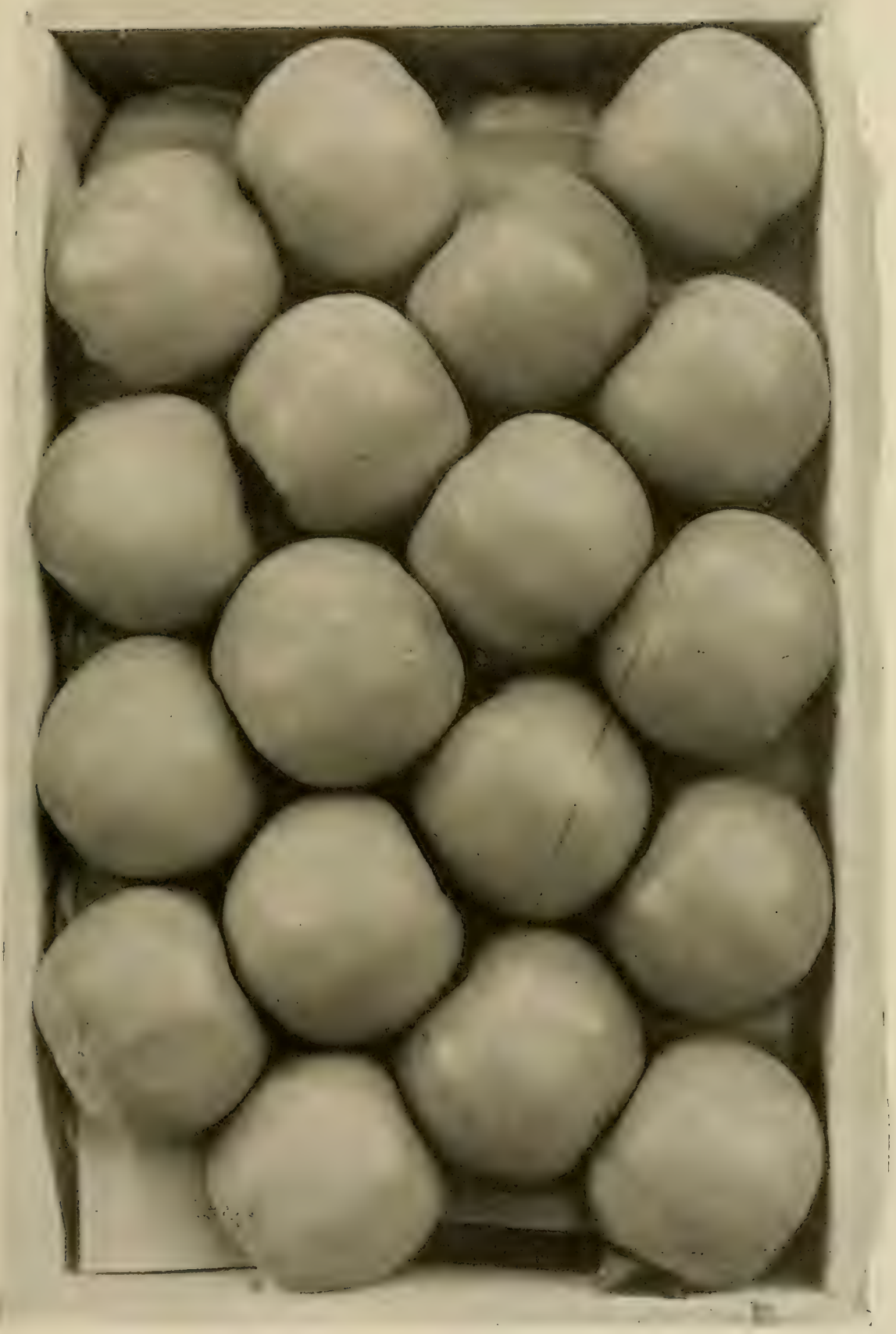

The diagonal apple pack as made in the Hood River Valley. 


\section{The Best in Apple Culture}

H. Mr. Williamson, Secretary of the Oregon State Board of Horticulture.

$\Gamma_{N}$ the past few years I have been asked many times to talk upon the subject of the probability or improbability of averproduction of apples. I have come to the conclusion that the time spent in discussing this subject is practically wasted. Unless production is limited by natural or artificial monopoly, oceasional periods of overproduction are inevitable in all industries. Overproduction is an incident of progress. It is a factor in bringing about the survival of the fittest and of raising the standard of those who remain producers by eliminating those whose methods are poorest. Those who suffer least in times of overproduction and make the largest profits at other times are those who use the best methods throughout in production and marketing. This is so plain that every one admits its truth, but a study of the results obtained in many branches of agrienlture and horticulture will convince the student that, while the truth of the statement may be generally accepted, there are few who are sufficiently convinced of its truth to show their acceptance by their deeds. Few appear to know how much difference there is between the returns obtained by those who use the best methods and those who use the poorest methods. or even those of average methods.

Neither the climatic nor the soil conditions in Maine are especially favorable for the production of a large yield of sweet corn of high quality. This fact and the resultant, and because of demand for sweet corn for camming, the farmers there have given so much attention to the Lest methods of producing it that they have raised the average yield of sweet corn in $\lambda$ Iaine far above that of the country at large, and exceed the yield obtained in the great corn State of Illinois by nearly 50 per cent. If the methods applied to the produetion of sweet corn in Illinois were equal to those used in Maine, the yield obtained in Illinois wonld much exceed the yield obtained in Maine.

The climatic conditions in Massachusetts are distinetly less favorable for the procluction of tomatoes than are those of a majority of the other States of the Union, and yet the census of 1900 showed that the average yield of tomatoes in Xassachusetts is 345 bushels per acre. while the average yield for the Lnited States as a whole is 165 bushels. This great difference in favor of Massachusetts is wholly due to the better methods of the growers of that State. 
In no other important branch of agricultural industry is there so great a difference in the results obtained by men of the best methods and those obtained hy men of the poorest methods as in the production of apples. The County of Orleans, New York, leads all other counties in the United States east of the Rocky Mountains in the volume and value of apples produced. The industry of raising apples in that county is highly prosperous. It is not probable that there is any other county of large production of apples east of the Rocky Mountains in which the methods of growers average as high as in Orleans County. The Cornell University Experiment Station a few years ago completed an investigation of the apple industry of Orleans County, covering a period of five years. For that time it was found that there were in the county 18 orchards. in no one of which the sales for the five years averaged less than $\$ 300$ per acre per year. On the other hand, there were $18 t$ orchards, from which the average annual sales fell under $\$ 100$ per acre, and 72 orchards from which the average anuual sales were less than $\$ 50$ per acre. If this investigation had covered the past: three years, the difference would have been even more pronounced, as the best orchardists have been obtaining much higher prices in the past three years than in the period covered by the investigation.

We have no available statisties of this kind for Oregon, but, if we had, it would be found that the difference in the average returns obtained by the 50 best apple growers of this State and the 500 worst would be far greater than that shown by the Orleans County investigation. The difference in the returns obtained by the most suecessful and the least suceessful growers, both in Orleans County, New York, and in Oregon is mainly due to the human factor in production. It starts with the knowledge and judgment shown in the selection of a site as being more or less adapted to apple culture in soil, aspect, proximity to shipping point, character of community, the choice of varieties to plant, the methods of preparing the land, planting and caring for the orehard, and the marketing of the fruit.

There are some varieties of apples of high quality which cannot be produced at as low cost as apples of some other variety, but it is a rule with few exceptions that the growers who obtain the largest gross returns per acre of any given variety produce marketable fruit at the lowest cost per box. When, therefore, the grower who is selling only \$.50 worth of apples per acre is producing his fruit at a loss, the man who is selling $\$ 100$ worth per acre may be making a moderate profit, and the grower who is selling $\$ 300$ worth per acre, a large profit. In the long run the man who obtains average returus of only $\$ 100$ per acre will not be able to hold out in competition with the grower who is ohtaining $\$ 300$ or more per acre for his crop of apples. Those who 
apply the best methods to every phase of the business of producing and marketing apples will, in the long run, gain rather than lose as a result of periods of over-production.

We have in Oregon unusually favorable climate conditions for apple-raising, and a great area of rich land favorably situated for apple orchards. Probably no other State is as fortunate in these particulars. These farorable natural conditions are greatly in our favor if we do not lean mpon them for success. Our apples have also acquired an msurpassed reputation in many market. 'This is also to our advantage, if we do not rely upon this reputation for success. Our natural advantages do not assure success in proflucing the best and mnst profitalle apples -they merely give us a certain percentage of advantage over competitors in achieving the feat. There is great danger of using too large a figure in estimating this pereentage. In the proportion that a grower relies for success on advantage of soil and climate, just in that proportion he decreases the probability of achieving success. Every observing fruit grower who travels abroad is convinced that one of the greatest dangers which threatens the future of Oregon's apple industry is that too many persons will engage in it who expect Nature to do more than its share. At the last meeting of the Oregon State IIorticultural Society, IIon. II. B. Miller stated certain truths on this subject in a most forcible manner. Mr. Miller has been an extensive and successful apple grower in Oregon; has been presiclent of the Oregon Agricultural College, and of the State Board of IIorticultme; Consul at different points in China; Consul-General in Japan, and Consul at Belfast, Ireland. In all of these places and on the Continent of Europe he has investigated fruits and fruit growing.

In his adcless before the State IIorticultural Society he said that from his personal observance he could say that it is possible to grow as good apples in China and Japan, and in a number of the countries of Europe as in Oregon. IIe also called attention to what Belfast. Ireland, has accomplished in certain lines of manufacturing without natural advantages. With but a limited home supply of tow and without water power or a home supply of fual, it has made itself the leading linen-manufacturing eity of the world; without natural power and without a home supply of either coal, iron or lumber. it has developed the greatest shipbuilding plant in the world; without a home supply of tobaceo it has built up the largest tobaceo-manufacturing establishment of the world.

Mr. Miller believes in Oregon as an apple-growing State. He believes that if we do our part Portland will become the greatest appleshipping point in the world. He is engaging in orchard planting on a large scale. He sees as one who studies the subject sees, that while 
we are doing much in Oregon to promote the planting of apple orehards, we are doing little to insure the practice of the best methods by those who plant or buy these orchards, and still less to provide an adequate method of marketing the fruit.

Every man and woman who engages in the apple-growing industry in Oregon must realize that the sure road to success for the apple grower is to surpass those of all competitors in every particular from the selection of the land to the final distribution of the fruit. Oregon apples now enjoy a higher reputation than those of any other State of the Union. We know this because all over the United States growers are claiming that they can raise just as good apples as Oregon if they use Oregon methods. Who has made this valuable reputation for Oregon apples? Iow many communities really deserve auy material credit for the part they have taken in achieving it? Actually two, and, to so large an extent only one, that it makes little difference where you go in Oregon you will be told that the particular district you are visiting could raise just as good apples as Ifood River. What show has climate and soil in leading the Hood River orchardists to adopt the methods without which no place can produce such perfect apples as are sent to market from that place? How much had climate and soil to do with their most effective methods of calling the attention of the public to the superiority of their fruit? What part did natural advantages play in the development of their unrivaled system of honest and skillful packing. or in the co-operation of the growers in the State? Even if we concede that the IIood River Valley has some slight climatic advantages for apple production, it was not these advantages which made it what it is in the apple-producing industry, but the superior method used by its growers. In a large measure the original credit for the high standards set up at IIood River are due to a few men and notably to one man who from the earliest settlement of the valley down to the present time has never missed an opportunity to preach the doctrine of the best.

It has been said that it is safer to shake a red rag in the face of an angry bull than to suggest to E. L. Smith the advisability of planting Ben Davis apples in the Hood River Valley. If we are to surpass all competitors in our methods of producing and marketing apples. we must not underrate our competitors, and we must know what they are doing. It will never be safe to rest upon laurels already won. The world moves and progress in science and art is more rapid than formerly, and will be more rapid in the future than it is now. There are those who are learning from us and if we keep in the lead we must be ready and eager to learn from others. It is no safer to rest upon the 
belief that we are producing the best apples grown than it is to depend upon superior climatic and soil conditions for success.

The wise man of old told an everlasting truth when he said that pride goeth before destruction, and if we boast too much of the superjority of our apples we will become self-satisfied and while indulging in this luxury some of our competitors will leave us in the rear. If we are to surpass all competitor's it is necessary that our methods not only produce the best fruit, but do this at the lowest cost at which such fruit can be produced. We must also fully understand that the production of the best fruit at the lowest practical cost will be only half the battle. The methods of caring for orchards and packing apples in our hest districts in Oregon are much further advanced than our methods of marketing apples. We have only as yet taken the first step on the ladder in our efforts to reach a solution of the marketing problem. There are about 10,000 eities and towns in the United States in which newspapers are published. In practically all of these there are merchants who do buy or who could be induced to buy apples in carload lots. It costs no more to ship a carload of apples from the station in Oregon where the apples are packed to one of the smaller of these torns than it does to ship it to one of the great jobbing centers. Our Fruit Unions, as yet, ship mainly to the larger wholesale centers. So far as the fruit is intended for consumption in those centers the present method is adequate. When, however, a carload of apples is shipped to a jobber in some of the Eastern cities, unloaded there, placed in storage, loaded in a car again and shipped to a retailer in some town or city 100 miles from that center, the cost of getting the fruit from the Eastern packer to the Eastern retailer has been doubled. At the present time it even happens frequently that the car goes from the center to a wholesale fruit dealer in some smaller city, and from that smaller city to a retailer in some other eity or town. We cannot claim that we are using the best methods of marketing our apples until we have overcome the srstem now in vogue and which, while it lasts. will continue to make good apples so costly that the masses can only afford to use them in limited quantities.

We may rest assured that the problem of overcoming this enstly system of distribution will he solved and that the State whose growers solve it most satisfactorily will gain a great advantage. We must also follow the example of manufacturers in exploiting our apples and in inducing merchants to buy them. The fact that the real secret of suceess in the apple business is found in superiority of methods from start to finish should encourage rather than disenurage any rightminded person who is thinking of engaging in the business of raising apples. Some person always does a certain thing better than any other 
person; some community does it better than any other community. 'The strife to excel in the business of growing and marketing apples is an honorable one. If carried on in a whole-hearted way it benefits all who engage in it and results in good to others. All progress in the world comes from doing a thing better than it has been done before. The ambition to surpass all that has been done before has been the moving cause of nearly all of the progress which the world has made. The joy of competitive struggle is a symptom of virility. The absence of ambition to excel means that decadence has begun. There can be no more honorable strife than one which will result in the production of the best apples at the lowest possible cost and the finding of a method of marketing the apples which will reduce to a minimum the cost of transferring those apples from the producer to the consumer. It is a strife which will result in good and the benefits will be divided between producer and consmmer. We have the advantages of favorable climate and a great area of the best of apple land which will cnable us to make Oregon the leading apple-growing State of the Union if we do our part which is to do our best to surpass all competitors in our methods. I believe we will win. My faith is founded upon the character of those of our own people who are becoming interested in apple eulture and of those who are coming to Oregon from other States to engage in the raising of apples-men and women of much more than average intelligence and education. It is significant that at the two leading apple shipping centers of Oregon. Hood River and Medford. there are strong university clubs. The ranks of our apple growers are being reinforced by graduates of almost every agricultural college in the Union, and by the graduates of many other colleges and universifies. While we are getting more visionaries and incompetents than we want, the evil results following the injection of this mulesirable class will not be permanent, and when they have been eliminated and forgotten then will be found remaining a body of apple growers who would make a success of any business. It is indeed fortunate for the development of the apple growing industry in Oregon that it is attracting so many persons of trained intellects and broad minds-men and women who are not discouraged by obstacles. which may be over. come and who realize that an oceupation is usually worth while just in proportion to the obstacles which must be overcome. The work of fincling the best possible solution of every problem which the apple wrower has to meet will strengthen the mental and moral fiher of every person who does his share of the work. In accordance with the law of attraction communities of intelligent. progressive, apple raisers, animated by the determination to excel, will draw to it more of the same kind. The more people of this kind we can induce to engage in the 
apple industry in Oregon, and the more communities of such people we can obtain the greater our chances will be of surpassing all rivals and the better it will be for all who engage in the apple industry in this State. Horticulture has always had a fascination for the best types of people. Communities made up of men and women who have the mental and moral qualities essential to sucess in the apple industry will raise the standard of agriculture, and bring about a much-needed inrrease of respect for those engaged in this occupation. The good effects of their coming will not die with them but will endure.

\section{Questions and Answers.}

Q. Did Mr. Miller mention the difference in the price of Australian and Hood River apples?

A. I do not think he referred to Australian apples. They come into the market at a different time.

Q. How about the Japanese apples?

A. They do not produce any. He simply said that they can do it. The great bulk of all the apples offered for the markets in Europe are the veriest trash. All that is to keep us in mind what our competitors (an do. Of course France produces some very fine fruit with very inadequate methods. When the Panama Canal is finished it will open up one of the greatest markets for our American apples. It will enable us to lay them down there at reduced freight rates through the opening of the canal.

Q. I noticed that Mr. Miller spoke very highly of the Grimes Golden apple. I would like to ask you to give me a general description of the Grimes Golden.

A. The Grimes Golden is bright golden and of very high quality. Pcmoletically it is below the Spitzenberg. It is not as good a keeper as the Yellow Newtown. Its best period would be just before the Yellow Newtown. It is in its prime about the first of December until the middle of February or first of March. It is a rather small apple, but that is desirable for English markets. They do not want very large apples. In England the holidays are the best time of the year to sell fruit. A little later they get fresh fruits from Cape Colony and from other places that reduce the demand. The Grimes Golden is a very good bearer in the Willamette Valley and is remarkably free from seab.

Q. Do they grow better on low level?

A. I am not sure about that. The last Grimes Golden I had were grown at an elevation of 600 or 800 feet. 
Q. What four varieties would you consider the best for commercial apples?

A. I want to say that when we really apply the doctrine of best in fruit, we must not confine ourselves to apples in the fall. Do not begin with fall apples. with Gravensteins, because splendid Gravensteins can be grown. We must begin to supply our eustomers with Gravensteins and keep it right up as fast as the other varieties come on the market. A great deal depends upon the locality. We have so many high elevations and every elevation materially affects the production of apples. In the Willamette Valley the Northern Spy is the leader. It camnot be beaten in quality in the Coast Range Momntains. Near Scappoose they grow a magnificent Northern Spy. In the Cascade Mountains the color of the apples is not so high as those grown near Seappoose. I cannot believe that people will not buy a good appl" when they find out that they can get a good one; I do not believe they will buy a Ben Davis when they can get a Yellow Newtown, and it comes into the market at a time when its only practical competitor is the Ben Davis.

Q. How is the Baldwin?

A. The great trouble with the Baldwin at present is that is has a peculiar speck, a trouble which we have not yet been able to cope with.

Q. Are Newtowns more profitable than Spitzenbergs?

A. Yes, at least judging from what people tell me. Some of the hereties at IHod River say that the Ben Davis is the most profitable.

Q. Are Newtowns and: Spitzenbergs best on high elevation?

A. The Spitzenberg is best on high elevation. In Hood River the Newtown just overlapped the Spitzenberg; the best district for the Newtowns was 1,100 feet, and from there on the Spitzenberg was best. That is not above the snow line, but pretty far up.

Q. What about the Winter Banana?

A. It is not adapted to the Hood River or Willamette Valley conditions. Where there is no irrigation and dry air it gets sufficient firmness and thickness of the skin to make it possible to handle, but eren at Hood Rivere it is practically impossible to handle it carefully enough that brown spots will not be produced on it, and its main advantage is its beauty. If I am not mistaken, it originated in New Jersey.

Q. Will the Newtown grow at an elevatioon of 2.000 feet?

A. I would be afraid it would not keep long. I have seen them grown at 1.800 feet and they were hard and green months afterward. A Spitzenberg would grow all right at that elevation.

Q. Are there any advantages in growing dwarf apples? 
A. We have not had any demonstration of that here in Oregon. I believe this country is well adapted to dwarf apples. A man at Puget Sound has given a great deal of attention to this matter and he is of the opinion that this country is well adapted to dwarf apples and pears.

Q. What about the Dufur Valley?

A. It was stated at the meeting of the State Horticultural So. ciety that if they had gotten from Hood River a number of competent men to pack the best boxes out of their carload of apples they would have had a magnificent exhibit. As far as the quality of their apples is concemed, I have no doubt but the Newtown is an apple that they should cultivate there.

Q. What is the elevation?

A. I hear it is a slope, probably from 1,200 to 1,800 feet. Being back from the Columbia River some distance, it is not as warm there as if they were closer to the Columbia.

Q. Do the people want this central selling agency?

A. It is a situation of something that has to be done, but we must first have a local organization. The idea prevailed fourteen year's ago that it was an attempt to monopolize the fruit industry. That was 'rroneous. The real aim is to bring about a more even distribution of fruit.

Q. What varietıes are adapted to White Salmon?

A. I am not very well acquainted with the White Salmon sec. tion, but it is so much like IIood River that it would be practically the same. Their leading varieties are Yellow Newtown, Spitzenberg and the Ortley.

Q. How about the Rome Beauty?

A. That is an apple which adapts itself to many different localities. It is one of the very best apples in the high elevations of $\mathrm{Or}^{2}-$ gon, Washington and Idaho.

Q. How about the Ortley?

A. The Ortley is an apple of very high quality.

Q. The Gano?

A. That is a low-grade apple. They are used for baking, but in leality they are not a very good apple. The Wagener is a much better apple and it does very well in the Willamette Valley.

Q. What variety is the best baking apple?

A. Sweet apples are considered the best, but we do not have an opportunity to try them beeause people have gone out of the business of raising them. The baking apples in Portland are the Ben Davis, Gano and Arkansas Black. 


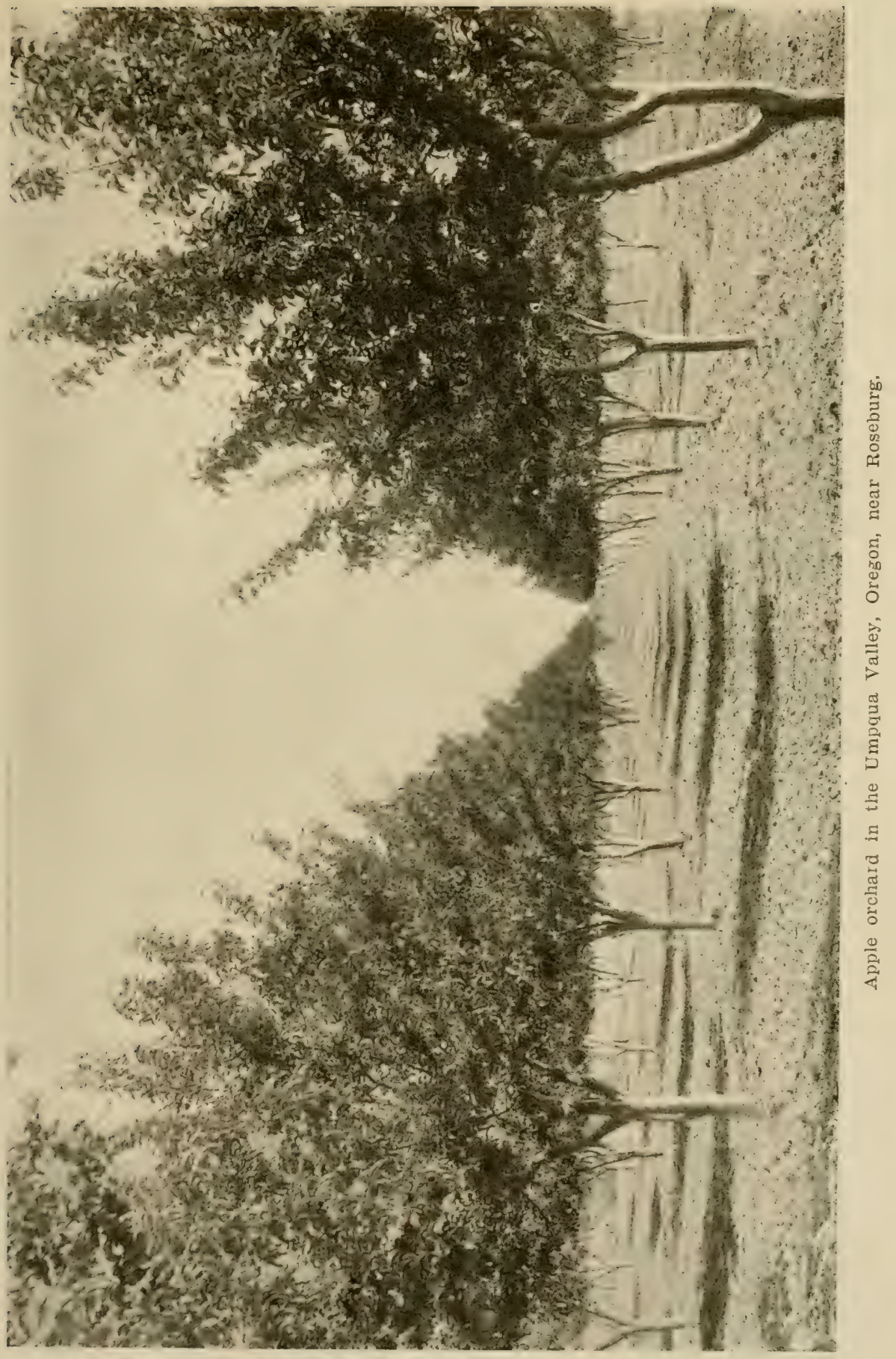




\section{Apple Tree Anthracnose}

Prof. I. S. Jackson. Department of Plant Pathology; Oregon Agricultural College.

Н

REC ENT magazine writer says that all Oregon and Washington are apple mad. In looking over this audience I wonder if he wasn't about right, especially when it is possible on a Saturday night in a large city to get out an andience of this size to listen to lectures relating to apple culture. Perhaps Oregon is apple mad, but so long as om real estate agents and others have provided the asylum in the shape of an apple orchard. I do not think very much harm will eome from it. It seems to me that it is rather unusual to find so many people interested in topies, many of which are as dry and technieal as the one on which I am to speak tonight.

The apple tree anthracnose, as it is commonly called in this State and Washington, is a disease of the apple tree which is peculiar to the Pacific Northwest. It occurs in no other part of the Inited States as a serious disease. Its distribution is as follows: It extends from British Columbia to the Southern part of Oregon and possilhy into California, although that is not definitely known. It oceurs also in Idaho. How far East it is spread is not known. In Oregon it is, with the possible exception of the apple scab, the most serious disease with which apple growers have to deal. The disease is characterized by the appearance of dark colored, sunken cankers which are seen on the yomg growths. These are not found as commonly on the large branches as on the younger ones.

Cankers are first to be observed in the fall or early winter as round, sunken, dark eolored spots which slowly enlarge ant elongate, making little visible growth during the dormant season, but on the advent of spring and the conserquent renewed activity in the life processes of the tree continue to grow rapidly. The cankers are mature in mid-summer and the active spread ceases. At this time the cankers are deeply sunken, dark in color with a limiting crack around the edge. sometimes the cankers are so large that they girdle branches to such an extent that the entire tops may be killed. In rare eases young trees are killed by cankers forming on the trunk. These are extreme examples. As we usually see it, the disease is found to produce few or many cankers on the younger branches of trees, oceasionally girdling a twig or branch. 
The bark in mature cankers is found to be death to the sap wood. After the active spread the bark may cling in the eankers for one or more seasons, finally falling away, leaving an ugly scar which heals slowly. When a number of cankers occur on the branches the circulation of food in the trees is interfered with and the tree suffers.

Apple tree anthracnose is caused by a Parasitic Fungus. Perhaps this may need a little explanation. First let me define a parasite. A parasitic organism is one which lives at the expense of another organism, drawing its nourishment from the "host" on which it is living. The mistletoe on the oak is a very good example and will serve to illustrate a parasite familiar to all and one so large as to be easily seen. The oak mistletoe is a parasite of a high order. It is a flowering plant parasitic on another flowering plant, the oak tree. I have said that the disease under discussion is caused by a parasitic fungus. A fungus is a plant of low order but nevertheless a plant as truly as is the apple tree. It differs from the latter essentially in that it lacks green color and is on this account unable to manufacture its own food and must take it directly or indirectly from some green plant.

The common field mushroom is a fungus familiar to all. It lives on decaying vegetable matter, principally grass roots present in the soil of pastures or fields. Other familiar examples are the shelf fungi and mushrooms frequently seen growing on stumps or from wounds on living trunks of maple or other trees. Fungi in general exist in either one of two stages, one called the vegetative condition, which exists in the substratum or soil on which the fungus is growing, the other is called the reprorlutive stage or fruiting body and bears the spores or disseminating organs of the fungus. The vegetative conclition consists in most fungi of very delicate, colorless threads which are invisible to the naked eye except in mass. These threads branch and ramify in the soil or in the tissues of the plant on which the fungus is growing, absorbing nourishment for the fungus. The reproductive stage must be of various forms, depending on the kind of fungus.

I have spoken of the field mushroom and the fungi rommon on the trunks of trees as illustrative of forms that are large and easily seen and familiar to all. In the fungus causing apple tree anthracnose, we have to deal with a form that we cannot see so readily, one so minute that it can only be studied satisfactorily by the use of the compound microseope.

If a mature canker is examined in midsummer little elevations in the bark are easily observed. They are at first more or less conical in shape and are thiekly seattered in the sunken area. They gradually enlarge and finally burst the outer layer of the hark and expose the cream-colored mass of fungous tissue. These are the ascervuli or 
fruting hodies and bear the reproductive cells of the fungus, which are very minute, curved, colorless bodies. invisible to the naked eye except in mass and are produced in countless thousands in the pustules alrearly described. They are held together during the dry weather by a sticky substance and are only liberated by the first fall rains, when they are broadly distributed by wind and rain, often being carried for long.distances. Moisture is necessary for the growth of these spores, which uider propex conditions grow out into a slender tube which may penetrate the bark of the apple, ramifying in the tissues, killing them and produeing the typical cankers.

It is possible to isolate the organism causing this disease and grow it in pure culture. By taking a portion of such a culture and inserting it in the bark of a healthy tree we are able to produce the typical cankers of the disease. This proves beyond a doubt that the cankers are caused by the fungus.

Infection takes place in the fall at any time after the first fall rains. The great majority of the infection cloubtless oceurs from about the middle of october to the first of December. After infection the fungus spreads but slowly during the fall, remaining practically dormant during the winter and begins active growth again in the spring. The spread of the fungus in the tissues ceases early in the summer and when the canker is mature can only be found in the sunken bark.

There is no evidence to show that the cankers grow in size after mid-summer. It is true that the mycelium or vegetative stage of the fungus remains alive in the bark of old cankers at least till the second autumn after the infection and spores like those produced in the cankers the first year after infection are found in limited quantity. This second year's growth, however, is as a saprophyte on the dead bark which still clings to such cankers. The pressure of another spore stage, the sexual spore which is common in the life history of the fungi of this nature, has not been proven to be present in the life history of the apple tree anthracnose.

Besides the caukers on the branches we sometimes find a disease of the fruit eaused by the same fungus, On the fruit the spots first appear as small, brown, sunken areas which gradually enlarge, producing a rather soft rot. Finally pustules are produced which bear spores like those found in the cankers on the branches. Apple tree anthraenose, however, is not to be considered a serious trouble of the fruit. The spots oceur only when the fruit has been left hanging on the trees for some time after the fall rains hegin. In season when the rains begin early it will he more prevalent than when they ocem later.

In treating a fungous disease of this nature it is important that the tree be covered with some fungicidal substance that will prevent 
the germination of the spores and so keep the fungus from entering the tissues. After the fungus once enters the bark no treatment can be applied that will kill the fungus and not kill the tissues as well. The treatment must be preventive and not curative.

It has been found by investigator's as well as by growers that the only satisfactory method of controlling the disease is by spraying before infection takes place, with the Bordeaux mixture or limesulphur. The spray should be applied as soon as the fruit is picked and before the fall rains begin, if possible. While it is desirable to get ahead of the fall rains, the application may be made any time that the weather permits. In serious cases two sprays should be given two to four weeks apart. Spraying after the middle of December is not recommended. The results of experimentation have shown that the Bordeaux mixture gives slightly better results than lime-sulphur for this disease.

In some seasons it frequently happens that large growers can not spray on account of umsual rainfall and the disease has an opportunity to increase. If the disease is known to oceur in an orchard, even in slight amounts, it will pay to spray every year that the weather permits. Should it happen that the disease becomes serious in a large bearing orchard, spraying once or twice with lime-sulphur as late as possible before the fruit is picked should be tried. This spray will not seriously discolor the fruit.

Badly affected branches should be prumed out preceding the fall spraying. In young orchards where not too large it might be profitable to scrape out the cankers in the winter or early in summer and

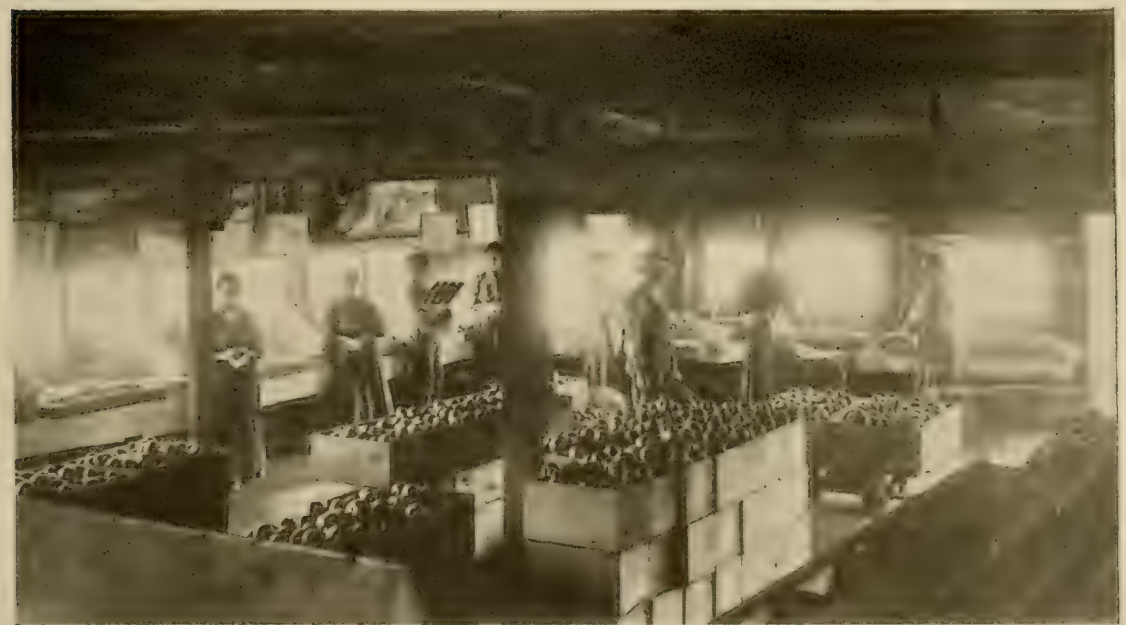

Interior of a packing house in the Rogue River Valley. 
paint over with thick Bordeaux or disinfect with corrosive sublimate and paint over with lead paint.

The treatment recommended will entirely control the disease and should be practiced every year as a matter of insurance, beginning when the orchard is young. If this is done no opportunity will be offered for the disease to become serious.

It is important to note that Professor A. B. Cordley of the Oregon Agricultural College was the first to work out the true nature of the disease and to publish recommendations for its control. Nothing of essential importance has been added to our knowledge since he made his first report, about 1900 .

Note.-Workers in the Department of Plant Pathology at O. A. C. wish to know the results which growers have in carrying out the recommendations given. An urgent invitation is given to all interested to become correspondents with the Department of Plant Pathology on questions relating to apple tree anthracnose, and to other diseases of plants.

\section{Questions and Answers.}

Q. How long does it take the ordinary man to learn to perform the operation of cutting out the disease?

A. Not long; first become familiar with the appearance of the disease and eut down to the healthy bark or to the wood.

Q. Can an ordinary pruning knife be used?

A. Any sharp knife will do. Cutting out would be practical only for young orchards where one can get to all parts of the tree. I have seen large trees with fully 200 cankers on the branches. It would plainly be impracticable to attempt to cut out the disease on old trees in large orchards. Spraying is easier.

Q. Is the disease prevalent in all valleys?

A. I cannot say definitely. It is much more prevalent in some than in others. All sections in this region are liable to infection.

Q. Is this disease anything similar to the apple scab?

A. The apple scab is a different fungous disease. It attacks the leaves and fruits of the apple tree and develops at a different time of the year than the anthracnose.

Q. Does the same remedy apply?

A. Spraying will prevent the apple scab, but, the life history of the fungus being different, the spray should be applied at another time. It is absolutely necessary to know the life history of the organism eausing any particular disease in order to know when to apply the spray. Get ahead of infection. The primary infection of the apple 
scab occurs when the blossom buds are beginning to open. That is the time for first spraying. Spray again after the prots fall and make one or two more applications at intervals of 10 days or two weeks. Use the lime-sulphur.

Q. When an orchard is first set out what is the first symptom?

A. The cankers which I have described.

Q. How soon do they occur in young orchards?

A. They may appear on the trees the first year after setting out.

Q. What is the possibility of their attacking old trees?

A. Very good. Whenever you see an old orchard in an infected region you may be pretty sure that there is some anthracnose unless it has been given proper treatment.

Q. Is there much danger of spreading the disease through the distribution of nursery stock?

A. I know of no case where that has been at all serious, though it is possible.

Q. From the nature of the disease would it be much less liable to spread in that way if one year trees were planted instead of two year?

A. One year old trees would not be as liable to have the disease as the older trees. You would not find cankers on one year trees unless they had become infected before being taken up. Trees are changed so frequently in the nursery that the disease does not have time to get started. This is probably the reason why we do not see them in the nursery. If an old orchard which is infocted with anthracnose is in the vicinity of a nursery, infection may spread to nursery stock. Such an orchard should be cut down.

Q. Does it infect pear trees?

A. A similar canker is found on pear trees which may be due to anthracnose, but if so the life history is not carried out. As far as I know no spores have ever been found in cankers on the pear.

Q. Is the disease liable to attack an old tree for the first time?

A. It may attack a tree at any time. Cankers are more abundant on the young growths, that is, on branches under two or three inches in diameter.

Q. How do you explain the development of the disease in the apple you hold? (The speaker has a diseased apple in his hand.)

A. I broke the tissue of the apple and introduced a portion of a pure culture and kept in a moist place. This was inoculated in about the second week in November. It first developed a small brown sunken area which gradually spread, forming a large spot. The 
mycelium or vegetation stage of the fungus is all through the decayed area. Spores are produced in the pustules on the surface.

Q. Do spores ever attack the trunk of the tree regardless of the age?

A. The trunk may be infected and cankers produced, but if the tree is of any age the fungus cannot grow through the bark so the canker is not typical. That depends on the condition of the bark.

Q. Is the disease more prevalent west of the Cascades?

A. Yes, in Oregon.

Q. Does the growth demand more circulation or retard it?

A. It retards the passage of food to the lower branches of the tree.

Q. Does it thrive in wet or dry season?

A. In the fall during frequent rains there is more infection. It must have moisture and rain to germinate the spores and spread the disease. The spores are slowly developed in the cankers in dry weather.

Q. Is the disease found where there is snow?

A. The disease is limited to the Pacific Coast. It extends up into British Columbia where the winters are severe.

Q. In the old trees where the anthracnose has gotten well started is it possible to reach it and kill it by spraying without removing the outer bark?

A. The cankers are annual. They develop in the spring and into the next summer, then cease the active growth. You must get ahead of the infection. Infection takes place every year, so by spraying this fall you prevent the cankers next summer.

Q. In what strength do you use the spray?

A. In using Bordeaux mixture you may use 5-5-50, or the 5-6-50. This is: 5 lhs. copper sulphate (Blue Stone), 6 llss. stone lime, 50 gals. water. In preparing the lime-sulphur the commereial mixture is diluted 1 to 15. If used on foliage a weaker solution, about 1 to 30 , is recommended. These are the proper dilutions when the stock solution is about 300 Baume.

Q. Does the disease occur on any wild plant?

A. Some years ago Prof. Pierce of the U. S. Department of Agriculture spent some time in Oregon and Washington studying this disease, but he made no official report. In a letter to the late Mr. Wallace, of Salem, he stated that he found what he believes to be the native host. He has never given us any published information. 


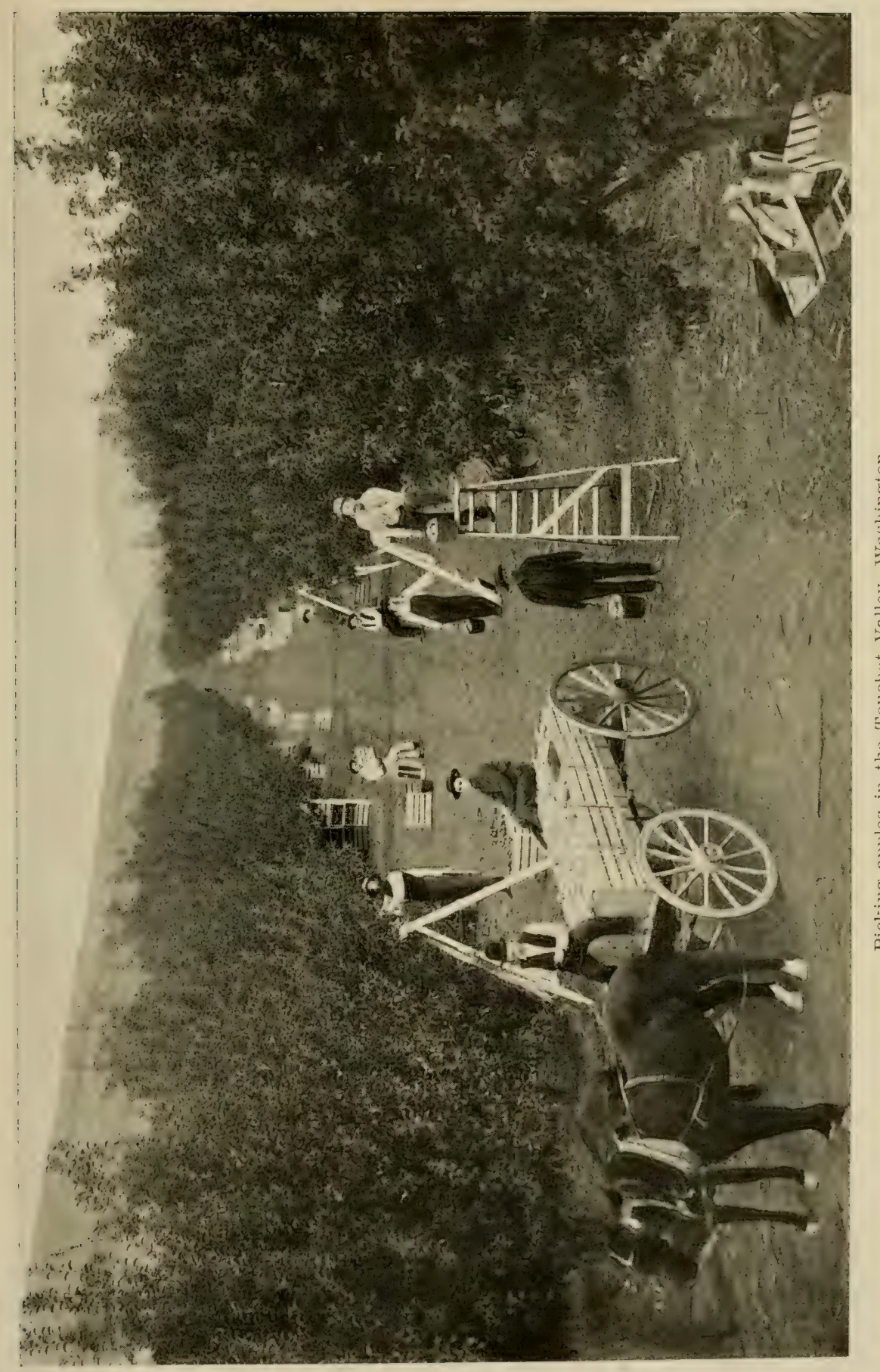




\section{Injurious Orchard Insects}

Professor Hailey F. Wilson, of the Oregon Agricultural College.

$I$

T GIVES me great pleasure to be with you this evening. Taking up the orchard pests, I am going to deal principally with those of the apple. These insects which attack the apple ordinarily attack the pear also, so that we have a list of the principal ones on the pear as well as on the apple.

I will first mention the codling moth, an old and familiar friend with all people who have eaten apples, even though they have not tried to raise them. The worm is found in the apple; later it produces the codling moth. In taking up the subject of injurious insects, I would suggest the advantage of knowing all stages; be able to tell not only the worm and moth. but know the egg and pupa, and try to become acpuainted with the life history of the various stages. Ordinarily each insect passes through four different stages. Some only pass through three. In the case of the colling moth the egg is laid by the adult moth on the leaves or fruit, principally upon the leaves by the first generation of moths which are present in the spring. From these egos hatch little larvae or worms which find their way onto the apples, and, eating through the skin, work toward the center, feeding and finally exawl from the fruit and, seeking a hiding place, pupate, lose all their appendages and do not look at all like worms. After some time there comes forth from this pupal case a little grayish-brown moth known as the codling moth. This is the adult insect.

You are, perhaps, more interested in the remedies for those insects than in the life history, so that I will not spend more time here, but will give the remedies. In the case of the codling moth, as perhaps you all know, we use the arsenate of lead. I will say that in times past it has been the rule to have from one to 15 remedies for most insects. Later investigations have shown that there are probably three different control measures which will do for most all insect pests and plant diseases. These are lime-sulphur, which is now known to be a fungicide as well as an insecticide; the arsenate of lead, which acts as a poison, and what is known as Black Leaf Tobateo spray, which is used as a contact insecticide for summer spraying purposes. That is, it is sprayed on the insects and kills them from the outside, while the poison 
is taken inside and they die from the pusoning. In case of the codling moth there are two generations each season. In order to control these insects it is necessary to spray some three or four times each year. In this State we do not recommend spraying less than three times. Professor Melander, in Washington. I believe, recommends that in some sections of that State one application is sufficent to control codling moth. In this State we give these three sprays as follows: The first one to be applied in the spring when the calrx of the apple blossom is still open, and after the petals have fallen; the second before the calyx closes in order to get the poison into the little calyx cups. It has been shown that about 70 per cent of the larvae of the colling moth from the first generation eat into the calyx end of the apple. When the arsenate of lead is placed in there the larvae eat it and are poisoned. In the Eastern states it has been the rule to recommend spraving about two weeks later. In the Willamette Valley, at least, it has been shown that this spray is of little or no value for the codling moth, as the worms do not come out until about the 25 th of June or the first of July. Of course you will have to be governed by conditions, of various seasons, and the locality in which you live. In the southern part of the State it might be safer to spray the 20th of . June or thereabouts. while at Portland the spray should be applied the first of July. These are general directions only and can be supplemented by a general personal observation. The third spraring is $r^{2}(0)$ mmencled to be given about the 10 th or 11 th of August. that is. aceording to experiments carried on hy Professor Cordley. That might not be true of all sections. and probably will vary from the list to the 201th of the month. During ordinary seasous we recommended a fourth spray to be given about the first of September. This not only helps control the colling moth, but also catches many other inserots, the prin(cipal one being the but moth. This insect feeds in the spring on the buds. The secomd generation, which is produced in the fall, feects on the under side of the leaves of the apple, pear and other fruit trees. Now, if the leares are thoroughly sprayed about the first of September. and the spray gotten onto the under side of the leaves it will catch most of the worms of the second generation. The hud moth spends the winter as a half-grown larva, similar to that of the codling moth. In the spring it comes out of its winter cocoon, works and feeds upon the tender young buds. Instead of feeding on a single bud and destroying that bud alone, it goes from one bud to another, feeding a little on each, so that a single worm will in one night destroy a large number of buds. Should there be from 15 to 20 or 25 of these worms present on one tree there would be a corresponding number of buds ciestroyed in a short time. It feris only by right. remaining hidelen 
in the day time in its nest of leaves. In making its nest, the worm draws the leaves together by a small thread of silk which is secreted by the worm itself. Toward evening, when found feeding, if they are disturbed, they will crawl back into the nest and remain hidden for some time. The recommendation for spraying as ordinarily given is in the spring before the buds open or about the time they are turning green. At that time arsenate of lead, two pounds addeci to 50 gallons of winter strength lime-sulphur or 50 gallons of water, may be applied. Probably a better time to spray is in the fall, about the first of September, so that you have a codling moth spray and a hud moth spray at the same time. Should it be found that the fall spraying will control the moth the spring spray may be omitted.

Only recently has lime-sulphur come into general use as a fungiride, and now it is generally used as a combined spray for insects and plant diseases. At the proper time for spraying for the codling moth, first application, apple scab can also be treated, and at the present time arsenate of lead and lime-sulphur are combined and applied at the same time. To each 50 gallons of lime-sulphur 30 degrees Beaume diluted 1-10, a pound of arsenate of lead is added. If apple scab is not present, water may be used instead of lime-sulphur, as the latter is apt to burn the leaves.

I will speak of the San Jose seale only in a very general way, because it causes very little damage where spraying is carried on thoroughly. The seale, as we see it and know it, is a grayish, hard seale, under which lives the tender living insect, principally on orchard trees, although the San Jose seale is found on some 100 or more plants. It spends the winter in an immature condition, developing in the spring into the full-grown insect. At that time the males come from beneath their sealy covering and fly about fertilizing the female scales, which latter produce a large number of little yellowish young. This number has been estimated as high as nearly 500. It takes about 33 days for these to mature, so that we have in Oregon about five or six generations in a year. If, in each of those generations a female seale produces about 500 of her own kind, you can see what an enormous number you would have at the end of the season. Ordinarily, spraying as applied for apple seab and anthracnose will keep the scale under control, and where spraying for this purpose is earried on $I$ do not helieve it will be necessary to apply a special spray for the seale. IIowever, in case you should take hold of an old orchard which has not been sprayed for some time and the trees are rovered with seale, other insects and moss, I would recommend a winter spray of lime-sulphur 30 degrees Beaume, diluted one to eight or ten. This can be applied at any time during the 
dormant season of the tree. The next season you will, perhaps, not need to give the regular spray for scale, depending upon the other lime-sulphur sprays to keep the scale in check. It has been the usual method to apply the seale spray in the middle of the winter while the trees are in a dormant condition. Upon investigation it has been found that in the spring or fall the scale is more easily lilled. As it is much easier to control other insects by spraying in the spring, it is recommended that the winter spray be applied as a special spray when the buds are turning green. The spray for anthracnose should be applied in the fall, just after the fruit has heen picked. This will, perhaps, do more to kill the seale than any other spray.

Professor Wilson was asked: "Where does the codling moth spend the winter?" and replier?: In a half-grown, or two-thirds state, in a cocoon which it spins in the fall. They are under the bark in erevices, on the ground, under clods or boards. If you want to make an experiment to find their cocoons, in the fall tie a cotton sack around your tree, and then go out during the winter some time and remove the band. You will perhaps find a number of cocoons. An orchard which is not well taken care of, on which the moss is thick, is an ideal place for the codling moth to live.

Next, I wish to speak of some apple borers which attack young apple trees two or three years old. Perhaps some of you have noticed the trees as you go into an orchard in the fall. Upon examination you will find that your trees are dead, and, upon close inspection you will find at the base of your tree a worm with a broad, flat head working in a wide channel just under the bark. There are two kinds which ordinarily attack the apple. The one which is so injurious in Oregon is not so injurious in the Eastern States. The one which is injurious in the Eastern States is not at present found in Oregon. This borer passes through four stages, but the adult is a beetle and not a moth. It is a kind of a brown beetle, about half or three-fourths of an inch long. The eggs are laid in the summer on the bark. A little worm hatches out of the egg and bores into the bark next to the wood, and works around the tree, that is, it bores up and around, and then back down. As the worms grow, of course, the channel becomes wider, and sometimes you will find a channel at least half an inch across, which is very apt to cause the death of the tree. After the borer has once entered the tree there is no way to exterminate it except to dig it out: The best remedy is a preventive means. The best way is to tie the paper around the tree, that is, old newspaper or some of the commercial panels, as they are called. In using these you should place some cot- 
ton around the tree at the top of the panel to keep the borer from getting in under. At the time the paper or the panel is used, the dirt should be piled up and around the tree, so the adult cannot crawl in under. Wire screen has been recommended placed about the tree and tied at the top. If this is used, it should be so arranged about the trunk that the beetle cannot deposit eggs through the meshes of the screen. When the papers are tied to the trees the string should be rather loose, so that should the trees grow very much or expand during the summer it will not bind the trees, and the strands can be broken, otherwise you might injure the tree.

\section{Questions and Answers.}

Q. When do they attack the tree worst?

A. During the summer, but the injury does not appear until fall. At that time the larva has finished its work. It bores into the tree and remains there until spring, when it comes forth as the adult beetle. When the larva first starts the channel it is very small. Later in the summer it may extend around the tree. Toward fall the larva bore into the center of the tree and pupates.

Q. In setting out trees the first year it has been my experience that before they got established the borers attack them worst.

A. This seems to be the case. The borers attack the trees when they seem to be in a weak condition. When you set the tree out it has rather a setback, beeause it has been taken up and replanted, and it has a harder fight to make and so the borer has less trouble in making headway.

Q. Is whitewash any protection against a borer?

A. Yes, to some extent. To what extent I would not be able to say. Whitewash when ordinarily applied, no matter how thick, will crack, and the borer deposits the eggs through the cracks next to the bark, but the whitewash will be of considerable benefit, and when whitewash is used, some carbolic emulsion, such as crude oil or something of the kind should be applied in whitewash, say half a gallon to a barrel of whitewash. The odor seems to keep them away to some extent. Ordinarily in orchards where weeds and grass are allowed to grow elose to the trees, you will find mere borers, as this offers a hiding place for the beetles in the daytime and they deposit their eggs unmolested. Weeds should be kept down.

Q. Is that beetle found very much in this state?

A. Yes, that beetle (the flat-headed borer) has been known in 
the state since 1893 or 1894 . As from time to time new orchards were set out-more young trees-more reports have come in. A number of people who attended the recent short course at the O. A. C. spoke of damage caused by this species.

Q. What sections are worst?

A. I do not know that any one section is worse than another. The majority of reports have come from the Willamette Valley.

Q. Do you have any reports of the round-headed borer?

A. The round-headed species, as far as we know, do not exist in this state at the present time. The flat-headed borer is the one we are discussing now.

Q. Have you found that these beetles work where ground is first cleared?

A. Well, I would not think so, except in cases where a young orchard adjoins an old orchard. I would not recommend raising nursery stock near an infested orchard because it affords abundant feeding ground for the beetles.

Q. About what age do trees become immune?

A. They will never become immune. The borers seem to start work in this state when the trees are about two or three years old and that would indicate to me that it is about the time the trees are set ont.

Q. That beetle has done a lot of damage in the East, has it not?

A. Not this particular one. It has been known to cause a little damage from time to time. The round-headed borer in some seasons works in nurseries so bad as to destroy half the trees. In one case a man found 30 beetles in one tree (in an old tree in an orchard).

Q. What would be the objection to using tar paper?

A. There have been reports from those who have tried it that it causes the death of the trees; others say that it does not damage them. To be on the safe side, we do not recommend tar paper.

Q. How high should the paper be?

A. As high as the first limb; 15 or 18 inches from the ground. Put some whitewash on above that for a way and the beetle should not attack them, as they would not go through the paper.

There are a number of insects which work upon the leaves of the apple; one of those, known as the apple tingis, gets on the under side of the leaves, and when very abundant do considerable damage by causing the loss of vitality. In appearance they are flat and nearly as broad as long. Under a hand lens, the wings appear like fine lace. Those insects are somewhat hard to control, but ordinarily can be kept in check with an application of what is known as black leaf tobacco spray, and applied about one to 50 . 


\section{Plant Lice on the Apple.}

While there may be a few other species of plant lice attacking the apple in Oregon, only the included species seem to be causing any serious damage. At least two of these are known to attack both the apple and the pear, and the same remedies will apply on both kinds of trees.

\section{Green Apple Aphis.}

This apple pest lives entirely upon the apple, pear and related plants and does not migrate to grasses, woods and vegetables, as do probably the following species. The eggs are deposited in the fall upon the young shoots of the trees and water sprouts, the latter being the favorite. The eggs hatch the following spring into small green lice, which are known as the stem mothers. Upon hatehing they go to the tender buds, where they feed and develop into mature forms. The spring forms and all following generations of the summer months are females which produce living young instead of eggs. The first generation are all wingless, but later in the spring many lice appear and these migrate to other trees, where they start new colonies, mostly wingless. During Oetober and November males and egg-laying females are produced, and the females lay the eggs which are to carry the insects through the winter. When first laid the eggs are green. but they soon change to a shiny black. The unwinged females are light greenish in color, with black honey tubes and dusky atennae. The winged females, which are the majority forms, are greenish in color with a head and wing-bearing portion of the body black.

\section{Remedies.}

These are properly discussed under early spring, winter and summer sprays. Winter or early spring sprays: Lime-sulphur used, winter strength (1-10 or 1-12) will undoubtedly kill many of the eggs, but to get the best results, this application should be made just as the buds are turning green. At that time most of the eggs will have hatched and the young are more easily killed than are the eggs. Black leaf, diluted one gallon to 40 gallons of the spray, may also be added if the lime-sulphur does not seem entirely efficient or it can be diluted with water instead.

Summer Sprays.-No definite date or time can be given for these sprays, and the only recommendation that can be made is to spray when the lice become abundant. Black leaf seems to be the most 
favored spray at this time, and when applied one to 60 seems to be thorcughly efficient. Black leaf " 40 ," which is supposed to be a concentrated form of black leaf, is now recommended in place of the black leaf. Kerosene emulsion, containing 6 to 7 per cent of oil, is probably as efficient as black leaf and is cheaper, but needs more time and care in preparation. When used it should be properly made and thoroughly emulsified. Since these species cause the leaves to curl and is protected by them, the best results are obtained by spraying early, before the leaves curl badly, or, if later, the spray should te applied thoroughly and with considerable force to reach the lice.

\section{The Brown Apple Aphis.}

From observations and reports it would seem that next to the woolly aphis the brown apple aphis is, perhaps, the most serious plant louse attacking the apple in Oregon. This species not only feeds upon the leaves and the new growth, but also attacks the fruit spurs and fruit, the greatest damage being done to the spurs. Most of the attacks, however, are confined to the inner portions of the tree.

Dr. Britton states that the eggs are smaller than those of the green apple aphis, and one often needs to hunt carefully in order to find them at all, as they are hidden around the buds, sometimes partly

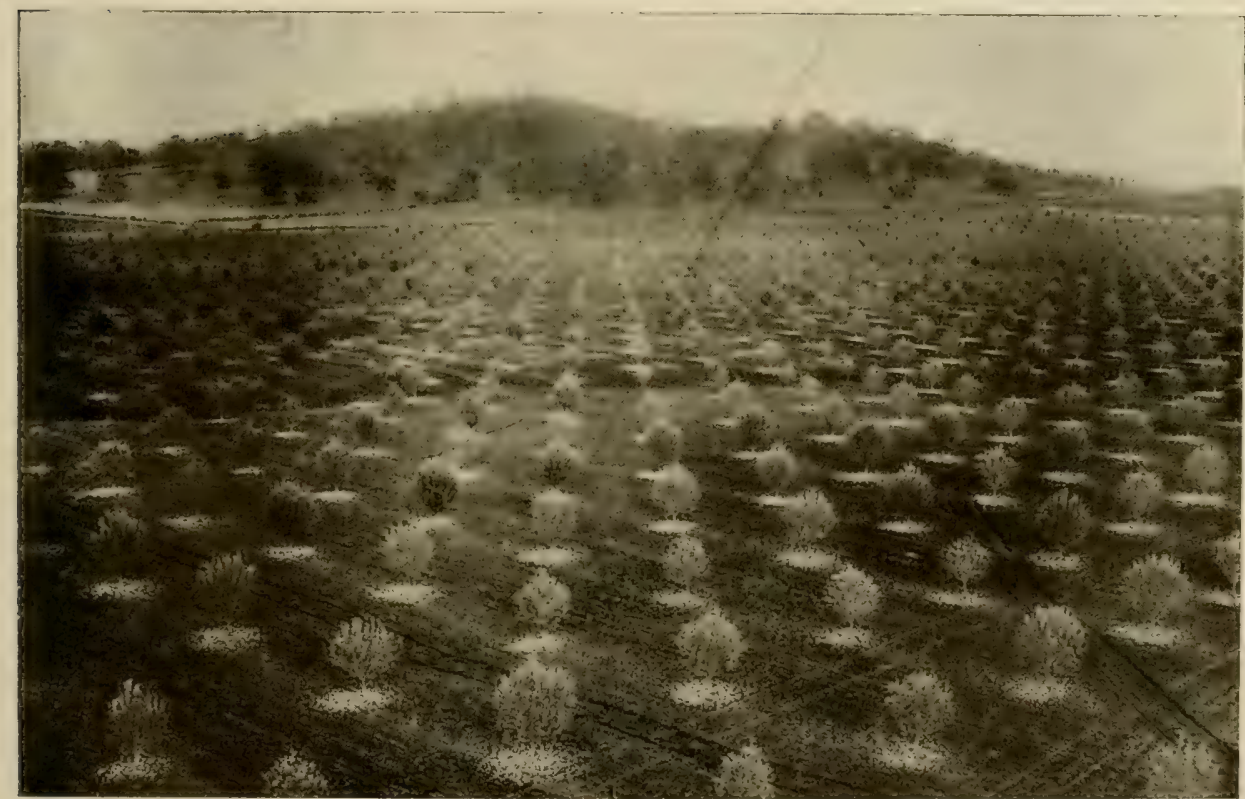

Orchard, near Medford, Rogue River Valley, Oregon. 
under the scales. In Oregon, observations have led us to believe that the brown apple aphis sometimes lays numerous eggs on the young shoots, among those of the green aphis and that the eggs eaunot be readily separated. The eggs of both species hatch at the same time in the spring and the young can easily be separated before they have grown much. Hatching begins just before the buds open. The young lice crawl into the expanding buds and feed upon the blossoms and young fruit. These are the stem mothers and are wingless. Later generations become winged and migrate to some unknown summer food plant, but not until very serious damage has been done to the fruit, as well as to the fruit spurs. In the spring both the winged and the wingless forms are brownish red with a yellowish tinge. The winged forms, however, of both spring and fall have black heads and that portion of the body to which the wings are attached is also black. In the fall both forms are rosy red with a greenish yellow tinge. The same sprays which are used for the green apple aphis also apply to these species.

\section{The Woolly Apple Aphis.}

(Schizonoura lanigora.)-This species is not ordinarily a leaf feeder but may, when abundant, be found on the stems of the leaves and on young apples. The feeding in general is confined to the bark of the parts above the ground, or on the roots below the surface of the soil. At first glance a number of these lice feeding together in an old scar or on a young twig appear like a small mass of moving cotton. Upon close inspection this mass will be found to contain numerous individuals covered with white waxy substance which take the shape of threads, and which serve as more or less protection to the louse, althongh they can be easily rubhed off, thus exposing the purplish brown body to view in each group. In the fall of the year, winged individuals may be noticed. The wings appear dusky and project straight out from the cotton masses.

There is a wide difference between the life history of this and the preceding species, in that some of the lice attack the roots, as well as the upper portion of the tree. Professor C. P. Gillette, of Colorado, has shown that in the spring there may be four means of starting the summer infection. First, by the individuals which have lived over winter in the parts above ground and hidden in old wounds or scars; second, by the early hatching of the stem mothers; third, by the numerous immature lice which may hibernate over winter at the base of the tree near the surface of the ground; fourth, by the overwintering halfgrown individuals which spend the winter on the roots and migrate 
upward in the spring. These conditions are brought about in a very natural manner, and vary in different climates, as the regular habit of the insect would be to produce eggs in the fall, as do other species of his family. Those individuals which are able to live over in the old scars and at the base of the tree are considerably protected from cold, as are also those about the roots. The root form probably instinctively seeks for the roots, both because of the protection from the enemy and because of the better feeding conditions. The lice which appear in the spring and through the summer are all wingless and the winged forms do not appear again until in the fall. Anyone who has observed badly injured trees ean hardly fail to see that the many knots or swellings formed on the roots, trunks and limbs, are not natural, and that the vitality of the tree must be greatly reduced. The root injury is perhaps the most serious, as the roots often die and become decayed, thus weakening the support of the tree, and partially entting off the food supply. The remedies should begin with a thorough inspection of the nursery stock when received; any clots of dirt hanging to the roots should be washed off, and if any lice are found either in the roots or top, the stock should be thoroughly sprayed with or dipped into limesulphur. On parts attacked above ground any spray which will kill other plant lice will also destroy this species.

In conclusion I wish to say just a few words about bee-keeping in connection with fertilization of the orchard. In order to get good fruit you must have cross fertilization. In order to carry the pollen from one flower to another you must depend upon the insects largely to do it. I think it is only a question of time when every well-kept orchard will have one or more hives of bees. We have at the college for the first time a department of apiculture in connection with orcharding as well as keeping bees for profit. 


\section{The Codling Moth}

\section{Professor A. B. Cordley, of the Oregon Agricultural College.}

ণ

HE very fact that so many have come out tonight to listen to a talk on such a dry and uninteresting subject as the codling moth certainly speaks well of the interest in the subject of horticulture, and that argues well for your future success. I do not know whether there is any phase of the subject that is more interesting than the consideration of the various pests, and it has been my fortune or misfortune for the past 15 years to be brought face to face and hand to hand with the problem until I see pests in all directions.

I suppose, however, that in taking up any line of work we Americans realize that we must take the bad phase with the good, and really, in a sense. I suppose it is the spirit and energy with which we go at the control or the removing of an unfavorable condition that makes us so generally successful.

I suppose the first topic that you will be interested in regarding the codling moth will be that feature that is sometimes brought up by the various real estate agents that the codling moth is not so likely to be present in some localities as in others, or that some particular region is likely to be immune from this insect.

It has been my experience the past 15 years in this state, from the fruit-growing standpoint, that it is a region that is immune from the codling moth to a certain extent, but not enough to justify anyone to advertise this in reference to growing apples. The codling moth is a cosmopolitan pest. It eame to us from the Mediterranean regions. It is a pest in all apple-growing sections wherever the apple is grown in a commercial way, from South Africa to Southern Siberia and from Australia to Nova Scotia, and we would naturally find it within the borders of Oregon. A region that would be absolutely immune from the codling moth would not be possible. It is not a fact because it is not true. I do not mean to say that in all regions of the state that insect will eause the same proportion of damage to the fruit, because that is not true. The advantages of some localities arise from climatic conditions. We demonstrated very conclusively that it is not likely to be a serious pest where the evening temperature in spring drops below 60 degrees. Eggs are deposited mostly in the evening, and it is very rarely that eggs are deposited where the temperature is below 60 de- 
grees, so we are not likely to find that the codling moth is as injurious as it is in the warmer valleys; not even in the Willamette Valley as it is in some other valleys in the state. In other words, wherever we find the evening temperature early in spring ranging for a good portion of the evening about 60 degrees, there is not the same amount of injury to the fruit as in warmer elimates.

That is about all there is to the immunity claim. The codling moth is an insect known most widely, of course, as an apple pest, and it destroys in a commereial sense anywhere from 5 to 10 per cent of the fruit in orehards not properly cared for or properly sprayed. In the Willamette Valley I presume today a very rough estimate of the injury to an uneared for orchard is possibly about 35 per cent-some years less, some years more; some orchards less, some more. I notice in some of your old-time orchards it destroys from 75 to 100 per cent, but not far from $35 \mathrm{per}$ cent would be the average. It is an insect which anyone going into the orchard business must be prepared to contend with.

There is no line of industry that calls for more study or thought than agriculture in general, and there is no particular branch of agriculture that requires more eare and attention than horticulture, and there are none of the problems of the horticulturist more involved than those to keep the trees in good health and produce a crop free from defect.

Therefore it is, I believe, that the more any orchardist can learn of the history and habits of the various pests he has to fight, the better success he will have in his warfare. I shall speak for a few moments on the life history of the insect, so you can better wield the rod that has the spray nozzle on it. It can be pictured as a circle. The codling moth, like many other insects, passes through four stages: The egg. the larva or worm, the pupa and the moth, and those four stages, taken together, form the circle, the generation of brood, and since that complete circle is finished or completed twice each year, from the egg to the codling moth, it is said to be two-brooded. There are two complete circles or generations, hence the insect is two-brooded.

I will illustrate by slides the various stages of the insect. The larva or worm is about three-fourths of an inch long when fully grown, and of a pinkish color. In the fall these larvae leave the fruit and seek some place in which to pass the winter, and it makes no difference whether we are in the south, where the codling moth is threebrooded, or whether we are in the northeastern part of the I'nited States. where it is one-brooded, or in Oregon, where it is two-brooded. It has always wintered in this state. It seeks some secluded spot under the bark, or in the erevices about warehouses or storehouses, anywhere 


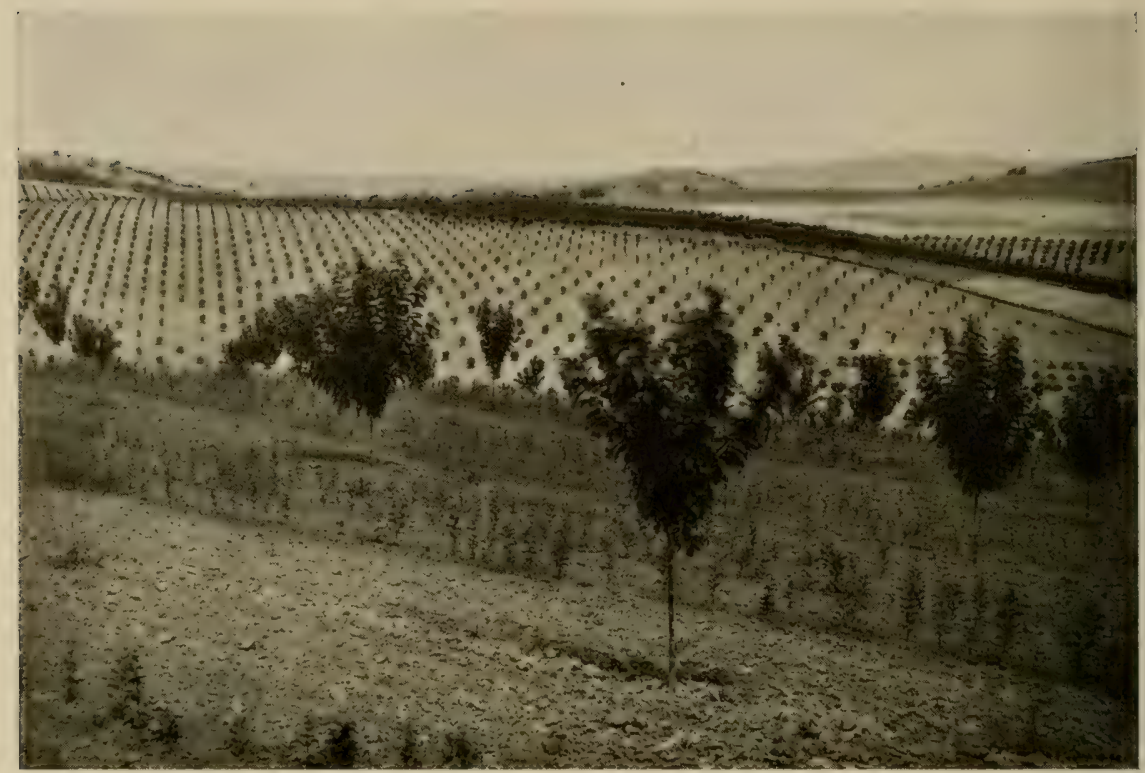

Orchard, near The Dalles, Oregon.

that it can find shelter for winter, and there spins a little white silken cocoon, in which it passes the winter. If you go into your orchard and carefully search under the bark (in most of them you will not have to search very carefully), you will likely find under some of the scales these silken white cocoons, but you will not find the insect this time of the year. It will be in the cocoon, but it will still be in the larva or worm form. It will remain in that condition for some time. I will not go into details right now.

Later the larva changes to the pupa, and then to the moth. Now in a general way we may say it will remain under the bark, depending upon the climatic conditions, until late in February or possibly until April 1. Then the larva changes from the pupa to a quiescent form in which it remains for a variable length of time, depending upon climatic conditions, but on the average about four weeks, and then gives forth the moth. Tou will never find one on the outside of the bark. They will always go under to be protected from the inclemencies of the weather.

In some unaccountable way, I suppose we entomologists are responsible for the belief that there is a direct relation between the time when these moths appear and the time when the spray pump should be started. We shall see later that this is not true. These moths may begin to appear as early as April 10 , and they continue to appear up to 


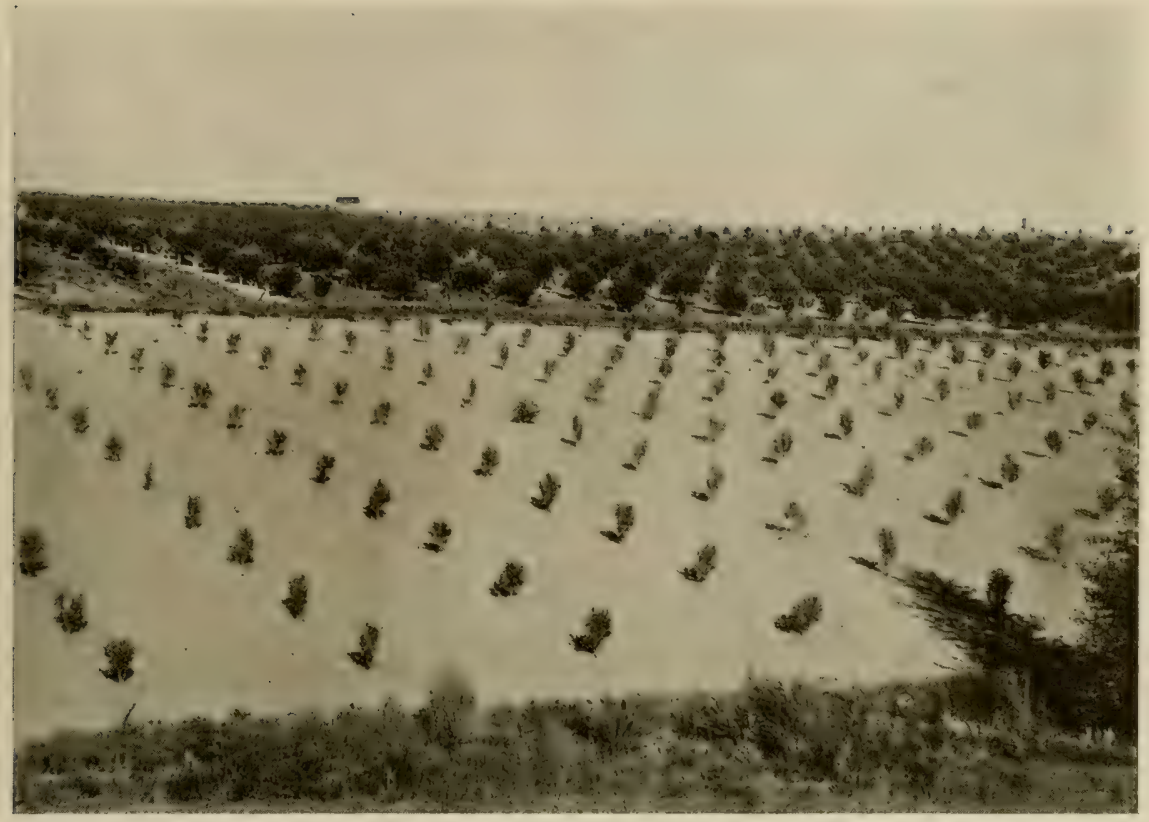

Young apple orchard, Yakima Valley, Washington.

as late as the 10th of July. Hence it is that the relation between the appearance of the moth and the time of starting the spray pump is not a close one, for early moths in this state, that is, those which come cut during the cold, rainy weather of spring, usually die without depcsiting eggs. It is only the later ones that are of any interest to us from an ceonomic standpoint. These which emerge from the 15 th of June to the 15 th of July deposit eggs. Rather than one should pay any attention to the time at which the moths appear, I would suggest that it would be a good plan for every orchardist, if possible, to become acquainted with the eggs of these insects and learn when they are deposited in their particular locality. No one can tell you, because it varies with the seasons and with the particular location of the orehard. At Corvallis these eggs are deposited ordinarily not much before the 25th of June, and from then on to possibly the middle of July. It used to be stated that the eggs were deposited in the calyx of the apple. That arose from the fact that a large proportion of the worms enter at that point. Very, very few, indeed, of the eggs of the codling moth are laid upon the fruit at all. They are laid upon the leaves, and the young larvae at a certain time feed upon the leaves. If they would continue to do so, I would bear with them with patience, but those that are hatched upon the apple, or even hatched upon the leaf and 
by migration finally reach the apple in search of some seclusion to protect them from their enemies, amount to about 35 per cent when they enter the blossom at the calyx end.

This illustrates a very nice point that was brought out in our experiments some years ago. There has been a question whether the codling moth would live through the season if there was no fruit. It has been suggested that in restricted localities, where there was a practical failure of the fruit crop, it would be advisable to destroy what few apples were on the trees. We tried it at Corvallis, experimenting with them all through one summer. In attempting to hateh some eggs upon leaves. We found that the worms began to feed upon leaves after hatching, and I carried them nearly to maturity. Some have bred them clear through the generation depending upon the leaves. The first attack of the codling moth is often made upon the side of the fruit, usually from 30 to 35 per cent.

Very shortly after the larva has hatched it travels all over the fruit. Usually it enters at the calyx simply for the reason that it can get better protection. It feeds immediately under the surface for two or three days, and it then begins to bore toward the center of the fruit. It spends from three to fonr weeks in the fruit, often less than that, depending upon the weather. This represents the first attack of the larva in the calyx by which it enters the fruit. It pushes off a erust which serves for a protection to the larva by preventing the entrance of parasites to its door. It is rather an unsightly mar to the fruit, but gives a good indication to the wormy fruit, and really becomes of some value in attempting to cull it out when packing.

After becoming fully grown the larva bores through the core of the apple, where it has been feeding. to the side of the fruit for the purpose of emerging. It then builds a silken weh orer the entrance. and goes back into the fruit and stays a couple of days, mutil it is fully developed. Then it leaves the fruit and falls to the ground or crawls down the hranches seeking for some place under the sealy bark in which it can pupate. One of the old methods usually recommended for controlling this insect was to pasture sheep and hogs in the orchard to destroy the wormy fruit, but this is only a very imperfect remedr. owing to the fact that a very large proportion of the larva do not fall to the gromud. but seek pupating quarters in the tree itself.

Now I will attempt, if possible, to show something of the relation of the life history and the methods that we shall employ in spraring. and I may say at the hegiming that there are at least three well defined methods of spraying for the codling moth. In 1876. I believe 
it was, Professor Cook, of the Michigan College of Agrieulture, who recommended to some New York orchardist that he spray his trees with paris green for the purpose of destroying canker worms. No method of spraying for codling moth had been discovered by this time, so this spraying was for an entirely different insect. The orchardist followed Dr. Cook's directions, and noted in the fall that he was comparatively free from the codling moth, and reported the condition to the state meeting of the New York State IIorticultural Society. Professor Cook followed it up the next season and for several years afterward, repeating the experiment, and found invariably that the practice gave good results. Now Professor Cook, lik" all entomologists of the time, thought the eggs were deposited in the calyx, and that the larva all entered at that part, and that the only way to kill the moth would be to spray at the particular time that the eggs were being laid, and so he stated in his publication, and advised orchardists to spray early, immediately after the petals har fallen, and that advice has been followed by Eastern orehardists and entomologists ever since with remarkably good results. So you will find the Eastern method consists of applying a mist-like spray just after the time the petals have fallen.

When I came to this state, 15 years ago, most of the orchardists of Oregon were following the Eastern method, and obtaining very indefinite results. I remember speaking at a Farmers' Institute the first winter I was here and the statement was made that it did not give satisfactory results, and for several years $I$ was at a loss to find out why that was true. I saw it was true because in our experiments at Corvallis we did not get satisfactory results in following the Eastern methods. Then at Corvallis we found that under the conditions we have here there is considerable difference where spring comes rapidly and suddenly. Under such conditions the eggs of the moth are deposited usually within a comparatively short time after the petals have fallen. Here in the Willamette valley the blossoms usually are all off by May 10 , and it is very rare that eggs are deposited before the 1utn of .Jume, and the larva does not begin to enter the fruit until the 1st of July, and that suggested to me that we should supplement the Eastern prartice by late spraying, and upon trying that method we obtained much better results.

Within the last four or five years Dr. Ball, of the Itaho Experiment Station, and Professor Mylander, of the Washington station, advised another method which gives most excellent conditions. It is known as the one-spray method, and is exactly the same as recommended by Professor Cook, of Michigan, with the exception that Professors Ball and Mylander's methods of applying the spray are 
with a great deal of force, and applying it in the blossom. Professor Ball was first to call attention to the fact that the calyx of the apple consists of two cavities, but that there is one cavity above the stamen and another below, and he made the further discovery that the larva very largely feeds in the lower cavity, and if we apply the spray in the form of a mist it is not effective, as it does not enter the lower cavity and hence becomes valueless. He therefore suggested that the spray should be applied with a great deal of force, with the idea of breaking down and filling this cavity.

I am free to say that in our work at Corvallis we have not been able to obtain as good results under our conditions, and I was very much gratified in a way to receive substantiation of the results that have been obtained by the United States Department of Agriculture in the East, because I just read the latest bulletin which has been issued by the department, giving the tests of four orchards in the East, and they find that the results are not as satisfactory. I attribute the good results obtained by Ball and Mylander to the peculiar conditions which are found in the semi-arid regions. Under the conditions in which we spray in this state there is no particular advantage in following the one-spray method because we have to control by spraying methods more than the one pest. We have the moth, apple scab and anthracnose and, if we must spray more than once, it is very little added expense to add the arsenate of lead, the poison, to this.

The practice then which we follow and which we recommend for Western Oregon at least is to spray right after the blossoms fall with the arsenate of lead, 2 pounds to 50 gallons of water and 50 gallons of lime-sulphur solution, because therefore we make a combined spray and apply directly after the blossoms have fallen. We could then omit all further spraying until about the first of July, because there is no need of making a spraying between the time the petals fall and the time the larva begin to enter the fruit which is about the first of July. That is the time you want to begin this supplementary spraying that is so valuable.

The whole theory for spraying for the codling moth is to have the whole fruit covered with the spray so that the first meal taken by the young larva will be a poisonous one. If we could do this first spraying thoroughly enough to destroy all of the larva of the first generation, of course we would have none of the second, and no later spraying would be necessary, but we have found it impracticable to do this; so about the first of August we make still another spray of arsenate of lead in water with the lime-sulphur; and if these applications have been made thoroughly that will probably be all that is necessary. We found that three were all that were necessary at Corvallis. 


\section{Questions and Answers.}

Q. What is the remedy for the San Jose scale?

A. Spray with lime and sulphur in spring or fall.

Q. Does this apply to Hood River?

A. Yes, but they have other pests beside the codling moth, so it is advisable to use the other sprays.

Q. Do you start with a fine spray?

A. Personally, I recommend the mist or the briny spray. As a matter of fact, when it comes to spraying for the codling moth, I think it makes very little difference. It is a question of doing thorough work.

Q. What bearing has altitude on these pests?

A. I think it has no influence whatever. When you go into an altitude that will affect pests, say below 60 degrees up to the first of June, it would not be practical for fruit growing. I do not know any place where apples can escape the codling moth.

Q. How many pounds pressure are necessary for the pump?

A. 175 or 200 pounds for the driving spray. 125 to 150 will do for the mist spray. 100 will do, but you will not get as good a spray.

Q. Does banding the trees for the purpose of collecting larva do any good?

A. If I were to go into an old, neglected orehard and attempt to bring it up I might practice banding for the first season, but it is not a practice that can be recommended because it is too expensive. By spraying one can reduce the injury to less than 5 per cent, and it hardly pays to go to the expense of banding. There are practically no orchardists in the state who do it.

Q. Will you state again the proper time for the various sprays?

A. The first spray should be made within a week after the petals fall. Use two pounds of arsenate of lead to 50 gallons of water and 50 gallons of diluted lime-sulphur solution.

Q. How strong do you make the lime-sulphur solution?

A. If it is of 30 degree test dilute the one gallon to about $30 \mathrm{or}^{\mathrm{r}}$ 35 gallons of water. The second spray should be applied between the 25th of June and the 1st of July. The third spray would be the 1st of August. A fourth spray may be used about the 1st of September. However, the value of the experiments made at Corvallis does not seem to justify the fourth spray.

Q. What do you mean by spray testing?

A. We use a little instrument called a hydrometer, which you 
can obtain for 75 cents, to test the specific gravity of the liquid. If on the scale it reads 30 degrees it is about a standard lime-sulphur solution. In using the arsenate of lead with lime-sulphur solution there is one condition that you want to guard against. When applied on very hot days it causes some loss of fruit. It does not cause rust; at least, we have used lime-sulphur four seasons without having any rust. Bordeanx mixture used with other mixtures is likely to cause rust. In fact, the danger of this is so serious that $I$ ean hardly recommend that spray in the Willamette valley.

Q. Can you use any spray for the codling moth that is in a mixture?

A. Yes; you can use arsenate of lead and black weed spray. That is a tobacco compound that can be used about 1 gallon to 60 gallons of water; say 60 to 75 . The manufacturer of the black weed has now put a still stronger solution on the market, the black weed 40 , but I have not tested that.

$\mathrm{Q}$. If the season is backward and the petals late, would you then use the second spray?

A. Yes; I do not believe the fall of the petals has anything to do with the time that the moths lay their eggs. We usually find that the petals are all off by the 10th of May at Corvallis. Very rarely indeed does any egg-laying begin before the 25th of June.

Q. What make of spray nozzle is the best?

A. I do not believe it makes much difference.

Q. Would you recommend one that would throw a mist?

A. I am frank to say that I like the mist spray. There is less danger when you use a mist spray than when you use a heavy driving spray. rate?

Q. Would there be any advantage in spraying at the present

A. There is no benefit from the codling moth. There might be a little advantage in spraying for anthraenose at this time. I would wait until spring.

Q. If a man has a large orchard, how much time will he have after the petals fall?

A. Not over a week to do good work.

Q. If one sprays in the fall for anthracnose is it necessary to spray in the spring.

A. Yes, I think so. That brings up a question that is not fully determined yet. The lime-sulphur when used in the spring is used entirely for the apple-scab. That is a question that I am not prepared to answer definitely at the present time.

Q. Is there any danger of affecting the fruit in spraying with poison? 
A. No appreciable danger. You would have such a small amount of poison-two pounds of arsenate which would represent less than that in 50 gallons of water. There is no danger whatever.

Q. What elevation would be prohibitory in attempting to raise apples?

A. I do not know. It depends upon the region. There are parts of the country where they raise apples at 4,000 or 5,000 feet elevation.

Q. Would that refer to the foothills of the Cascades?

A. I do not know. I would not want to say. Personally I am inclined to think it depends upon your soil conditions rather than upon the elevation.

Q. When is the best time to spray for the San Jose scale?

A. Two seasons of the year. One would be right after the leaves fall in the fall, and the other just before the buds start in the spring. Preferably the latter. The San Jose scale is hardly an orchard problem any more, it is so easily controlled. It cannot thrive under good orchard care.

Q. Did you say to spray for the apple scab before the apples were picked?

A. That is a debated question. The apple scab starts at two seasons of the year; one in the spring just about the time the apples are forming; and then after the dry season again in the fall; that is, when the fall rains begin. If we can control apple seab by spraying in the fall after the rains begin, it will also enntrol anthraenose. It is a serious question in the fall. Now the question comes up again. what will be the effect of spraying before the fruit is taken off? I will say that we sprayed 50 acres this fall of the best Spitzenbergs in the valley with no detrimental effects, as far as the apples were concerned, except they necessitated a little rubbing.

Q. How about the tent caterpillar? What do you do for them?

A. The best way to destroy them is to use the arsenical sprays; about two or three pounds of arsenate of lead to 50 gallons of water when the larvae are small.

Q. Would there be any virtue in destroying the leaves under the trees that are affected?

A. Yes, if one can plow them in and keep them there so as not to plow them up in the spring. That would be sufficient.

Q. Is there any virtue in harrowing the leaves in the spring so that they might dry up?

A. I do not know, but I do not believe so for this reason-that any ground that is in condition to grow apples will have moisture enough to germinate apple scab spores.

Q. If plowed under in the fall, how long should they remain in the spring?

A. Pretty well until the close of the rainy season. 


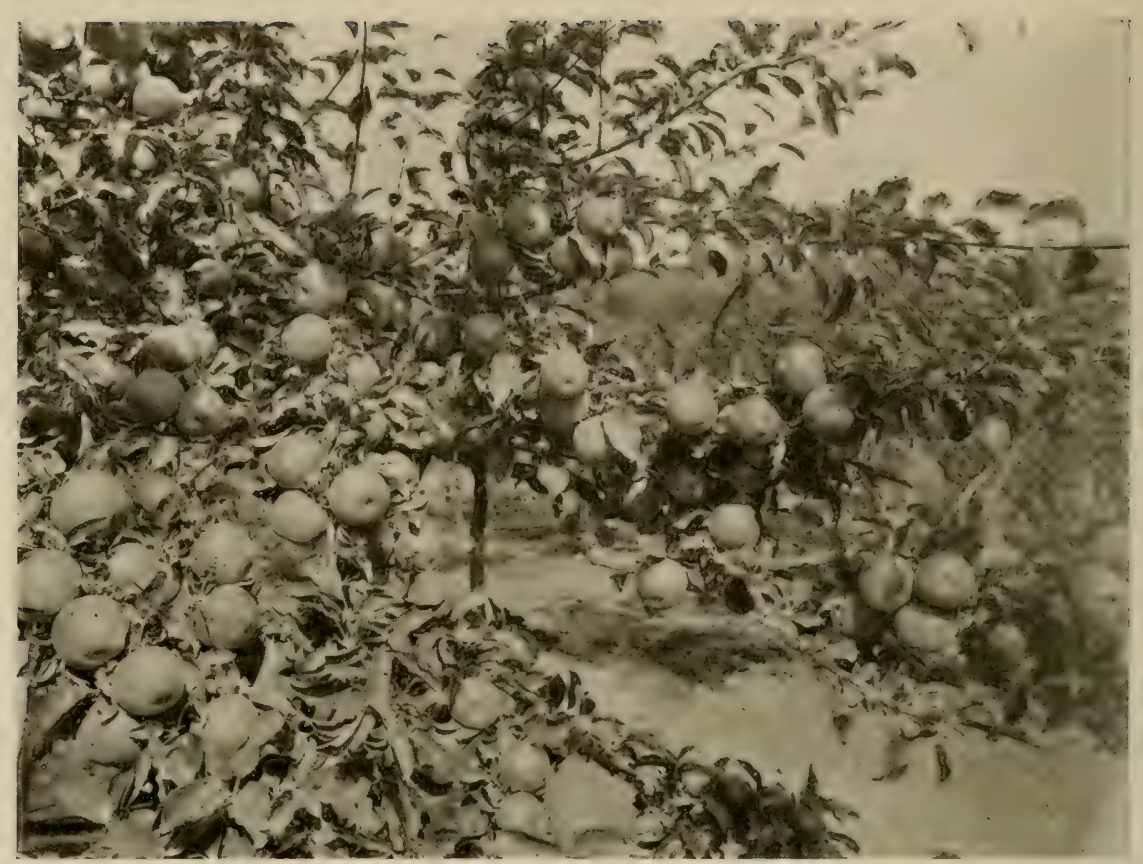

Branch of apples from The Dalles (Oregon) district.

\section{Apple Scab and Crown Gall}

Prof. H. S. Jackson, of the Oregon Agricultural College.

Н

PPLE seab is the most serious and most generally distributed fungous disease of the apple known, and in the Northwest is particularly severe in favorable seasons west of the Cascade mountains. The summer spore stage of this disease develops on both foliage and fruit. On the foliage the spots are at first mcre or less circular in outline, olive green or brown in color, becoming darker and irregular in shape as they become mature. The leaves are frequently more or less curled or wrinkled. When the spots are abundant, the leaves fall prematurely. Considerable defoliation may take place when infestation is abundant.

On the fruit the fungus produces more or less circular spots of a greenish-black color. The vegetative stage of the fungus develops under the cuticle of the apple fruit, finally rupturing it by the elongation of the threads which bear the spores. The ruptured cuticle may frequently be seen clinging as whitish membraneous shreds about the edge of recently developed spots. As the spots become older all trace of the fungus may become obliterated and the only evidence of the former spot is seen in a large or small rough russeted spot. Fre- 
quently the fruit is distorted when mature as the result of early scab infections. Where scab spots are abundant the fruit may become cracked. Scab in any degree of severity on the fruit renders it unsightly and unmarketable. The spores of the fungus are produced in the spots on leaves or fruit in great abundance and are disseminated by the wind spreading the disease to other leaves and fruit. One finds the scab spots first appearing in the spring on the under side of leaves on the lower branches. Spores produced in these spots are disseminated by the wind and serve to spread the disease to the young fruit and to other leaves. Several generations may thus occur during the season.

The development of the scab fungus is found to be very much influenced by weather conditions. Moisture on the surface of leaves and fruit is essential to the germination of the spores and the consequent infection of the plant. On this account seab is found to spread most rapidly in spring, early summer and late fall. The disease spreads little, if any, during the dry season. The Mycelium of the fungus present on the leaves which fall to the ground in the fall does not die. but develops in these leaves during the winter as a Saprophyte, and in the spring produces spores quite different from those borne in the spots on living leaves and fruit, both in the manner of formation and in the shape and size. The spores found in the spots on leaves and fruit are one-celled, rarely two-celled, and are borne on the ends of short threads, while the spores developed on the dead leaves in spring are always distinctly two-celled and are borne in little cylindrical sacs called asci. A considerable number of these spores or sacs are borne in a hollow more or less pear-shaped receptacle buried in the tissues of the leaf. These receptacles containing the asci, known as perithecia, project from the surface of the leaf when mature as little black elevations. These are barely visible to the naked eye. At maturity an opening appears in the projecting elevations. The asci elongate through this opening and the spores are ejected forcibly, and, wafted by currents of air, may be carried to the young leaves of the apple, where they germinate and produce the first seab spots. This spore stage of the fungus which develops on the fallen leaves is sometimes called the "sexual" or "perfect" stage. The stage which develops on the living leaves and frutit is called the conidial or "summer spore" stage. The sexual spores are disseminated about the time the blossoms open. So far as is known, all primary infection of the leaves and fruit in the spring takes place following the disseminations of the sexual spores. As with all fungous diseases of this nature, treatment must be preventive rather than curative. The method of treatment is dependent on the life history of the fungus causing the disease. Since 
the fungus winters over on the fallen leaves, it would be advisable to destroy all such leaves before blossoming time. It has frequently been recommended by pathologists to plow the orchard early before the trees blossom, so as to bury the leaves and thus reduce the primary infection. Theoretically, the best way to destroy the leaves would be to rake and burn them, but pathologists have hesitated to make this recommendation on the grounds of impracticability. I an informed by certain Ilood River growers that they would not consider it at all impractical under their conditions to rake and burn the leaves.

In any case the trees should be given at least three sprayings during the spring. The first application should be made as the blossom buds begin to separate in the cluster and show color' the second should he applied just after the petals fall, followed by a third application 10 days or two weeks later. Should the third application be followed by prolonged rains, a fourth may be found profitable. Formerly Bordeaux mixture was used almost entirely as a preventive of scab, but in certain sections of this country, notably under the climatic condition prevalent in the Northwest, the injury from russeting has been so severe as to make its use prohibitive. On this account lime-sulphur has largely supplanted Bordeaux as a remedy for apple and pear scab. The experience during the present season has shown that care must be exercised in the use of lime-sulphur during hot weather. Considerable injury resulted in the Hood River valley wherever the third spraying preceded very hot still weather. Under these conditions sun scald normally present in slight amount on unsprayed trees, was very much increased. A russeting similar to that produced by Bordeaux mixture was not uncommon. This is the first season that lime-sulphur has produced any serious injury to fruit when used in the proper strength. This injury, however, has not been general throughout the state. No serious injury has been reported from the Willamette valley.

The season's experience leaves many growers, particularly those of the Hood River, in doubt as to what spray to use. We eannot recommend the use of the Bordeaux mixture. Lime-sulphur still remains. the best remedy yet discovered for apple seab. On account of the experience of the past season, however, the grower must use his judgment about making the third application. In some seasons it would, without doubt, be perfectly safe to omit it, but in seasons favorable to. the development of scab its omission might prove disastrous.

On account of the fact that seab develops rapidly in the fall and new infections may appear on the fruit, we are ready to recommencl a fall spraying with summer strength lime-sulphur when the disease has not been held in control during the summer and there is considerable foliage infection, which, under favorable conditions, would be: 


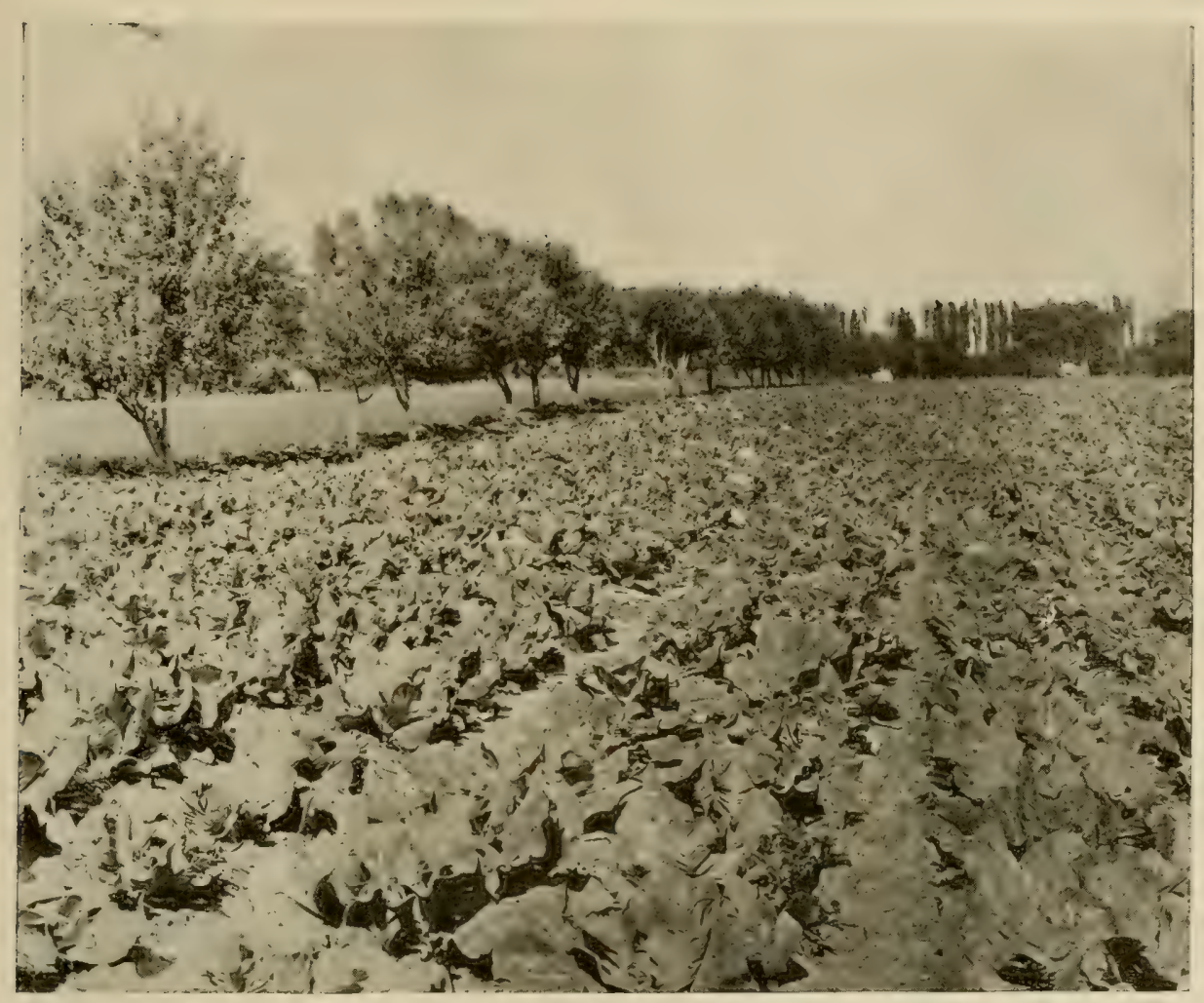

Truck gardening and apple growing in the Walla WValla Valley, Washington.

liable to spread to the fruit. The application should be made before the fruit is picked and before the fall rains begin. This applicatiou, while producing a slight deposit on the fruit, does not interfere with the uniform coloring of the fruit in the case of red apples. However, on account of the fact that a slight sediment is present, it is necessary to wipe the fruit. Do not use the Bordeaux mixture at this time. as it may collect in drops on the fruit and interfere with the miform coloxing. A very valid objection to this application, however, is the danger of linocking off the fruit during the spraying. and the fact that where props are used abundantly it is impossible to drive between rows with a spray rig.

In any case, it is advisable to spray in the fall as soon as possible after the fruit is picked. This application is necessary to protect the trees from anthracnose and will doubtless aid in the control of scab. Either the Bordeaux mixture or the lime-sulphur may be used in the winter strength. It is possible also that the dormant spray 
usually applied in the spring of the year may be of benefit in reducing scab by preventing the proper production of spores in the pustules of the dead leaves. On this account it is well to see that the ground as well as the tree is covered by spray.

It has been shown experimentally that scab may be satisfactorily controlled by the fall and early spring applications. These sprayings, together with the recommendations regarding burning or plowing under the leaves are supplementary methods of control. The regular spring sprayings on the foliage should never be omitted. It is important to note that lime-sulphur has now been successfully used in the state for four years, as a remedy for scab, and for three years the remedy has been used successfully in other parts of the country. The present season is the first in which any serious injury has resulted to the fruit and that having occurred only in the Hood River Valley and vicinity. While it is admitted that there is plenty of chance for further investigation, which will undoubtedly be continued, it is evident that lime-sulphur remains the best remedy so far discovered.

\section{Crown Gall and Hairy Root.}

There is, perhaps, no disease of the apple and other fruit trees concerning which there has been as much discussion in recent years among plant pathologists, nurserymen and orchardists as the crown gall and hairy root. The disease has long been known to attack nursery stock in one form or another, and orchard trees of all sorts as well as many of the small fruits. Recent investigations of this trouble have shown that the disease as it occurs on its various host plants is in many cases identical as to cause, and in nearly all cases evidently closely related. The general character and virulence of the disease are so variable that it is confusing to discuss it in all its relations at the same time, so it has seemed best tonight to confine the remarks to the disease as it occurs upon the apple. The apple was selected for discussion because it was felt that a large proportion of the audience was, or ought to be, particularly interested in this subject.

Various names have been applied to this disease among which may be mentioned, besides the names previously given, the following: "Root knot," "root gall," "woolly knot," "tumors," "trunk kernel," ete. Crown gall and hairy root are best known as occurring on nursery stock or young trees. Several forms of the disease are known, including the following: Soft form of crown gall, hard form of crown gall, simple form of hairy root, woolly knot form of hairy root, aerial form of hairy root. The soft form of crown gall is found on seedlings, grafted and budded trees, and consists first of a soft, succulent 
growth of callous-like tissue, which is white in color on the surface. As the galls mature the surface becomes dark brown in color or almost black and the tissues often become quite hard, due to the formation of woody tissues. The surface is wrinkled and convoluted, due to unequal growth. A bark is not formed and the galls usually decay at the end of the season's growth.

The hard form of crown gall is found on older trees in the nursery and orchard. At first they are similar to the soft galls, but soon become woody and develop bark. They persist and continue to grow slowly from year to year. The color of the surface of mature galls is similar to healthy bark. The simple form of hairy root is most common on seedligs, but oceur occasionally on grafted and budied trees. In this form numerous roots are found growing at right angles to the surface of the tap root or stem. They may occur scattered or in tufts. These roots differ from normal fibrous roots in being more succulent or of greater diameter. When dry they become hair-like in appearance. The woolly knot form is found on older seedlings or on grafted and budded trees. This form somewhat resembles a case of hard crown gall which had developed an abundance of the succulent roots described above from its surface.

The aerial form of hairy root, often called "stem tumors," or locally "trunk kernel," develops on branches and trunks of trees most commonly in the orchard. At first they appear as smooth swellings, which are rounded, but often irregular in outline. They later develop on the inside an abundance of adventitious roots which break through the bark, giving it a warty appearance. These roots do not develop further than the surface of the tree, but morphologically are very similar to the woolly knot form of hairy root, and if the branches are eut off and placed in moist soil or sand will develop into typical cases of woolly knot.

Recent investigations of the plant pathologists of the Department of Agriculture have shown that both the crown gall and hairy root forms of the disease are due to bacteria which have been isolated, grown in pure culture and the typical disease produced by inoculation. It has not yet been shown that the bacteria from both forms are the same, or that one form may be produced by inoculating with the germ of the other. The several forms of the disease which have been described, however, are so nearly related morphologically that it is not improbable that all are caused by the same organism and are merely forms of the same disease. At least, they may be so considered for practical purposes.

Crown gall and hairy root develop on the trees in the nursery and are the most serious diseases with which the nurseryman has to con- 
teud. Many states have enacted laws prohibiting nurserymen from selling infected stock, and since the diseases are everywhere present in nurseries, these laws, where enforced, have caused a great loss to the nurserymen. A great deal of valne might be learned from a detailed discussion of the disease as it occurs in the nursery, but sufficient time is not available, and, since this is not primarily an audience of nurserymen, I will discuss only the features which I believe will be of interest to the orchardist.

Crown gall and hairy root in all its forms develops, so far as is known, only at wounds. Throughout all seedling nurseries in the United States crown gall was found to be present in one-half per cent of all trees and hairy root on one per cent. Since these seedlings are either used for piece or whole root grafts, or as stock in which to practice budding, it is seen that unless the nurseryman is careful to use only healthy seedlings many grafted and budded trees are infested. In root-grafted trees wounds are made at the lower end of the scion piece and at the upper and lower ends of the root piece; since all forms may develop at wounds we found crown gall or hairy root developing at these points-that is, at the great union either on the scion or root piece and at the end of the root. Ninety per cent of the galls formed in this way are found to develop from the lower end of the scion piece at the graft union. On budded trees crown gall or hairy root develops at the root tip where the tap root has been cut off and at the wound made in inserting the bud. The hairy root forms are more abundant than the gall forms on the budded trees. The disease on the whole develops more abundantly on root-grafted trees than on the budded trees.

Th crown gall forms are found to develop most abundantly on heavy soils while the hairy root forms may be more abundant on light soils. There has been a great difference of opinion regarding the amount of damage resulting in orchard from planting diseased trees. There have been many reports of great losses to orchard trees due to the action of crown gall and hairy root, many writers claiming that diseased trees never come into profitable bearing. It is evident that much confusion has resulted from the fact that the disease is very serious in the orchard on some fruits and writers have assumed that the same was true of the apple. It is also evident that other root troubles, notably root rot, has been confused with erown gall. Careful investigations have shown that much less injury has resulted in the orchard from planting diseased trees than was supposed. I mention these points not to encourage nurserymen to sell diseased trees, nor the grower to plant them, but to correct a prevalent idea and, perhaps, to encourage those who have already planted diseased trees. 
It is known, however, that some loss does oecur on the apple in the orchard when diseased trees are planted. I know of several cases where trees were evidently stunted by the growth of hairy root or crown gall on the roots. It has also been shown that trees affected with crown gall are more liable to die the first year or two after being set in the orchard than healthy trees. The orehardist is urged to plant only the healthiest trees obtainable. The initial cost of planting is so small that it does not pay to take risks. If a tree becomes diseased in an orchard during the first few years and the growth of the tree is hindered, then it is best to replant with a healthy tree. If old trees in an orchard are found infested and yet in good growing condition and bearing good crops, it is best to let them alone and not attempt to cut out the galls. If the trees are seriously affected by the growth of the galls or hairy root, then the grower may try cutting out the galls, disinfecting the surface and painting the wounds, but it is usually not found to be successful.

If for any reason it should be thought necessary to plant infested trees, then do not attempt to cut out the galls before planting. It has been found that the young trees are most seriously injured by the wounds formed in eutting out than by the galls. Stock should be earefully inspected to see that the nurseryman has not cut off the galls before shipment and any trees showing evidence of such treatment should be discarded. Fruit inspectors should use eare in inspecting stock, and make sure that all trees condemned are really affected with crown gall or hairy root. All warts and pimples are not necessarily crown gall and all fibrous roots are not necessarily hairy roots. There is little or no danger of diseased trees in a shipment of nursery stock causing infection in healthy stock, so there are no grounds for conlemning a whole shipment because a few trees are infected. There is little or no danger of the disease spreading seriously in the orchard.

Considerable attention has recently been given to investigations of methods whereby the nurserymen may reduce the prevalence of the disease in the nursery, and it is found that by practicing certain precautions and special methods of nursery practice the trouble may be very materially reduced. Nurserymen are urged to inform themselves of these results, which may be found discussed in Bulletin No. 186 of the Burean of Plant Industry, U. S. Department of Agriculture, Washington, D. C.

\section{Questions and Answers.}

Q. When a tree is diseased with crown gall, and that tree is taken out and a healthy tree planted, is the healthy tree liable to be infested? 
A. No, not in the case of the apple. I wish to point out that my remarks pertain to the apple alone. If it were a peach tree, I would say that it would be likely to be infested.

Q. What protection can the nurserymen take to prevent this?

A. He can be careful about using only healthy seedlings. It is found that throughout all seedling nurseries in all parts of the United States there is a normal development of ercwn gall. It is generally true that one-half of one per cent of seedlings are affected with the crown-gall form, and one per cent with the hairy-root form. That is one method. I have stated that disease occurs only at wounds, so any reduction in the amount of wounds reduces the effect upon the trees in the form of crown gall in the nursery. It is also found that disease is more prevalent upon root-grafted trees than upon budded, for the reason that less serious wounds are made. It is found that the disease develops at the graft union, when it is not well made.

Q. Are irrigated trees more subject to this disease?

A. Not so far as we know.

Q. Are seedlings grown in France and other countries as susceptible as those grown in this country?

A. The question has often heen raised as to whether the French stock seedlings grown in France were more or less susceptible in other comntries. It is found that there is a slight difference in favor of the American grown seedlings as far as crown gall is concerned. 







\section{Poultry in an Apple Orchard}

By Professor H. L. Blanchard, of the Washington State Experiment Station, Puyallup, Washington.

(1)

HAT I will talk about tonight is logically along lines connecting poultry culture with orcharding. Both are profitable lines of farming if intelligently managed. I doubt very much if scientific farming (and orcharding is farming) can be conducted along any line in these times without poultry.

I have been interested in poultry culture for something like twentytwo or twenty-three years, and I have been studying and observing during these years the work of those who were interested in the same lines of investigation. About 12 years ago I had occasion to ascertain as nearly as possible the amount of money that the State of Washington was sending abroad for poultry and poultry products, and learned that we were sending out $\$ 300,000$ annually. The farmers of the Middle West were getting the money that our own farmers should have had. In a more recent investigation I learned that the State of Washington paid out more than $\$ t, 000,000$ for poultry and poultry products. There is a constant increase from year to year. We have many poultry organizations throughout our state; practically every county in the state has.a poultry organization, and, notwithstanding that, and the interest that is being taken in the poultry business, the demand is far oustripping the supply year by year.

\section{Too Much Money Goes East.}

Admitting that beyond any question poultry culture can be profitahly carried on in the Northwest. is it not a great mistake to allow so much money to go out of our own country for poultry and poultry products? In Oregon the conditions are the same. Large sums of money for poultry and poultry products which your producing class ought to have are heing sent to Eastern producers. Why is this being done? Simply because the impression prevails that there is not much money in poultry; that feed is too high; that there is something the natter with this country, notwithstanding the fact that eggs are 30 , 40,50 and 60 cents per dozen at different seasons of the year. That is two or three times as much as eggs ought to cost. Notwithstanding that fact, we are told that there is not much in the business-nothing 
in poultry. Some people will take ponltry and make their hens net them $\$ 3$ and $\$ 4$ a year, after paying their feed bill. That is being done in a great many instances throughout the West. If one person can do that, another can. Poultry culture is not so scientific that the average person cannot undertake it without a fair hope of success.

My observation teaches me that the orchardist who has a flock of poultry roaming through his orchard from one year's end to the other has better apples than the man who has no poultry running in his orchard. Everything points to the fact that poultry are profitable, even if they do not lay at all. We have rhubarb growers over in our country who keep cows. and they say that they can well afford to keep them even if they do not get a drop of milk. just for the fertilizing elements available to use in the rhubarb patches.

\section{Poultry Did the Fertilizing.}

Not long ago I was in a community in Washington where orcharding is extensively engaged in. I went up on an elevation on one side of the man's farm and looked down upon a patch of his orchard that looked green and healthy, whereas the rest of the orchard was wilted, which showed that something was the matter. I asked the man how it eame to be that way. It was in the dry season and the orchard was in a dry locality. Most of the crops there had been affected by the dry weather. He said: "You see the foliage is still green and growing. There is where my poultry pens are." IIe had poultry in his orchard covering a certain area. The poultry were working, cultivating and fertilizing, and kept it in perfect growing condition in spite of the dry weather. The rest of the orchard had no poultry. There is no question about the fact that poultry are of great service in the way of cultivating and maintaining the dust mulch in fruit orchards. In the valley where I live in Puyallup they are engaged quite extensively in small fruits. I believe we have one of the largest and strongest small fruit associations in the country. The berry growers are becoming very much interested in poultry. The fact is. they do not pretend to do very much with berries unless they introduce poultry. Poultry keep the weeds down and keep a dust mulch, and save a great deal of labor. Many of these men have told me that it would pay them to keep poultry even if they did not receive any eggs.

It is not necessary to keep poultry in an orchard at a loss. There are a few things essential to egg production. In the first place one must have the right kind of a hen. She must be healthy. You and I can do a good day's work well even if we have not been feeling well 


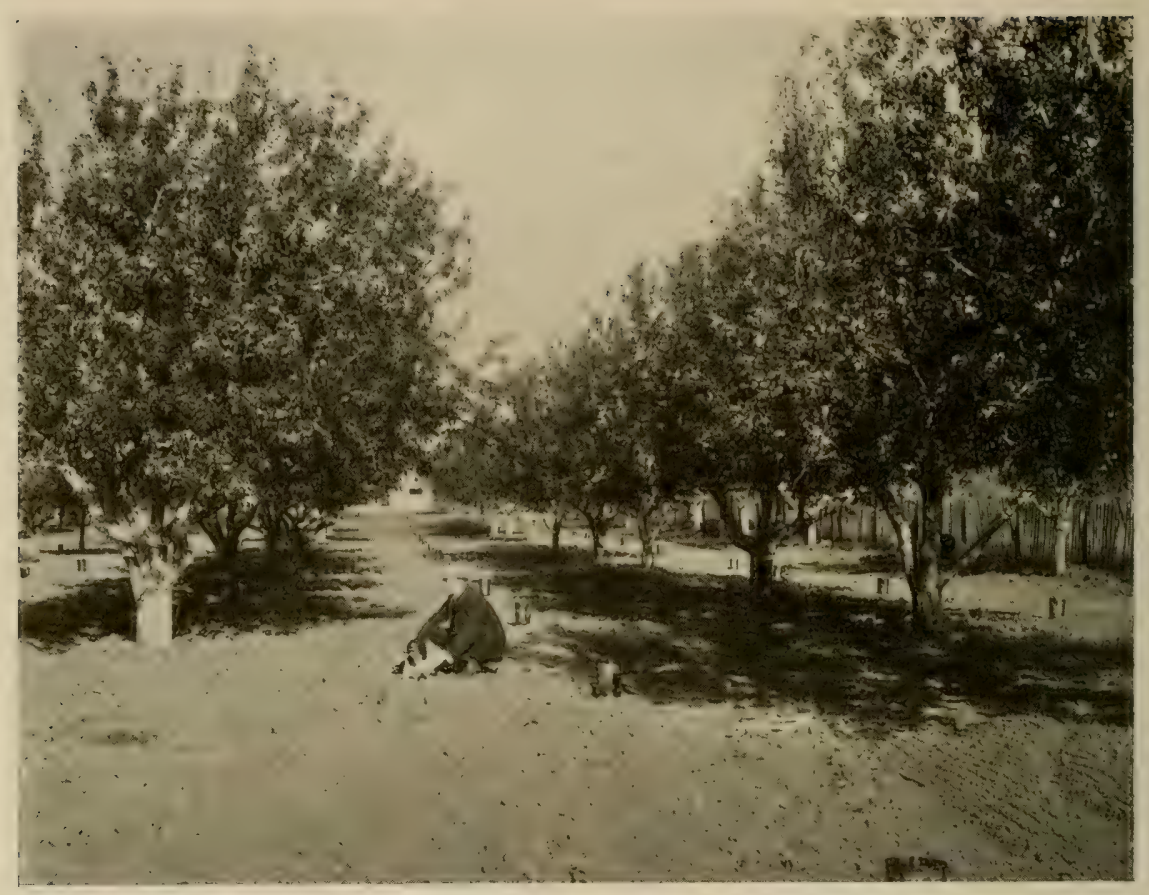

Preparing an orchard in the Rogue River Valley for smudging.

for a few days, but when one sees a hen moping around she is not going to lay any eggs that day. She will barely eat enough to maintain her existence, say nothing about eating enough to make eggs when in that condition. It is surprising to me, as I pass through the country. to see intelligent people who expect results from poultry when they treat them the way many do. These people are the very ones to proclaim that poultry does not pay as a rule. One should be careful in the handling of his poultry, the same as in the handling of his children. He must be as careful of the health of his poultry as he is of the health of the members of his family. To do that he should first give his attention to the matter of a sanitary coop for his poultry.

\section{A Sanitary Coop.}

What is a sanitary coop for chickens? A coop that is sanitary for you and me. How many of us would be willing for the members of our family to room there, sleep there and live there? Not many. A great many people visit our experiment station. We have been there about a year and a half. The first work in this poultry plant is to teach poul- 


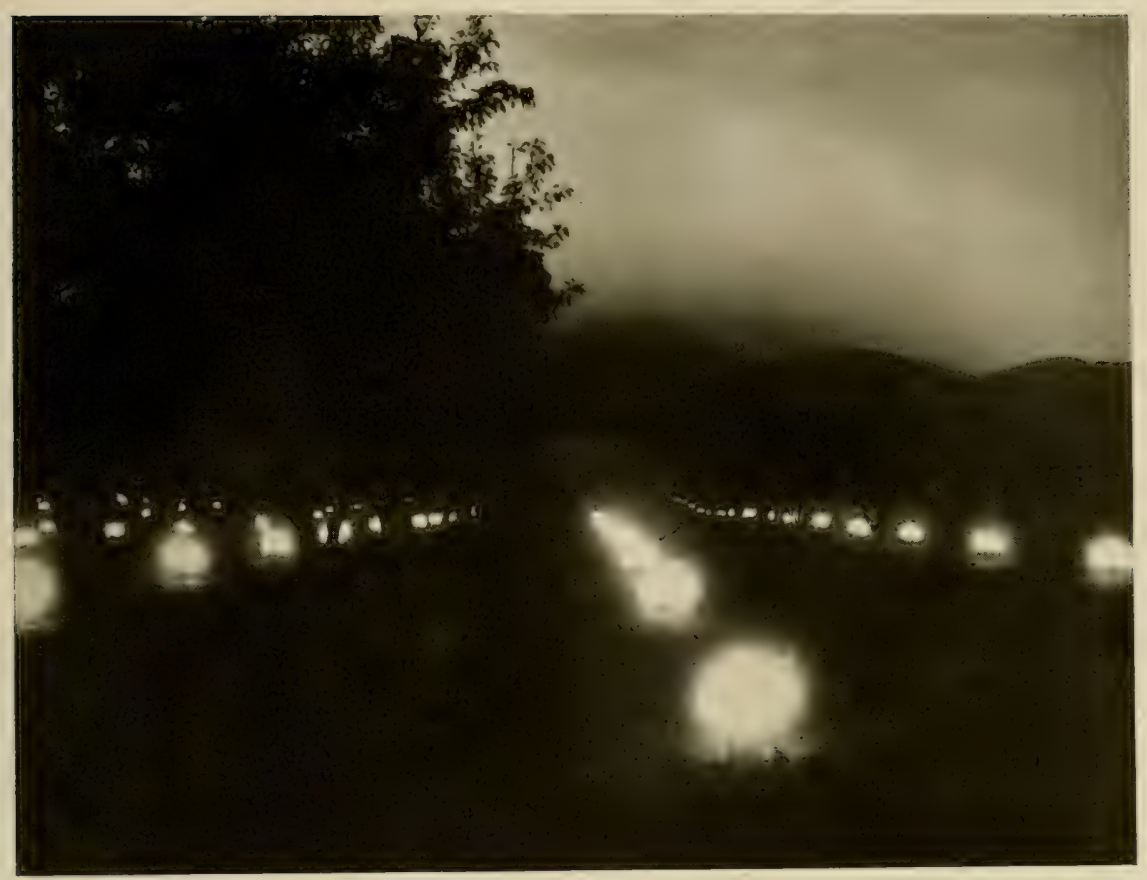

Night scene in an orchard in the Lewiston, Idaho, district. Smudge pots in operation.

try to people from a practical standpoint; teach them how to make a living; how to make money from chickens. We went to work about this matter just as we would if we were on our farms. I have a farm in Washington and have had a poultry plant for 20 years. I have Jersey cattle and poultry, and each line of farming receives careful attention just as though there was but one line. One should treat poultry as an adjunct of his orehard work, and he will find it one of the most profitable things he can possibly do. We tried to see just what we could do at the station last year with poultry, starting with 200 hens. We constructed a house that accommodated them nicely, although the location was anything but desirable, being in a shot clay ground; it was a cold, muddy, sticky, bad place for poultry or any other stock six months in the year. We constructed a house to meet our conditions. I advised our college against putting in a poultry plant there after making three visits to the place. I regarded the conditions so abominable that I would not be guilty of advising a poultry plant being built there. They got one adverse report after another, then they reminded me that the people should know that an experiment station should be careful in selecting a site upon which to construct its business in poultry, and know what were favorable 
and unfavorable sites for the business, and that it was just as important to know this as anything else. We just had to make a success of it, and we built our house, met the conditions. This experiment has taught me beyond any question that it is not at all difficult to meet most any adverse condition. Such conditions in poultry work can be met better and easier than in any other line of farming.

\section{Big Profit the First Year.}

Starting in with 250 pullets-- the first pullet year-I turned into our state treasury over $\$ 2200$. It took a building 130 feet long by 12 feet wide to house these pullets. That is what we call a double lecker. It would be folly for these pullets to be allowed to run outside under the conditions that existed there. We would not have gotten an egg all winter for six or seven months in the year. People laughed at and ridienled us for putting in a poultry plant there, but some of the same people are putting in a small plant on their farms. I do not mean that these pullets laid eggs that brought $\$ 2200$. The net profit from these pullets was just $\$ 8.10$ each, but we did the business. That is for the eggs they laid, figuring eggs at the average price. To get our start we bought young chickens or hatched out the most of them. In all we had 1017 chicks, from which we selected these 250 pullets and put the others on the market, then when these pullets came along in the following spring we hatched more chicks at the station. We conducted our experiment along business lines.

We selected these 250 pullets and put them into the house when they were $31 / 2$ months of age. When they were from 4 to $5 \frac{1}{2}$ months old they began to lay. It does not take long to get returns from a flock of pullets, but it takes one a good many years to get a revenue from his orchard. One can get something from his poultry while his orchard is growing. When the season came around we decided to sell day-old chicks. We hatched out between 9000 and 10,000 and sold some broilers and some chickens. The total proceeds from the sales of this poultry brought us in a little over $\$ 2200$ for the year's work. It is a legitimate, straight business that any one who wants to interest himself in poultry can adopt and follow.

\section{Hens Grubstaked Him.}

I was talking to some people in the central part of the state not long ago, where they were setting out young orchards by the thousand trees. They were wondering what they were going to do while their 
trees were growing and becoming productive. While we were talking that evening, some one in the audience gave me his experience. $\mathrm{He}$ had gotten to that point in the growing of his orchard where his eredit was gone. He could not buy flour or sugar at a store. He got word some way that there was a flock of chickens for sale in the neighborhood. He bought them and gave them good eare. IIis eredit was restored and he has become an independent man. He said it surely would have been impossible for him to have grown his orehard and owned it until it became productive, had it not been for the poultry. If one takes up poultry with his orchard work, he should do it right. Have a system. Some people like the fancy side of poultry. I like it, but have never followed it. I attend the shows, but do not show birds. I attempt to raise and sell show birds, but I do not sell them because they are show birds, but because they are birds that have been developed into extra good layers. They are utility stock, and that is the line along which I have been working for 20 years. Profitable poultry, like a profitable dairy, must be developed. Unless one is willing to become a student of his work and is willing to make a study of his business, he wants to let farming alone. It is just as sensible for a husiness man to trust all his business to somebody else and not study it, not to keep himself posted and neglect his business, as it would be for farmer's to think they can farm and make money or make a living with indifferent attention. Diversified farming is the most profitable throughout the Northwest-say west of the Cascade AIountains. This is fast developing into a country of homes, small farms, and to make a living on a small farm one must practice diversified farming.

\section{Soil Will Run Down.}

The orchardist is perhaps an exception. We hear of fabulous returns from one, two, three and five-acre orchards. It is possible that a man can make a living with fruit without anything else, but if one undertakes this he will find that his orchard will be productive for a while, but after a few years it will become diseased and grow worse every year.

About a year ago the State Horticulturist was invited to canvass the neighborhood of Vancouver. There had been a great deal of trouble about the prune orchards there. The orehardists were not getting the usual quality of prunes. Their trees were becoming diseased, and they did not know what the matter was. They wanted the horticulturist to study conditions before the meeting in order to advise them intelligently, and he did so. Had I been a prune farmer near Vancourer and received the lecture that this horticulturist gave 
these people I should have felt like going out of business, notwithstanding the fact that just a few years before this they were growing such an excellent quality of prunes and had such enormous crops. What was the matter? The real thing that brought on this trouble more than all other things combined was a depleted fertility in the soil. When their trees were from one-third to one-half grown they bore luscious fruit and were heavily laden, but at the present time the branches of the trees were interlocked so a team could hardly get through them. The sun could hardly reach the ground because of the close association of the trees, and the soil had become practically exhausted of its fertility. I will venture to say that had those people carried flocks of poultry in their orchards they would never had to call in the lecturer of the State Horticultural Society. I know from my own experience, as I have had an orchard for over 20 years. The poultry have been running through half of it all that time, and have strolled cver the other half, but have never been confined in it. A person can go there any day and pick out the half where the poultry were confined. One can pick out the apples from the trees where the poultry is running.

\section{Poultry is Indispensible.}

Poultry is indispensible to an orchard. Orchardists are very apt to neglect their soil, both in regard to cultivation and fertilization. A horticulturist was delivering a lecture in a demonstration train in Washington. He was talking to an audience about the size of this one, and was explaining to them how it was that this was the driest year ever experienced in the college orchard, still the finest fruit had been produced. There were no poultry in the orehard, either. He said that during the summer the orchard had been cultivated 17 times. Then he said: "How many of you have cultivated your orchard 17 times this year?" No one had anything to say. Then he asked: "How many of you have eultivated your orchard once this year?" There was not one hand raised. "Why," he said, "don't you ever cultivate your orchards over here in Washington?" One man said, "Yes, we cultivate them once in five years."

This horticulturist is of the opinion that just as fine and just as high-priced apples can be produced in Western Washington and Oregon as in the Wenatchee and Hood River Valleys. He was asked how he was going to do it. He said: "Do it just the way the people do it there It eannot be done in any other way." He said not to attempt to compete with the people of the interior in growing red apples, because if we did we would get beaten a little, but said we would have the 
advantage of being able to grow apples that they cannot, particularly in growing the yellow apple. Grimes' Golden was recommended as one of the best. Since this horticulturist delivered his lecture our Grange organization and other fruit growers' associations have almost unanimously adopted with two or three other apples the Grimes' Golden. The horticulturist recommended four varieties, but Grimes' Golden is the leader.

\section{Avoid Too Many Varieties.}

The idea of our people is that the different communities work together and agree as to the varieties they should grow as a community, and go in for these varieties. I think it a wise move. They have taken a great deal of interest in the fact that these things can be done, and the apple business of Western Washington will be revolutionized within a very few years. If that policy will work there, it will work here.

If one is to be successful in his orchard work he must not neglect the fertility of the soil, because that means serious trouble sooner or later. Keeping poultry is one of the cheapest ways to do this. If one has an orchard and will keep 25 hens on a half acre he will be astonished inside of two or three years at the condition and quality of his fruit and the condition of the trees. A very few chickens running in an orchard are valuable. They will keep down the weeds and pests. A great many pests live on the ground and the chickens destroy them. The continual stirring of the soil during the dry season by poultry is a valuable thing, and the keeping of poultry in an orchard is a laborsaving institution.

In regard to the sanitary coop. When you see your neighbor making a success of it you will see the difference and begin to keep one yourself. There is a right and a wrong way to do this. I mentioned a while ago that the poultry must be healthy. A sanitary coop in this country is a coop with an open front facing the south, when it is possible to make it so. Sometimes it seems impossible. When it faces the south it gets the sun into it. The old-fashioned coop used to be stuck away somewhere over the pigpen or under the cowshed or in the horsebarn or the woodshed. All of these places have been utilized as chicken coops. In these coops it is dark even at midday when the sun is shining. They are filthy and not at all inviting, and a person who undertakes to keep poultry under these conditions cannot expect to derive very much profit from them. The poultry would not have life enough to go around and scratch among the berry bushes and fruit trees. They live just because they have to. 


\section{Size of the Henhouse.}

For 30 hens a house should be about 15 by 20 feet in size, if one builds a single story house. If you build a double-story house it should be 12 by 15 feet. Our experience leads us to believe that the doubledecker house of Western Washington is the best that ean be built. I have tried this for the last 15 years on my farm, and my poultry have not had a case of roup nor any contagious disease. The only thing that kills our hens is that they lay so many eggs.

Poultry should have plenty of air. Make a house open without a draft in it. People believe that this country demands a tight house. An open house is indispensable here. This is my experience. Take a damp climate as we have here, and if chickens are housed up tight in a house with glass windows, conditions are anything but sanitary for seven or eight months in the year. It is all unnecessary. Have a room 15 feet one way and 12 feet deep. Let it face the south. Put two open windows five feet square in the front of the building, and tack on the outside two or three-inch poultry netting. On the inside put a muslin curtain on a roller just the way we do in our dwellings, and when storms come draw the curtain. The storm will be kept out and there is no draft, providing the three remaining walls of the conp are absolutely tight. They cannot be too tight. In the ordinary chicken-house the boards are nailed on when wet and green, and after a while one can see a man as he walks back of the building. The chickens gets into a draught and will have the roup in a short time. Make the back of the wall as tight as possible. We use ordinary ship-lap. First put on building paper next to the studding, then side up over that. That makes a tight wall. We do not build our houses for warmth. All that poultry need is shelter. It never gets so cold here that poultry will suffer. The open-front houses are warmer than the tight ones. I am often asked by people who visit our houses what we do when the cold snaps come on. Our chickens have large combs and wattles and we have never had a frosted comb on our farm. We have Minoreas and gave this a fair trial. Two years ago this winter we had a flock of Minoreas in a building on one side and another flock on the other side. One side of the building was open and the other side tight. The result was three or four days after a cold snap the Minorcas in the tight room died. In the room provided with the open front and just the muslin curtain there was not a frosted comb nor a frosted wattle. By actual demonstration the muslin-curtained house was proven to be the warmer. 




Branch of apples from The Dalles (Oregon), district.

\section{Open-front House.}

At Cornell University a year ago they found this condition by use of a thermometer. The thermometer in the room with the openfront indicated a higher temperature than in the room closed tight with glass windows. Anyone can test this point without the use of a thermometer. Go into one of the tight houses on a cold morning where your chickens have been on the roost over night, then step into a room where there is open front. Every time you will find that the room 
with the open front is warmer. If you want stock that is healthy and will bring returns, build a chicken house without glass windows. In an open-front house with a basement you have summer conditions as near as possible for poultry the year around. We haul in some sand for the floor before we put up our building, then put in our posts. We plan an earth floor for the basement; the floor above is of ordinary flooring, the cheapest we can get. Our poultry do not go out into the water at all. In the basement they wallow in the dust, dirt and sand regardless of what the weather is outside, and it does not affect their laying at all. In addition to this, if we want to keep our poultry in a good, healthy condition we must see that they have exercise. There is a great deal said about hopper feeding, that is, to keep your feed before the chickens all the time. This is a mistake. Chickens should get exercise by scratching. A man in our neighborhood who has a berry orchard scatters the feed along among the canes of the berry bushes, and the chickens work for the grain. Another man who has no berry bushes hauls some coarse gravel and spreads it out to six inches deep and the chicks scratch for it and get their exercise, another man who uses straw keeps the floor covered from four to six inches deep and lets the chicks scratch for grain.

\section{Virility of Eggs.}

We use a good many incubators. We took off 58 hatches and obesrved that there was a very low fertility and wondered what the matter was. This year we have about 30 pens of poultry and every egg as it is gathered is numbered so we will know where to trace it. When putting these eggs into a machine we came to some that tested clear, and we knew right where they came from. Then we investigated and saw how to account for it. One time last year we found that practically all the eggs that tested clear came from one pen. I made an investigation and found that that pen happened to be the one in which we were carrying on another experiment without any scratching material for our poultry. We were hopper feeding, not thinking for the time of the effect it might have upon these eggs that we intended to use for incubation. To carry the test a little further in that pen we changed to seratching material, and inside of 20 days the test ran from 43 to 97 per cent of fertile eggs. That shows what effect exercise has upon the fertility of eggs. See that your poultry get their required exercise. 


\section{Balanced Ration.}

Poultry should be fed a balanced ration. We generally let the chickens balance their own rations. They are peculiar in that respect. Put a flock of chickens into a granary where there are four or five varieties of grain and none of them will get sick. A hen will eat some corn, some barley, some oats and wheat. She balances her own ration. If one would be particular in balancing the rations of his animals, and even for himself, there would be much less sickness in the world. I am a great believer in a balanced ration all along the line. I believe chickens require a balanced ration just the same as I believe our fruit trees require a balanced fertilization. Unless they get it they will have disease; they will be weak and lack vitality. Give them corn, oats, wheat and other grain that make a variety.

I was in British Columbia a few years ago. There was an institute being held at a town there. It was at the four corners, and the merchant there, a shrewd business man, evidently doing well in his business, happened to be delegated to entertain me. He said:

"I have a bone to pick with you."

I said: "All right; let's have it."

He said: "Well, my chickens don't lay any eggs."

I said: "I suppose I am to blame for it?"

"Well," he said, "to a certain extent."

"How do you figure that out?"

"I read something you said about feeding chickens and I am feeding mine according to your directions and not getting an egg."

"Where are your chickens?"

\section{Variety of Feed.}

He said he was going to feed them then, so I went out with him. He had something like 300 in a room 20 feet square. There was no windows in the house at all. There was a door for the chicks to go out and in, but it was dark inside. In front of this house was a shed about the same size. I tried to diagnose his case. I looked inside the house. It was furnished with the old-fashioned manner of fixed perches, commencing way down and ending way up, all on a slant like a stairway. The poultry would all fight for the upper perch, and I am sure I am not far off when I say that the house had not been cleaned out for three years. I watched him feed his chickens. He took an ordinary scoop and scooped out oats from a barrel and just literally covered the ground, which was entirely free from seratching material. The chicks picked up a little, then tried to see if they could 
not find something else; they did not seem to be ravenously hungry. There was not a drop of water anywhere.

Finally we brought up at the store. I said: "Now I will have something to say to you. I have got a bone to pick with you. I thought you followed the directions that I gave."

"Yes, I did."

"How do you make that out? What were those directions?"

"You said feed the chickens corn, wheat and oats; give them a variety."

"Yes, that is right. I would like to see you do it."

"Well, when that barrel of oats is gone I throw them some wheat."

Never attempt to feed wheat, corn or oats straight. Mix the different grains and put them in the litter. Keep some dry bran in a hopper, some beef seraps, shells and ground boue. If one has a dairy, milk can be used as a substitute for beef seraps. By keeping a variety hefore the fowls they will lay more eggs than if they are fed oats one month, wheat another and corn another. Do not forget that. The cheapest food that one can buy for his chickens is the one kind that will make them produce eggs. One wants eggs at the right season of the year to make money out of poultry, when they will hring a good price, and there is no reason why one should not have them at that time in this country.

\section{System in the Work.}

To do that one must adopt a system. How few people have a system in their poultry work? They say they ean hatch chickens early; but what is early? There is just as much difference in this as in the man's idea about mixing the grain. At the experiment station I find that people are getting a little wiser along this line of work. They all want early chicks. One correspondent writes in and wants chickens between the first and middle of May. Another thinks an early chicken means in February. One must have early chickens to get fall and winter layers. Chickens hatched in February might do worse than those hatched in May. We find that April hatched pullets of the Leghorn hreed will hegin laying in Septemebr and they will lay continuously if properly housed and cared for, until molting season the next year. We have a flock of pullets at the station of the White Leghorn variety that were hatehed on the 6th day of November last year. The first pullet laid her first egg on the 20th day of Jume. There were 83 pullets and they were practically all laying by the time they were five months of age. At that age we culled out 23 pullets. That left us 60 that were laying by the time they were five months old. 
The 60 pullets before they were nine months of age laid an average of $42 \mathrm{eggs}$ each. At the price of eggs at the time these were laid they would pay for their feed bill up to the time they were a year and a half old. This flock of pullets laid until the last days of October, then they were molting for about two months. They have since got to laying in good shape and the eggs from the first of January to the first of No. vember next will be our profit from that flock of pullets. This is an instance which simply required a system. These pullets were from a flock that had been developed for their laying qualities. When we use eggs this year for our incubators the culled pullets' eggs will not be used at all. We will only select eggs from birds that laid by the time they were five months of age. Practically all birds that lay at that age are well matured. They are the largest and best appearing birds in every way.

I am often asked how to select these pullets. That should be done when they are five months old. Do not wait until they are six months. We did not get an egg for six weeks from the 23 pullets we culled. We do not use the trap nest. By mingling with the poultry one will become acquainted with his flocks, and it is not a difficult thing to select culls at the age of five months.

\section{Questions and Answers.}

Q. At what age do these pullets become unprofitable as layers?

A. Under our system we do not attempt to carry any hens over beyond their pullet year, except those we desire to use in the breeding pens. When a pullet that is hatehd in April is 18 months of age sne will have laid something like 12 or 13 months, whereas the pullet or the hen that is carried through the molting period will lay only eight or nine months. To do her best she cannot lay to exceed that, so it is more profitable to do business with pullets. When possible, we advise the use of the two-year-old hen in a breeding pen. Do not make the mistake of using immature birds in the breeding pen.

\section{Renewing the Stock.}

\section{Q. What do you do with these 18-months-old birds?}

A. Dispose of all that we do not want for the market, and have a flock of pullets on hand to take their place, that have been hatched at a time so that when these enter the molt the new flock will be right on hand to take their place, so as to get a continuous supply of eggs. Do not undertake to hatch the Plymouth Rock, or the Rhode Island Red, or the Orpington in April and expect to accomplish that thing, 
because it cannot be done. If one is doing business with any of these breeds belonging to the American class, he should do his hatching at an earlier period, say for instance, not later than the first of April. We prefer from the middle of February to the middle of March for these large breeds, and the objection in years gone by, the difficulties in getting chickens hatched at that time because the hens would not become broody, is entirely overcome by the use of incubators. $\mathrm{Mr}$ business differs a little from the fancier. I am paid a salary for something the fancier is not doing, consequently I am brought face to face with the fancier now and then. I was addressing an audience about the size of this at a banquet in a town where there was a good show. An Eastern judge complimented the birds very highly. He said he had judged all over the United States and that it was rarely that he had judged a show that compared with this one; he was greatly surprised to find such high quality stock in the Northwest. There was one speaker after another. I had had a little quarrel with this association before this. I am a member and we have our meetings and of course do not agree on everything. I was quite surprised to receive from the officials a season ticket to their show and six complimentaries. In addition to that I was invited to speak at the banquet. There were speakers from California, many places in Oregon, British Columbia and Idaho. I guess the leading fanciers of the country were there from the west coast. One would speak and throw a lot of bouquets at the management of the show, then another would do the same thing, until they began to feel pretty good. Finally the judge gave an expression of his judgment regarding the birds. We were all glad to hear it. Then it happened to come my turn. I spoke and threw all the bouquets I had with me. I only had a few. Then all of a sudden I said: "Now, ladies and gentlemen, can't we talk about the serious side of poultry just a few minutes? As you are aware, I am representing a different line of work from that which you are engaged in," and I went on and told them how it was that 12 years ago I found our state was paying out $\$ 300,000$ for poultry and products per year, and last year we paid out over $\$ 4,000,000$. Twelve years ago there were three little struggling poultry associations in the state. At present nearly every county in the state has a flourishing association, and the demand for eggs is greater, and eggs are higher and higher year after year. Why is it that the poultry associations cannot relieve the situation? The sooner these associations realize that they are not together the better. We all like your birds and want to encourage you all we can in ycur work, but you must not forget that there is one thing you are neglecting in the Northwest." "I 
would like to know what that is," said the president of the association. "You are not teaching the people how to make a living with poultry; that is my business and I know you are not doing it." "We are." "Well, you will have to prove it." Then he began to get a little exasperated and said: "It seems to me we have had enough of this kind of talk. Mr. Blanchard came here and is pitehing right into us, and I for one, would like to have him take his seat." I said I would apologize for anything that I had said that was wrong, but I could prove anything I had said, and I believed the audience agreed with me, but if there was anyone person who objected to my speaking I would take my seat, so I took it. Then the president got up and literally skinned me. I sat there and had nothing more to say. He accused us of most of all the sins and of trying to destroy the work of the associations for the last 12 or 15 years by encouraging the mixing of breeds in order to get a greater egg production. He left the impression that we were favoring that policy. Then the toastmaster, who was a prominent attorney in the town, came to my rescue and explained matters, and notwithstanding the statement of the president that we must have no more of this talk, they would not talk of anything else for two hours, and the result was I got a chance to make an explanation to them that this was all wrong, because I candidly believed that the greatest number of eggs are going to be laid by the pure-bred bird, and I believed it was our duty to develop the pure breeds in the Northwest. I admit that one can eross two breeds and often get superior layers, but there are objections to doing that, serious objections that one does not encounter if he uses pure breeds. After the banquet this man came to me and apologized. We have a right to claim a part of this large amount of money that is sent abroad to the farmers of the Middle West and other places, and here is a business right at our fingers' ends, just waiting development. There is money to be made. There are millions of dollars being sent out of our state to which the farmers and producers are entitled.

\section{Keep One Breed.}

Q. Do you advise one breed for a big orchard?

A. Yes, keep the pure breed. It depends upon the extent of the poultry business. If one goes into the business and uses poultry as an adjunct to his orchard, chiefly for eggs, from an economical standpoint I would favor one breed.

Q. How deep do you dig the basement?

A. Not less than four feet; preferably six or six and one-half.

Q. How is it drained? 
A. We like to build where the drainage is natural.

Q. How high is the depth from the first story?

A. The front wall is 7 feet, the back wall is 5 feet. ing?

Q. How do you like the Corning system, about 1500 in one build-

A. That method is all right, but our experience is that in this country we get a larger profit per fowl in small flocks.

Q. What is the best method to keep a hen from setting?

A. Do business with a non-setter. There are certain breeds that rarely want to set. If one has the other breeds, he must have a good stock of patience. The main point is not to permit the broody hen to remain on the next over night. Our nests are so constructed that when the eggs are gathered every evening they are closed up. We have a little prison for them where there are no roosts nor nesting material, and where they can be fed just as regularly as though they were not broody. We find that, except perhaps in midsummer, it is not at all difficult to break up the broody hen if prevented in some way from remaining on the nest over night. If allowed to remain on the nest one night there will be trouble, two nights, lots of trouble.

\section{Incubation.}

Q. Can as strong chickens be hatched in an incubator as with a hen?

A. Yes.

Q. What percentage?

A. Last year out of 44 hatehes we averaged $881 / 2$.

Q. What incubator do you use?

A. An Eastern make, capacity 240. We tried it last year in a basement where conditions were very favorable. We tried this moisture machine alongside of a different kind, making the conditions to suit the latter, to determine the moisture needed for artifical incubation. At the same time we set three or four hens, making their nests on the ground. We noticed that the hens that steal their nests generally bring in the best hatches. The moisture machine was all through its hatching when the other machine and the hens were beginning their hatch. The chickens weighed more, and there was a larger percentage of hatch. By comparing one could readily see the difference in the flocks. Dead chicks in the shell is the great bugbear of artificial incubation. It is maintained that this is due to lack of moisture. The second machine brought off just as good a percentage of hatch, but one could tell the difference in the chickens. 


\section{Brooding.}

Q. Have you tried brooding without artifical heat?

A. To some extent successful. There is no question in my mind but what this can be intelligently done. One must exereise a good deal of common sense. One can brood chickens here in the country where it is damp and chilly, but whether it is the best way is another question. I would not attempt it in this country unless the brooders are heated and the chickens allowed to run out in the daytime. A lady called me up the other day and said she had some two-weeksold chickens and not one of them could walk straight. The trouble was she had them in the kitchen and was giving them all the corn meal and such feed they could eat. They had no exercise and their feed was making them weak. The remedy was to give these chicks more space and put in more sand for them to live on, and moisten it a little once in a while and mix the food in. Do not feed chicks until the third day. A man in Montana who heard that we were disposing of day-old chicks wrote asking if it would be safe to ship them that distance. I told him I would like to make the experiment, and if he would send in the order I would make the shipment, and he did not need to pay for anything he did not get. I thought he would order 50. Instead he ordered 1000 . We hatched out a thousand, and, to make good for those that might drop out on the way, I put in 46 , or a total of 1046 . I asked if he would please report what condition they were in. When he wrote he said: "One died on the way." These chicks were four days old without drink or food. Have you ever killed a chick hatched by a hen at the expiration of the first day and noted what she has been feeding it? You will find very little in its crop but sand, rock or grit. A hen is not in a hurry to take a chicken off the nest. Many times it will be the third day. We get some of these lessons very naturally. The first feed we give our young chickens when we hatch them in the incubator is sand and drink. Give pure water. If you wish you can mix in sand and some hard-boiled eggs, or some bread crumbs or something of that kind, but be sure they get sand and they will escape many diseases.

\section{Colony Houses.}

Q. Do you recommend colony houses in an orchard?

A. I would have the houses distributed a few hundred feet apart. It depends somewhat upon the breed of chickens one keeps in a house as to whether or not the flocks should be fenced off. If the 
coops are arranged 200 or 300 feet apart there will not be much mixing.

Q. What do you think of the Philo system?

A. It is all right. Whether it is practical, you must decide. Philo is an experienced poultryman, and what he can do with poultry perhaps you cannot. I might take his system and become disappointed. I do not think it is practical in an orchard.

Q. What was the average record of your 250 hens?

A. One hundred and seventy-seven eggs.

Q. How much land have you?

A. The land the building sets on. Our building is 130 feet long. We have it divided into eight rooms, leaving a feed room ten feet wide. The roosting rooms are 15 feet. There are 130 feet on either side of the building, a runway for each flock 20x50.

Q. What was the cost of feed per year?

A. For 18 months it was a little under $\$ 2$.

Q. What was the cost of raising them until 12 months old?

A. Under our system we have a hatch of chickens, say 100. We conclude that one-half of them are going to be cockerels and manage our business in such a way that when these cockerels are disposed of in the market the proceeds from them will have paid the feed bill of the pullets up to the time they commence laying, at about 5 months of age.

Q. When would you sell the Leghorn cockerels?

A. At 8 weeks of age.

Q. What do you get?

A. One can often get from 25 to 35 cents per pound. They will weigh one and one-half pounds at 8 weeks.

Q. Do you line breed?

A. Yes.

\section{Line Breeding.}

Q. Line breeding is what?

A. Line breeding is breeding from one family, just like the crowned heads of Europe. Take the pullets that you get from your pens that you now have and mate them to the male that you now have, then mate your hens with your cockerels from this year's hatch. Do not mate the cockerels of this year's hatch with the pullets. That is a mistake that is being made by many people.

Q. How do you do the next year, the reverse?

A. There is a system by which to avoid what is called inbreeding, yet you keep breeding in line continuously. In mating your fowls 


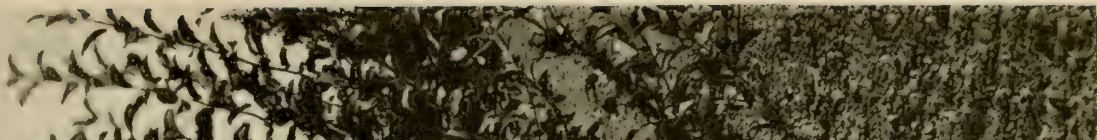

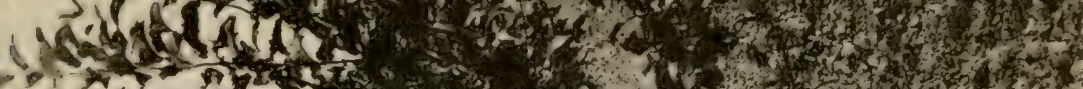

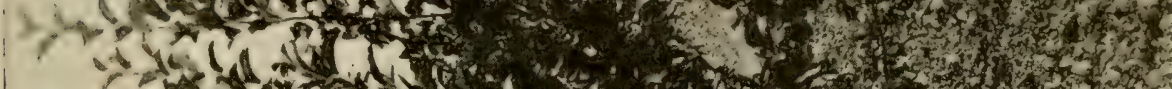

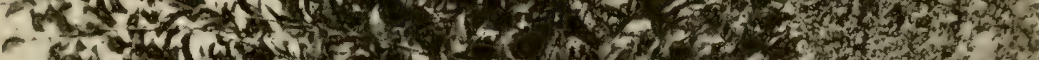

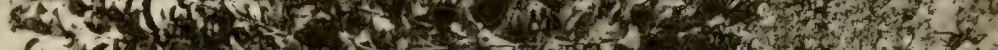

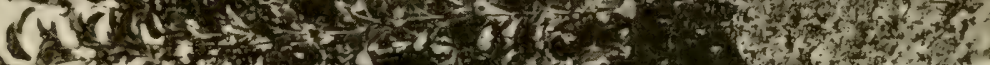

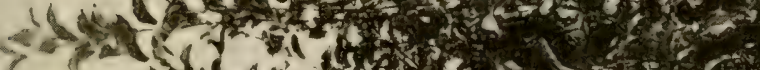

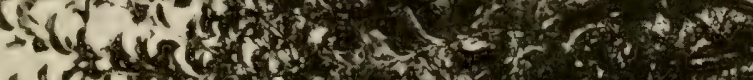

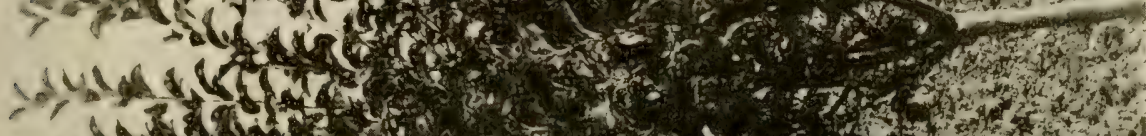

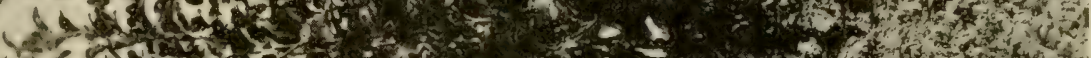

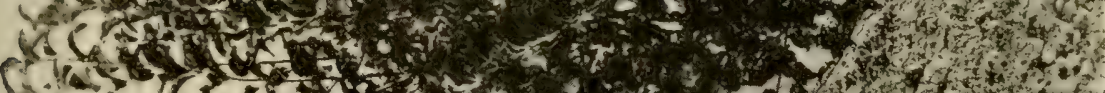

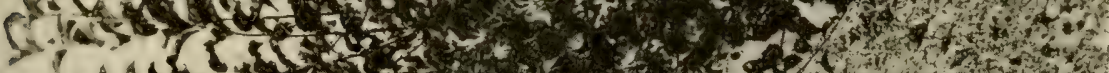

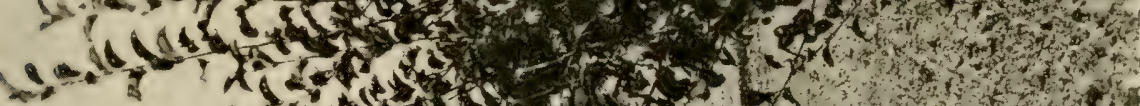

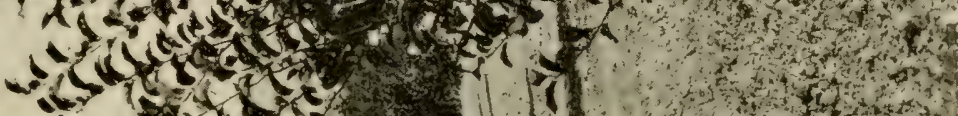
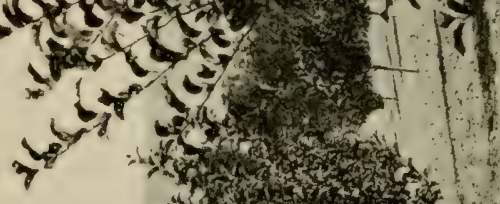

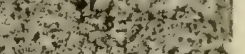

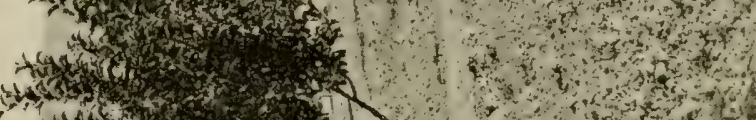

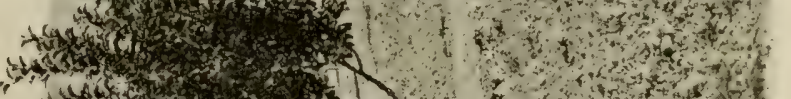

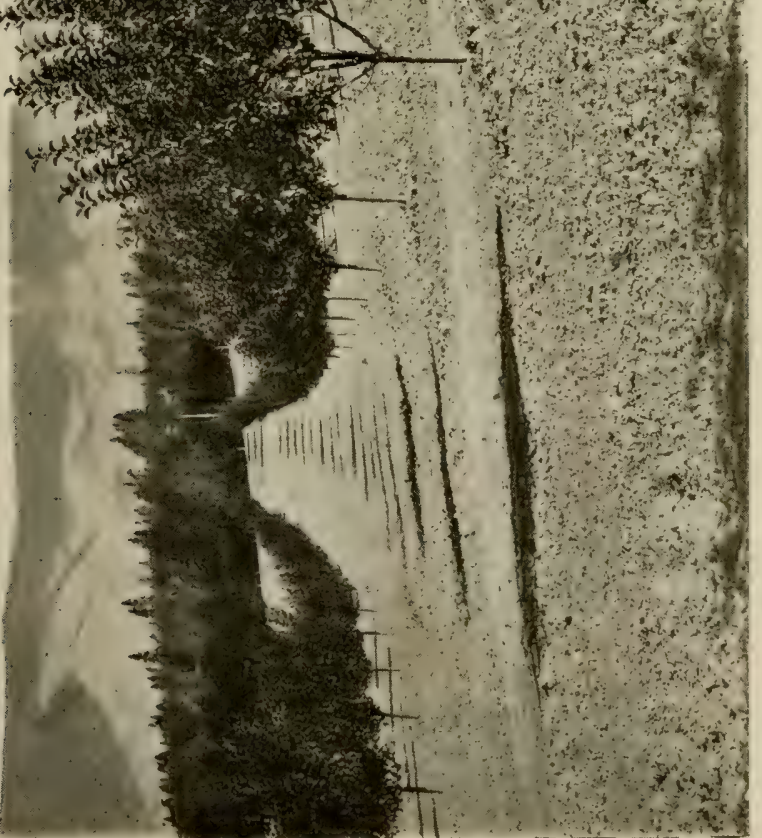


this year, if you mate up birds from the same flocks, you are making a mistake. Some people ean do that, but it requires skill. Some of the finest show birds in the country are secured in that way, but for utility purposes we do not attempt it.

Q. What breed do you favor?

A. White Leghorns, White Plymouth Rocks and Rhode island Reds.

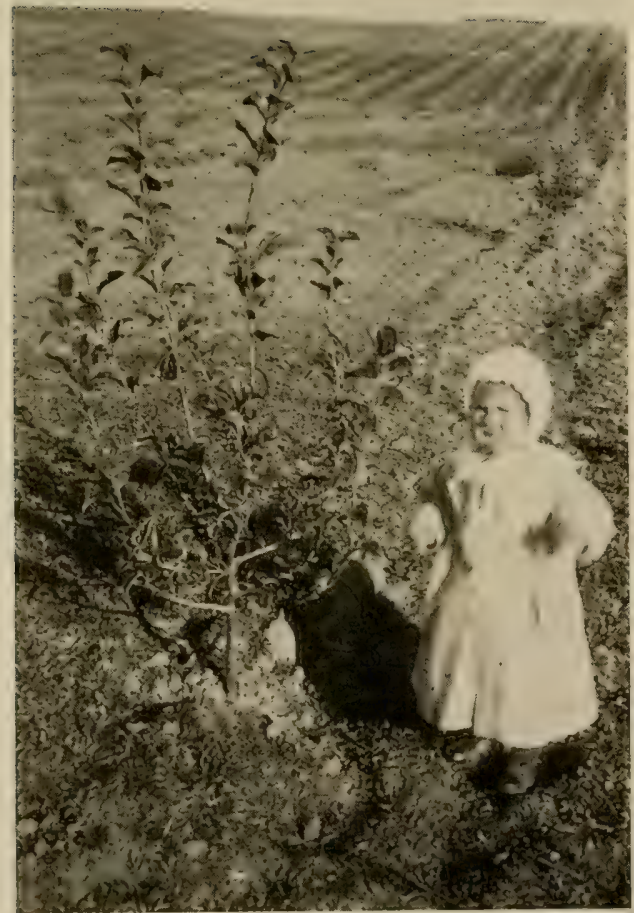

A Pair of Ortley Yearlings. 


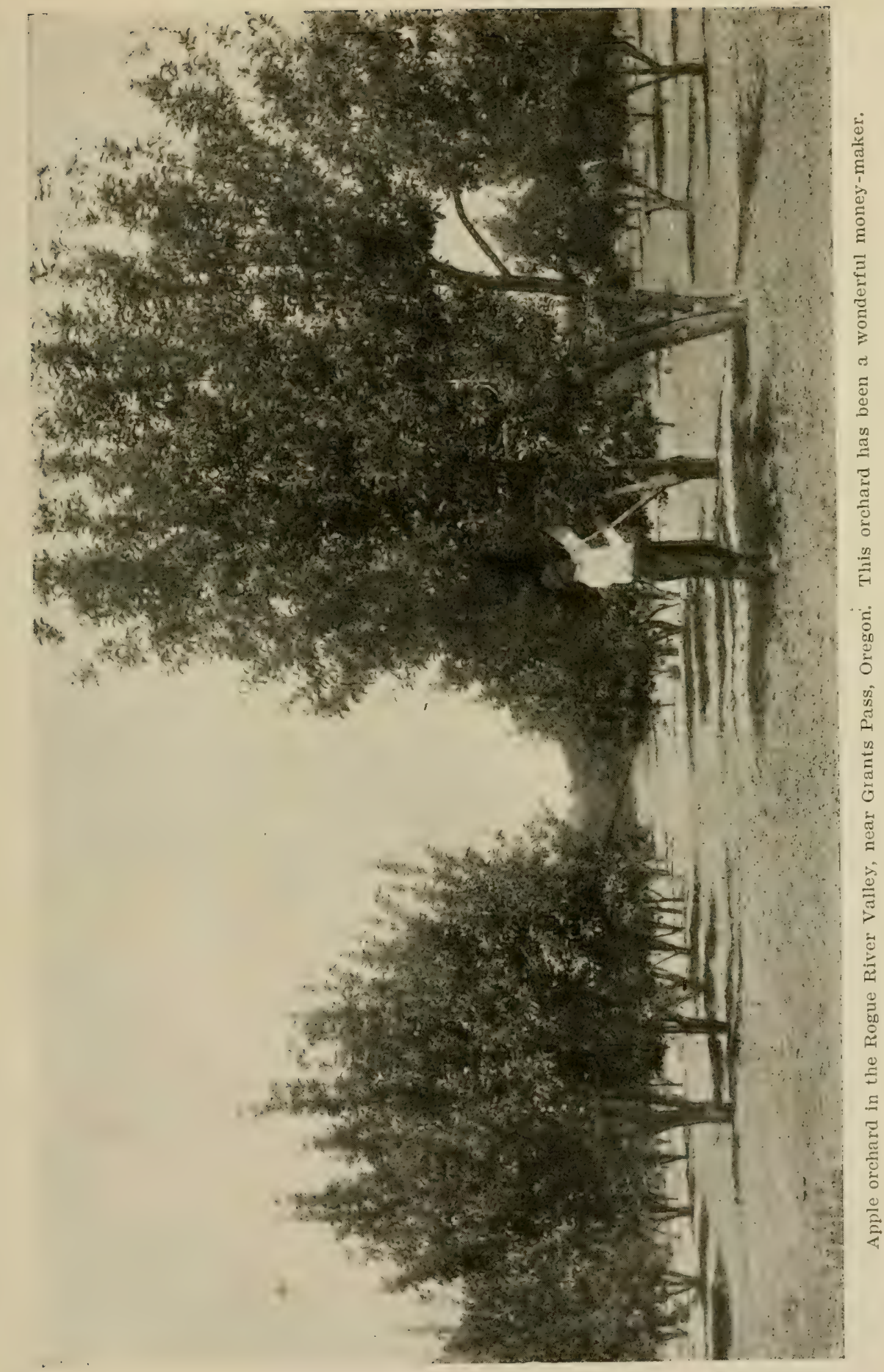




\section{Packing Apples}

Prof. Chas. A. Cole, of the Oregon Agricultural College. Y talk tonight will be along the line of handling and packing
apples, especially about packing apples. I have had quite a littie experience in handling classes in packing and I know just what a person is up against when he attempts to demonstrate apple packing. In my packing schools I have one assistant to every ten students. It keeps us busy seeing to what they are doing. Apple packing is an art or science just as much as painting pictures.

I have come to the conclusion that the Willamette Valley has the worst bunch of packers in the United States. In packing apples in boxes they do not seem to understand that they must pack one size of apples in one box and not put in everything in the orchard and try to work the small apples off. You get a little price for little apples.

The price that you get for your product is going to depend on just how you put it on the market and the appearance of the box. You would never think of buying a box with finger prints on the side of it, or one that had little apples mixed in with big ones, or lacked half an inch of being full. You would not think of taking that box when you could get one packed as it ought to be. If we are gcing to put apples on the market and get a high price we must use the best methods. I have seen packs from all over the United States and Canada and it is interesting to study them.

If you are going to put up a first class pack you must have first class equipment. When I say first class equipment for packing apples, this does not begin at the packing house. It begins in the orehard with the pickers. If you get a bunch of careless pickers that throw the apples around and bruise them, when they come into the packing house, it matters not how expert your packers are, they cannot put up a respectable looking box. If the apples are bruised they are going to show. Bruises will show on the Newtown Pippin in a very few hours. If you do not have a good packing crew and the proper equipment you cannot expect to get first class returns.

I will have some slides a little later showing some of the packing apparatus and the method of hauling apples into the packing shed.

First you want a good ladder, a light ladder that you ean move around the tree. You want some picking buckets that a man can 
handle. You do not want one that will hold half a bushel or a gallon. I use a three-gallon pail. You want to use a good substantial tin pail, a solid one with a hook on the bale that you can hang onto the branch. You want an orchard box that this bueket will fit down into. You want to prevent the apples from bouncing around on each other and you can't if you use a wide mouthed bucket that can't be lowered down into the box and emptied by placing one hand over the mouth, turning the bucket over on its side and allowing the apples to roll out gently.

We do not recommend patent pickers. Some of these pickers reach up and scratch off the apples. You don't want to use bags, bottomless or any other kind. When you get down to picking apples you have to be content with putting them in by hand. You need a good wagon, a wagon that is broad. Leave your packing boxes in the packing shed and use your field boxes. I nail a cleat on my field box and saw a hand hole in the side. This cleat has a special purpose. When the field box is set on top of another this eleat prevents mashing the apples. When one box sets down on top of the other the circulation of air is cut off, and where the air can't circulate the fruit is going to ripen up rapidly, so this cleat also affords good ventilation.

It is necessary to have a first class packing shed. There are very few in the state. A great many of the fruit growing sections have been developed by men who put every cent they had into 30 or 40 acres of land and were not able to build packing sheds. They depend on a barn in which to pack their apples. If you go over the various orchards you will find that these old sheds are beginning to disappear, and modern houses taking their places. In packing apples if the cold weather sets in, even two or three degrees above freezing, it will be necessary to have the packers protected from the cold, as it is slow work packing with cold fingers. You also want a house that can be ventilated, or one you can keep cool during the warm weather. When it gets late in the season you can't see to pack apples in the early morning or in the late afternoon. If possible you should light the packing house with electrie lights. This will insure better packs and longer hours. About the location. It should be located close to the railroad or right on the railroad if one runs through your place. If not, close to a public road. Some are so fortunately located that they can put the packing house in the middle of the field. Some have to go nearly a quarter of a mile to get to the packing house.

In equipping a packing house the first thing we look for, of course, is a machine for making boxes. I just use a common table with cleats nailed on the top of it. You can buy a box machine. A great many are used in California. I use a common table with a couple of cleats 
nailed on it. If I am using the California special, I put on the outside cleats so they measure 22 inches and put the ends of the boxes up against the inside of these cleats, and then nail cleats on the inside of the ends. This leaves a groove to hold one end of the box. Nail on a side using four nails. Turn the box over and nail the bottom on. It is necessary to hold the box steady while driving these nails in. I use a stripper. This is a piece of tin built up in the shape of a box with little grooves cut in it. It is fastened on to a carrying box. It looks like a wooden suit case and can be carried around with you. I got this from Hamilton \& Co, of California. The price is $\$ 10.00$. The fellows who have used it in factories say you pay for it in two days' work in the time you save.

I suppose there are more arguments over the packing table than any other one thing. I was demonstrating a packing table at the Apple Show at Spokane year before last and some said that method was as old as Noah's Ark. Some say you want to pack apples right out of the orchard boxes. They pack right into the other boxes without grading or sorting. If you have ever tried to put up a box of apples out of one bushel you will know how uniform they get the pack. It takes 8 bushels to put up one box of one size. I have seen people pack a box out of a bushel. You can't do that and get your apples uniform. I am going to use a packing table until they show me something better. What I mean by a packing table is just $a$ common table. I make one for my own use low enough so I won't hit the boxes when I am working. This table is about $30 \times 40$ inches at the top. I seldom make them square.

\section{Directions for Making a Packing Table.}

As I said before, I would build the table so that the top will measure $30 \times 40$ inches, and at such a height that one packer can just touch the bottom of the box with the tips of the fingers when setting on the rack without having to bend over. The material necessary for this table will be four planks one inch thick and seven inches wide. The planks for the side will be 40 inches long, for the front 30 inches and the back 54 inches. The plank for the back extends out one foot on each side, making a part of the box rack. Now take four $2 x 4$ s for the legs. These should be cut so that when the table is put together there will be no sharp corners sticking out to bruise the fruit. Now put this framework together. Cut another plank of the same width and length of that used for the back of the table. This plank goes. through under the table to form the remainder of the box rack, and should be placed so that when an Oregon Standard box is placed on 
the rack the lower end will come to the center of it. This gives the box a slope towards the packer so that when he places an apple it will not roll. Now put on the top. I use common burlap, the kind that is used to wrap furniture. This can be had from furnishing stores for about 7 cents per pound. Tack on the burlap so that there is not over one inch sag. If given much more slack than this it will hit the board that forms part of the box rack as soon as a load of apples is put on. If possible I nail a piece of old garden hose around the top to protect the fruit from the edges of the planks. Be sure and brace the legs of the table so there will be no danger of a breaktown. This table will accommodate two packers.

We are now ready to begin on the apple packing. I use two types of boxes, one Oregon Standard and the California Special, the dimensions of which are given in the "Table of Commereial Packs." These boxes are wider than they are deep. Many people get it just the reverse. These are the two sizes of boxes we use in the packing house, and they are used in the Hood River Valley exclusivly, in this valley some and in the Rogue River Valley to some extent. Most people there use the California Special, which measures a little different from this. Some run 22 inches and $91 / 2$ inches deep. They do not like the Oregon box, I don't know why. Besides your two size boxes you want two sizes of lining paper, two sheets to line each box, and two sizes of layer paper and one size wrapping paper. This completes your equipment unless you want a complete set of stamps. I buy my stamps made separately. I made a rack to hold the stamps and stamp the number right over each stamp so I ean reach in and pick up a stamp without stopping to look at it. I have a stamp for the name of the apple and for the tier.

No first class apple packer would ever think of packing apples until they have been graded, wiped and culled. Some tell me this is useless. If you just stop and think you will see it is impossible to put up a good box of apples out of a lot that has never been graded or culled. If your apples were all the same size without a worm hole or a San Jose scale, or a bruise of any kind you could do this. They are graded into extra faney and orehard rum. We might call them first and second. Grade them to two or three sizes. If you grade them down to nearly the proper size of packing it will take too many boxes. Put all 41/2-tier and smaller in one box and all larger than $41 / 2$-tier in another box so that the packers wont have to do so much assorting when packing. If you put too many sizes on the table the packers will bruise them in assorting. The advantage the table has over the box is that it has a large surface and gives you a large number of apples to select from and you can put up a uniform pack. In 
culling you should only put the apples without a blemish on them in the fancy stock. You don't want any wormy or scabby apples in the second. In wiping the apples you want to wear gloves-just canvas gloves. Get them with the woolly side out.

I have one or two slides showing my packing school and the apparatus that we use. I want to show you what a packer has to learn to put up before he is an expert. Four weeks is a short time to teach apple packing. It takes years of experience to make a good apple packer. I have a friend that packed two or three seasons. He packed nine boxes the first day and by the end of the season 45. If a man packs 50 a day it is a good day's work. Some pack as high as 80 or 100 boxes a day. They pack so fast they could not see whether there was a worm hole in an apple or not. Everything goes.

\section{Table of Commercial Apple Packs.}

\begin{tabular}{|c|c|c|c|c|c|c|}
\hline Box & Tier & Pack & $\begin{array}{c}\text { No. apples } \\
\text { in row }\end{array}$ & $\begin{array}{l}\text { No. rows } \\
\text { in width }\end{array}$ & $\begin{array}{l}\text { No. layers } \\
\text { in depth }\end{array}$ & $\begin{array}{l}\text { Apples } \\
\text { in box }\end{array}$ \\
\hline Stan. &. .3 & Str. 3 & 5.5 & 3 & 3 & 45 \\
\hline Spee. &. .3 & Str. 3 & $6-6$ & 3 & 3 & 54 \\
\hline Spec. & $\ldots 3$ & Str. 3 & $7-7$ & 3 & 3 & 63 \\
\hline Stan. & $\ldots 31 / 2$ & Dia. 2-2 & 4-4 & $31 / 2$ & 4 & 64 \\
\hline Stan. &. .3 & Dia. 2-2 & $4-5$ & $31 / 2$ & 4 & 72 \\
\hline Stan. & ..31/2 & Dia. 2-2 & $5-5$ & $31 / 2$ & 4 & 80 \\
\hline Stan. & .. 31/2 & Dia. 2-2 & $5-6$ & $31 / 2$ & 4 & 88 \\
\hline Spec. & $\ldots 3$ & Dia. 2-2 & $6-6$ & $31 / 2$ & 4 & 96 \\
\hline Spec. & $\ldots 31 / 2$ & Dia. 2-2 & $6-7$ & $31 / 2$ & 4 & 104 \\
\hline Spec. & $. .31 / 2$ & Dia. 2-2 & $7-7$ & $31 / 2$ & 4 & 112 \\
\hline Spec. & . . 31/2 & Dia. $2-2$ & $7-8$ & $31 / 2$ & 4 & 120 \\
\hline Spec. & $\ldots 4$ & Str. 4 & $8-8$ & 4 & 4 & 128 \\
\hline Spee. & $\ldots 4$ & Str. 4 & $9-9$ & 4 & 4 & 144 \\
\hline Stan. & $\ldots 41 / 2$ & Dia. 3-2 & $6-6$ & $41 / 2$ & 5 & 150 \\
\hline Stan. & $. .41 / 2$ & Dia. 3-3 & $6-7$ & $41 / 2$ & 5 & 163 \\
\hline Stan. & $. .41 / 2$ & Dia. $3-2$ & $7-7$ & $41 / 2$ & 5 & 175 \\
\hline Spec. & $\ldots 41 / 2$ & Dia. $3-2$ & $7-8$ & $41 / 2$ & 5 & 185 \\
\hline Spec. & $\ldots 41 / 2$ & Dia. 3-2 & $8-8$ & $41 / 2$ & 5 & 200 \\
\hline
\end{tabular}

When a standard box is used 96 and 112 are packed four tier, and 200 will pack five tier.

96, 104, 112 and 120 may be classed as four tier apples, and 185 and 200 as five tier.

128 size long Spitz and Ben Davis may be packed 125 to the box. 
Flat apples like the Wagener may be packed four tier by placing all on the side.

Sizes of boxes: Oregon Standard 101/2x111/2x18 inches. California Special 10x11x20 inches, inside measurement.

\section{Questions and Answers.}

Q. Do you think apples are packed better if allowed to sweat two or three days before packing?

A. No, I do not think so. I have never noticed any difference in apples that came direct from the packing house. An apple will not get crisp in two or three days.

Q. Do you pack every apple diagonally?

A. You can come pretty near it. You can pack 155 and get a diagonal pack.

Q. How about apples like the Red Cheeked Pippins that are high on one side and flat on the other?

A. You can pack out a bulge by turning the apples.

Q. Is the Ben Davis a profitable apple?

A. Some people say it is. It makes a good apple to grow for five years then graft. A great many people say they make their money on Ben Davis stock, but they get a very small price for it.

Q. What do you think of the Northern Spy?

A. It is a fine apple. It is one of my favorite apples for eating. It is an apple the Easterners say reminds them of home. following?

Q. Is a tree pruned the same the first four years as the years

A. When I set out a tree I prune it for three years, then I slack up on it and allow it to form some fruit spurs. Do summer and winter pruning from the time the tree is set out. I always prune a bearing tree during the summer. Summer pruning should be done in July, then you do not get water sprouts as you do in the winter.

Q. Do they raise Rhode Island Greenings here?

A. Yes, but the Easterners do not recognize them. We grow Rhode Island and Northwest Greenings, but they do not taste like the Greenings in the East. I have seen them with red cheeks out here instead of green as in the East.

Q. Would you hesitate grafting a tree ten years old?

A. There are three systems of grafting. The cleft, bark grafting and making a cut in the edge of the stub. Some object to eleft grafting as they say that the cleft offers a good opportunity for disease to get a hold.

Q. Do you have any success in grafting an old root?

A. If you want to do root grafting you should use but one year old roots.

Q. For young roots do you prefer the grafted or the budded?

A. I should prefer budded. 


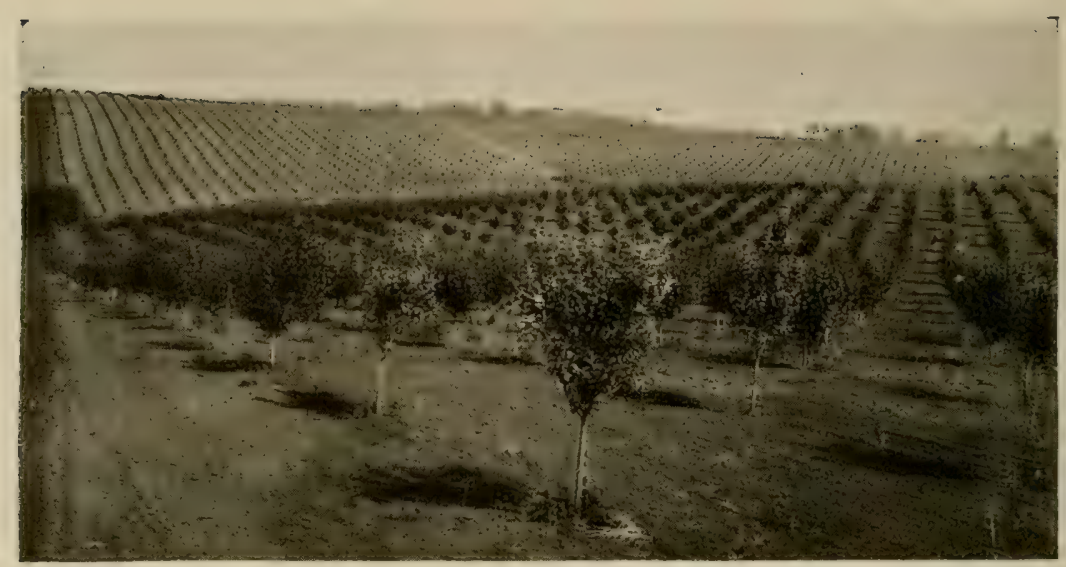

Orchard near Silverton, Oregon, in the Willamette Valley.

\section{Organization for Marketing Apples}

Homer C. Atwell, President of the Oregon State Horticultural Society.

I $\begin{aligned} & \mathrm{N} \text { presenting this topic to you, I am troubled with the fear that } \\ & \text { you may have been led, through a recent item in the press, to }\end{aligned}$ expect that $I$ intend to deliver here a formal address. The press notice alluded to was kind enough to say that I would deliver here the same address that I am expected later to deliver in the State of Washington, and that I had been preparing it with great care. Perhaps I should be tempted to follow my journalistic friend's hint, if I had that address prepared. However, as it is yet to be evolved from my inner consciousness, I shall be content to rest on Mr. French's injunction to make my effort strictly an informal talk, as "The club won't tolerate a formal address."

With this preface, I will return to the main question, Who will eat your apples? You can't do it yourselves. Portland can't do it. The Pacific Northwest can't do it. Apple growing has now passed beyond the sentimental and aesthetic stages, and has evolved into a vast productive industry, demanding development along commercial lines.

The apple industry, like every other, has two phases, production and distribution. Discussion groups around these two main topieshow to grow apples and how to dispose of them.

Growing apples involves consideration of such topies as location, soil, planting, pruning, cultivation and spraying-important, certainly and vital to success. They are, however, in a sense, elementaryquestions for the agricultural colleges, for the farmers' institutesquestions for solution of which we turn to our professors and horticul- 
tural experts, and to the books. Their principles are old and well tried out. They are, nevertheless, new and always interesting, because varied conditions of various districts require discriminating application of these principles, readjustments to changed (a)nditions. These questions are, as I have said, questions for the student, problems for the producer to work out in his own environment, in his own orchard, with factors under his own management. He is master of his own workshop and of his own tools. Results are under his own control.

When, however, you have grown your perfect apples, and have them properly packed, your work is done. You stand helpless before the next problem. Upon its solution depends return for all your past labor and study. Before this problem, your teachers also are helpless. The colleges can't solve it. The books are unresponsive. What will you do with your well-packed box of fine apples? That is the new problem, the problem of distribution. This may not be quite so interesting as how to train a tree in the way it should grow, nor quite so fascinating as "lime-sulphur spray in combination with lead arsenates." I think, however, you will agree with me that it is quite as important to the man who grows apples.

The time has passed when apple growers of the Pacific Northwest can depend on local markets. Nuch less shall we be able to do so, when we produce annually 100,000 ears of apples. as President Elliott. of the Northern Pacific Railroad predicts we shall do, in the near future.

We must rely on interstate and foreign markets. At that point we approach a problem not in the books we have been studying, one that is outside the producer's sphere and means of control. It is the problem of distribution.

You and $I$ are producers. Production and distribution are distinet processes of economic activity, and are worked out by different sets of actors. However, although they are distinct, and although producers cannot directly control processes of distribution, they may largely influence them, by organization for that purpose.

Before developing this idea further, let us take a brief survey of the machinery of distribution, as it applies to sale of our apples. Teet us assume, for example, that we are an apple-shipping association, located in the Willamette Valley. We shall, of course, make estimate. in advance of packing, of probable number of cars we shall have t" ship. We shall endeavor to make our sales on the basis f. o. b. here. This means, of course, acceptance at stipulated price, at shipping point. subject to condition that goods, upon arrival, shall conform to representations. We solicit Eastern dealers for orders. We quote them prices, grades and sizes. Market is dull. Buyers are indifferent. 
Meanwhile apple packing time arrives. We soon pack and ship out enough cars to fill our orders, and still have the bulk of our product unsold. We are no longer able to effect sales f. $0 . b$. This is especially the case when Eastern markets are crowded, or business conditions depressed. We must, nevertheless, continue to move our product forward. Cars can't be had whenever wanted. When furnished, they must be filled. Another consideration impelling us to crowd shipment is lack of storage facilities at home.

Independence of immediate market conditions is one of the principal objects to be sought by fruit-shipping organizations. This independence means prolonging our shipping season. It cannot be attained, however, without adequate storage facilities here.

I notice by the press that the people of Hood River, who, of course, are always on hand when there is any improvement to be made, are planning to extend their storage facilities, in order that they may not be compelled to hurry their fruit onto the market.

To resume our illustration, let us say that we bill our car to Chicago. Before it has reached Cheyenne we learn that Chicago is overstocked, and we order the car diverted to Minneapolis or to Kansas City. We may again divert it to Atlanta or New York. All the time that car is rolling eastward we are keeping the wires hot to find the best market for it. The routing clerk in our office keeps close tab on that ear. Just as the train dispateher of a railroad can tell you at any moment between what two stations any train on his road is, so our routing clerk knows approximately the location of that car at all times. Until sale is finally effected, or point determined upon which our manager considers most promising, he is wiring to various sales agents description of that car, stating number of boxes, varieties, locality where grown, grade and number of apples in a box. This is expensive business, especially when a car contains 20 varieties of apples, as was occasionally the case during the past season.

Suppose now, instead of one car, we are handling three cars a day. This would not be a large business. Let us assume Chicago to represent average distance between Portland and various Eastern marliets. It takes eight days for a car to reach Chicago. Multiplying this number of days by three, you have 24 cars in transit all the time during the shipping season. All the time our manager is telegraphing over the country regarding each of these cars. Our routing clerk is all the time changing position of pegs on his routing map.

This brief outline of the activities of one small shipping association, such as will naturally grow up at a score of towns in the Willamette Valley, indicates the complexity and expense of apple marketing, and also the high degree of skill and judgment required. 
Perhaps you now appreciate more clearly the force of my statement of a few months ago that production and distribution are distinct processes of economic activity.

However, the producer should know something of the processes of distribution, in order better to adapt his own operations to their requirements, and in order to contribute, through organization of producers, to make distribution more effective.

Assuming that I have satisfied you that marketing on large scale and under modern conditions is not for the individual, let us consider how large should be the scope of such shipping organizations, in order to effect best results. I will lay down the proposition right here that it should be as large as possible, should control the output of as many growers as possible. We will work up to demonstration of that proposition.

It is a conservative estimate that at the present time there are 50 individuals, companies and associations, shipping apples from the Pacific Northwest. Each of these has the same experience I have outlined. Each incurs the same items of expense for acquiring information. They not only duplicate one another's expense account, but each adds to expense of the others. Shippers A, B and C have overstocked Omaha. Shippers D, E and F have no means of finding this out except by independent expenditures for telegrams.

These independent shipping operations not only cause great duplication of expense but unavoidable glutting of many markets. This cannot be avoided altogether by any amount of expense for telegrams, as a market that is promising today may receive cars from half a hundred shipping associations tonight.

Our present unorganized distribution also often leads to ignoring some markets altogether. In the United States there are 180 cities of over 25,000 population each. Greater consuming ability of leading cities causes tendency of shippers to concentrate their offerings there. It is generally admitted that, in the rush to supply greater markets, many lesser ones are altogether overlooked. These, in the aggregate, have capacity for consumption of large output.

You will observe that I have thus far touched only on attempts to supply existing markets, markets where demand is already well defined. These, if evenly supplied, would in the past have absorbed most, if not all, our output. Prospective increase of population, however, will necessitate opening of new outlets, development of demand now dormant. These are avenues which are closed to your average shipping association, because it lacks sufficient financial backing. It can't afford to pay from $\$ 5,000$ to $\$ 10,000$ a year to a manager who has intimate knowledge of the world's market and of international 


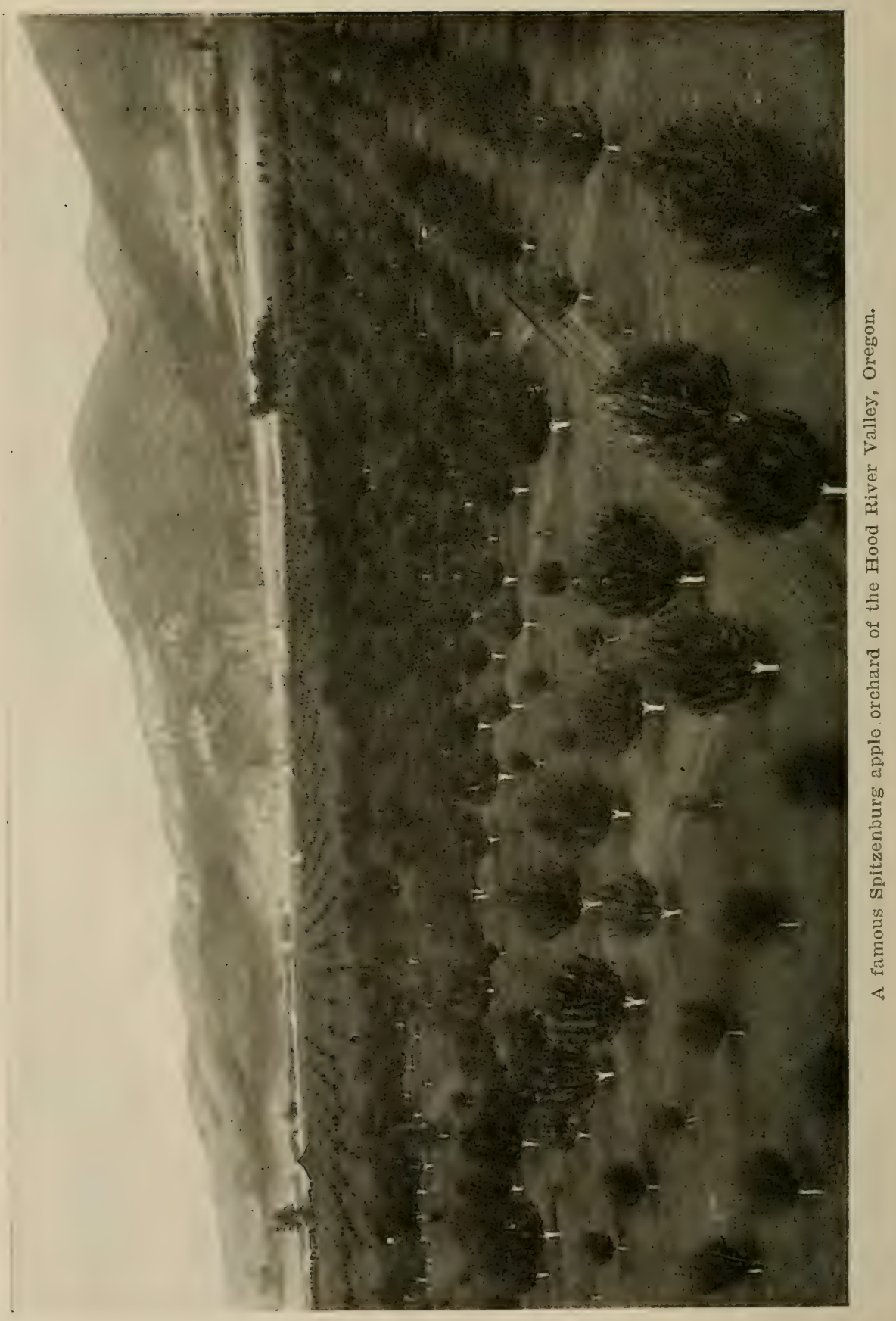


trate relations. It can't afford an expenditure of $\$ 50,000$ a year to advertise and exploit our product in lands herefofore unsupplied, or inadequately supplied with apples such as we produce.

Thus you see that our present system of independent shipping not only results in duplicated expenses, glutting of large markets, and overlooking of small markets, but also proves inadequate to the expansion of markets which our inereasing output demands.

Were these 50 individual and corporate shipping concerns amalgamated under one management, results would be quite different. We would then save many thousand dollars in expenses now entailed through duplication of effort, and yet would be able to pay our manager and Eastern salesmen salaries that would command the best talent and experience in the country. Levying a trifling toll on all output would give our association a fund that would enable it successfully to storm many a market now unavailable. Glutting of larger markets would be prevented. Smaller markets would be supplied as thoroughly as larger ones. This fact alone would largely increase demand. Demand, however. would be greatly stimulated by lower price to consumer. caused by elimination of superfluous agents, and hy use of other means of cheapening distributive methods. There is no economic fact better established than that price affects consumption. The cheaper a staple article is, the more it is in demand.

The great bulk of the apple output must be consumed by the common people. Their capacity of consumption is tremendous. We sh:uld see that that capacity is kept at its maximam proportion by placing our product in their hands at a reasonable price. This would be possible under central control of distributive agencies. It is impossible. under present methods of competition and duplicating expense. Consumption would be further inereased by rigid adherence to uniformity in grading and packing, by which confidence of buyer would he increased and popularity of our fruit enhanced. A central selling organization could maintain such uniformity.

But, you may say, lower price to consumers will mean lower price to producers. Not at all. Organization such I advocate would increase average net financial returns to growers by steadying market condition, by preventing losses and unremumerative sales. by eliminating wasteful methods of distribution. You may divide, in any way you like, the amount realized from greater economies and greater efficieney. Any fair division will result in lower price to consumer and greater profit to producer.

There is another way in which an organization controlling the output of the Pacific Northwest would result in great saving to growers. It is in the matter of purchasing supplies for orchard use and for 
packing. Certainly a concern doing an annual business of $\$ 50,000,000$ should be able to secure wholesale prices.

Large part of the fruitgrowers' associations of Pacific Northwest, as they are at present constituted, are worse than useless for effecting distribution on large scale. Better that the apples of a particular district should rot on the ground than that the entire industry should suffer from ill-timed and poorly-managed effort to force their sale. Weakness of these local associations lies in their lack of financial resources. They undertake to do what they have not, and never will have, facilities to accomplish. Elimination of selling function from scope of their activities will leave them free to attempt what is possible. Strong local associations are absolutely necessary as pillars on which an organization for wide-scope distribution must stand. Their functions, however, must be developed along new lines. Capital and properly-paid local management will be the first requisites to be supplied.

My ideas are not altogether original. I had the privilege of testing their soundness during the winter of last year, in southern California. There one must pay close to $\$ 2000$ an acre for a good bearing orchard of oranges or lemons. This valuation is not based alone on climate. Basic factors of that valuation are strong local associations, with ample capital and competent management, and, over all, a central selling agency to whom an expenditure of $\$ 50,000$ is a matter of small importance if it secures results.

I have thus far touched upon the purely practical side of this question. There is another side quite as important. Economists and students of social problems agree that future welfare of our nation depends on arresting the current long drifting from country to city, a movement which is slowly draining our rural districts of their best manhood and womanhood, congesting our urban centers, increasing cost of living and consequent general discontent, and menacing our civilization with threat of various dire evils.

It is our duty to encourage an opposite movement. Apple growing affords the strongest lure to rural life. We should then bid godspeed to him who-lives under the shade of his own apple tree. We cannot, however, conscientiously extol a vocation which offers no hope of adequate financial return.

Apple growing, like any other department of agriculture, must be made to pay, if our farming districts are to be filled with a contented and proud people. It is our duty to make it pay, by abandoning inefficient methods, and adopting those methods which the extent of our industry necessitates, and business sagacity dictates. 




Orchards on a Thousand Hills.

\section{Questions and Answers.}

Q. Will the opening of the Panama Canal cheapen freight rates?

A. I think so. I have great faith in the future of the fruit industry of this Pacific Northwest, especially in the districts contiguous to the coast, because of the promise there is in the opening of the Panama Canal. It will not only cheapen our freight rates to the East, but it will increase the length of our shipping season, provided we prepare for it by establishing sufficient storage facilities at this end. We hasten shipments now on account of approaching cold weather. Danger from that source would be eliminated by erecting adequate cold storage warehouses and by shipping over the canal route.

Q. How would the production of apples have to be increased to sustain now a central organization?

A. The production of apples in the Pacific Northwest would not have to be increased at all. If all individuals and shipping associations now shipping apples from the Pacific Northwest would combine, or a large proportion of them, they would be able to do business at a 


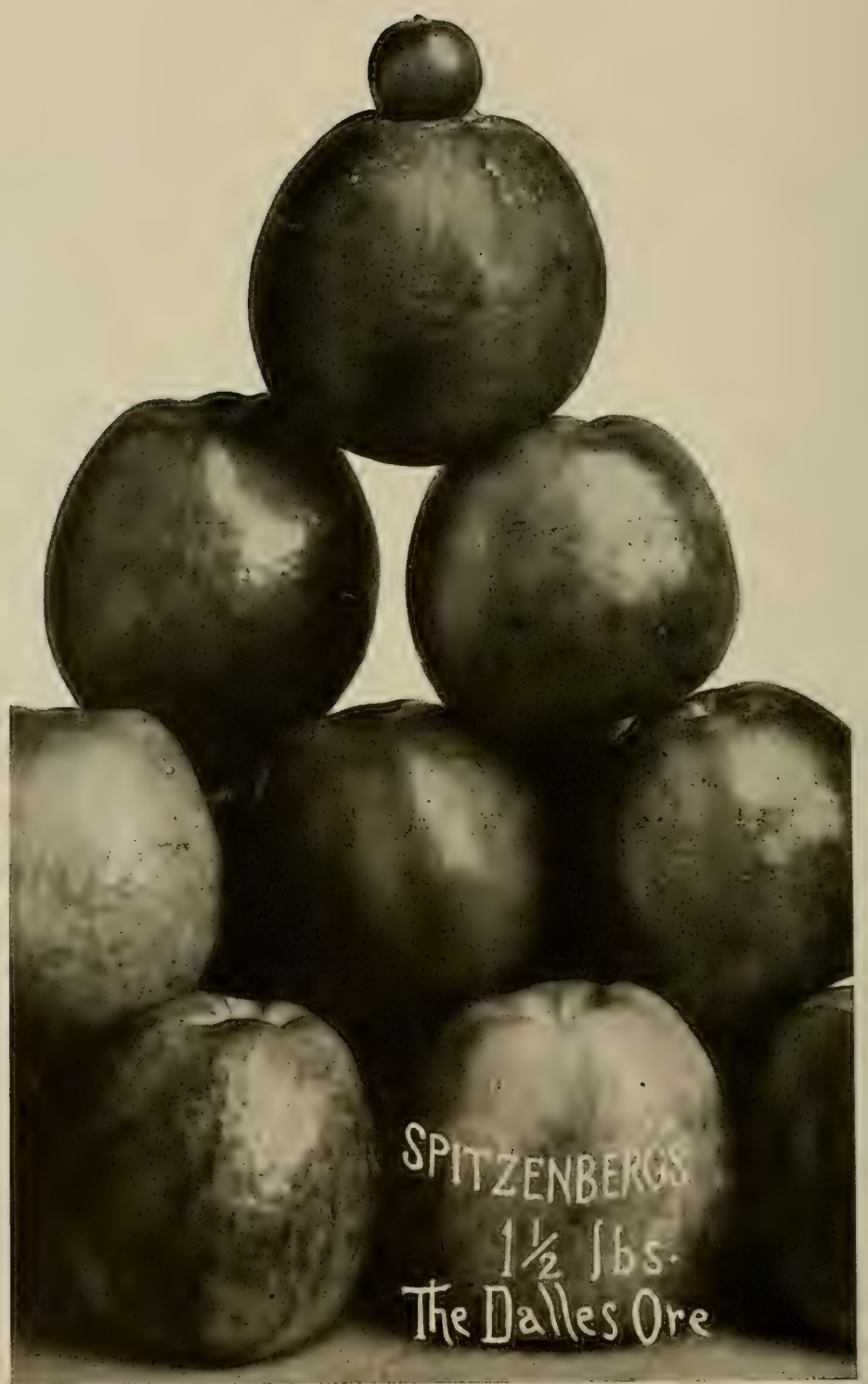

They speak for themselves. 
sufficiently small cost, so that a very trifling toll upon that business would give them all necessary funds for exploiting the industry and for building storehouses and warehouses. I have seen estimates of what 5 cents a box would accomplish on the output of the Northwest. I do not recall it now, but it would be a very large sum. I think that the apple output of the Pacific Northwest in the near future should reach as large proportions as the citrus output of California.

Q. What is their output?

A. According to statisties compiled by the California Fruit Grower, a very careful and reliable publication, the output of that state for the season of 1909-10 was 33,099 cars. I have seen no estimate as to the value of this output, but I would say that $\$ 1,000$ per $^{2}$ car would not be far out of the way. This, you see, would make the total value something like $\$ 33,000,000$. Year before that it was over $\$ 40,000,000$.

The California Fruit Growers' Exchange, to which I have before alluded, handles about 60 per cent of the total output of citrus fruit from that state. It does this at an expense to growers of not to exceed 3 per cent on gross sales. The amount thus realized enables the central association to employ an exploitation force of the highest business ability. They pay their manager $\$ 8,000$ a year, and salaries to Eastern representatives in proportion. They have spent as much as $\$ 50,000$ in one year in advertising their fruit. All their business is done on that scale, and yet you see the burden of maintaining that organization is very light.

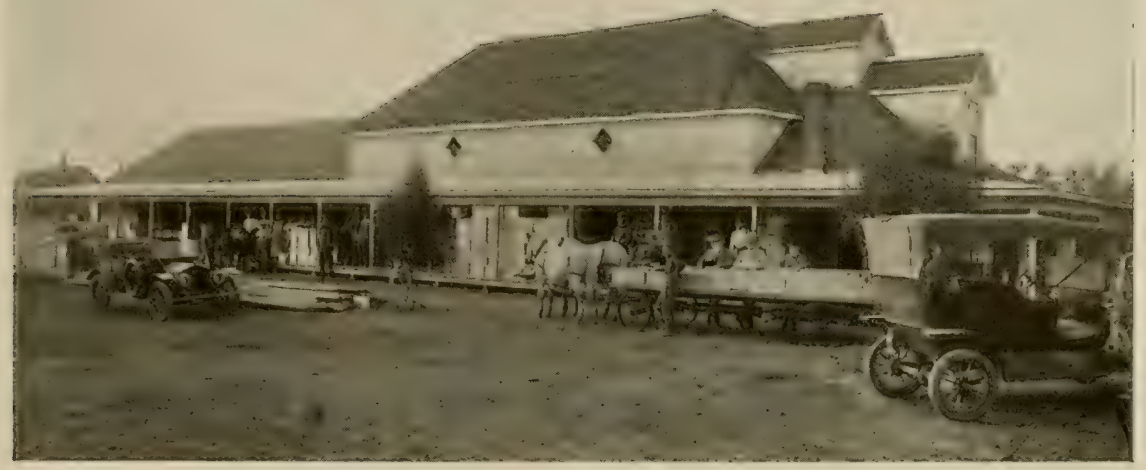

An apple packing house in the Hood River Valley, Oregon. 
Q. What per cent of the fruit of the Pacific Northwest is now handled by the fruit growers' associations?

A. I am not positive on that subject. In the State of Washington there are several very strong private shipping companies. I really ought not to make an estimate on that point.

Q. Would private association join this central association?

A. That is a large question and I have not gotten far enough along in the game to be able to answer it. Of course, I suppose you know that we are trying to build up such an organization in the Pacific Northwest?

Q. What cffect would the 100,000 carloads that you predict in the near future have on the market? How much reduction would there be in the price? Would apple raising still be profitable under that condition?

A. Yes, I think so. The expectation is that, either this year or next, we shall effect the only desirable and only efficient means of disposing of this oncoming product-that is, a central selling agency. I think we shall have it. If I did not think so, I should not want to remain in the apple business.

Q. Supposing this 100,000 carloads is duplicated in the Mississippi Valley?

A. They should acept a central selling agency also. The same would be true of other extensive districts having large output. Two or three big organizations like that can work together, but a lot of little local organizations cannot. I do not think we need be haunted by the fear that the entire country will experience the same degree of expansion in apple-production that we expect in the Pacific Northwest. There must he production of other commodities than apples. The result will be that each district will settle down to production of that for which it is best adapted.

Q. What is the boundary of the Pacific Northwest?

A. Bounded on the west by the Pacific Ocean, on the north by British Columbia, and on the east, for the purpose of apple-production and apple-shipment, I will include Western Montana and the west slope of Colorado. I do not think the Pacific Northwest would include ralifornia. You probably know that the great bulk of the box apples of the country are produced in the Pacific Northwest. The boundaries I have mentioned, including also part of California, produce large quantities of apples and they box the most of them. If the people who put up apples in that form can combine they can control the box apple situation at present.

Q. Are they not boxing their apples also in the East?

A. They are to a small extent. 
Q. Are they not advocating that in the New England States? Is not apple culture growing rapidly in favor there, clearing up their old orchards?

A. As far as clearing up their old orchards is concerned, that would not do them any good, their trees are so high up in the sky; but they are planting new orchards. That is true. There is quite a revival of apple-growing in various districts of New England, but not to the extent there is out here in this country.

Q. There was an article in the Saturday Evening Post, not long ago, telling what they are doing there.

A. Yes, that is true. I have the article at home. But referring to clearing up their orchards, perhaps I was a little hasty in jumping at your suggestion. The writer was not speaking so much of clearing up, as retopping. They may make them pay in that way.

Q. If we should form this organization as you suggest, would there be danger of our being branded as a trust?

A. I do not think so. I think that our courts have decided that an organization that is formed for the purpose of economizing in methods of distribution and making even distribution, and making lower prices to consumers (and that is what we would be doing; that is our only object) is no trust.

Q. Would it be possible for the association to sell the same as the Citrus Fruit Association, by auction?

A. Well, there is a good deal more of it done now than should be done. It is done in Chicago, Minneapolis and other large centers. I saw that worked out in Chicago last summer, and I was surprised to see how fairly it was done. Every morning in the week a large number of local dealers get together in an auction house. They first inspect the fruit, and then they go upstairs and wrangle there sometimes until the middle of the afternoon, bidding on that fruit. If the market happens to be glutted, however, you see they are not going to bid very much. The auction houses are not desirable, if you can sell in any other way. The California Fruit Exchange sells both ways.

Q. Would it be the design of the organization to sell direct?

A. I would say that that would be a primary object. You can see yourself it would be more satisfactory to sell your product at a certain price than to send it back and not know what you are going to get.

Q. What per cent do the growers expect to save through having an organization?

A. There is a wide variation; all the way from 1 to 100 per cent.

Q. Would it be the idea of this central association to maintain storage plants in the East or here? 
A. My idea would be to erect storage plants here for the most part. It may be found desirable to have some storage plants in the East, but I think it would be better policy to hold the fruit here. as far as possible, until sold. When those Eastern dealers see thousands and thousands of cars of fruit on hand, it makes a great impression on them. They think apples ought to be cheap (to them).

Q. If you had a central storage plant in the East, would you not be able to distribute there direct to the wholesaler instead of jobber?

A. Well, of course, having a storehouse in the East would give you that trade, especially if you wished to supply a wholesaler with less than carload lots.

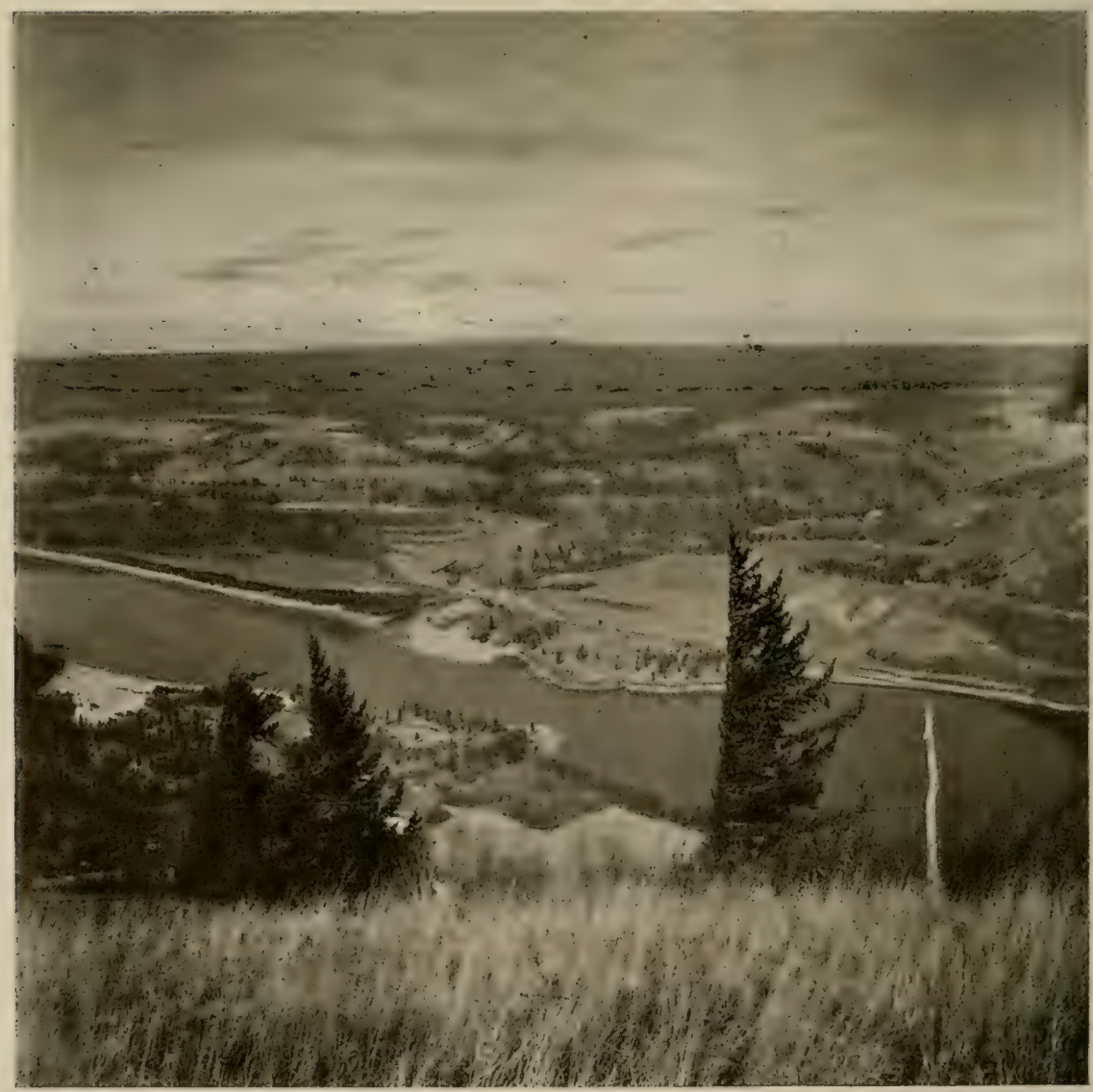

The Columbia River from the Mosier View Orchards. 


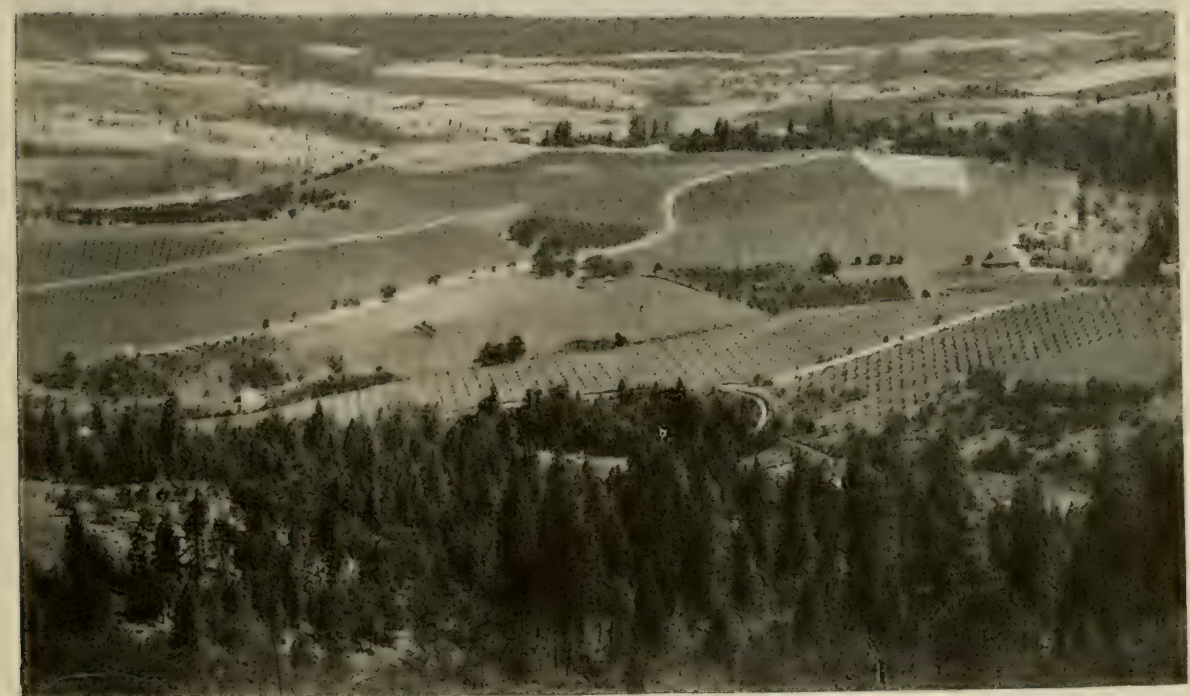

The Mosier Hills district, Oregon.

\section{The Process of Charpitting}

H. W. Sparks, Washington State College, Pullman.

About two years ago I commenced my duties as supervisor of farm demonstrations, this being a division of the farm extension work of the Washington State College. Later, in making a trip through the western part of the state to study its needs, I became interested in land-clearing problems, and thus was led to investigate everything which promised to aid in the solution of cheaper methods of clearing.

I think that many persons have noticed in "burnt over" areas, here and there a stump which had burned down into the ground. This was no accident. The roots were burned out because certain factors happened to be just right. When we learn what those factors are and duplicate them we also can burn a stump down into the ground.

Two years ago I learned of a man who had burned stumps, using what was locally ealled the "charcoal" method. I visited him, and sure enough, he was burning stumps. It seemed to be a very simple method. He put a little fuel around the stump, covered it over with a 
little soil, gave it a little attention every day and the stump was finally burned out, far down into the ground.

Having mastered his method, as soon as I could I went out on farm institute work and told others how to do the work by that method. Later, in coming back over the same route, I learned that many persons who had tried this method had failed. I was therefore concerned to know the cause of their failure. Upon investigation I learned that failure in some instances was due to differences in the soil, others to improper understanding of the method and so on.

It was encouraging, however, to find a few persons who had succeeded. We have been conducting experiments in different soils and with all the varied conditions and investigating the cause of failures. We now believe that many of the failures are due to soil conditions not being favorable; or if favorable, many of the operators "cover" too deeply. We have been conducting some experiments in sandy and gravelly soil and have found that stumps can be burned out in the worst red sand soil down two or three feet with reasonable certainty.

We remove a small portion of the surface soil next to the stump, then place the fuel in this shallow trench, covering it over with cinders or clay. With the same amount of care as is usually given, the stumps will burn out. By this method two of our operators fired 18 stumps in six hours, using a third man to haul the material to the ground. Of the 18, 15 were burning the next morning. Three had been put out by the rain.

We have tried many experiments that have been failures. When we first learned that the usual method would not work well in sandy soil we tried artificial coverings, such as sheet iron, but that was a failure. We next tried mixing in other materials with the sandy soil. We thought we needed a "soil binder" to hold the soil particles together, thus keeping them out of the fire. We tried lime, tar, and other things, which also failed.

We then discovered that the difference in soils was not due so much to texture as to other characteristics, which were, principally, the conductivity or non-conductivity of the soil. The heat generated under the soil covering must not be lost, but rather, should be conserved and concentrated on that part of the stump that is to be burned. The soil that lies loosely has many air spaces, making it a good nonconductor of heat. Most of our clay soils when subjected to the heat of fire, decompose sufficiently to become light and porous. They concentrate the heat and do not conduct it away. The reason that some soils had failed to do the work well was that under the influence of heat the soil particles had settled together, becoming natural con- 
ductors of heat, and thus conducting the heat away from the stumps. Also, the absence of adhesive properties makes it difficult to hold the soil up or prevent it from running into the fire.

There is another factor which we believe to be important. That is "radiated heat." A well-established rule of radiated heat is that the heat diminishes in intensity as the square of the distance from the radiating body increases. A body 10 feet from the fire will receive only one-hundredth part as much heat as a body one foot from the same fire. Radiated heat goes in straight lines, and the angle of reflection is always equal to the angle of incidence. That is, if it strikes the reflecting surface perpendicularly it is reflected perpendicularly, and if the line in which it approaches the surface forms an angle it glances off at an equal angle on the other side. It is this last factor that makes for better results when we keep our fuel down to the least amount necessary for a good start, and is in favor of concentrated fuel, such as fuel oil. The cover being flatter the reflected heat is returned to the burning stump lower down. And as wood is a natural absorbent of heat, this helps prepare for the burning.

Let us illustrate this a little farther. Many persons doubtless have noticed while traveling through the woods after a fire, that where one $\log$ had lain across another, or perhaps two logs had lain together for part of their length, burning had been more complete than at points where the logs had been farther apart. This was due to the radiation of heat from one $\log$ to another. An increase in the distance between the burning logs was marked by a decrease in the intensity of the fire.

All these points are factors in the work of charcoaling stumps. and if we understand them it helps us to arrive at definite results. There is no accident about it. By the application of these principles we reverse the natural tendency of fire to burn up, and cause it to burn down into the roots, as has been proved in our experiments with hundreds of stumps. There is enough of this work done in different parts of the State of Washington, and by different people, to prove conclusively that it is practical and no longer an experiment. Near Chehalis, Harry Thompson and myself fired 100 stumps. We tended them, and charged 25 cents an hour for the time we worked. The stumps were lemoved in this way for less than 40 cents each. Harry Yount, of Woodland, Wash., removed stumps for about 35 cents each. Mr. MeCormack, editor of the Woodland Echo, owns a stumpy field, that has been plowed for years in the same way, piling up the soil on the upper side (the field slopes westward and toward the prevailing wind), and plowing away from the lower side. He contracted to have the stumps removed for 50 cents each. The man who took 
the contract had some skill for the work and, perceiving the natural advantage of conditions, fired the stumps on the lower side only, resulting in his taking out the stumps for about 25 cents each. I could tell of dozens of men who have taken out stumps suecessfully by these methods.

The principal thing is to adapt the method to local conditions of soil and climate. I believe I am justified in saying that it is more difficult to burn during the season of extreme rainfall where soil is not well drained, and that the sandy or gravelly soil burns just as well, if not better, then, perhaps because the sand packs or bakes better around the roots when wet, and also because there is better draught in cooler weather. In our recent experiments we found sevcral roots not burned as deeply as they should have been in clay soil.

We have been experimenting with different fuels to find something cheap and practicable for use in place of the wood on the gromel for unfavorable seasons, and have found fuel oil very good. It costs but 90 cents a barrel if bought in quantities. This is the same fuel that is used by oil-burning locomotives, on steamboats, ete. We paicl three dollars per barrel in small lots (single barrels), and used from one to two gallons to each stump. IIaving previously prepared the stump by taking off the bark and digging away the surface soil about one foot out from the stump at the surface with the side of the trench sloping in toward the stump at the bottom, we first put in some sawdust; or in the absence of sawdust, used chips. small pieces of wood and bark, making good "kindling wood" of it. The kindling is necessary for the purpose of furnishing the necessary heat to ignite the oil, which, like coal, will not burn well until heated. We then pour the oil over the kindling, and with some wood and bark over the top to hold the covering up, we cover with clay, cinders or the soil around the stump, if fit for the purpose. We soon see the effect in the burning stump. Afterward, the care is about the same as with all methods. Keep the fire covered. We do not think it necessary to use the fuel oil in dry seasons, when we can gather the material that will burn well. During the wet season, however, when all the wood on the ground is wet, we think there is an advantage in some fuel of this kind. We must have a good start.

Recently we have made some experiments with the view of reducing the amount of fuel necessary to start. We selected stumps where two roots were located about the right distance apart for a fire betweeu them, and removing the bark, dug ont a small hole between them about one foot deep. Then we bored an auger hole with a small auger from the opposite side of each root, boring down and across the root so that the auger came out about half way down between the ground 
line and the bottom of the hole we had dug in between the roots. We next started a fire in the pit, using not more kindling and wood than would be used to make a fire in a heating stove. All could be carried easily with one armful. This we covered with soil and started the fire. After several hours when the fuel had burned down to a bed of coals we poured one pint of the fuel oil down each of the auger holes and covered it over lightly to prevent too strong a draught. We found the next day that the stmmps had been suceessfully fired. The advantage of the auger holes was that there was afforded the opportunity to supply the fire with concentrated fuel without disturbing the cover, and the auger holes furnished a vent through and under the wet sap wood, absorbing the heat and preparing the wood for the fire to follow.

Under favorable conditions, when we have a good clay soil and some good dry fuel at hand, it is not necessary to do any digging. Take away the bark and pile the fuel around the base of the stump. generally not more than 12 or 15 inches high, and about as wide at the bottom. Arrange some kindling around in under the wood to lead the fire. We fill in all small openings at the top of this wood with small pieces of chips, bark and rotten wet wood, or ferns, to prevent the soil from ruming between the stump and the fuel. Then we cover this with soil most conveniently at hand. leaving small space open on the side toward the wind so that when the fire is lighted in this opening, it will be blown into and under the fuel and covering When the fire is well under the cover, close this space also.

Now, what is the right amount of eovering? I do not know that it will be possible to lay down any hard and fast rule. Every operator must learn by experience. He must know something about the soil, experimenting to see how it works; and then he must know that it is necessary to have something under the cover besides fuel to make it "burn down"; that is, conditions must be such that there will be a supply of oxygen. The miner knows that in driving a tunnel, if the air is cooler outside than in the tunnel, the cold air will come in at the bottom and be warmed by coming in contact with the warmer material inside. Thus warmed, it becomes lighter inside, rises to the top, and the cold air coming in to fill the vacuum thus formed. starts a continuous flow in at the bottom and out at the top.

So when we put this covering over our fire we purposely leave open spaces at the bottom. The air comes in and moves up to the fire with its full store of oxygen: For this reason the fire is always hotter and burning best at the bottom. The air minus the oxygen becomes heated, moves upward, and filters through the eover with the gases, and as the burning proceeds into the stump, we must keep the 
fire covered; when the top is burned off, we cover all over lightly, just enough to conserve the heat, but not so heavily as to prevent a movement of air through it. Thre will always be some low point where the cold air enters, and the colder the outer air is the greater will be the expansion when the air comes in contact with the heat inside the cover. This condition stimulates the draught, causing: better burning.

There is one guide which is quite reliable. When the fire comes. through the covering, and hot, blue smoke issues forth, more cover is necessary. If the smoke is dense and white, this means that it is mostly steam and that the gases are escaping which is the correct condition.

\section{Questions and Answers.}

Q. Do you stand the wood on end?

A. We use the wood that we find at hand, using some of it long, which must be laid slanting or flat. In some places the short wood is set up on end, being easier to "fit" around the sharp angles of the protruding roots. However, we wish a fairly uniform amount of this fuel so that it will burn out evenly and the cover will settle down uniformly. I think it a good plan to place some kindling all the way around the stump to lead the fire. If we can start the fire on the inside we will always have the stump exposed to the radiated heat, and as the wood is an absorbent of heat, we are preparing for the burning by getting it hot.

I believe we will find it the better plan to fire our stumps in the morning, utilizing the afternoon in preparation. When fired in the morning our fires are well settled down before night, thus lessening. the danger of a break in the covering during the night, which would let all the heat escape. The first 24 hours is the most critical time. We usually go over our work with a lantern just before quitting for the night, and are out again early in the morning. This work is not hard, but rather exacting. We should give regular attention to it.

Q. How long does it take a stump to burn out?

A. The time varies. A stump will burn out quite completely in: five or six days in some cases, and again, another stump will take as many weeks. I think the difference is due in part to depth of cover, condition and size of the stump.

Q. Have you burned any of the hardwood stumps?

A. We have not had much experience with them. Have fired hemlock successfully, however. I think I will tell you of a hemlock stump which has resisted several attempts to fire it. I secured some 
thirty-penny spikes, and selecting spots where the wood was best exposed to the fire, drove in a group of fire or six spikes in each spot, which was not larger than your hand. The heads of the spikes I left sticking out about an inch. Then I built my fires around and under, so that as the fire burned these spikes, the part of them exposed to the fire became heated. Iron being a good conductor of heat, the heat was conducted into the wood. The result was satisfactory, for the stump was fired.

Q. How small a stump is practicable?

A. In our experimental work we have thought that anything less than 15 inches in diameter had better be moved with a little powder or by horsepower, and sometimes a combination of both.

Q. In clay soils, is it necessary to have a trench?

A. It is not necessary, but in extremely wet conditions, a little surer, since if the stump is fired down lower, it is more likely to burn deeper.

Q. Do you get the roots out?

A. Yes. The fire works right down into the roots, and will do the work as thorough as any other method. Most of you know there are some roots left when you start the plow after any method of stump destruction.

Q. In starting the fire, should it be started in more than one place?

A. We have started in one place only, but think on large stumps two fires from opposite sides of the stumps would make for quicker results.

Q. Should the fire be started on the side from which the wind blows?

A. Yes. Start the fire so that the wind will blow the fire toward the stump, thus driving it under the cover sooner. The fire will then follow around under the cover.

Q. In sandy soil, should the clay be put over the wood as the fire burns it, or should it all be covered up?

A. Cover this starting fire right up to the stump before firing. Never cover the top of the stump until the fire eats its way in. Keep the fire covered.

Q. Is the same covering used for different soils?

A. Yes. Use just the same for clay as for sandy soils. In sandy soils we must use the artificial covering. We have found coal cinders just as good as clay. Naturally we will use the covering that does the work best and is most convenient.

Q. How long should the space where we start the fire be left open? 
A. Until the fire is well started. Fifteen minutes to half an hour is usually enough.

Q. Does the top of the stump fall over?

A. Yes, very rarely the top is burned up.

Q. How about burning a green stump?

A. We have not had very much experience with green stumps, but have been told by those who have tried it that they burned very well when started. They are said to be a little more difficult to start. Chop through the sap wood in a few places.

Q. When the top burns off, what follows?

A. Always keep the fire covered. I think it is necessary after the first $2+$ hour's to visit the stump each morning and night, dividing the time as nearly even as you can. Especially, go early in the morning. Tsually the fire will huru better at night than during the day. This is because the air is colder. and upon being warmed as it passes in to the fire, a stronger draught is created than if the outer air were warm. There are therefore liable to be holes in the covering which should be given attention early in the morning.

Q. How old should stumps be to burn best?

A. We have burned them off all the way from 1 to 50 years after cutting.

Q. Do they burn better after they are dry?

A. Yes, it is easier to fire them when they are dry, hence it is easier to fire them in the dry seasons. I have successfully fired stumps over 50 years old which were remnants of old burns before. the logging-off cra. With some of these there were 6 to 12 inches of rotten wood on the outside which was so wet that water could be squeezed out by hand. We chopped through this in places, giving the fire a chance at the sound wood underneath.

Q. Must the bark invariably be taken off?

A. Yes. Usually it is very easy, but if it sticks, as it sometimes does on new stumps, it must be chopped away. Bark is a non-conductor of heat and full of air cells, and is made so by nature to protect the growing wood against the extremes of temperature.

Q. How high should the bark be removed?

A. Twelve to 15 inches will be sufficient.

Q. After the stumps are fired, how many can one man care for?

A. I have gone over 100 in half an hour. Sometimes it may take longer. Usually not much is to be done when the fire is starter in properly. A shovelful over the fire here and there, pushing a little of the cover over the fire where it begins to show ahead of the cover, is the usual procedure. W. H. Booth, of Supena, Wash., burned out 603 stumps in nine weelss with the aid of two boys. 
Q. How would you keep the soil from falling into the fire for several days?

A. Arrange the material so that it will not burn out in spots, or rather, so that it will burn evenly, settling with the cover all together. If this cannot be done, perhaps your soil is too sandy and inclined to run into the small openings when it gets hot.

Q. I have about 300 stumps burning, but when the top falls, they stop burning.

A. You probably have not followed your fire up closely enough with the cover, or possibly have covered too deeply.

Q. Would there be any advantage in wire netting?

A. I think not. I would not want to use anything of that kind, because $I$ think it too rigid. We want this cover to be self-adjusting and loose, so it will follow up the fire.

Q. In case one bores a hole, should it be covered?

A. I would place something over it, but do not close it entirely.

Q. Will clay soil be left in clinkers?

A. There will be some in places, but not enough to do any material damage.

Q. Would there be any advantage in using kerosene?

A. Kerosene can be used for a starter, but it does not last. The fnel oil we use has about twice as much fixed carbon as the best anthracite coal. It burns slowly and steadily.

Q. Have you ever tried charpitting in the red shot soil?

A. Yes. I think it is all right. Most of the shot elay soils work well.

Q. One would not have to have clay soil to work the process, would he?

A. No, not in the shot elay. 


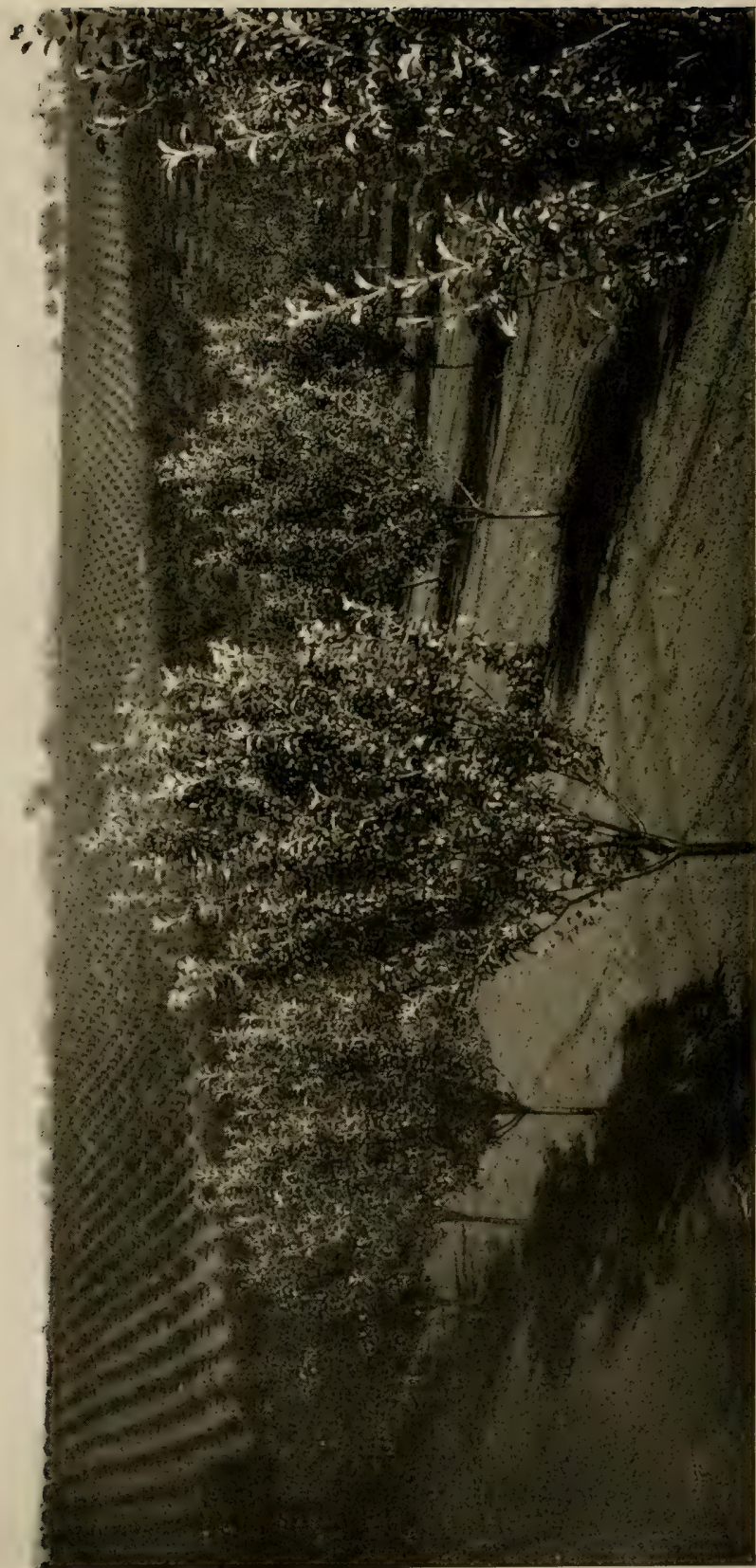

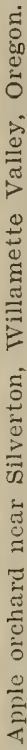




\title{
The Small Farm and How to Make it Pay
}

\author{
By Dr. James Withycombe, Director of the Experiment Station,
} Oregon Agricultural College. Q purpose tonight is to speak about the possibilities of a small
farm. Oregon agriculture will be ultimately characterized by its small farms, intensively cultivated. This is due to a hospitable climate and a potential soil, readily responsive to intelligent methods of husbandry. The state, as a whole, and more especially some sections, enjoy a very wide range of crop production. This of itself makes it highly adaptable for the small, but prosperous rural home.

Economic production means prosperity. Thus when a few acres of soil are made to yield abundantly it brings comfort and contentment to the owner. Under more intensive culture, which should be the logical accompaniment of the small farm, agricultural production would be greatly augmented. This will mean not only prosperity for the individual, but the community as well.

All wealth practically originates in the soil, thus greater attention should be given to soil conservation and the problems of crop production. Since our national wealth is so closely related to successful agriculture, it would seem that greater effort should be made to acquaint a larger proportion of our population with the fundamental, or at least elementary, prineiples of erop production. Agrieulture should be more generally taught in the public schools of the state. It is a mistaken idea that this branch of instruction is suited for the country boy only. The eity boys should know something of the farm and the problems of rural life. Often by reason of health and inclination they desire to engage in some branch of husbandry, but are precluded on aceount of a total lack of knowledge of the most simple things pertaining to the farm. "Back to the soil" is a popular slogan, but it is dangerous to heed without some preparation to cope with rural conditions. The work of this association is greatly to be commended inasumch as it has not overlooked the importance of the farm in its great scheme of industrial education.

There is another unocenpied field for agrienltural instruction of an intensely practical type. This is a field worthy the consideration of the philanthropists. For example, a large body of land suitable for small farm homes may be secured and upon this departments of dairying, poultry husbandry, oreharding, truck gardening, and general 
farming be maintained; the labor to be performed by young men from the city who desire to take up life upon the farm; these men to receive a wage and board for their work with the understanding that they may secure ten or twenty acres for a home when they are ready to meet certain definite requirements which should be within the reach of any industrious, frugal young man. Such a farm, under a proper system, should be self-supporting and intensely educational in a practical way. It requires greater skill to successfully manage a small farm than it does a reasonably large one. Thus it is imperative that hefore a city young man undertakes to farm for himself, he should have some practical knowledge of the industry.

The state has been wisely committed to the policy of supporting demonstration farms and experiment stations for which provision has already been made for the support of six. It would be well, however, whenever practical, for high schools to be established within easy reach of those farms in which work in agriculture is given. These farms would then have the dual purpose of demonstrating to the farmer correct systems of husbandry and be a potent source of inspiration and education to the high school student. So far as possible the state and county should co-operate in this work. Nothing will improve a rural community more quickly in a financial and social way than a general dissemination of correct information relating to agriculture. Technical knowledge is power only when it becomes dirfused through industrial activities.

Oregon is a magnificent state, rich in opportunities and possibilities. At present. however, there is grave danger of over-production in some directions. The virtues of much land are extolled for certain specific productions which really are of questionable adaptability. This is a serious mistake, and the reaction that in many cases will inevita!ly follow will be harmful to the hest interests of the state. r'he purpose of this address, however. is to emphasize the small farm. As before stated, Oregon is destined to be the home of the small farmer. Ten acres will perhaps be the smallest unit for some time. This even appears as a very small farm to many. Rightly managed. ten acres of good trpical land in the humid or irrigated sections of the state can be made to yield a good living for a family. It may be hazardous, however, for one to undertake to make a living upon ten acres of land without a well-grounded knowledge of local conditions. A larger unit would be better so that mistakes which are liable to oceur would not bring such financial disaster. Upon a small farm a single mistake, or the failure of a single erop, may affect seriously the total income. The success of any farm, whether it be large or small, will depend largely upon the personal equation of the 
owner or the one in charge. Some men will make a phenomenal success of the small farm while many others will make dismal failures. It is doubtful if a single crop production will prove successful. but a little of several things coming in rotation, or products that bring in a constant revenue are better than the ordinary one-crof) system. A few cows, poultry, and some fruit and vegetables should receive the attention of the small farmers. Not only is the constant revenue from this system an advantage, but it also affords continuous employment and the cows and poultry will supply much valuahls? plant food for the different crops. It is especially important that thr soil of a small farm be kept in a high state of fertility.

A spirit of co-operation should be prevalent in a small-farm community. This is especially necessary in team work. Each small farmer should have one good general purpose horse, which can do all the work except plowing and general preparation of the soil for crops. When plowing is to be done, it should be well done, and this requires at least a team of horses. It should he arranged to have the neighbor's horse assist in this work. There will be many instances where co-operation will be highly desirable. The investment in a high-class dairy sire should be under community co-operation. This same principle should enter largely into the general distribution of crops. Organization and co-operation is the very life blood of a successful rural community. Without this it is doubtful if the small farmer can possibly reach the highest attainment in civilization and wealth. Cooperation in social and intellectual affairs is highly important, in fact. this spirit should thoroughly permeate every rural activity.

The class of farming undertaken should be largely governed by soil adaptability and local market conditions, although a few cows and some poultry are practically indispensable for success. It is not to be expected that all of the feed for the poultry and other livestock is to be grown upon the farm. The grain and mill feed should the purchased, but this must be judiciously fed and fed only to stock that will give maximum returns for food consumed. The farm must also be made to produce the largest possible crops. Soiling must be practiced for the corvs and all by-products carefully conserved and utilized. The small farm must be made to grow steadily richer rather than poorer. It is a good maxim to follow upon the farm to keep nothing in the form of livestock but what is growing in value or vielding a revenue in service or production. The hens must be young and vigorous, and the cows not old and declining.

It is impracticable to establish any definite rules for conducting the small farm. Systems must be worked out to meet local market conditions, adaptability of soil and other problems of interest must be 


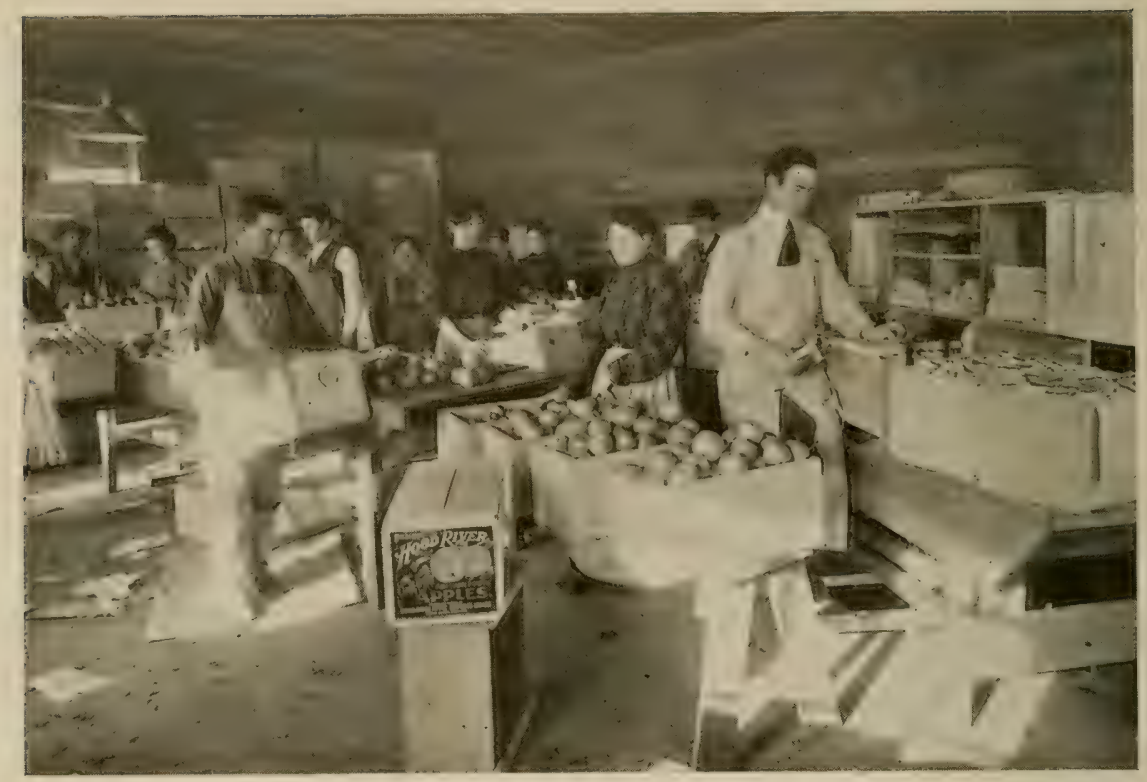

Interior of a Hood River apple packing house.

considered. In a general way one acre should be utilized for the buildings, lawn and home garden; four acres should be devoted to the growing of hay for the livestock. For Western Oregon conditions this hay should be mainly clover. Four acres of good clover should yield 15 tons of hay and furnish one month's pasture. One acre of tree fruits, comprising early fall and winter varieties of apples, Bartlett and winter pears. If the land is sandy, peaches may also be included. One acre of small fruits and vegetables; one acre of potatoes, two acres for growing summer forage and winter succulent feed for the cows. One acre of this should be planted to corn to be fed green after the clover pasture is done. The remaining acre should be planted one-half to kale and a fourth to mangels and a fourth to winter rye and vetch for early spring cutting. This series of crops should furnish, miler good cultural methods, sufficient green feed and hay for four cows and one horse for one year.

The gross returns from this system of farming should be approximately as follows:

Butter fat, 1,100 pounds at 32e per pound, $\$ 352$; 24,000 pounds of skim milk at $30 \mathrm{e}$ per hundredreight, $\$ 72$. This is estimating the food value for poultry. hogs or calves. Eggs from 200 hens, 2,000 dozen at $28 \mathrm{c}$ per dozen, $\$ 560$; potatoes, $\$ 100$; fruit, $\$ 250$; vegetables, $\$ 75$; total gross income, $\$ 1,409$. 
Expenditures-Feed for poultry, $\$ 200 ; 5 \frac{1}{2}$ tons of grain and mill feed for horse and cows at $\$ 28$ per ton, $\$ 154$; four tons of straw at $\$ 5$ per ton, $\$ 20$. Total cost of feed and bedding, $\$ 374$; thus leaving a halance on the right side of the ledger of $\$ 1,035$. From this, of course, should be dedueted the cost of seed, depreciation in value of horse and enws, spray material, repairs to buildings and fences, blacksmithing, interest upon the investment, taxes, etc., which would aggregate about $\$ 165$. This would leave a net balance of $\$ 870$. It is understood that the owner and his family does all of the labor on the farm. This is not a large income, but indicates that a good living may be made upon ten acres of land when well managed. The cost of living upon a small farm will be appreciably less than in the city. Wood will cost less, water is free, and the home garden will supply all the vegetables for the family.

It should be definitely understood at the outset, however, that the smaller the farm unit the greater skill is required for its successful operation. Also that single-crop production, as a general rule, is not the best system to follow upon a small acreage. This, of course, will depend more or less upon local conditions. For example; If the land is peculiarly adapted for such special crops as onions, horseradish, asparagus, or celery, it may be advisable to make the growing of these a specialty. The one great objection, however, to these special crops is the want of general distribution of labor requirements upon the farm. Systems that require more or less constant labor are better. This also insures, as before stated, a steady return. The income should be constant from month to month upon the small farm.

The small farm community has many advantages over more sparsely settled agricultural districts. Social opportunities are much better. The problem of good roads is more easily solved. Country life under such conditions more nearly represents urban life. It combines the opportunity to enjoy the health and vigor of rural life and the social and educational advantages of the city. The small farm is destined to solve the problems of country life. It is here we shall find our sturdy, intelligent and patriotic citizenship.

\section{Questions and Answers.}

Q. How about irrigation for your ten acres?

A. These clay soils are hard to handle with irrigation. Voleanic ash soils are all right for irrigation.

Q. Is there not some soil west of Roseburg that is rather poor?

A. Up there in the hills the soil is all right and can stand irrigation. 
Q. On ten acres one would need a team of horses and have four cows to pasture?

A. Turn the cows on your pasture about a month each year, then feed them on your kale and buy your mill feed.

Q. What do you estimate the returns on ten acres?

A. I think about $\$ 1,500$. There will be about $\$ 550$ for expenses. which should leave about $\$ 950$ net.

Q. Does a cow need range?

A. If you have a lot, that is all that is necessary. At the college we have cows that have not been pastured for five years.

Q. What would one raise for ehickens?

A. I would not raise feed for chickens. One gets so much plant food from the poultry to keep up the land, he can afford to purchase the feed. If one has poultry of the Mediterranean breeds, they will lay at least ten dozen eggs per hen, and average 2,000 dozen eggs. At the average price of 26 and 28 cents per dozen in this market, this would amount to over $\$ 500$.

Q. Would not apples bring a good deal more?

A. They may some years, but when frosts come as sometimes happens there will be no apples.

Q. Mr. Mason, of IIood River, stated here that his average for five years was $\$ 500$ per acre.

A. I would not start on that kind of a proposition. That record was made under exceptional conditions.

Q. Can alfalfa be raised on red shot soil?

A. One must test his land. Alfalfa will not grow on acid soil. One can correct the acid with lime, and then it will be all right. One would be surprised at the amount of alfalfa that can be grown here in the valley on unirrigated land. We cut the crop four times.

Q. Doesn't alfalfa exhaust the soil very rapidly?

A. It does if one sells his alfalfa. If he feeds it to his cows, it loes not exhaust it. It takes a good deal of potash, phosphate and lime.

Q. Is air-slaked lime of value to the soil?

A. It is the only means of correcting acid.

Q. How much should one use to the acre?

A. About 500 pounds. Lime is not needed except for special crops.

Q. Do you consider it of any value for fruits?

A. I am not a horticulturist and cannot say, but I should not think it would do any harm.

Q. Will red-shot soil grow sweet potatoes?

A. I think it is too far north up here. 
Q. You haven't said anything about the hog.

A. Hogs are all right, but I would not want too many on the farm. Hogs are to go more with grain farms on a large scale. Poultry will consume your food more profitably than hogs. Depend on the cow. Of course I am a cow man and see things through a cow specialist's eyes, but I know that the cow produces $\$ 14,000,000$ worth of wealth in Oregon.

Q. Would you separate for four cows?

A. Yes, unless you sell the milk to a condensary, but as a rule it pays better to sell butter fat rather than milk.

Q. What valuation of the ten acres are you figuring on?

A. I am figuring on about $\$ 1,500$. About $\$ 500$ in a house and $\$ 200$ in a barn for four cows and the horse. An able-bodied man ean build a pretty nice cottage for $\$ 500$ or $\$ 600$.

Q. Don't you think it would be profitable on a small place to raise a few hogs for a person's own use?

A. That would be all right, but it is better to sell the hog and buy your own meat. There is great waste in butchering hogs in the country. Since the country has gotten so settled up there is opportunity to get fresh meat all the time. Two great packers are getting rich out of the by-products. They have been able to save everything but the squeal.

Q. What would be the cost of cows, etc.?

A. The cows would cost about $\$ 50$; chickens about $\$ 1$ each. Cows are good for about 12 years. Hens should be replaced every year. A horse is good for 20 years.

Q. What would be the necessary investment on a ten-acre farm?

A. About $\$ 125$ per acre for the land, $\$ 750$ for the buildings, and then the cost of your stock, making a total of about $\$ 3,000$. Roughly speaking, this starts one nicely so he can make a good living.

Q. Do you advocate keeping bees?

A. Yes, a few stands of bees are all right.

Q. Would you consider Guernsey-Jersey good for butter fat production?

A. I would not cross the breeds.

Q. How is Jersey-Durham?

A. That is trying to produce beef and milk. I would grade up the Jersey.

Q. What breed of chickens do you recommend?

A. The laying breeds, such as the Minoreas or Leghorns.

Q. What vegetables would you plant?

A. That would depend upon your market conditions.

Q. How do loganberries do? 


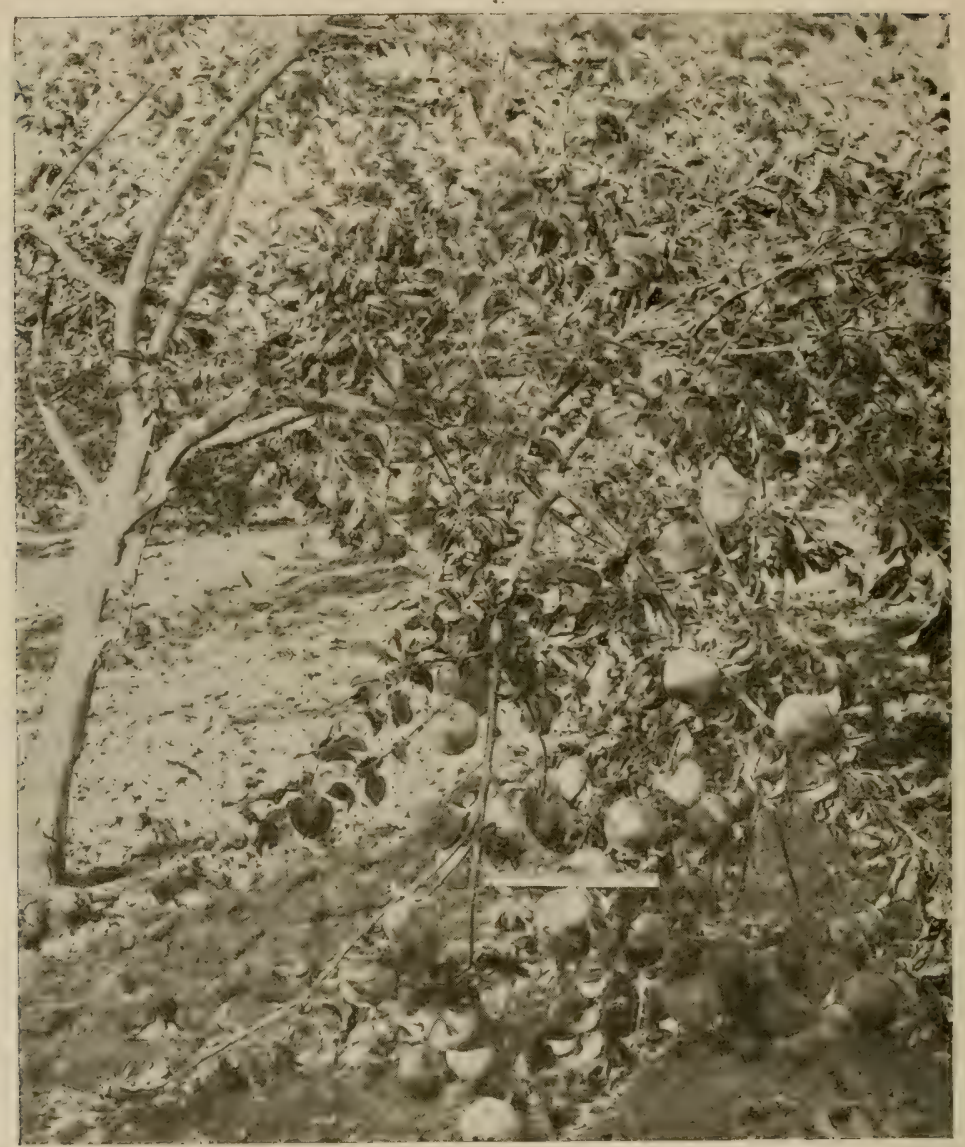

Branch of apules from Pullman, Washington.

A. They do remarkably well and bring good returns. They are going to grow in popularity. A fruit juice is being made from the loganberry that is very popular.

Q. How about tomatoes?

A. This is not a tomato country. We cannot compete with the warmer sections. The nights are too cold.

Q. How about celery?

A. Celery is all right.

Q. Would you tile land?

A. The greater portion of the Willamette Valley land should be tiled. Land should be tiled three and one-half feet deep and 150 to 250 feet apart. Nost of the Washington County farms are tile drainer. These tiles average about 300 feet apart.

Q. Would you use a silo? 
A. I would not use a silo in Western Oregon. I would recommend kale instead. A silo is too expensive to maintain on a sman farm. One ton of kale is worth two tons of silage.

Q. Does kale exhaust the soil?

A. Yes, but the cow will put it back again. She fattens the ground.

Q. Would you recommend buying day-old chicks?

A. That is all right. It is quite an industry in California, but be sure to get stock that you can depend on.

Q. Does the college sell them?

A. We do not sell them. Prof. Dryden is working a plan of setting four hens, and when the chicks come off, they are given to two of the hens and the other two are put back to lay again.

Q. How do you apply the droppings from the hens?

A. Just mix them with soil and sow that broadcast over the ground. Use about half and half of soil and droppings. Fifty hens will fertiiize an acre of orchard.

Q. Do you set the kale plants out?

A. Sow them like cabbage, then set them out three feet apart. They will stand a temperature anywhere from ten above zero.

Q. Don't these tile drains soon fill up.

A. No, they remain open indefinitely.

Q. There is some of the white land that does not seem to produce much?

A. All that it needs is drainage. There is no land in the valley that will require eloser than 150 -foot tiling.








(15)

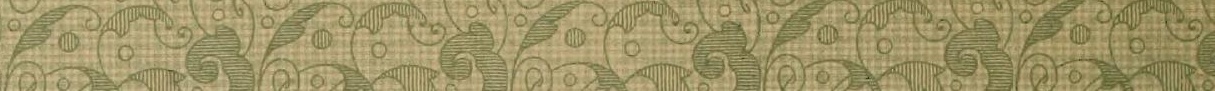

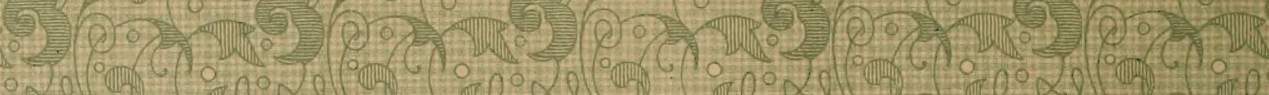
(1)

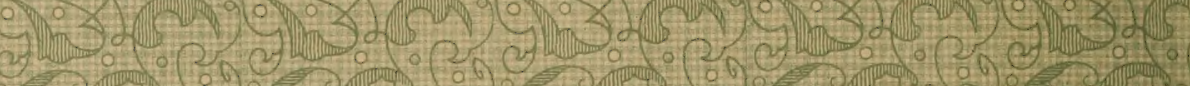

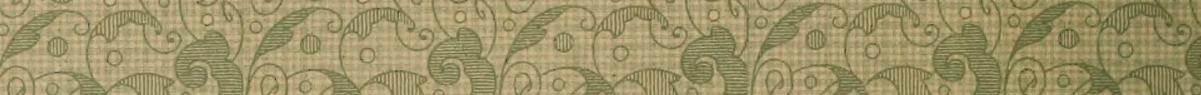

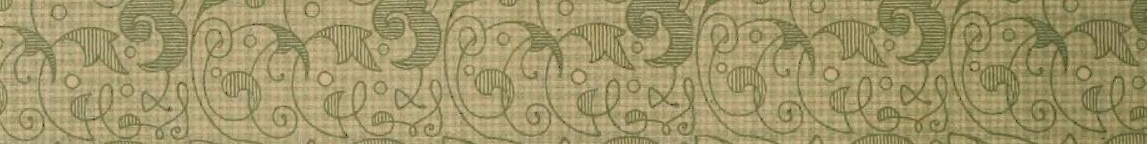
Pa (a) J

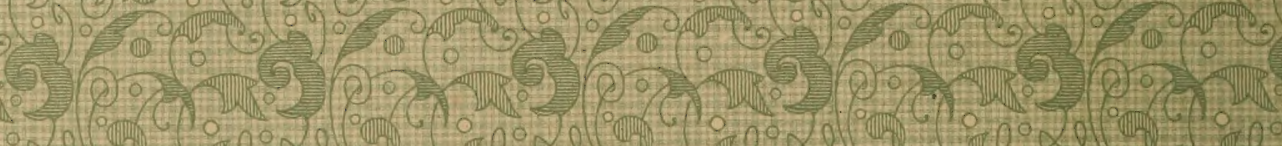



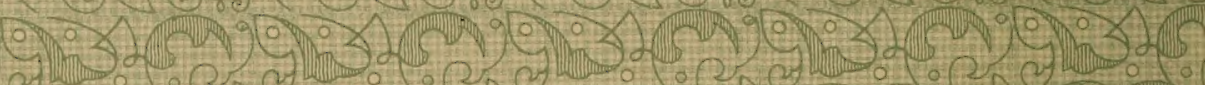

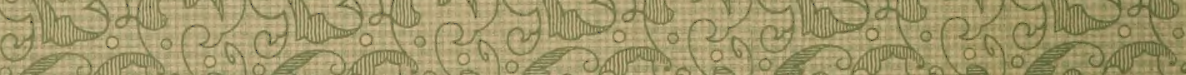

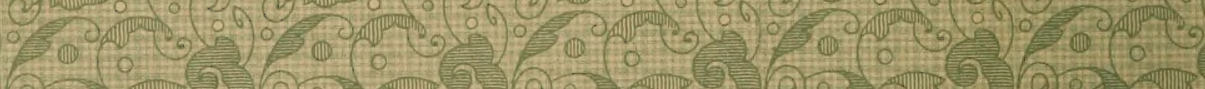

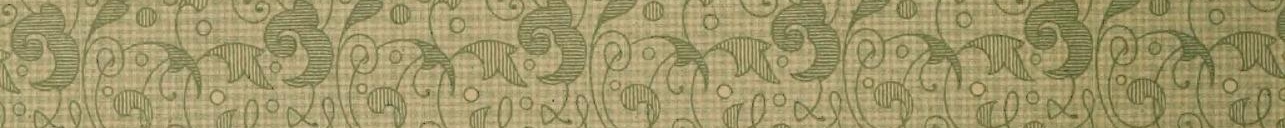

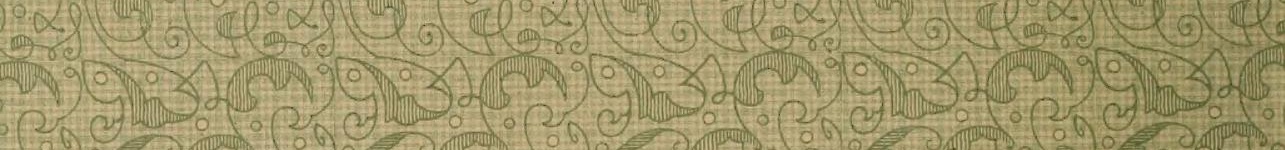

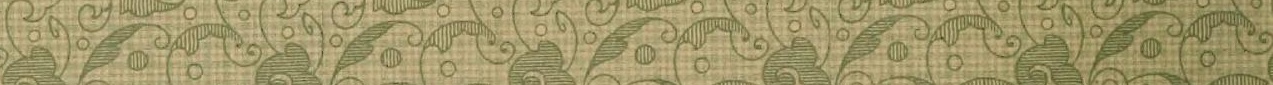

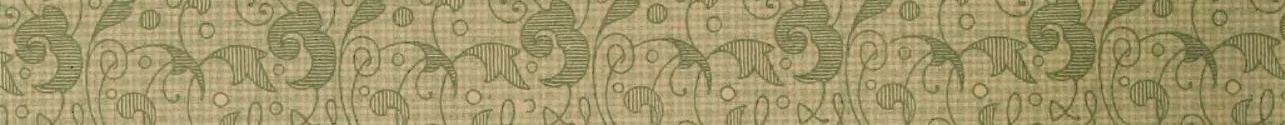

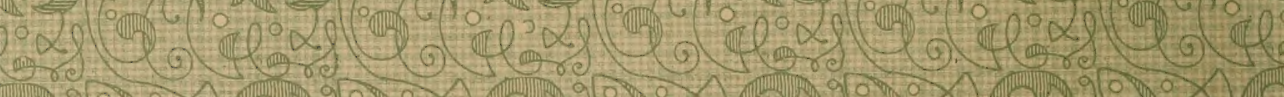

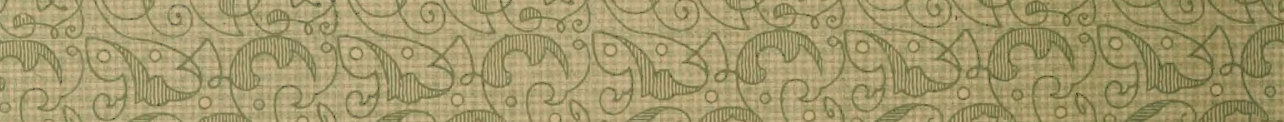


6.

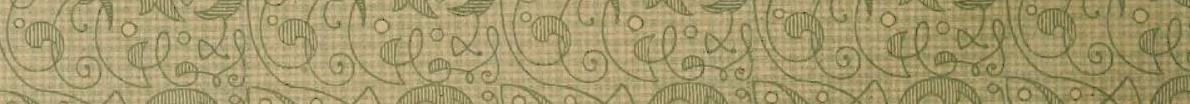

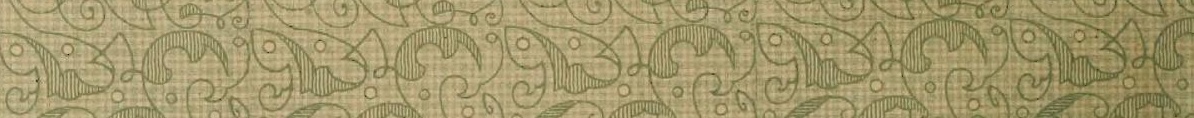
(9)

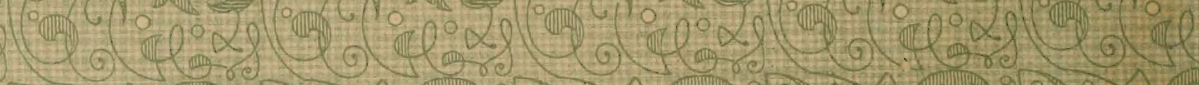

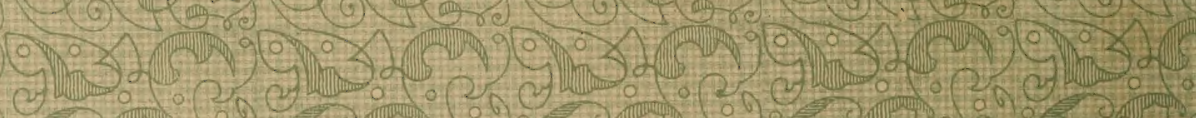

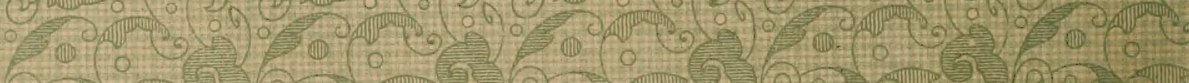

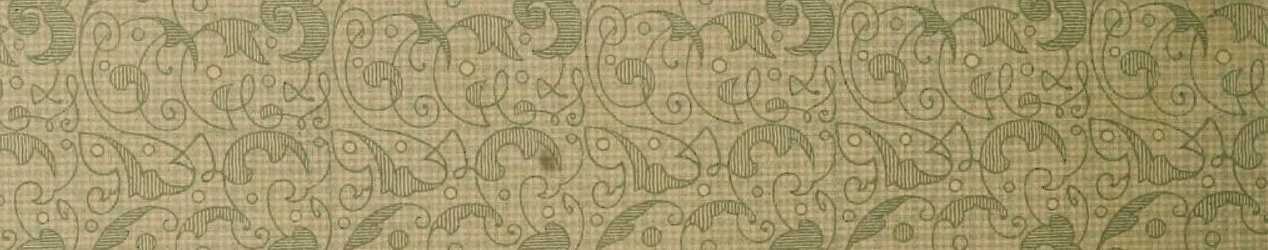





\section{LIBRARY OF CONGR}

|||||||||||||||||||||||||||||||||||||||||||||||||

00023378760 